\title{
An Economic Comparison of Sludge Irradiation and Alternative Methods of Municipal Sludge Treatment
}

by

S. B. Ahlstrom

H. E. McGuire

November 1977

Prepared for the

U.S. Department of Energy

under Contract EY-76-C-06-1830 


\title{
NOTICE
}

This report was prepared as an account of work sponsored by the United States Government. Neither the United States nor the Department of Energy, nor any of their employees, nor any of their contractors, subcontractors, or their employees, makes any warranty, express or implied, or assumes any legal liability or responsibility for the accuracy, completeness or usefulness of any information, apparatus, product or process disclosed, or represents that its use would not infringe privately owned rights.

The views, opinions and conclusions contained in this report are those of the contractor and do not necessarily represent those of the United States Government or the United States Department of Energy:

\author{
PACIFIC NORTHWIEST LABORATORY \\ operated by \\ BATTELLE \\ for the \\ UNITED STATES DEPARTMENT OF ENERGY \\ Under Contract EY-76-C-06-1830
}

Printed in the United States of America

Available from

National Technical Information Service

United States Department of Commerce

5285 Port Royal Road

Springfield, Virginia 22151

Price: Printed Copys__: Microfiche $\$ 3,00$

NTIS

$\begin{array}{cc}\text { *Pages } & \text { Selling Price } \\ 001-025 & \$ 4.50 \\ 026-050 & \$ 5.00 \\ 051-075 & \$ 5.50 \\ 076-100 & 56.00 \\ 101-125 & \$ 6.50 \\ 126-150 & 57.00 \\ 151-175 & 57.75 \\ 176-200 & \$ 8.50 \\ 201-225 & \$ 8.75 \\ 226-250 & 59.00 \\ 251-275 & 510.00 \\ 276-300 & 510.25\end{array}$


PNI -2431

IIC -23

AN ECONOMIC COMPARISON OF SLUDGE IRRADIATION AND ALTERNAT IVE METHODS OF MUNIC IPAL.

SLUDGE TREATMENT

by

S.B. Ahlstrom

H.E. McGuire

November 1977

BATTELLE

PACIFIC NORTHWEST LABORATORIES

RICHLAND, WASHINGTON 99352 


\section{SUMMARY}

One method to handle the increasing volume of sludge produced in the United States is through beneficial reuse (e.g. as a soil conditioner). However, sludge should not be reused unless it is made safe for those who may come into contact with it. For example, pathogens must be inactivated and toxic materials must be removed from the sludge. One method to minimize the pathogen level is through radiation treatment. This study reports the relative economics of radiation treatment and other sludge treatment processes. The desirability of radiation treatment is assessed in terms of cost and the quality of the treated sludge product.

The major conclusions of this study are as follows:

- Radiation treatment is a high-level disinfection process. Therefore, it should only be considered if high levels of disinfection are required for widespread reuse of the sludge.

- The handling, transporting and pathogen growback problems associated with disinfected wet sludge makes it less attractive for reuse than dry sludge.

- Radiation of composted sludge produces a product of similar quality at less cost than any thermal treatment and/or flash drying treatment option for situations where a high degree of disinfection is required.

- Heavy metal concerns, especially cadmium, may limit the reuse of sludge despite high disinfection levels.

It is recommended that radiation treatment of sludge, particularly dry sludge, continue to be studied. A sensitivity analysis investigating the optimal conditions under which sludge irradiation operates should be instigated. Furthermore, costs of adding sludge irradiation to existing sludge treatment schemes should be determined. In order to assess the use-potential of radiation treatment, a scenario should be prepared accounting for land use parameters, regulations, and existing treatment methods. 
$\checkmark$ 


\section{CONTENTS}

SUMMARY.

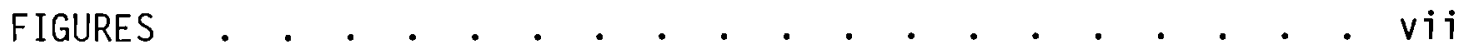

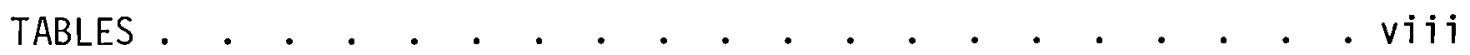

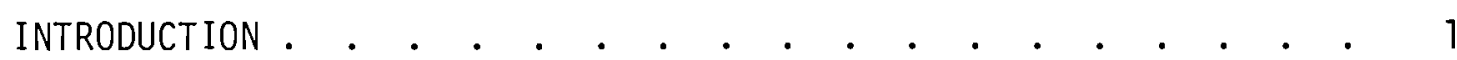

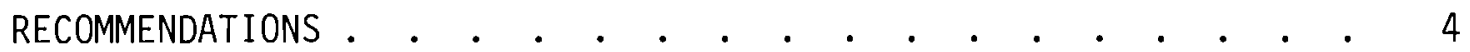

COSTS FOR SLUDGE TREATMENT AND DISPOSAL • • • • • • • • •

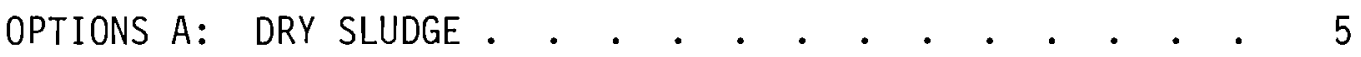

OPTIONS B: MOIST OR DEWATERED SLUDGE . . . . . . . . . 5

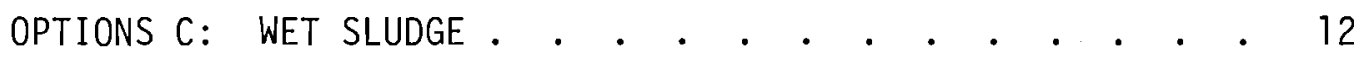

SUMMARY . . . . . . . . . . . . . . . . . . . . 16

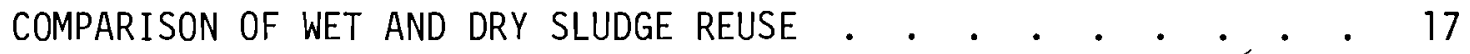

TRANSPORT COSTS . . . . . . . . . . . . . . . . . 17

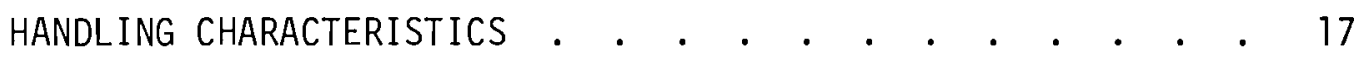

PATHOGEN GROWBACK. • . . . . . . . . . . . . . 19

SUMMARY . . • . . . . . . . . . . . . . . . . . . 19

COMPARISON OF PROCESSES PRODUCING A DRY, DISINFECTED PRODUCT . . 20

EVALUATION OF THE TREATED SLUDGE PRODUCT. • • • • • • • • . 22

DISINFECTION

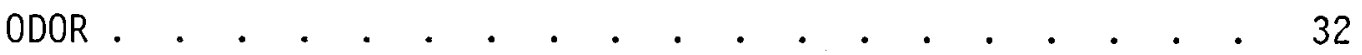

HEAVY METAL AND SLUDGE REUSE. • • • • • • • • • • • • • 35

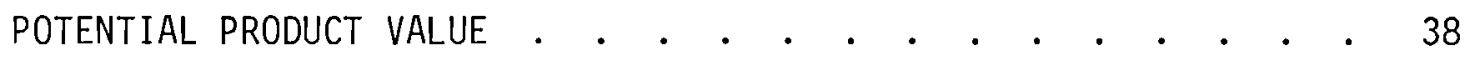

RADIATION TREATMENT COSTS AND BENEFITS . . . . . . . . . . . 41

REFERENCES. • . . . . . . . . . . . . . . . . . . . Ref-1 
APPENDIX A: TECHNICAL DESCRIPTIONS OF MUNICIPAL SLUDGE TREATMENT PROCESSES . . . . . . . . . . . . . . . . A-1

APPENDIX B: COST DEVELOPMENT AND DESIGN CRITERIA FOR UNIT PROCESSES USED IN MUNICIPAL SLUDGE TREATMENT . . . B-1 


\section{FIGURES}

1 Options A: Dry Sludge Treatment Schemes. . . . . . . 6

2 Dry Sludge Treatment Costs . . . . . . . . . . . 8

3 Options B: Mo ist Sludge Treatment Schemes . . . . . . . 9

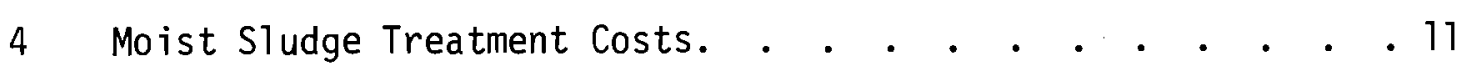

5 Options C: Wet Sludge Treatment Schemes. . . . . . . . 13

6 Wet Sludge Treatment Costs . . . . . . . . . . 15

7 Cost of Transporting Sludge by Truck from a 100 mgd P1ant . . 18

8 Costs of Heat Treatment and Irradiation Processes. • . . . 21

9 Historical Sludge Sales Prices (1960-1975) . . . . . . . 40 
1 Characteristics and Quantities of Municipal Sludges

Produced by Various Treatment Processes. . . . . . . 2

2 Dry Sludge Treatment Costs . . . . . . . . . . . 7

3 Moist Sludge Treatment Costs . . . . . . . . . .10

4 Wet Sludge Treatment Costs . . . . . . . . . . .14

5 Pathogenic Organisms Which Can Potentially be Transmitted by water, Sewage, and Sludge . . . . . . . . .23

6 Disinfection Ability of Some Sludge Treatment Processes .28

7 Temperature and Time for Pathogen Destruction in Sludges . . . . . . . . . . . . . . . . .

8 Bacteria Concentrations in Static-Pile Composted Raw and Digested Sludge $(c e 11 \mathrm{~s} / \mathrm{g})$. . . . . . . . . . . .

9 Effectiveness of Sludge Irradiation for Bacteria Inactivation. . . . . . . . . . . . . . . 32

10 Odor Effects of Sludge Treatment Alternatives. . . . . .33

11 Average Concentrations of Metal in Raw Sludge and Digested Sludge. . . . . . . . . . . . . . . .

12 Comparison of Amounts of Trace Elements in Wastewater Sludges and Soils. . . . . . . . . . . . . . . . . .

13 Assumed Prices for Fertilizer Nutrients, Approximately 1976 Dollars.

14 Value of Nutrients in 1 Ton of Dry Sewage Sludge Assuming Various Nutrient Contents and Commericial Fertilizer Prices. 


\section{INTRODUCTION}

Wastewater sludge is the semi-solid mass removed during the treatment of a wastewater stream. The characteristics and quantities of sludge vary significantly depending on origin, the degree of storage that has taken place, and the method used for treating the wastewater. Table 1 identifies the characterisitcs and quantities of municipal sludge produced by various wastewater treatment processes. An estimated 5 million dry tons of sludge are collected annually in the United States. Since all sewage treatment plants are required to produce a cleaner effluent, this volume will increase substantially in the near future. The problem of disposing of such a large volume of waste material has lead personnel involved with wastewater treatment to no longer consider sludge as just a waste product, but also as a possible resource.

There are many schemes for treating sewage sludges. However, the reclamation of sludge requires that the end product be environmentally safe and socially acceptable. For the past several years, Sandia Laboratories, located in Albuquerque, New Mexico, has been examining the use of gamma radiation to inactivate pathogens in sewage sludge. Cesium-137, a waste radioisotope from the nuclear power industry, is used to disinfect the sludge. This pathogen-free sludge would minimize the concern of disease transfer through sludge reuse thereby making the product acceptable for a wider range of application.

The objective of this study was to compare the economics of sludge irradiation with alternative forms of sludge treatment. The work reported in this text was sponsored by the Department of Energy through the Isotope Utilization Program, in cooperation with the Sandia Program. 


\section{TABLE 1. Characteristics and Quantities of Municipal Sludges Produced by Various Treatment Processes}

\begin{tabular}{|c|c|c|c|}
\hline Sludge Type & $\begin{array}{l}\text { Pounds Dry Solids } \\
\text { per Miltion Gallons }\end{array}$ & $\begin{array}{l}\text { Percent Solids } \\
\text { in Sludge }\end{array}$ & Characteristics \\
\hline Raw Primary & 900 to 1200 & 4 to 8 & $\begin{array}{l}\text { Gray-brown, slimy; } \\
\text { vile, bad odor; } \\
\text { putrifies; easilv } \\
\text { digested and } \\
\text { dewatered }\end{array}$ \\
\hline Waste Activated & 600 to 900 & 0.5 to 2 & $\begin{array}{l}\text { Yellow-brown floccu- } \\
\text { lent appearance; } \\
\text { unoffensive musty } \\
\text { odor; tends to become } \\
\text { septic rapidly; digests } \\
\text { readily; difficult to } \\
\text { dewater; very active } \\
\text { biologically }\end{array}$ \\
\hline Chemical Sludge & 3000 to 4500 & 7 to 10 & $\begin{array}{l}\text { Black, may be reddish; } \\
\text { objectionable odor; } \\
\text { slimy, but gelatinous; } \\
\text { decomposition is slower } \\
\text { than primary sludge; } \\
\text { difficult to dewater. }\end{array}$ \\
\hline Anaerobic Digested & 600 to 850 & 5 to 10 & $\begin{array}{l}\text { Black; musty odor; } \\
\text { dewaters well on } \\
\text { drying beds. }\end{array}$ \\
\hline $\begin{array}{l}\text { Ainaerobic Digested } \\
\text { Mixed Primary and } \\
\text { Waste Activated }\end{array}$ & 1000 to 1500 & 2 to 4 & $\begin{array}{l}\text { Black-brown; musty } \\
\text { odor; not as easy to } \\
\text { dewater as digested } \\
\text { primary. }\end{array}$ \\
\hline
\end{tabular}


Costs are presented in this report for various sludge treatment schemes. These treatment schemes are grouped into one of the following three categories according to the end products produced:

- Options A - Dry sludge products that finish the treatment process at 45 to $100 \%$ solids

- Options B - Moist or dewatered sludge products that finish the treatment process at 15 to $45 \%$ solids

- Options C - Wet sludge products that finish the treatment process at about $5 \%$ solids.

The sludge treatment and disposal schemes presented have been costed from a point of common sludge influent to final disposal. The entire treatment train was costed so as to create estimates that were as uniform as possible. However, inequities do exist. Many processes discussed in this report have been used for a number of years and their cost estimates are based on actual experience. Other processes are not in use and estimates for these are based on limited information relative to design and operation. Thus, a cost difference of less than $15 \%$ may be insignificant.

This report also contains an analysis comparing the reuse of wet and dry sludge in terms of the cost differential for transporting wet and dry sludge, differences in sludge handling characteristics, and pathogen growback in sludges of various moisture content. Other sections include a comparison of the processes producing a dry, disinfected product; an evaluation of the treated sludge product with respect to disinfection and odor; a summary of the effect of heavy metals on sludge reuse; and a cost/benefit analysis. 


\section{RECOMMENDATIONS}

This report serves as a preliminary analysis investigating the potential of the radiation treatment process conceptualized by Sandia Laboratories, located in Albuquerque, New Mexico. Additional work in the following areas would significantly improve the analysis.

1. The costs developed for all treatment schemes presented were based on single assumptions made with no real intent to optimize the process. Therefore, a sensitivity study should be conducted to better understand the relative economics of each treatment method. For example, the effects of heat recovery, which was not assumed for costs presented in this report, should be investigated. Likewise, the effects of recovering other beneficial products (methane), changing the amortization factors, and altering the unit price for power, fuel and materials should be studied.

2. The economic comparison presented is for new treatment plants. However, few new treatment plants will be built in comparison to those expanded. Thus, a cost comparison should be conducted to investigate the relative economics of adding disinfection to existing sludge treatment schemes. This analysis would allow the comparison of various sludge disinfection processes in a more realistic situation.

3. Pyrolysis is currently being marketed as a heat treatment alternative. Reliable pyrolysis cost data is becoming available. Therefore, the economics of radiation treatment and pyrolysis should be investigated.

In addition to the items above, it is recommended that a scenario be developed, based on sound engineering analysis, to predict how many treatment plants would implement radiation treatment if a highly disinfected sludge product was required. The scenario should consider the decision factors that municipalities use in determining their optimum sludge treatment alternatives, land-use parameters and regulatory restraints should be considered as part of the decision-making process. Such a scenario would identify municipal situations that are amenable to radiation treatment. 


\section{COSTS FOR SLUDGE TREATMENT AND DISPOSAL}

The following treatment schemes have been costed to determine their relative economic desirability. A technical description of the various processes used to makeup the treatment schemes is presented in Appendix A. The documentation for the costs developed in this report comprises Appendix $B$.

\section{OPTIONS A: DRY SLUDGE}

Figure 1 shows the various treatment schemes considered for producing a dry sludge product. Costs were calculated for each option for plants with a wastewater flow of 5 million gallons/day (mgd), $50 \mathrm{mgd}, 100 \mathrm{mgd}$, and $200 \mathrm{mgd}$. The relative costs are shown in Table 2 in terms of cents per 1000 gallons of wastewater flow. Figure 2 presents a graphical display of the costs for plants ranging from $50 \mathrm{mgd}$ to $200 \mathrm{mgd}$. The $5 \mathrm{mgd}$ plant costs were not plotted because their large value extended the plotted range of costs such that it was difficult to read the graph accurately. However, the 5 mgd costs are a valid component of this study.

Option $\mathrm{A}_{2}$ (vacuum filter-compost-irradiate) indicates that radiation treatment of dry sludge is less expensive than every alternative considered except Option $A_{7}$ (vacuum filter-compost). However, the radiation process produces a much higher level of disinfection. Options $A_{11}$ (thermal conditionvacuum filter-flash dry) and $A_{13}$ (vacuum filter-incinerator) are the most expensive. These are followed by a group of options $\left(A_{1}, A_{4}, A_{5}, A_{6}, A_{8}\right.$, and $A_{12}$ ) which are similar in cost. The high cost of these options is attributed to the flash drying process. The remaining options are ordered $A_{10}$ (1 ime stabilization-vacuum filter-flash dry), $A_{3}$ (digest-vacuum filtercompost-irradiate), and $A_{9}$ (digest-vacuum filter-compost) with $A_{9}$ being less expensive than $A_{3}$ or $A_{10}$.

\section{OPTIONS B: MOIST OR DEWATERED SLUDGE}

The various schemes that produce moist sludge residue are shown in Figure 3. Table 3 indicates the cost of each option for several plant sizes and Figure 4 compares these costs graphically for the larger plant sizes. 


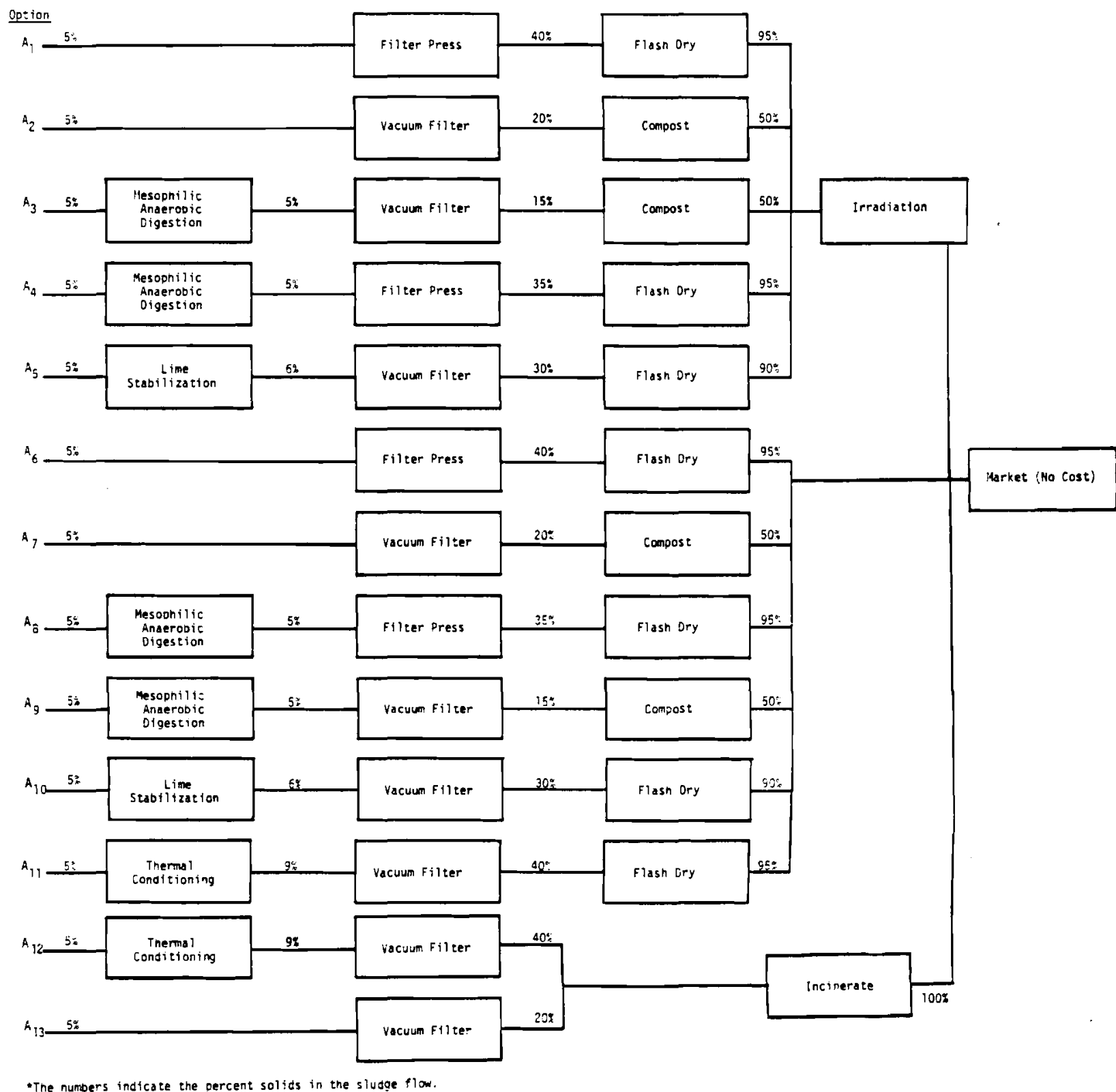

FIGURE 1. Options A: Dry Sludge Treatment Schemes 
TABLE 2. Dry Sludge Treatment Costs ( $\$ / 1000 \mathrm{gal}$ of wastewater)

\begin{tabular}{|c|c|c|c|c|c|c|c|c|c|c|c|c|c|c|c|c|c|c|c|c|}
\hline \multirow[b]{2}{*}{ option! } & \multirow{2}{*}{\multicolumn{3}{|c|}{ Capital 0\&y }} & \multirow[b]{2}{*}{ Dispos } & \multirow[b]{2}{*}{ Total } & & \multicolumn{5}{|c|}{100 wgd } & \multicolumn{5}{|c|}{$200 \mathrm{mgd}$} \\
\hline & & & & & & Capital & $08 \mathrm{~A}$ & Source & Disposal & Iotal & Capital & OBM & Source & Disposa & IotaI & Capital & Q61M & Source & Disposal & Total \\
\hline$A_{1}$ & 10.61 & 14.46 & 0.18 & 0 & 25.31 & 3.71 & 8.68 & 0.13 & 0 & 12.52 & 2.90 & 8.17 & 0.13 & 0 & 11.20 & 2.34 & 7.82 & 0.13 & 0 & 10.29 \\
\hline$A_{2}$ & 5.73 & 11.38 & 0.31 & 0 & 17.43 & 2.30 & 5.97 & 0.24 & 0 & 8.51 & 1.62 & 5.37 & 0.24 & 0 & 7.23 & 1.34 & 4.82 & 0.24 & 0 & 6.40 \\
\hline$A_{3}$ & 7.11 & 11.16 & 0.21 & 0 & 19.07 & 4.10 & 5.61 & 0.16 & 0 & 9.87 & 3.68 & 5.04 & 0.16 & 0 & 8.88 & 3.45 & 4.38 & 0.16 & $\mathbf{0}$ & 7.99 \\
\hline$n_{4}$ & 11.61 & 12.84 & 0.12 & o & 24.57 & 4.96 & 0.15 & 0.08 & o & 11.79 & 4.47 & 6.19 & 0.08 & 0 & 10.74 & 4.02 & 5.70 & 0.08 & 0 & 9.80 \\
\hline$A_{5}$ & 9.80 & 11.07 & 0.22 & 0 & 21.09 & 3.66 & 8.38 & 0.16 & 0 & 12.20 & 2.74 & 7.61 & 0.16 & 0 & 10.51 & 2.07 & 6.98 & 0.16 & 0 & 9.21 \\
\hline$n_{6}$ & 0.61 & 13.99 & & 0 & 22.60 & 3.11 & 8.51 & & $\mathbf{0}$ & 11.62 & 2.49 & 8.02 & & 0 & 10.51 & 2.07 & 1.69 & & 0 & 9.76 \\
\hline$n$, & 2.92 & 10.31 & & 0 & 16.91 & 1.56 & 5.64 & & $\mathbf{0}$ & 7.24 & 1.12 & 5.11 & & 0 & 6.23 & 1.01 & 4.56 & & 0 & 5.57 \\
\hline$A_{B}$ & 9.98 & 12.42 & & 0 & 22.40 & 4.41 & 6.63 & & 0 & 11.10 & 4.13 & 6.09 & & 0 & 10.22 & 3.79 & 5.60 & & 0 & 9. 39 \\
\hline$A_{9}$ & 5.31 & 10.63 & & 0 & 16.94 & 3.45 & 5.41 & & 0 & 8.86 & 3.24 & 4.86 & & 0 & 8.10 & 3.15 & 9.21 & & 0 & 7.36 \\
\hline$n_{11}$ & 7.40 & 12.52 & & 0 & 19.92 & 3.00 & 8.10 & & 0 & 11.18 & 2.29 & 7.43 & & 0 & 9.72 & 1.76 & 6.81 & & 0 & 8.57 \\
\hline$A_{11}$ & 10.43 & 16.47 & & 0 & 26.90 & 4.46 & 9.11 & & 0 & 14.23 & 3.47 & 8.77 & & 0 & 12.24 & 2.70 & 7.90 & & & 10.60 \\
\hline$A_{12}$ & 15.06 & 16.65 & & 0 & 31.11 & 4. 52 & 8. 26 & & 0 & 12.78 & 3.58 & 7.24 & & 0 & 10.82 & 2.96 & 6.44 & & 0 & 9.40 \\
\hline$n_{13}$ & 11.21 & 14.57 & & 0 & 29.78 & 2.70 & 10.40 & & 0 & 13.10 & 2.13 & 9.80 & & 0 & 11.93 & 1.80 & 9.72 & & 0 & 11.52 \\
\hline
\end{tabular}




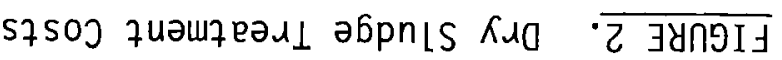

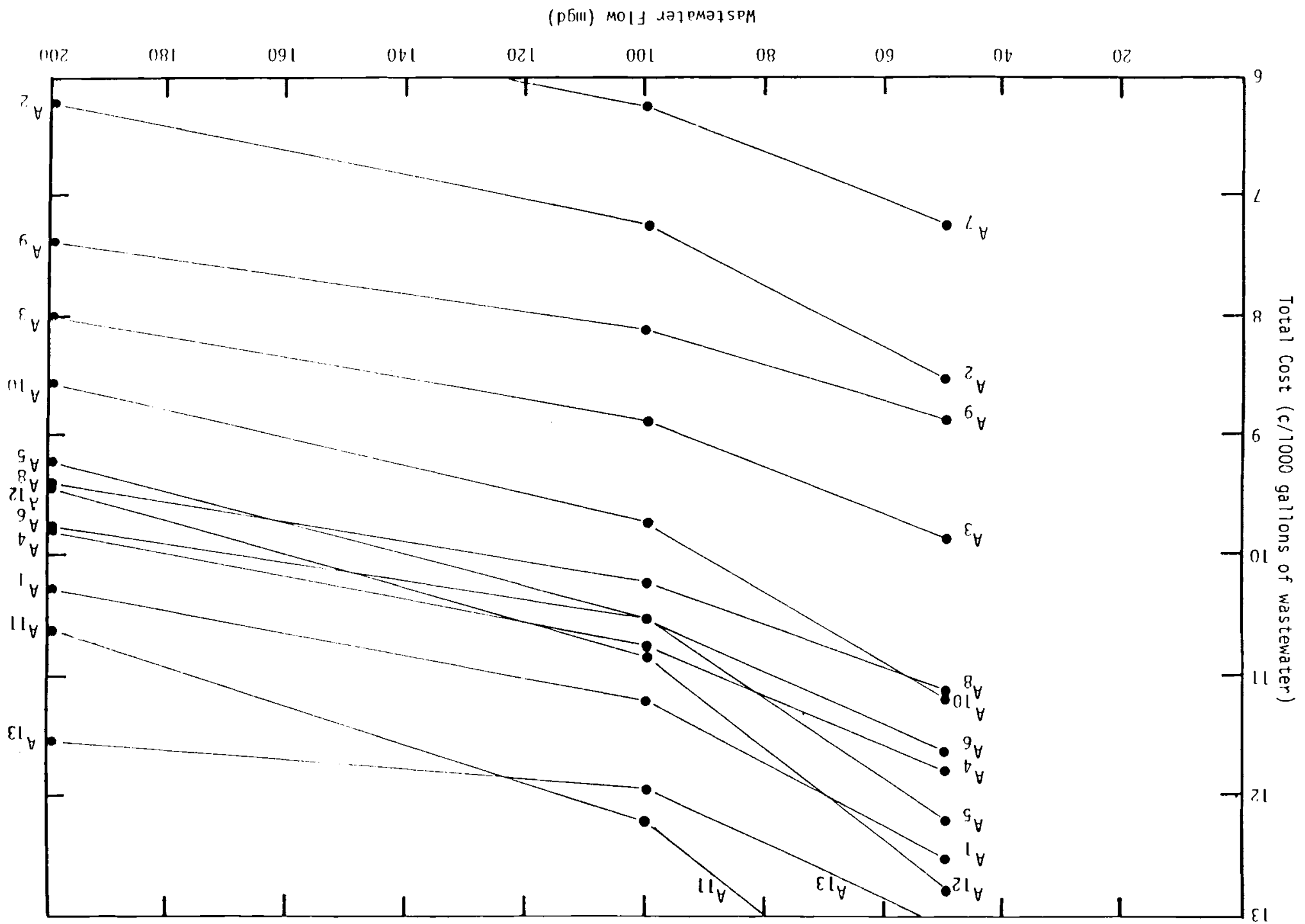




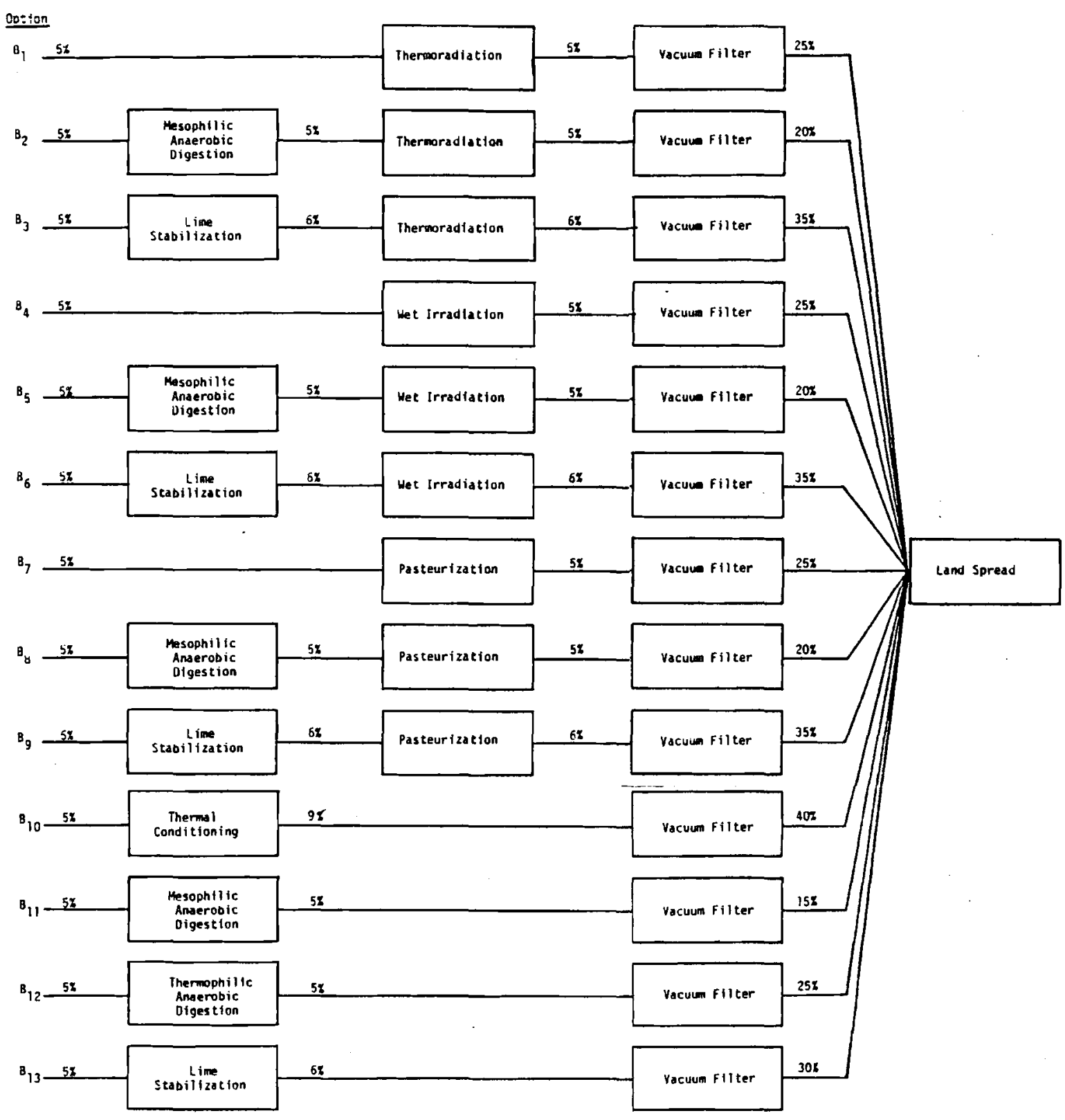

*The numbers indicate the percent sollds in the sludge flow.

FIGURE 3. Options B: Moist Sludge Treatment Schemes 
TABLE 3. Moist Sludge Treatment Costs ( $\$ / 1000$ gal of wastewater)

\begin{tabular}{|c|c|c|c|c|c|c|c|c|c|c|c|c|c|c|c|c|c|c|c|c|}
\hline & & & 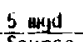 & & & & & $50 \mathrm{mgd}$ & & & & & 100 angd & & & & & $200 \mathrm{gggd}$ & & \\
\hline Oplion & Copl(a) & OAM & irce & Disposal & Total & Capital & $08 \mathrm{~A}$ & Source & Disposal & Totar & squtal & $08 \mathrm{~B}$ & Source & oisposd & TotdT & Capital & 0\&M & Source & Disposal & Total \\
\hline$B_{1}$ & 3.85 & 1.91 & 0.38 & 3.18 & 15.32 & 1.32 & 3.52 & 0.29 & 1.38 & $6: 11$ & 1.08 & 2.97 & 0.29 & 1.39 & 5.73 & 0.90 & 2.56 & 0.29 & 1.31 & 5.06 \\
\hline $\mathrm{B}_{2}$ & 6.25 & 1.82 & 0.38 & 2.83 & 17.28 & 3.15 & 3.38 & 0.29 & 1.28 & 8.10 & 3.11 & 2.82 & 0.29 & 1.14 & 7.36 & 2.97 & 2.29 & 0.29 & 1.06 & 6.61 \\
\hline$B_{3}$ & 4.68 & 10.01 & 0.38 & 3.00 & 18.07 & 1.68 & 4.06 & 0.29 & 1.41 & 7.46 & 1.36 & 3.40 & 0.29 & 1.29 & 6.34 & 1.12 & 2.90 & 0.29 & 1.17 & 5.48 \\
\hline $\mathbf{B}_{4}$ & 4.14 & 6.22 & 1.01 & 3.18 & 14.35 & 1.81 & 2.74 & 0.96 & 1.58 & 7.15 & 1.62 & 2.25 & 0.96 & 1.39 & 6.22 & 1.41 & 1.57 & 0.96 & I. 31 & 5.55 \\
\hline$B_{5}$ & 0.33 & 6. & 1.01 & 2.83 & 16.55 & 3.50 & 2.83 & 0.96 & 1.28 & 8.5) & 3.47 & 2.33 & 0.96 & 1.14 & 7.90 & 3.31 & 1.83 & 0.96 & 1.06 & 7.16 \\
\hline $\mathrm{B}_{6}$ & 4.97 & ४. 32 & 1.01 & 3.00 & 17.30 & 2.21 & 3.30 & 0.96 & 1.41 & 7.40 & 1.90 & 2.68 & 0.96 & 1.29 & 6.83 & 1.64 & 2.21 & D. 96 & 1.17 & 5.98 \\
\hline Bs & 2.54 & 6.97 & & 3.18 & 12.69 & 1.01 & 4.04 & & 1.58 & 6.63 & 0.82 & 3.46 & & 1.39 & 3.67 & 0.69 & 2.96 & & 1.31 & 4. 96 \\
\hline by & 5.12 & 6.63 & & 2.83 & 14.58 & 2.91 & 3.65 & & 1.28 & 7.84 & 2.91 & 3.07 & & 1.14 & 7.12 & 2.78 & 2.45 & & 1.06 & 6.29 \\
\hline$B_{9}$ & 3.64 & 9.01 & & 3.00 & 15.71 & 1.37 & 4.59 & & 1.41 & 7.37 & 1.10 & 3.89 & & 1.29 & 6.28 & 0.90 & 3.30 & & 1.17 & 5.37 \\
\hline$B_{10}$ & 3.33 & 10.53 & & 2.63 & 18.49 & 2.56 & 4.61 & & 1.15 & 8. 32 & 2.06 & 3.81 & & 0.98 & 6.85 & 1.66 & 3.14 & & 0.91 & 5.71 \\
\hline$B_{11}$ & 4.01 & 4.69 & & 3.18 & 11.88 & 2.11 & 2.59 & & 1.60 & 6.90 & 2.69 & 2.17 & & 1.45 & 6.31 & 2.68 & 1.11 & & 1.34 & 5.73 \\
\hline$B_{12}$ & 3. 26 & 4.69 & & 2.63 & 10.60 & 2.07 & 2.95 & & 1.12 & 6.14 & 2.06 & 2.47 & & 0.96 & 5.49 & 1.97 & 1.94 & & 0.04 & 4.19 \\
\hline 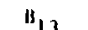 & .30 & .38 & & .23 & 2.11 & .10 & 3.01 & & .61 & .72 & .89 & 2.47 & & .4 & 1.78 &.$\pi$ & .05 & & 35 & 1.09 \\
\hline
\end{tabular}




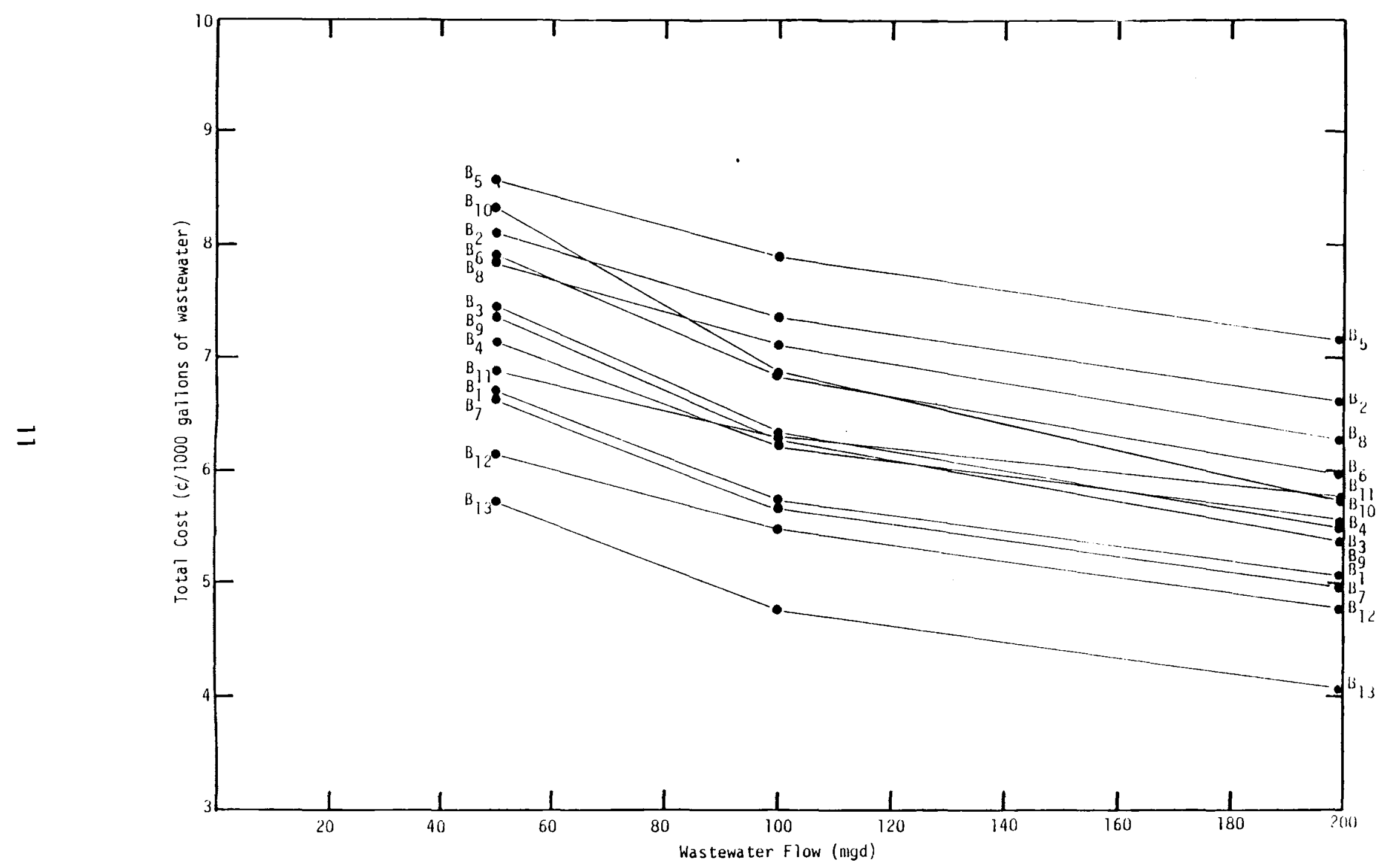

FIGURE 4. Moist Sludge Treatment Costs 
The costs for Options B indicate that the treatment schemes may be grouped into five economic levels. Listed from the least expensive scheme to the most expensive these levels include the following options:

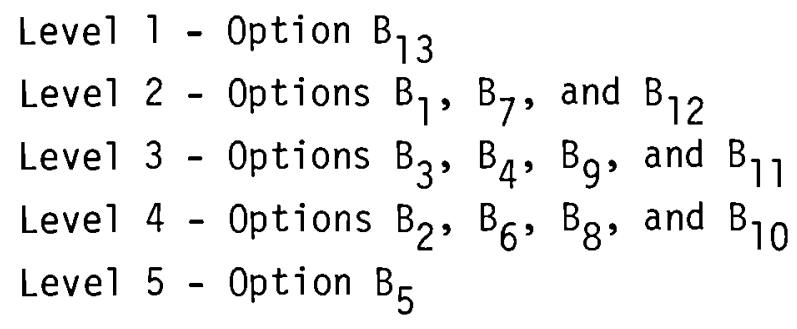

The least expensive radiation treatment option is $B_{1}$ (thermoradiation-vacuum filter). This option falls into the second most desirable economic level. However, no stabilization process is incorporated in this option and the degree to which the sludge could be reused is very limited. The third level of economic desirability includes treatment option $B_{3}$. This option is the same as $B_{1}$ but incorporates liming to stabilize the sludge. Therefore, radiation treatment does not produce a usable sludge product until the third level of economic desirability is reached.

\section{OPTIONS C. WET SLUDGE}

Options $C$ consist of the wet sludge treatment schemes shown in Figure 5 . The cost for each scheme is compiled in Table 4 and Figure 6.

Sludge lagooning preceded by mesophilic anaerobic digestion (option $\mathrm{C}_{4}$ ) is the least expensive method of treatment provided sufficient land is available. Anaerobic digestion (options $C_{5}$ and $C_{6}$ ) and lime stabilization (option $C_{7}$ ) constitute the next expensive treatment schemes. The options that utilize radiation treatment or thermal pastuerization for disinfection (options $C_{1}, C_{2}, C_{3}, C_{8}, C_{9}, C_{10}$ ) are the most expensive. By comparing option $C_{10}$ with options $C_{8}$ and $C_{9}$ or options $C_{3}$ with options $C_{1}$ and $C_{2}$ it can be concluded that thermal pasteurization is less expensive than radiation treatment. 


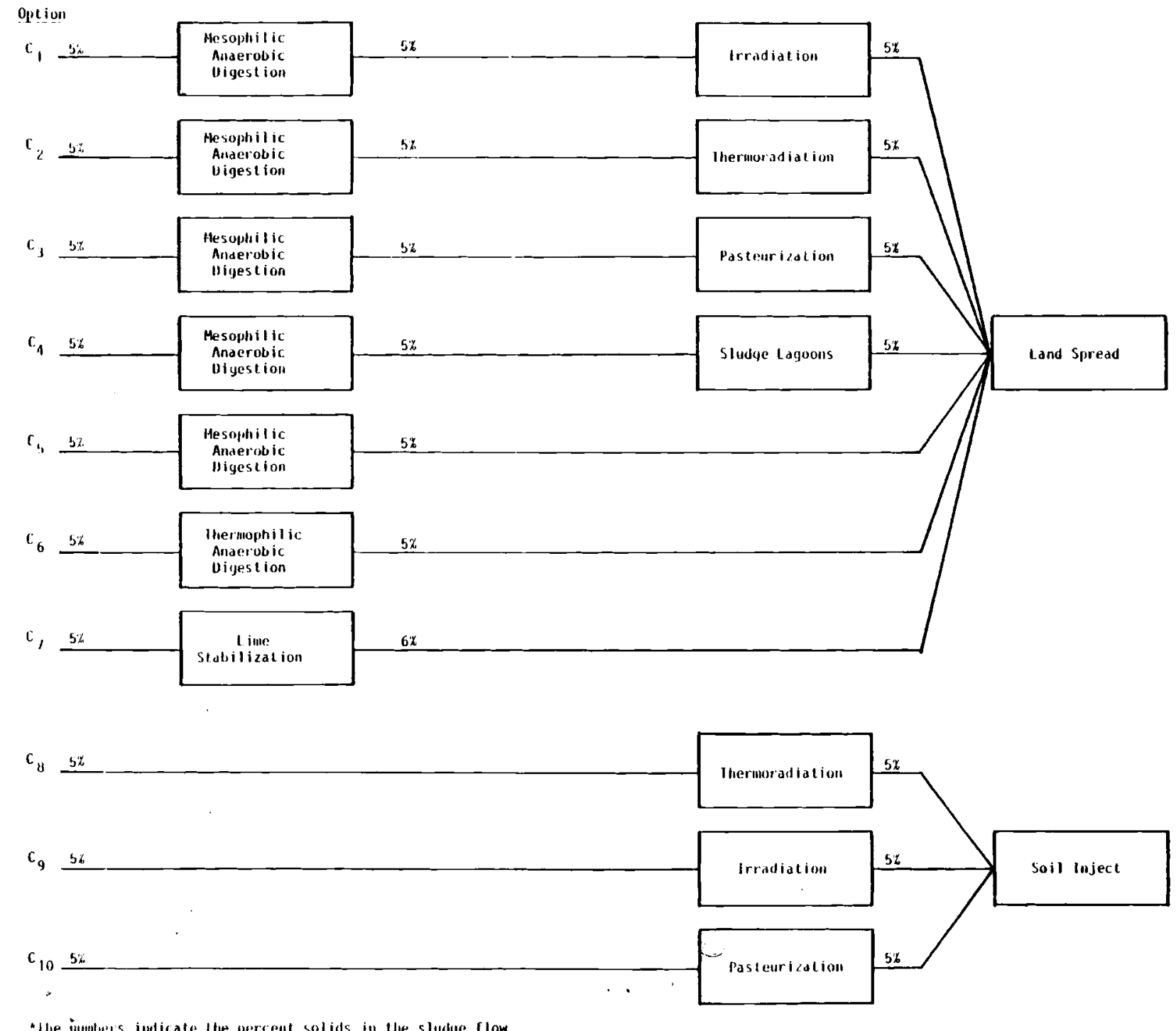

FIGURE 5. Options C: Wet Sludge Treatment Schemes 
TABLE 4. Wet Sludge Treatment Costs (\%/1000 gal of wastewater)

\begin{tabular}{|c|c|c|c|c|c|c|c|c|c|c|c|c|c|c|c|c|c|c|c|c|}
\hline & & & 5 & & & & & 50 mydu & & & & & & & & & & & & \\
\hline (0)! & Copital & $O 8 \mathrm{M}$ & Source & Díposal & Total & Couitol & OQM & Source & Disposal & Total & capital & $\underline{O A M}$ & Source & Disposal & Total & Capital & $\underline{O B M}$ & Source & DIsposal & Total \\
\hline 1 & 5.15 & 3.12 & 1.01 & 6.32 & 15.60 & 2.99 & 1.05 & 0.96 & 4.47 & 9.51 & 2.98 & 0.84 & 0.96 & 4.28 & 9.06 & 2.92 & 0.69 & 0.96 & 4.19 & 8.76 \\
\hline 2 & 5.116 & 4.56 & 0. 38 & 6. 32 & 16.32 & 2.65 & 1.59 & 0.29 & 4.47 & 9.00 & 2.63 & 1.33 & 0.29 & 4.28 & 8.53 & 2.57 & 1.15 & 0.29 & 4.19 & 8.20 \\
\hline 3 & 3.44 & 3.36 & & 6.32 & 13.62 & 2.45 & 1.87 & & 4.47 & 8.79 & 2.43 & 1.58 & & 4.28 & 8.29 & 2.39 & 1.31 & & 4.19 & 7.89 \\
\hline & 3.52 & 2,40 & & $\begin{array}{l}\text { lncl ouded } \\
\text { in } 08 M M\end{array}$ & 5.92 & 2.69 & 1.38 & & $\begin{array}{l}\text { Inc luded } \\
\text { in } 0 \& M\end{array}$ & 4.07 & 2.68 & 1.17 & & $\begin{array}{l}\text { Included } \\
\text { in } 08 \mathrm{~A}\end{array}$ & 3.85 & 2.65 & 1.00 & & $\begin{array}{l}\text { Included } \\
\text { in } 0 B M\end{array}$ & 3.65 \\
\hline & 2.82 & 1.43 & & 6.32 & 10.57 & 2.29 & 0.41 & & 4.47 & 7.57 & 2.28 & 0.68 & & 4.28 & 7.24 & 2.28 & 0.57 & & 4.19 & 7.04 \\
\hline & 2.19 & 1.43 & & 6.32 & 9.94 & 1.62 & 1.16 & & 4.47 & 1.25 & 1.61 & 0.98 & & 4.28 & 6.87 & 1.61 & 0.69 & & 4.19 & 6.49 \\
\hline & 0.42 & 1.45 & & 8.63 & 10.70 & 0.25 & 0.20 & & 6.74 & 7.19 & 0.20 & 0.13 & & 6.56 & 6.89 & 0.15 & 0.09 & & 6.47 & 6.11 \\
\hline & 2.38 & 3.43 & & 8.84 & 15.08 & $0.58 \mathrm{~d}$ & 1.06 & 0.29 & 7.11 & 9.04 & 0.47 & 0.92 & 0.29 & 6.89 & 8.57 & 0.40 & 0.84 & 0.29 & 6.81 & 8.34 \\
\hline & 2.67 & 1.73 & & B.89 & 14.30 & 1.12 & 0.28 & 0.96 & 7.11 & 9.47 & 1.01 & 0.20 & 0.96 & 6.89 & 9.06 & 0.92 & 0.16 & 0.96 & 6.81 & 8.85 \\
\hline & 1.35 & 2.49 & & 8.89 & 12.13 & 0.27 & 1.58 & & 7.11 & 8.96 & 0.21 & 1.41 & & 6.89 & 8.51 & 0.19 & 1.24 & & 6.81 & 0.24 \\
\hline
\end{tabular}




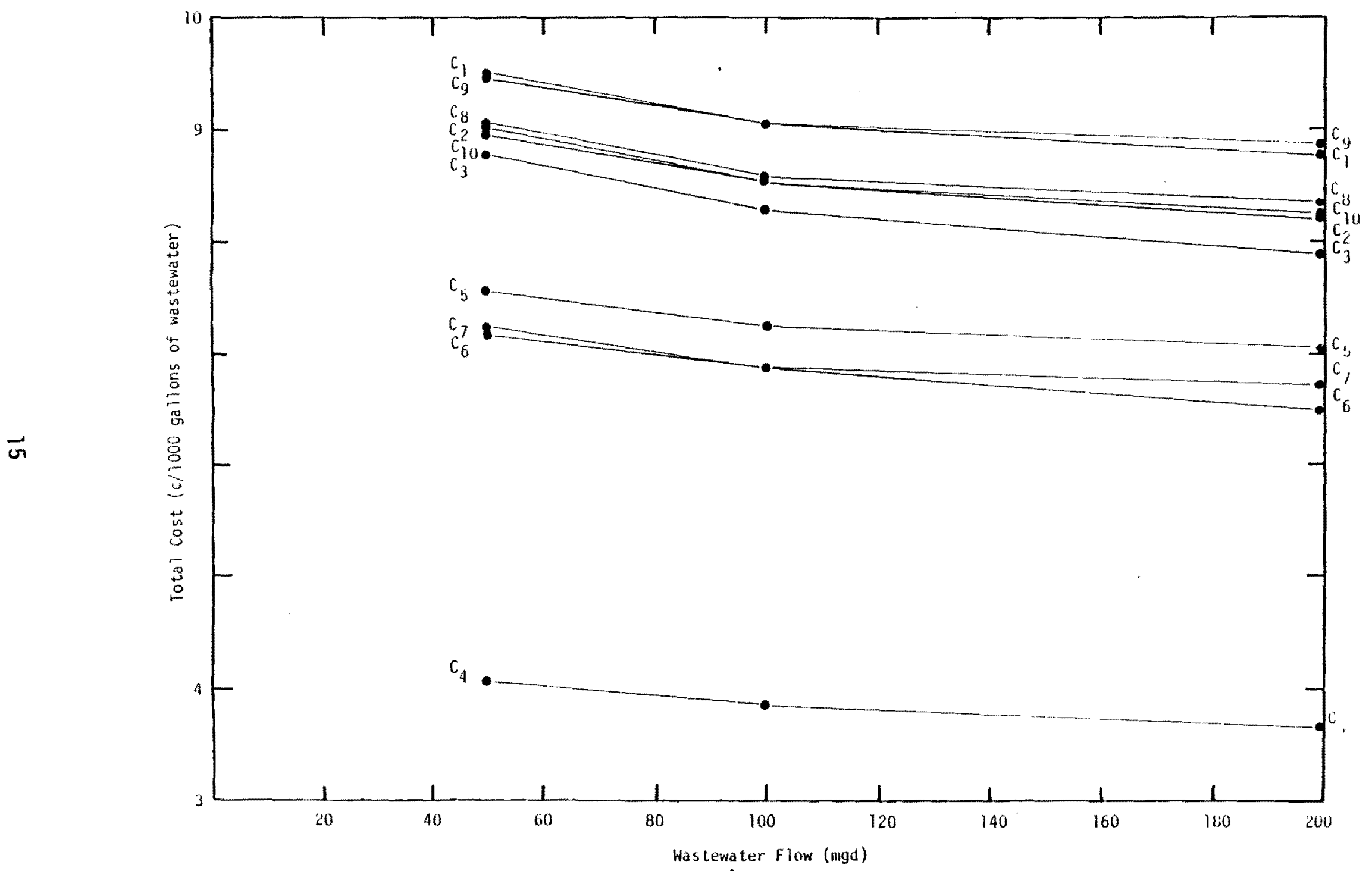

FIGURE 6. Wet Sludge Treatment costs 
SUMMARY

Radiation is an attractive alternative for producing a dry, disinfected sludge-product but becomes less viable as the water content of the sludge increases. 


\section{COMPARISON OF WET AND DRY SLUDGE REUSE}

Significant characteristic differences exist between wet and dry sludge. It is important to outline these differences when considering sludge for beneficial reuse. Thus, the following discussion considers differences in transport costs, handling characteristics, and pathogen growback resulting from different degrees of moisture content in sludge.

\section{TRANSPORT COSTS}

The beneficial reuse of municipal sewage sludge usually requires the product be transported. Figure 7 compares the costs of hauling sludges with a different solids content from a 100 mgd plant by truck. The economic basis for this figure is explained in Appendix B.

The cost of transporting dewatered sludge by truck is much lower than that of liquid sludge. For distances over 10 miles the cost for the dewatering process is easily covered by the savings in transport cost. Therefore, it is not economical to transport liquid sludge by truck over 10 miles because of the large volume of water that must be hauled. Liquid sludge can be transported economically over long distances by pipeline if the pipeline remains useful for 20 years or more. (1)

The difference in transporting dewatered and dried sludge is not sufficient to cover the increased cost for sludge drying. Thus, from a pure economic standpoint, dewatered sludge is the best to transport. However, the method of sludge reuse sometimes makes dried sludge more desirable.

\section{HANDL ING CHARACTERIST ICS}

Transporting dried sludge by truck is much easier than transporting wet sludge. A hopper or dozer can be used to load the material into open or closed trucks. Dry sludge is also easier to store requiring no specialized facilities. Additionally, dried, disinfected sludge can be bagged for distribution as soil amender or animal feed, whereas wet sludge must be stored in tanks and then piped to tank trucks for transportation to a reuse or disposal site. 


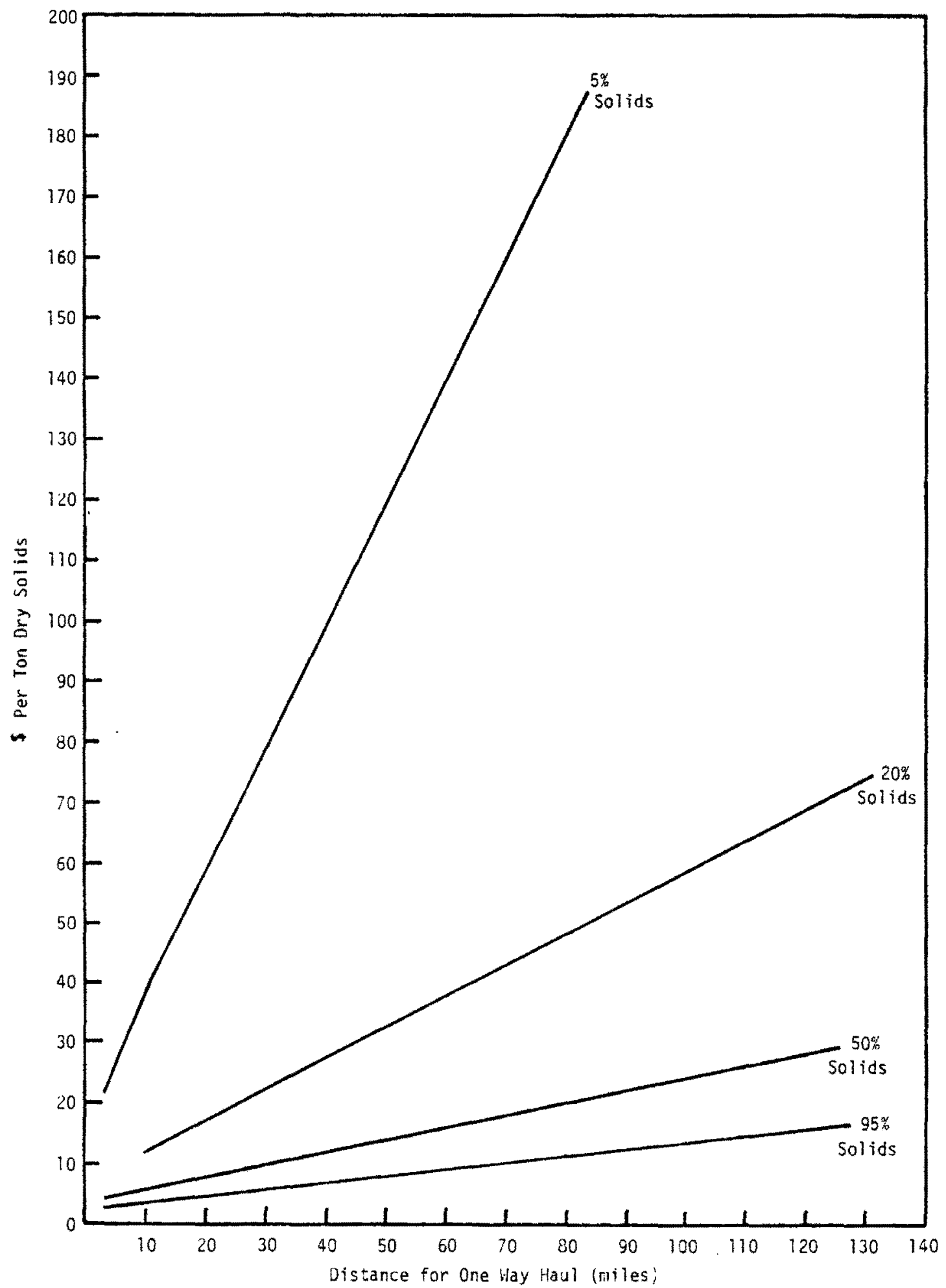

FIGURE 7. Cost of Transporting Sludge by Truck from a 100 mgd Plant 


\section{PATHOGEN GROWBACK}

Disinfected sewage sludge, with its high organic content, is frequently subject to reintroduction of pathogenic bacteria. Water is essential to the transmission of active forms of pathogens. When water is not present, the spread of pathogens is limited to short range transmission through air. Therefore, dried sludge provides a comparatively unfavorable environment for pathogen growback. Dry disinfected sludge is more resistant to pathogen growback than wet sludge.

\section{SUMMARY}

Treatment schemes to produce wet sludge are simpler and cheaper than those to produce dewatered or dried sludge. However, because of the problems associated with handling and transporting wet sludge, a dry sludge product is usually more desirable for reuse. 


\section{COMPARISON OF PROCESSES PRODUCING A DRY, DISINFECTED PRODUCT}

The previous section outlined reasons why a dry sludge product is preferable for marketing or beneficial reuse. In agreement with this, several composting research operations are currently underway in the United States with hopes of producing a safe, reusable, dry sludge. However, questions have arisen concerning the pathogen level in the composted sludge.

In this section three options will be compared to determine the relative costs of producing a disinfected, dry sludge which could have almost unlimited reuse. These options are:

- Vacuum filter $\rightarrow$ compost $\rightarrow$ radiation $\left(A_{2}\right)$

- Filter press $\rightarrow$ flash dry $\left(A_{6}\right)$

- Thermal condition $\rightarrow$ vacuum filter $\rightarrow$ flash dry $\left(A_{11}\right)$

Figure 8 presents the cost comparision for these three alternatives. The data shows that composting followed by radiation is the least expensive form of producing a dry, pathogen free product. 


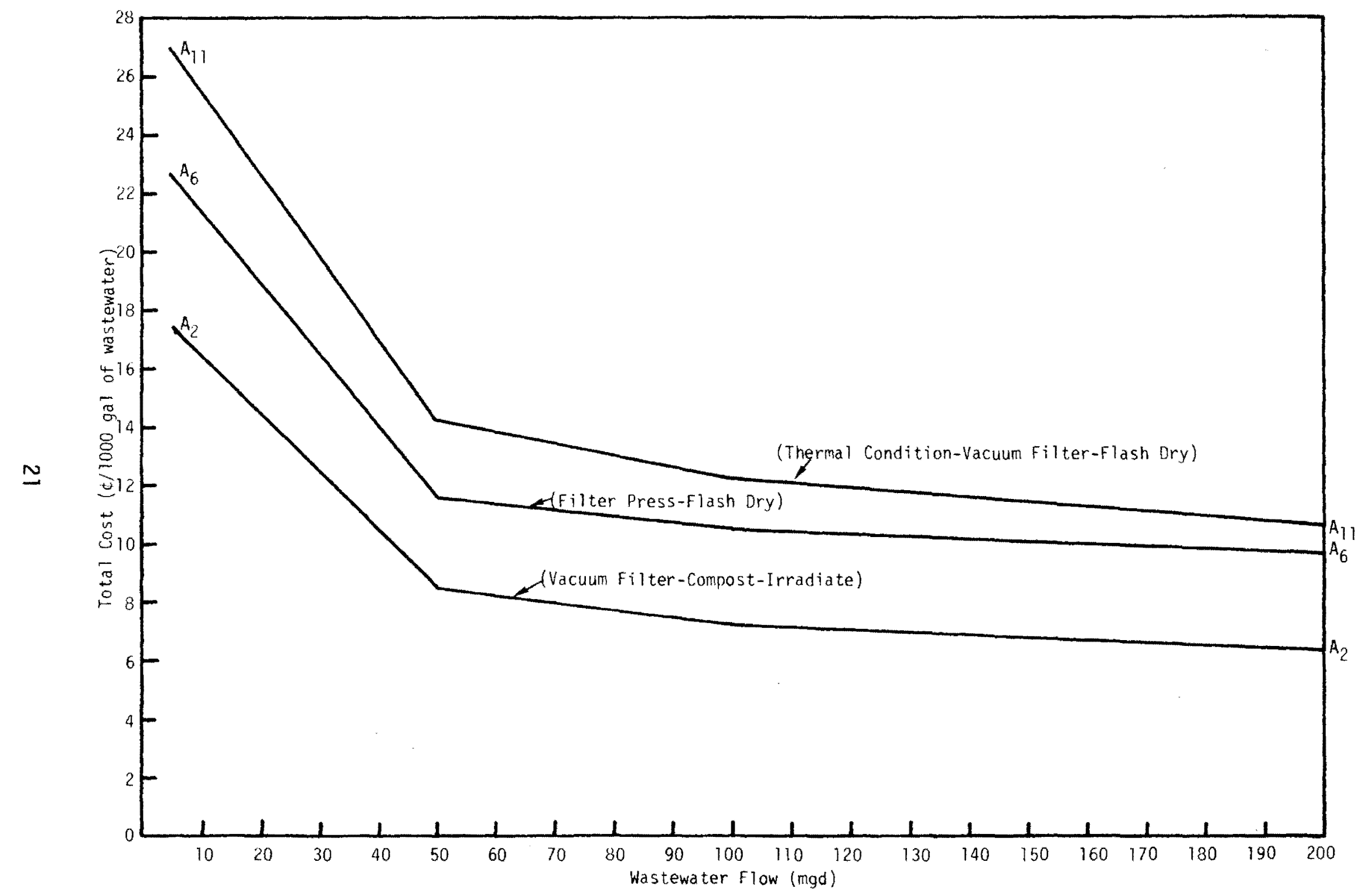

FIGURE 8. Costs of Heat Treatment and Irradiation Processes 


\section{EVALUATION OF THE TREATED SLUDGE PRODUCT}

The cost of a treatment scheme is an important consideration in choosing the most desirable method of sludge treatment. However, it does not constitute the sole decision criteria. The degree of treatment received is also a major factor. This section will evaluate the effect a treatment process has on two important parameters--disinfection and odor.

\section{DISINFECTION}

A wide variety of pathogenic bacteria, virus and parasites occurs in municipal sludge. A partial list of human enteric pathogens occurring in sludge and the diseases associated with the pathogen is given in Table 5 . This section outlines the major sludge treatment process. Table 6 indicates the disinfection achieved by these processes.

- Mesophilic anaerobic digestion is the most popular method of biologically stabilizing municipal sludges. Studies ${ }^{(2)}$ have indicated that mesophilic digestion can effectively reduce the concentrations of such bacteria as Endamoeba hystoloytica $(<100 \%)$, Salmonella thyphosa $(92 \%)$, Tuberculibacilli $(95 \%)$, and Escherichia coli $(<100 \%)$. Additional work ${ }^{(3)}$ shows that an anaerobically digested sludge contains an agent with virucidal activity against polio virus. Although digestion reduces bacteria and virus populations, it does not disinfect sludge. Therefore, mesophilic anaerobic digestion cannot be relied upon to lower levels sufficiently for safe land use or to retard growback of pathogens. Recent studies at the Hyperion Treatment Plant in Los Angeles, California, indicate the degree of pathogen destruction achievable through thermophilic anaerobic digestion is significantly higher. Pathogenic bacteria and indicator organisms present in the raw sludge are essentially destroyed. Further studies are needed to determine the effect and extent of biological growback of the pathogenic bacteria. 
TABLE 5. Pathogenic Organisms Which can Potentially be Transmitted by Water, Sewage, and Sludge (Source: Reference 5)

Causative Agent

Poliovirus

Virus

Coxsackievirus

Echovirus

Mild Infections

Disease

Poliomyelitis

Infectious Hepatitis

Mild Infections

Revirus

\section{Remarks}

Exact mode of transmission not yet known. Found in effluents from biological sewage treatment plants.

"Viral hepatitis" is a generic term that covers at least two distinct forms of hepatitis. Hepatitis type $A$, known as "infectious hepatitis", is. the generally accepted term for epidemic, communityacquired disease. Type $A$ virus is present in the feces and blood of infected persons who can contaminate milk, food, and water. Hepatitis type B, also known as "serum hepatitis", is ordinarily transmitted by the parenteral route and is commonly associated with drug abuse and transfusion of blood and blood products.

Responsible for asceptic meningitis pleurodynia, and infantile myocarditis. They commonly cause diarrhea in infants and young children.

These viruses (enteric cytopathogenic human orphon viruses) have been associated with $i 1$ nesses of asceptic meningitis, rash, and respiratory diseases.

Diarrhea and respiratory diseases similar to those noted for adeno-virus. 


\section{TABLE 5. (Cont'd)}

\section{Causative Agent}

Adenovirus

Gastroenteritis and diarrhea virus

Coliform Species

Pseudomonas Species

Proteus Species

Vibrio Comma

Salmonella (many species)
Disease

Respiratory Infections

Diarrhea and Interna 1 Infections

Diarrhea

Diarrhea

Cholera

Salmonel los is
Remarks

Many of the adenoviruses have been associated with a variety of respiratory diseases (i.e, colds, influenza-1ike illnes: ses, bronchitis, croup, a typical pneumonia).

Causative agents not known but thought to be viral in some instances. In terms of magnitude, gastroenteritis and diarrheal disease are probably most important diseases transmitted by water.

Implicated in several cases of infant diarrhea in hospitals. In rare cases known to cause cardiovascular infections.

Transmitted by sewage and polluted waters. Disease often terminates in death. Endemic in India and S.E. Asia. Has occurred in Europe and $N$ \& $S$ America. No reported cases in U.S. since 1913. During an epidemic in London in 1854, the causative organism was shown to be transmitted in water, making cholera the first disease for which this important fact was known.

Salmonellosis may range in severity from intestinal discomfort to fatal disease such as typhoid fever (see below). Food infections from salmonella are quite common. 
TABLE 5. (Cont'd)

Causative Agent

Salmonella Typhosa

Salmonella

Paratyphosa

Shigella Dysenteriae and Others

Bacillus Anthracis

Brucella

Mycobacterium

Tuberculosis
Disease

Typhoid Fever

Paratyphoid Fever

Shigellosis, Bacillary Dysentary

Anthrax

Brucellosis - Malta

or undulant fever

in man. Contagious abortion-Bang's

disease in sheep, goats, cattle.

Tuberculosis
Remarks

Occurs in all parts of the world but infrequently where good sanitation and purification of water is practiced. Can survive in water for a week or more, also transmitted by milk, common in sewage and effluents in times of epidemics.

Resembles typhoid fever but is usually less severe. Common in sewage and effluents in times of epidemics.

Dysentery is a clinical condition with intestinal inflamation, diarrhea, and water stools containing blood, mucus, and pus. Polluted water main source of infection.

Found in sewage. Spores resistant to treatment. In man generally appears as a disease of the skin. Can be fatal if left untreated.

Norma $11 y$ transmitted by infected milk or by contact. Sewage also suspect.

Isolated from sewage and polluted streams. Water is a possible mode of transmission. Care with sewage and sludge from sanatoria. Deaths have been sharply reduced by early detection and treatment. Est. 80,000 new cases per year in U.S. WHO reports death rate in Central and S. America three times greater than in $\mathrm{N}$. America. 
TABLE 5. (Cont'd)

Causative Agent

Leptospira Icterohaemorrhagia

Entamoeba Histolytica

Giardia-Lamblia (Flagellated Protozoan)

Schis tosoma
Disease

Leptospirosis (Weil's Disease)

Amoebic Disentery

Giardiasis Giardia Infection

Schistosomiasis Bilharzia (Blood Flukes) In $N$. America a mild disease called

"swimmer's itch". Liver and Intestinal Flukes
Remarks

Jaundice-like disease in man. Carried by sewer rats or contaminated water. Documented as occurring in sewer workers in England.

Spread by contaminated waters and sludge used as fertilizer. Also transmitted by uncooked vegetables fertilized by sewage or sludge. Common warmer countries. Organism can form a cyst which is resistant to disinfection.

Clinical manifistations range from asymptomatic cyst passage to severe malabsorption. Mean duration of the illness is often 2 to 3 months. In 1974 an outbreak of Giardiasis occurred in Rome, NY, where 4800 persons were affected. Giardia cysts are not destroyed by chlorination at dosages and contact times normally employed in water treatment, but it is felt that they can be removed by coagulation.

Eggs excreted in urine or feces of infected person. Hatch on contact with water and enter snail host. Emerging cercariae penetrate directly into human skin. Infection may continue for years as an insidious drain on body vigor. Widespread in Africa, Near East and Orient where more than $90 \%$ of population may carry the worms. Egyptian government considers disease to be major obstacle to country's economic progress. Probably killed by efficient sewage treatment. 
TABLE 5. (Cont'd)

Causative Agent

Taenia

Ascaris Lumbricoides

Ancylostoma

Duoderale

Necator Americanus
Disease

Tape Worms

Round Worms Nematode Worms

Hookworm
Remarks

Eggs very resistant, present in sewage sludge and sewage effluents. Danger to cattle on sewage-irrigated land or land manured with sludge. Cattle in Southwest grazing on pastures treated with sludge tainted with eggs of Taenia saginata have contracted "beef measles."

Prevalent throughout the world. Described as "one of man's most faithful and constant companions from time immemorial." Danger to man from sewage effluents and dried sludge used as fertilizer.

Formerly very prevalent in the Southeastern United States. Infections developed in sewage farm workers in England. Adult worms live in intestines, fastening themselves to walls by means of their strong mouth parts. Eggs excreted in feces. Subsequent larval stage may enter host through skin. 
TABLE 6. Disinfection Ability of Some Sludge Treatment Processes

\begin{tabular}{|c|c|c|}
\hline Process & $\begin{array}{l}\text { Treatment } \\
\text { Specification }\end{array}$ & Disinfection \\
\hline $\begin{array}{l}\text { Mesophilic Anaerobic } \\
\text { Digestion }\end{array}$ & 25 days at $35^{\circ} \mathrm{C}$ & $\begin{array}{l}\text { Pathogen reduction with some virus } \\
\text { inactivation }\end{array}$ \\
\hline $\begin{array}{l}\text { Thermophilic Anaero- } \\
\text { bic Digestion }\end{array}$ & 16 days at $47.8^{\circ} \mathrm{C}$ & $\begin{array}{l}\text { Pathogen reduction improved over } \\
\text { mesophillic anaeorbic digestion }\end{array}$ \\
\hline Lime Stabilization & $\begin{array}{l}600 \text { lb lime per } \\
\text { ton dry sludge } \\
\text { solids }\end{array}$ & Pathogen reduction \\
\hline Thermal Conditioning & $\begin{array}{l}204^{\circ} \mathrm{C} \text { at } 150 \text { to } \\
400 \text { psig for } 20 \\
\text { to } 40 \text { minutes }\end{array}$ & $\begin{array}{l}\text { Pathogen inactivation (including } \\
\text { viruses) }\end{array}$ \\
\hline Flash Drying & $\begin{array}{l}\text { Gas Temperature of } \\
649^{\circ} \mathrm{C} \text { to } 760^{\circ} \mathrm{C}\end{array}$ & $\begin{array}{l}\text { Pathogen inactivation (including } \\
\text { viruses) }\end{array}$ \\
\hline Incineration & $\begin{array}{l}\text { Multiple Hearth } \\
\text { Furnance }\end{array}$ & $\begin{array}{l}\text { Pathogen inactivation (including } \\
\text { viruses) }\end{array}$ \\
\hline Composting & $\begin{array}{l}\text { Static Pile } \\
\text { Method - } 7 \text { weeks } \\
\text { with Temperatures } \\
\text { above } 66^{\circ} \mathrm{C}\end{array}$ & $\begin{array}{l}\text { General pathogen and virus inactiva- } \\
\text { tion }\end{array}$ \\
\hline Sludge Lagoons & $20^{\circ} \mathrm{C}$ & Pathogen reduction \\
\hline Irradiation & $\begin{array}{l}10^{6} \text { rads for } \\
3 \text { minutes }\end{array}$ & $\begin{array}{l}\text { Pathogen inactivation - Little virus } \\
\text { destruction }\end{array}$ \\
\hline Thermoradiation & $\begin{array}{l}55^{\circ} \mathrm{C} \text { and } 300,000 \\
\text { rads for } 5 \text { minutes }\end{array}$ & $\begin{array}{l}\text { Pathogen inactivation (including } \\
\text { viruses) }\end{array}$ \\
\hline Pasteurization & $\begin{array}{l}70^{\circ} \mathrm{C} \text { for } 45 \mathrm{~min}- \\
\text { utes }\end{array}$ & $\begin{array}{l}\text { Pathogen inactivation (including } \\
\text { viruses) }\end{array}$ \\
\hline
\end{tabular}


- Lime stabilization is another method used to eliminate pathogens present is sewage sludge. Battelle researchers (4) have shown that significant reductions in indicator and pathogenic bacteria can be achieved by lime treatment. Tests on fecal coliform, fecal streptocci, Salmonella species, and Pseudomonas aeruginosa were conducted. At $\mathrm{pH} \geq 12.0$ al1 were inactivated after $1 \mathrm{hr}$ of contact time. This was accompanied by a drop in pH. High pH maintenance can be obtained by overdosing with lime. When large concentrations of both hydroxyl ions and undissociated $\mathrm{Ca}(\mathrm{OH})_{2}$ are present in the system, sufficient $\mathrm{OH}^{-}$species exist to allow chemical reactions to proceed without an attendant decrease in $\mathrm{pH}$. Unfortunately, this high-pH-sludge tends to increase the soil $\mathrm{pH}$. This may cause problems if excessive quantities of 1 ime treated sludge are spread on agricultural land.

- Thermal conditioning, flash drying and incineration are processes that disinfect as a result of their high operating temperature $\left(>150^{\circ} \mathrm{C}\right)$. Table 7 shows the time-temperature relationship necessary for destruction of some pathogens. Both thermal conditioning and flash drying consistently produce a sludge devoid of pathogens. Incineration leaves an inert, disinfected ash.

- Static pile composting is an effective means of reducing the pathogens in sludge. Tests ${ }^{(6)}$ show large reductions in numbers of fecal and total coliforms and usually show elimination of any salmonella bacteria. As seen in Table 8 pathogen survival in composted sludge is highest in the lower corner of the compost pile (Location 4). From time to time it is possible to locate salmonella in low numbers in compost. However, Dr. S. D. Burge, a research microbiologist with the U.S. Department of Agriculture, reported $(7)_{\text {there is more }}$ danger from salmonella when food is left at room temperature or when walking in a park where dogs are given free rein than from compost. Dr. Burge has also performed experiments $(7)$ using F-2 phase as an indicator innoculating a gram of compost with $10^{7}$ virus particles. These were destroyed by the greater than $66^{\circ} \mathrm{C}$ temperatures 
generated during the 7-week composting period. From Reference 7 the consensus of researchers is that compost is virtually free from coliform, fecal coliform, salmonella, viruses, secondary funga 1 pathogens and ascaris ova.

TABLE 7. Temperature and Time for Pathogen Destruction in Sludges (Source: Reference 5)

Microorganisms

Cysts of Entamoeba Histolytica

Eggs of Ascaris Lumbricoides

Brucella Abortus, Brisuis

Corynebacterium Diptheriae

Sa 1monella Typhi

Salmonella sp.

Escherichi Coli

Micrococcus Pygogenes Var. Aureus

Mycobacterium Tuberculosis Var.

Hominis

Viruses

Shigella sp.

Taenia

Trichinella Spiralis Larvae

Streptococcus pyogenes
Exposure Time (Minutes) for Destruction at Various Temperatures $\left({ }^{\circ} \mathrm{C}\right)$

$\begin{array}{rc}50 & \frac{55}{5} \\ & \text { few seconds } \\ & 7 \\ & 60\end{array}$

45

30

60

60 60 $\underline{65} \quad \underline{70}$

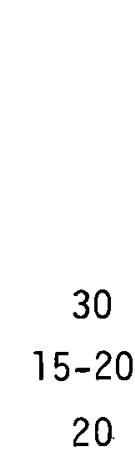
3

4 5 few minutes

few seconds instantly

10

- Disinfection by sludge lagoons has not been studied sufficiently to report quantitative data. Lagoons have been reported to get a strong, consistent reduction in pathogens when temperatures are near $20^{\circ} \mathrm{C}$ (G. Stern, Environmental Protection Agency). 
TABLE 8. Bacteria Concentrations in Static-Pile Composted Raw and Digested Sludge (cells/g) (Source: Reference 6)

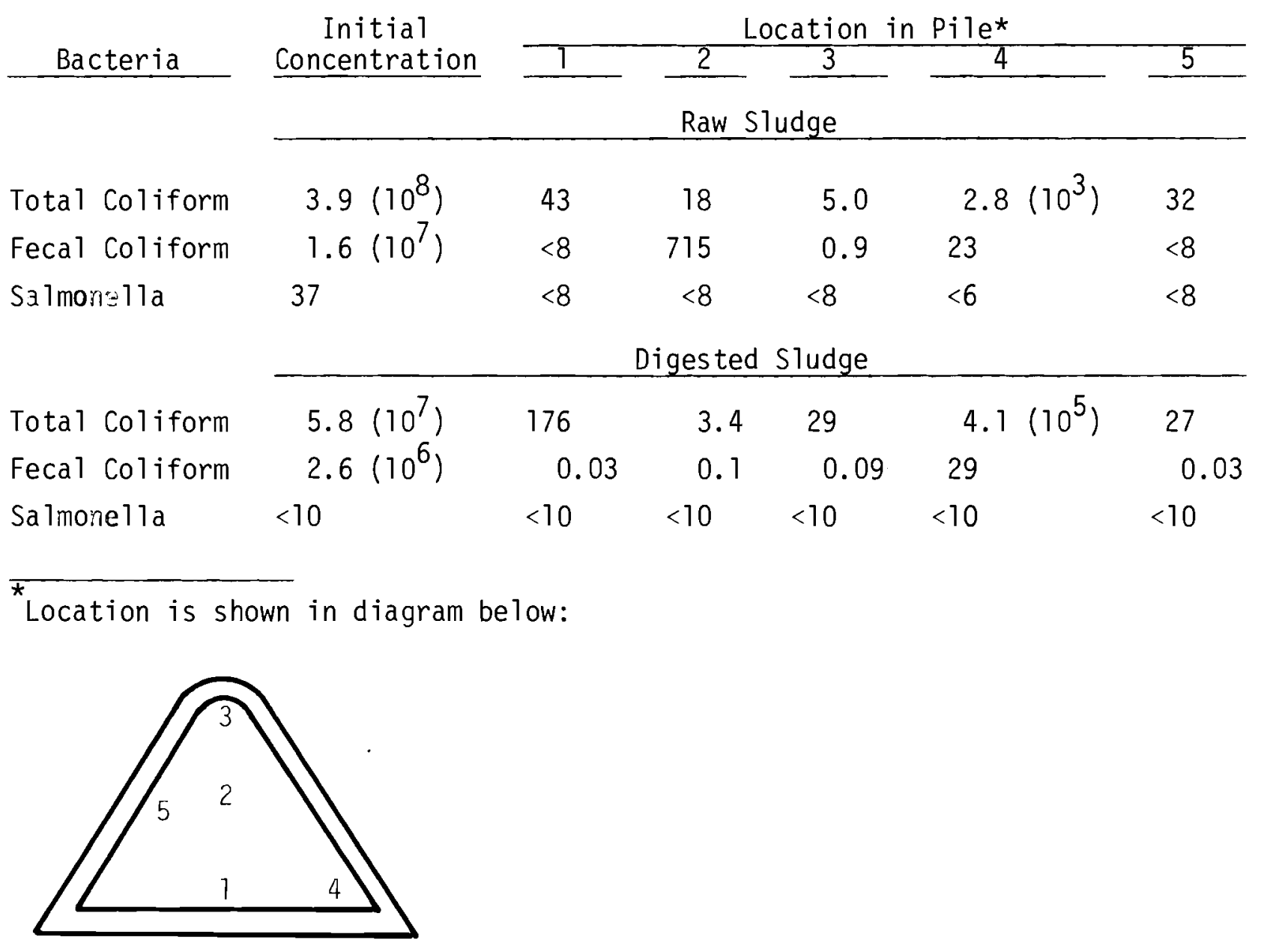

- Sludge irradiation. Experiments ${ }^{(8)}$ examining the biological effects of sludge irradiation indicate that it is extremely effective for the destruction of pathogenic bacteria. "Colony-forming-ability" was used to measure survival of coliforms, salmonellas, and fecal streptococcus bacteria. Reduction in embryonation ability was used to indicate inactivation of Ascaris lumbricoides. Table 9 shows the population reductions achieved by exposing the bacteria to an absorbed dose of 1 Megarad (Mrad) at $23^{\circ} \mathrm{C}$ (radiation treatment) or $300 \mathrm{kilorads}$ (krads) at $55^{\circ} \mathrm{C}$ (thermoradiation). 
TABLE 9. Effectiveness of Sludge Irradiation

for Bacteria Inactivation

(Source: Reference 11)

\begin{tabular}{|c|c|c|}
\hline \multirow[b]{2}{*}{ Organism } & \multicolumn{2}{|c|}{ Number Logs Reduced } \\
\hline & Radiation Treatment & Thermoradiation \\
\hline Coliforms & $>15$ & $>15$ \\
\hline Fecal Strep & $>10$ & $>7$ \\
\hline Salmonella & $>15$ & $>15$ \\
\hline Ascaris Ova & $>15$ & $>15$ \\
\hline
\end{tabular}

Radiation was not very effective on the virus population. (9) Sewage sludge seeded with attenuated polio virus and exposed to 1 Mrad saw a $<2$ log reduction in the virus population. When the sludge was heated to $55^{\circ} \mathrm{C}$ and exposed to a $300 \mathrm{krad}$ source the log reduction was $>9$. (9) Thus, thermoradiation is generally effective because the heat kills the viruses. Studies $(10)$ with T4 bacteria phase show essentially complete inactivation with thermoradiation treatment.

- Pasteurization is the last sludge treatment process with disinfection abilities considered in this report. Pasteurizing at $70^{\circ} \mathrm{C}$ for 45 min would destroy all the microorganisms listed in Table 7. Research studies ${ }^{(12)}$ have shown that $70^{\circ} \mathrm{C}$ for 30 to 60 min destroys pathogens in digested liquid sludge. Tentative EPA guidelines and California State Department of Public Health guidelines imply that $70^{\circ} \mathrm{C}$ for $30 \mathrm{~min}$ is sufficient for pasteurization.

$\underline{O D O R}$

The effect of any sludge stabilization process on odor is significant in the analys is of sludge treatment alternatives. Odors are the result of decomposition of the organic material in the sludge. Odor is eliminated or inhibited by controlled biological degradation or chemical stabilization of the organic matter. Also, physical attack on the microorganisms causing the degradation of the organic matter should reduce odor. 
Table 10 lists the effects of the various treatment alternatives on odor. The investigation of available literature indicates a substantial variation in absolute numbers relating the threshold numbers. This is because tests that quantitatively measure odor are subject to inaccuracies since the panels which do the testing are randomly selected. Therefore, in comparing odor effects, the relative change in odor versus a control sample is taken into account in Table 10.

TABLE 10. Odor Effects of Sludge Treatment Alternatives

\begin{tabular}{|c|c|c|}
\hline Treatment Process & Odor & $\begin{array}{c}\text { Improvement } \\
\text { Threshold Odor } \\
\text { Number } \\
\end{array}$ \\
\hline Anaerobic Digestion & + & $3^{x}$ \\
\hline Lime Stabilization & + & $+10^{x}$ \\
\hline Sludge Lagoons & $0 /-$ & \\
\hline Pasteurization & $0 /-$ & Qualitative \\
\hline Irradiation & $0 /-$ & $-3^{x}$ \\
\hline Thermoradiation & $0 /-$ & $-3^{x}$ \\
\hline Composting & + & Qualitative \\
\hline $\begin{array}{l}+ \text { Improved } \\
0 \text { No Difference } \\
\text { - Worse }\end{array}$ & & \\
\hline
\end{tabular}

In the following text odor effects and various treatment processes are compared.

- The odor level of thermophilically digested sludge is approximately the same as that of mesophilically digested sludge (W. Garber, Principal Sanitary Engineer for the City of Los Angeles). The literature ${ }^{(13)}$ indicates that mesophilic digestion improves on the threshold odor limit of raw sludge about threefold. However, the residual volatile acids, an important source ofi odor, are somewhat higher in thermophilic digestion. 
- The value of anaerobic lagoons as an odor eliminating practice is questionable. Numerous sources indicate the inadvisability of using lagoon storage unless it follows anaerobic digestion because of severe odor problems caused by the uncontrolled decomposition of the organic sludge. This evidence indicates that anaerobic lagoons do not significantly improve the odor of raw sludge. This indicates a very important point in the biological stabilization of organic wastes. Controlled degradation can eliminate or lessen odor problems. Uncontrolled degradation can cause more odor problems than originally existed.

- Lime stabilization reduces threshold odor levels tenfold. (4) This is achieved through the creation of a high pH, hostile environment in the sludge, thus eliminating or suppressing the growth of microorganisms that produce nuisance conditions. Additional studies are needed to determine if odor problems return when the $\mathrm{pH}$ is allowed to return to a level more attractive to microbiological growth.

- Pasteurization, irradiation, and thermoradiation all physically destroy or inactivate the organisms responsible for degradation. Odor problems should be lessened because of this physical destruction. However, this is not the case.

- No qualitative odor evaluations were found on pasteurization. However, on a qualitative basis, Sandia personnel reported that they found the odor of pasteurized sludge to be worse than that of raw or digested sludge. A qualitative study performed by Battelle showed that the relative odor ievel of raw and pasteurized sludge was essentially the same.

- Studies at Battelle $\mathrm{l}^{(13)}$ reported that irradiated and thermoirradiated sludge had a threefold higher odor threshold number than raw sludge. This result is surprising. The destruction of organisms should slow the odor-producing decomposition of the sludge. Further studies are needed to determine the reason for the increased odor. 


\section{HEAVY METALS AND SLUDGE REUSE}

Sewage sludges are known to contain trace amounts of a wide spectrum of naturally occurring elements. Some of these elements can be toxic to humans if they accumulate in the food chain. Elements of primary concern are the heavy metals cadmium, copper, lead, nickel, and zinc. Table 11 indicates the concentration of 13 metals in over 100 sludge samples from 32 wastewater treatment plants. Table 12 compares the amounts of trace elements in wastewater sludges with amounts naturally occurring in soils. It also predicts the increase in concentration as a result of adding 100 metric tons of sludge to soil.

The availability of heavy metals in sludge to crops depends on soil pH and cation exchange capacity, phosphorus, calcium, organic matter, and crop variety, species, origin and age. Furthermore, the heavy metal content in sludges can vary widely from treatment plant to treatment plant. Therefore, it is extremely difficult to quantify on a national basis the quality of the treated sludge product with regard to metal content. Most of the states do have, or are in the process of formulating, regulations controlling the quantities of the known toxic metals that could be applied on the land. California has suggested limiting cadmium concentration to $25 \mathrm{ppm}$. Many of the sludge based soil conditioners currently on the market exceed this limit. Therefore, the success of a sludge reuse program may hinge on heavy metal concentration.

There are several research projects currently underway in the United States investigating heavy metal removal. No reduction in heavy metal content has been observed from radiation treatment. Municipalities mav be able to stop the discharge of some heavy metals (e.g. cadmium) into sewerage systems by eliminating the industrial source. However, positive action must be taken or the widespread reuse of sludge will be restricted in spite of the level of disinfection. 
TABLE 11. Average Concentrations of Metal in Raw Sludge and Digested Sludge(a) (Source: Reference 5)

\begin{tabular}{|c|c|c|c|c|c|}
\hline \multirow[b]{2}{*}{ Metal } & \multicolumn{2}{|c|}{ Arithmetic } & \multicolumn{2}{|c|}{ Geometric } & \multirow[b]{2}{*}{$\begin{array}{c}\text { Median } \\
\text { (50\% Value) } \\
\end{array}$} \\
\hline & Mean & $\begin{array}{l}\text { Std. Dev. } \\
1+\text { and }-1\end{array}$ & Mean & $\begin{array}{l}\text { Std. Dev } \\
(\div \text { and } x)(b)\end{array}$ & \\
\hline \multicolumn{6}{|l|}{$\begin{array}{l}\text { Raw } \\
\text { Sludge }\end{array}$} \\
\hline Silver & 490 & 370 & 355 & 2.51 & $>100$ \\
\hline Boron & 880 & 410 & 775 & 1.67 & 805 \\
\hline Cadmium & 30 & 15 & 27 & 1.53 & 20 \\
\hline Calcium & 13,800 & 7,830 & 11,700 & 1.82 & 13,900 \\
\hline Chromium & 1,370 & 1,400 & 940 & 2.75 & 750 \\
\hline Cobalt & 700 & 770 & 410 & 2.32 & 240 \\
\hline Copper & 860 & 550 & 740 & 1.67 & 660 \\
\hline Mercury & 15 & 23 & 8.2 & 2.54 & 5.5 \\
\hline Manganese & 1,310 & 2,860 & 460 & 3.32 & 200 \\
\hline Nickel & 580 & 540 & 420 & 2.12 & 335 \\
\hline Lead & 1,380 & 775 & 1,150 & 1.95 & 1,150 \\
\hline Strontium & 190 & 75 & 175 & 1.45 & $<100$ \\
\hline Zinc & 1,960 & 1,000 & 1,740 & 1.66 & 1,880 \\
\hline \multicolumn{6}{|l|}{$\begin{array}{l}\text { Diges ted } \\
\text { Sludge } \\
\end{array}$} \\
\hline Silver & 250 & 230 & 190 & 1.99 & 100 \\
\hline Boron & 430 & 310 & 380 & 1.58 & 350 \\
\hline Cadmium & 75 & 104 & 43 & 2.47 & 31 \\
\hline Calcium & 36,500 & 23,800 & 31,100 & 1.77 & 30,000 \\
\hline Chromium & 1,860 & 1,920 & 1,050 & 3.22 & 1,100 \\
\hline Cobalt & 350 & 220 & 290 & 1.88 & $<100$ \\
\hline Copper & 1,590 & 1,670 & 1,270 & 1.95 & 1,230 \\
\hline Mercury & 10 & 18 & 6.5 & 2.34 & 6.6 \\
\hline Manganese & 1,300 & 2,290 & 475 & 3.67 & 380 \\
\hline Nickel & 680 & 620 & 530 & 1.88 & 410 \\
\hline Lead & 2,750 & 2,350 & 2,210 & 1.82 & 830 \\
\hline Strontium & 250 & 670 & 290 & 2.70 & 175 \\
\hline $\operatorname{Zinc}$ & 4,210 & 3,800 & 2,900 & 2.40 & 2,730 \\
\hline
\end{tabular}


TABLE 12. Comparison of Amounts of Trace Elements in Wastewater Sludges and Soils (Source: Reference 5)

\begin{tabular}{|c|c|c|c|c|}
\hline \multirow[b]{2}{*}{ Element } & \multirow[b]{2}{*}{$\begin{array}{l}\text { Concentration } \\
\text { in sludge ug/g } \\
\end{array}$} & \multirow[b]{2}{*}{$\begin{array}{r}\text { Amount Applied } \\
\text { to Soil } \mathrm{kg} / \mathrm{ha}(\mathrm{a}) \\
\end{array}$} & \multicolumn{2}{|c|}{$\begin{array}{l}\text { Amount present in } \\
\text { soil, } \mathrm{kg} / \mathrm{ha}\end{array}$} \\
\hline & & & $\begin{array}{c}\text { Norma } 1 \\
\text { Range } \\
\end{array}$ & $\begin{array}{l}\text { Typical } \\
\text { Level }\end{array}$ \\
\hline Arsenic & 5 & 0.5 & $0.2-80$ & 12 \\
\hline Barium & 1,000 & 100 & $200-6,000$ & 1,000 \\
\hline Boron & 50 & 5 & $4-200$ & 20 \\
\hline Cadmium & 10 & 1 & $0.2-1.4$ & 0.12 \\
\hline Chromium & 200 & 20 & $10-6,000$ & 200 \\
\hline Cobalt & 10 & 1 & $2-80$ & 16 \\
\hline Copper & 500 & 50 & $4-200$ & 40 \\
\hline Lead & 500 & 50 & $4-400$ & 20 \\
\hline Manganese & 500 & 50 & $200-8,000$ & 1,700 \\
\hline Mercury & 5 & 0.5 & $0.02-0.6$ & 0.06 \\
\hline Molybdenumn & 5 & 0.5 & $0.4-10$ & 4 \\
\hline Nicke 1 & 50 & 5 & $20-2,000$ & 80 \\
\hline Selenium & 1 & 0.1 & $0.02-4$ & 0.4 \\
\hline Silver & 10 & 1 & $0.02-10$ & 0.2 \\
\hline Tin & 100 & 10 & $4-400$ & 20 \\
\hline Vanadium & 50 & 5 & $40-1,000$ & 200 \\
\hline Zinc & 2,000 & 200 & $20-600$ & 100 \\
\hline
\end{tabular}

(a) Assuming 100 metric tons of a domestic sludge is mixed to a depth of $15 \mathrm{~cm}$ and the bulk density of the soil is $1.33 \mathrm{~g} / \mathrm{cm}^{3}$. 


\section{POTENT IAL PRODUCT VALUE}

During the course of this study it has been assumed that dried sludge has a marketable value as a soil conditioner or fertilizer. This value may be based on price levels for commercial fertilizer or on the receipts from current sales of dried sludge.

Table 13 indicates approximate price levels for commercial fertilizer. Bas d on these price levels and assuming various concentrations of nitrogen, phosphorous, and potassium in sludge, the economic value of the nutrients in sludge was calculated ${ }^{(5)}$ with results shown in Table 14 . This evaluation assumes that all nutrients have a value, which may not be the case in reality. For example, if the sludge is applied to satisfy the nitrogen requirement, then excess potassium should have no dollar value.

During 1975 and 1976 the firm Culp/Wesner/Culp conducted surveys for the U.S. Environmental Protection Agency to determine user acceptance of sewage sludge. The results indicated that the upper price limit for bulk sewage sludge would be $\$ 4-\$ 10 /$ ton and for packaged sewage sludge about $\$ 60 /$ ton at the point of sale based on West coast price levels. Historical sludge prices are shown in Figure 9.

TABLE 13. Assumed Prices for Fertilizer Nutrients, Approximately 1976

Dollars (Source: Reference 5)

\begin{tabular}{llccc} 
& \multicolumn{3}{c}{$\begin{array}{c}\text { Price Range } \\
\text { (Dollars/Pound) }\end{array}$} \\
\cline { 1 - 1 } \multicolumn{1}{c}{ Nutrient } & & High & Medium & Low \\
N (Nitrogen) & & 0.30 & 0.20 & 0.10 \\
$\mathrm{P}_{2} \mathrm{O}_{5}$ (Phosphate) & 0.25 & 0.20 & 0.15 \\
$\mathrm{~K}_{2} \mathrm{O}$ (Potash) & 0.12 & 0.10 & 0.08
\end{tabular}


TABLE 14. Value of Nutrients in 1 Ton of Dry Sewage Sludge Assuming Various Nutrient Contents and Commercial Fertilizer Prices* (Source: Reference 5)

ivutrient Content

Low $\left(\mathrm{N}=2.0 \%, \mathrm{P}_{2} \mathrm{O}_{5}=1.1 \%, \mathrm{~K}_{2} \mathrm{O}=0.12 \%\right)$

Medium ( $\left.N=3.3 \%, P_{2} O_{5}=5.3 \%, K_{2} 0=0.4 \%\right)$

High ( $\left.\mathrm{N}=5.0 \%, \mathrm{P}_{2} \mathrm{O}_{5}=9.2 \%, \mathrm{~K}_{2} \mathrm{O}=2.4 \%\right)$
Value of Nutrients

in Sludge**

High Medium Low

$\$ 9.80 \$ 7.30 \$ 4.80$

$34.00 \quad 26.40 \quad 18.70$

$61.70 \quad 48.20 \quad 34.70$

* It is assumed that one-third of the total $N$ would be immediately available to crops while all of $\mathrm{P}_{2} \mathrm{O}_{5}$ and $\mathrm{K}_{2} \mathrm{O}$ would be available.

** Based on three different levels of fertilizer prices as shown in Table 13. 


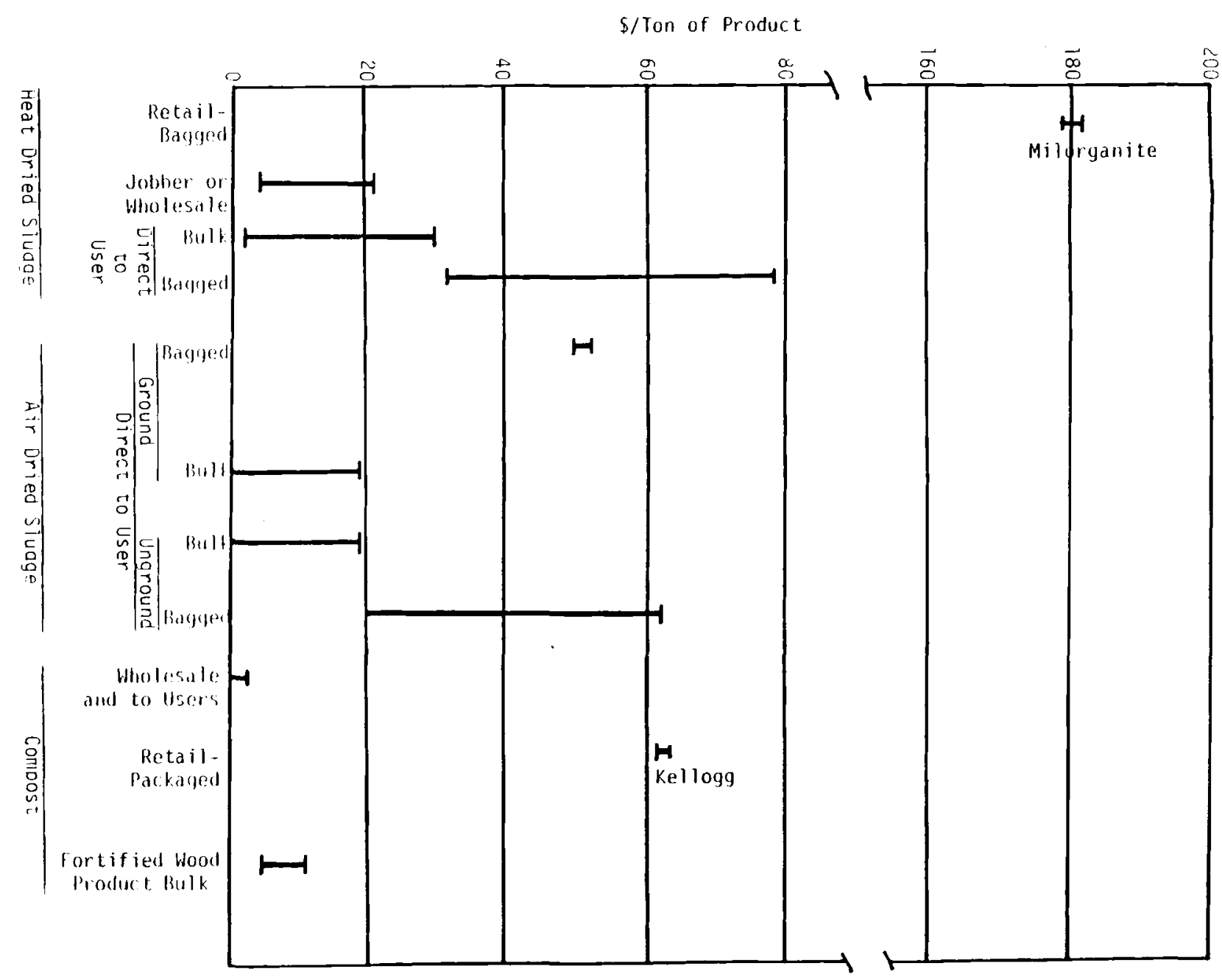

FIGURE 3. Historical Sludge Sales Prices (1960-1975) (Source: Reference 14) 


\section{RADIATION TREATMENT COSTS AND BENEFITS}

The purpose of this section is to investigate the cost/benefit relationship developed when radiation is added to a sludge treatment scheme.

The general benefit of radiation is high pathogen destruction. This allows for a more widespread use of the irradiated sludge. However, treatment options that do not employ a stabilization process and produce a moist or wet sludge (Options $B_{1}, B_{21}, C_{8}$, and $C_{9}$ ) may not be able to capitalize on the benefit due to strong odor problems and pathogen growback potential. Sludge subjected to treatment schemes producing only $5 \%$ moisture (Options $A_{1}, A_{4}, A_{5}$ ) has probably already been disinfected sufficiently without being irradiated. The remaining options using radiation treatment benefit from the added disinfection. However, the cost of irradiating wet sludge is greater than pasteurization. Since the benefit of radiation treatment can be provided by thermal treatment at less cost, radiation is not a desirable method for treating wet sludge. Furthermore, the benefit of disinfecting wet sludge may be offset by problems with transport and pathogen growback.

Radiation is the least expensive option for a dry product if additional disinfection is required after composting. However, little incentive exists for irradiating sludge unless regulatory agencies restrict reuse to highly disinfected products. 


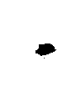

- 


\section{REFERENCES}

1. Estimated Costs of the B.E.S.T. System and Other Methods for Treatment and Use or Disposal of Municipal Wastewater Sludges. Prepared for Resources Conservation Company by Culp/Wesner/CuTp. Clean Water Consultants, El Dorado Hills, California 95630, January 1977.

2. Sludge Handling and Disposal, Phase I-State-of-the-Art. Prepared by Stanley Consultants, Inc. for the Metropolitan Sewer Board, St. Paul, Minnesota 55101, November 15, 1972.

3. Progress Report-Beneficial Uses Program. Period Ending June 30, 1976. SAND 76-0511. Report to U.S. Energy Research and Development Administration by Sandia Laboratories, Albuquerque, New Mexico 87115, 1976.

4. C. A. Counts and A. J. Shuckrow, Lime Stabilized Sludge: Its Stability and Effect on Agricultural Land. Report to U.S. Environmental Protection Agency, prepared by Battelle, Pacific Northwest Laboratories, Richland, Washington 99352, November 1974.

5. R. T. Haug, L. D. Tortorici, and S. K. Raksit. Sludge Processing and Disposal, A State of the Art Review. LA/OMA Project, Los Angeles/Orange County Metropolitan Area, Whittier, California 90607, April 1977.

6. E. Epstein et a1., "A Forced Aeration System for Composting Wastewater Sludge," J. Water Pollution Control Federation. 48(4):688-694, Apri1 $197 \overline{6 .}$

7. K. T. Doty, M. M. Varma, P. C. Kumar, Composting Raw Sludge Nears Optimal Waste Utilization. Washington Suburban Sanitary Commission, Hyattsvil1e, Maryland 20781, February 1977.

8. J. R. Brandon and S. L. Langley, Inactivation of Bacteria in Sewage Sludge by Ionizing Radiation, Heat, and Thermoradiation. SAND 75-0168. Report to U.S. Energy Research and Development Administration by Sandia Laboratories, Albuquerque, New Mexico 87115, January 1976.

9. M. E. Morris. "Cost Effectiveness Comparisions of Various Types of Sludge Irradiation and Sludge Pasteurization Treatments," Proceedings of the Third National Conference on Sludge Management Disposal and Utilization. Miami Beach, Florida, 1976.

10. R. L. Ward. "Inactivation of Anteric Viruses in Wastewater Sludge," Proceedings of the Third National Conference on Sludge Management Disposal and Utilization. Miami Beach, Florida, 1976.

11. J. R. Brandon. "Sandia's Sludge Irradiation Program," Proceedings of the Third National Conference on Sludge Management Disposal and Utilization. Miami Beach, Florida, 1976. 
12. G. Stern. "Pasteurization of Liquid Digested Sludge," Proceedings of the National Conference on Municipal Sludge Management. Pittsburgh, Pennsylvania, 1974.

13. D. Cash and P. Molton. Odor Assessment for Sewage Sludge Samples, BNWL-2177, Battel le, Pacific Northwest Laboratories, Richland, Washington 99352, December 1976.

14. W. F. Ettlich. "Wastewater Sludge Composting: the Market," Proceedings of the Third National Conference on Sludge Management Disposal and Utilization. Miami Beach, Florida, 1976. 
APPENDIX A

TECHNICAL DESCRIPTIONS OF MUNICIPAL SLUDGE TREATMENT PROCESSES 
APPENDIX A

TECHNICAL DESCRIPTIONS OF MUNICIPAL SLUDGE TREATMENT PROCESSES

\section{ANAEROBIC DIGESTION}

Anaerobic digestion is a two-phase biochemical process in which microorganisms assimilate and break down organic matter. In the first phase, complex organic materials are converted to simpler organic materials and then to short chain organic fatty acids. The facultative and anaerobic bacteria that accomplish this are called "acid formers". In the second phase, strictly anaerobic bacteria called "methane formers" convert the organic acids into gaseous products, primarily methane and carbon dioxide.

Anaerobic digestion is an old process. The Imhoff process and the backyard septic tanks are two examples of anaerobic treatment used for many years. 01d conventional digesters were usually unmixed, with sludge pumped into the middle. The stabilized solids settle to the bottom and are removed while the supernatant is drawn off the top. The active layer in the center of the tank is the prime area of anaerobic degradation. Newer high rate anaerobic digestion units are usually completely mixed, either mechanically or by the recycling of compressed digester gas. This increases the active area of decomposition and significantly increases the rate of stabilization. Additionally, a second, unmixed digester can be used in series with the mixed digester to accomplish two-stage digestion. The second-stage digester serves to collect gas, return supernatant to the head works of the plant and separate digested sludge. Two-stage digestion is not yet a common practice.

The digesters are usually heated to allow the biological degradation to proceed in either the mesophilic or thermophilic temperature range. The methane gas production from the system is a useful by-product which can be used either onsite or offsite. 


\section{LIME STABILIZATION}

Lime has been used in the past to eliminate nuisance conditions resulting from open pit latrines and burial sites for domestic animals. Farrel

et al. (1) found that the addition of lime to be effective in both deodorization and disinfection. Battelle-Northwest conducted a study in $1974^{(2)}$ which yielded similar results.

In the Battelle study, lime was added to raw sludge to bring the $\mathrm{pH}$ up to 12.0. The sufficient lime dose for sludge stabilization proved to be dependent on $\mathrm{pH}$ and not on the number of organisms present. The high $\mathrm{pH}$ sludge is unable to sustain microbiological growth. Care is taken to ensure that the lime dose is sufficient to prevent the $\mathrm{pH}$ from dropping to lower levels. Studies $(1,2)$ have shown that the degree of $\mathrm{pH}$ decay over time is lowered significantly if the initial $\mathrm{pH}$ of the sludge is above 12.0. The results at Battelle indicated that pathogen kill was substantial, odor problems significantly decreased, and sludge dewaterability improved.

A typical system treats raw sludge at 1 to $5 \%$ solids. Sufficient lime is added in a rapid mixer to raise the $\mathrm{pH}$ above 12.0. The treated sludge is placed into a contact tank for a period of time to stabilize the sludge at the elevated $\mathrm{pH}$. The sludge is then removed and either dried for further use or disposed of directly.

\section{THERMAL CONDITIONING}

Thermal conditioning by the low pressure wet air oxidation process utilizes the principle that any substance capable of burning can be oxidized. This is usually done in the presence of oxygen and liquid water at temperatures between 176.7 and $204.4^{\circ} \mathrm{C}$. The degree of oxidation depends on the temperature, pressure, feed solids concentration, and amount of air or oxygen supplied. The process does not require preliminary dewatering or drying and thus can operate on difficult to dewater waste liquors and sludges where the solids are but a few percent of the water streams. Water can be present up to $99 \%$ in this process. By operating at lower temperatures and pressures, the same approach may be used for sludge conditioning. 
Commercialized and patented as the Zimpro process, wet air oxidation has also been known as wet incineration, wet combustion, and wet oxidation. In the continuous process, sludge is passed through a grinder which reduces large particles to a maximum $1 / 4 \mathrm{in}$. size. Air is then pumped into the sludge and the mixture is passed through heat exchangers and brought to the initiating reaction temperature. As the mixture moves into the reactor, oxidation takes place and the temperature increases. After 15 to 60 minutes, the oxidized products leave the reactor to be cooled in heat exchangers against the entering cold sludge and air. The oxidized liquid and remaining suspended solids are released through a level control valve and the solids may be separated by settling and drainage in decant tanks, lagoons or sandbeds, or by other methods such as vacuum filtration or centrifugation.

With wet air oxidation, air pollution is minimized because the oxidation takes place in water at low temperatures and no fly ash, dust, sulfur dioxide, or nitrogen oxides are formed. The gases that do result are separated from the liquid and released through a pressure control valve to a catalytic oxidation unit for odor control. Where economic conditions make it attractive, the gases may be expanded in power recovery equipment before being discharged.

\section{VACUUM FILTRATION}

Vacuum filtration is a continuous process consisting of a rotating drum which continuously passes through a trough or pan containing the feed sludge. The cylindrical drum which is covered with some type of filter media is submerged about 20 to $40 \%$ in the trough. Radial partitions divide the filter drum into compartments, each alternately subjected to pressure and suction during each revolution. As a vacuum normally ranging from 24 to 28 in. of mercury is applied, sludge cakes on the filter media. This is known as the pickup portion of the cycle. As a point on the drum rotates out of the trough, the vacuum is decreased to between 20 and 26 in. of mercury. This represents the drying portion of the cycle. The filter cake is subsequentiy scraped off via blades or rollers. The separated water (filtrate) collected during the cycle is discharged to a drainage system. 


\section{FILTER PRESSING}

Filter pressing is a batch operation and achieves solids-liquid separation through use of a porous media under pressure. The press consists of a number of verticle plates or trays which are held rigidly in a frame and pressed together. A filter cloth is mounted on the face of each individual plate.

During filtration, sludge is fed into cavities between the trays. The water passes through the fibers of the filter cloth and solids are returned. sludge feeding stops when the cavities are completely filled. When the filtrate flow is near zero, the plates are disengaged and the filter cake discharged to a hopper or conveyor beneath the unit.

\section{$\underline{\text { FLASH DRYING }}$}

A flash dryer consists of a pneumatic-conveyor employing hot gas as the conveying medium. (3) The moist sludge is mixed with hot gases from the furnace at about 650 to $760^{\circ} \mathrm{C}$. Vaporization of the water begins as the mixture enters a cage mill. The cage mill mechanically agitates the sludge-gas mixture exposing the maximum sludge surface area to the hot gas. Retention time in the cage mill is a matter of seconds. The dried sludge is separated from the spent drying gases in a cyclone. The heat dried sludge exits the cycione at about $70^{\circ} \mathrm{C}$.

\section{INCINERATION}

Sludge incineration is a drying and combustion process used to reduce the volume of wastewater solids as well as minimize their environmental impact. Characteristic phases in this process include: a) raising the temperature of the feed sludge to $100^{\circ} \mathrm{C}$, b) evaporating water from the sludge, c) increasing the water vapor and air temperature of the gas, and d) increasing the temperature of the dried sludge volatiles to the ignition point. The drying and combustion procedure may take place in separate units or successively in the same unit. Fuel, air, time, temperature, and turbulence are all necessary for a complete reaction. 
There are several types of incinerators being used throughout the world. The two major incineration systems employed in the United States are the multiple hearth furnace and the fluidized bed incinerator.

The multiple hearth furnace is the most widely used wastewater sludge incinerator because it is simple, durable, and has the flexibility of burning a wide variety of materials even with fluctuations in the feed rate. It is composed of a number of circular refractory hearths stacked one above another and a central rotating shaft to which rabble arms are attached. The dewatered sludge is fed into the top hearth and moved by the rotary action of the rabble arms. Rabble arms have inclined teeth that plow the sludge, exposing fresh surfaces to hot gases. The plowing action also moves the sludge to ports leading to successively lower hearths. The sludge dries in the upper hearths, burns in the middle hearths, and cools as ash in the lower hearths. Capacities of multiple hearth incinerators vary from 200 to $8,0001 \mathrm{~b}$ of dry sludge per hour with operating temperatures as high as $925^{\circ} \mathrm{C}$.

The fluidized bed incinerator is a newer process for sludge incineration than the multiple hearth furnace. It consists of a vertical refractory-lined cylindrical shell with a grid in the lower section to support a sandbed. Dewatered sludge is injected above the grid and combustion air flows upward at a pressure of 3.5 to 5.0 psig and fluidizes the mixture of hot sand and sludge. Both moisture evaporation and combustion occur at 760 to $815^{\circ} \mathrm{C}$ in the sandbed. A fluidized bed incinerator can be operated 4 to 8 hours a day with little reheating when restarting because the sandbed serves as a heat reservoir.

It is important to obtain a maximum solids concentration prior to sludge incineration. This will aid in high temperature combustion of products and moisture. Temperatures of 730 to $760^{\circ} \mathrm{C}$ are generally accepted as necessary to insure deodorization of the stack gases of a conventional incinerator. The heat required to evaporate the water nearly balances the available heat from combustion of the dry solids when a sludge with a moisture content of about $75 \%$ is delivered to the incinerators. Heat from stack gases may be recovered to aid the incineration process by preheating the incoming furnace 
air or conditioning the incoming sludge to achieve a 30 to $40 \%$ solids concentration. Incineration may be self-sustaining if sufficient heat is available in the stack gases.

The combination of sludge and municipal refuse is another way to enhance incineration. Sludge with $5 \%$ solids and $70 \%$ volatile solids would require $28 \%$ refuse to sustain combustion lassuming the heat value of the refuse to be $4,750 \mathrm{Btu} / 1 \mathrm{~b}$ and the moisture content $25 \%$ ).

\section{COMPOSTING}

Composting has been a common practice in rural areas of Europe and Asia for many years. The necessity for soil maintenance in heavily cultivated areas of these countries makes composting attractive. Because of the ready availability of commercial fertilizers, most composting operations in the United States have ended unsuccessfully. For example, compost plants in Largo, Florida; Houston, Texas, and Gainesville, Florida; all of which combined municipal refuse and sewage sludge, have been abandoned. (4) However, recent studies $^{(5)}$ at Beltsville, Maryland, by the Department of Agriculture, hold promise of more successful U.S. operations.

Composting is the aerobic biochemical degradation of the organic fraction of solid waste material. The product is a humus-like substance that is used primarily for soil conditioning. It entails the use of naturally occurring microorganisms.

Ideally, these microbes degrade the organic materials and raise the stable operating temperature above $45^{\circ} \mathrm{C}$. The operating temperature is controlled to a great extent by the oxygen present and/or the amount of aeration provided. Adequate ventilation must be provided to ensure the survival of the aerobic organisms. A good stable operating temperature would be in the range of 60 to $70^{\circ} \mathrm{C}$.

The static pile process currently in use at Beltsville has been very successful in composting raw sewage sludge without an odor problem. The static pile process uses a forced air ventilation system for control of the 
oxygen present in the compost pile. The pile then remains fixed, as opposed to the constant turning used in windrow composting, and the forced ventilation maintains aerobic conditions.

The feed to the process consists of raw sludge filter cake ( $23 \%$ solids) and wood chips at a 1:3 ratio on a volume basis. The pile is covered with screened compost to prevent odors from escaping into the atmosphere and to provide insulation for better heat maintenance. Oxygen content is held between 5 and 15\% in the pile. Suction is maintained for 16 to 20 days and air is then applied to the pile for 8 to 10 days. The exhaust in the first stage is discharged in a screened compost pile.

After stabilization, temperatures in the pile are between 65 to $70^{\circ} \mathrm{C}$. The sludge composts well and no odor problems have been encountered.

\section{SLUDGE LAGOONS}

Lagoons are natural or artificial depressions in the ground enclosed by an earth dike. The lagoon may be round, square, or rectangular and serve as a stage process in the handling of sludge or as a final disposal process. Operating liquid depths usually range between 1.5 and 10 feet with a 3 -foot freeboard.

Large and inexpensive land areas are required to justify lagooning. Frequently the lagoon area exceeds six acres. In such cases it is good practice to have multiple cells which can be operated individually, in series or parallel.

\section{RADIATION AND THERMORADIATION TREATMENT}

The purpose of radiation treatment is to inactivate pathogens in sewage sludge thereby making sludge more acceptable for beneficial reuse. The radiation treatment system consists of an radiation source, such as cobalt-60 or Cesium-137, in a tank. Sludge is passed near the source and the high energy gamma-rays effectively destroy the pathogens. One megarad of radiation is a typical dose. The sludge may exist in a liquid or dry state. The sludge does not become radioactive. 
Studies conducted at Sandia Laboratories in Albuquerque, New Mexico, have experimented with combining a smaller radiation dose and heat. The studies have shown that the combination reacts synergistically to give much better than predicted sludge disinfection. The dose was reduced to 300,000 rads and the sludge temperature raised to $55^{\circ} \mathrm{C}$. This "thermoradiation" process appears to improve the dewaterability of the sludge. Thermoradiation is usually applied to liquid sludge only due to the difficulties of heating dry sludge. There are no full-scale radiation or thermoradiation facilities operating in the United States.

\section{PASTEURIZATION}

Pasteurization is simply the heating of liquid sludge to a specific temperature for a period of time sufficient to destroy undesirable organisms in the sludge. Previous studies have shown pasteurization to be an effective method of destroying pathogens in sludge. The Environmental Protection Agency conducted one such study. ${ }^{(6)}$ The final results indicated that a temperature of $70^{\circ} \mathrm{C}$ for 30 to 60 minutes destroyed or inactivated virtually all pathogens and parasites.

In the pasteurization process, steam is usually produced in a steam boiler and used to heat the tank containing the sludge to the appropriate temperature. The sludge is kept completely mixed because the thermal conductivity of liquid sludge is low. Direct steam injection should be used if both organic fouling and inorganic scaling on the heat exchanger reduces the heat transfer efficiency. Also, heat recovery after pasteurization is difficult for these same reasons. There are no full-scale sludge pasteurization systems operating in the United States. 
APPENDIX B

COST DEVELOPMENT AND DESIGN CRITERIA FOR UNIT PROCESSES

USED IN MUNICIPAL SLUDGE TREATMENT 
APPENDIX B

COST DEVELOPMENT AND DESIGN CRITERIA FOR UNIT PROCESSES

USED IN MUNICIPAL SLUDGE TREATMENT

\section{COST DEVELOPMENT AND DESIGN CRITERIA}

Unit costs have been developed for each sludge treatment process described in Appendix $A$. Whenever possible only data based on actual plant construction and operation was used. Much of the data has been supplied by manufacturers of equipment utilized in the different processes. Previous cost studies were also frequently consulted. When no actual data was available, costs were based on preliminary engineering estimates.

The costs data for each unit process has been analyzed by the least squares method and best fit curves plotted. These curves, with the data points indicated, follow the text in this Appendix. Each treatment option derives its cost by summing the costs for each unit process used. It must be recognized that costs generated from statistical solutions of general data points can in no way substitute for cost estimating based on detailed knowledge of a particular sludge treatment situation. However, the method is useful in preliminary evaluations.

A11 costs in this report have been modified to reflect May 1977 dollars by using the Engineering News Record Construction Cost Index. Capital cost figures include $35 \%$ for engineering, legal and administrative services, interest during construction and contingencies. Land costs were amortized over an infinite period of time at $7 \%$ interest. Land costs were only assigned to sludge lagoons and composting. A value of $\$ 10,000$ per acre was assumed. Cesium-137 costs were amortized over 20 years at $0 \%$ interest. The remaining capital costs were amortized over 20 years at $7 \%$. The cost of housing is included in all estimates where housing of equipment may be needed. Yardwork necessary for interconnecting the various unit processes is not included in the cost curves. Unit prices used in preparing the estimates for this report are presented below: 


$\begin{array}{ll}\text { Plant Operator Labor and Supervision } & \$ 10 / \mathrm{hr} \\ \text { Electricity } & \$ 0.04 / \mathrm{kWh} \\ \text { Fuel } & \$ 2.00 / \mathrm{mi} 11 \text { ion Btu } \\ \text { Polymers } & \$ 1 / 1 \mathrm{~b} \\ \text { Lime } & \$ 28 / \text { ton } \\ { }^{137} \mathrm{Cs} & 10 \$ / \mathrm{Ci}\end{array}$

Sludge Quantity

The sludge characteristics shown in Table B-1 were used in developing the cost estimates for this report.

TABLE B-1. Sludge Characteristics Used in Cost Study

\section{Total}

Sludge

Volatile Solids, Total Solids, Solids, Total Sludge,

\begin{tabular}{|c|c|c|c|c|}
\hline Raw Sludge & $1 \mathrm{~b} / \mathrm{million}$ gal & $1 \mathrm{~b} / \mathrm{mill} 1 \mathrm{ion}$ gal & $\%$ & $1 \mathrm{~b} / \mathrm{milllion} \mathrm{ga}]$ \\
\hline Primary & 600 & 1,000 & & \\
\hline Waste Activated & 800 & 1,000 & & \\
\hline Total & 1,400 & 2,000 & 5.0 & 40,000 \\
\hline
\end{tabular}

Digested Sludge

Total

700

1,300

5.0

26,000

The above characteristics yield the sludge quantities indicated in Table B-2.

TABLE B-2. Sludge Quantities Used in Cost Study

\begin{tabular}{|c|c|c|}
\hline $\begin{array}{l}\text { Treatment Plant } \\
\text { Capacity } \\
\end{array}$ & $\begin{array}{l}\text { Raw Sludge } \\
\text { Flow, gpm } \\
\end{array}$ & $\begin{array}{l}\text { Digested Sludge } \\
\text { Flow, gpm }\end{array}$ \\
\hline $5 \mathrm{mgd}$ & 16.7 & 10.8 \\
\hline $50 \mathrm{mgd}$ & 167 & 108 \\
\hline $100 \mathrm{mgd}$ & 333 & 216 \\
\hline $200 \mathrm{mgd}$ & 666 & 433 \\
\hline
\end{tabular}




\section{Anaerobic Digestion}

Anaerobic digestion costs are based on data from References 7, 8 and 9. The costs assume two stage digestion with an unmixed secondary digester equal in size to the primary digester. Volumes were computed by the sidewater depth only. No allowance was made for conical bottoms and freeboards. Capital costs include the digester and control building structures, and sludge heating, circulating and control equipment. Piping within the structure is included, but not piping to and from the digesters. The largest practical volume of two digesters and a control building was assumed to be $400,000 \mathrm{ft}^{3}$. The cost per unit of digester volume decreases up to this size. For larger volumes, multiples of the digester and control building arrangement were assumed with no further reduction in unit cost.

Labor requirements include monitoring and control of the facilities and maintenance of the digester, control building, and equipment used in sludge digestion.

Material and supply costs are for maintenance of the structures and equipment; electric power for pumps, blowers and ventilation; and auxiliary fuel for heat exchangers.

Anaerobic digesters operating in the mesophilic range $\left(35^{\circ} \mathrm{C}\right)$ were designed for a 25-day digestion period. This was reduced to 16 days for digesters operating in the thermophilic range $\left(47.8^{\circ} \mathrm{C}\right)$. Thermophilic digesters were costed as mesophilic digesters with an allowance made for the additional stream required to raise the temperature to $48^{\circ} \mathrm{C}$. In calculating additional steam requirements, the minimum raw sludge temperature was assumed to be $17.8^{\circ} \mathrm{C}$. The heat lost through radiation was taken to be $33 \%$ for mesophilic digestion and $29 \%$ for thermophilic digestion. This is consistent with data from actual operation. (9)

No credit was taken for the digester gas produced. Table B-3 estimates the volume of gas produced and heat available from anaerobic digestion. 
TABLE B-3. Estimated Gas and Heat Available from Anaerobic Digestion

\begin{tabular}{lccr} 
& Primary Sludge & $\begin{array}{c}\text { Waste Activated } \\
\text { Sludge }\end{array}$ & Total \\
\cline { 2 - 3 } Gas Produced, scf per & 5,175 & 5,670 & 10,845 \\
million gallons treated & $3,105,000$ & $3,402,000$ & $6,507,000$ \\
Heat available, Btu per & & & \\
million gallons treated & & & \\
Source: Reference 10 & & & \\
Lime Stabilization
\end{tabular}

Lime stabilization costs were based on References 2 and 11 . The costs include lime storage and feeding, rapid mixing, and flocculation. Lime storage and feeding cost estimates were based on the use of hydrated 1 ime for plants using $50 \mathrm{lb} / \mathrm{hr}$ or less and pebble quick-lime for plants using more. The feed rates allow for peak rates equal to twice the average rate. Capital costs include feeding equipment, piping, building to house the feeding equipment, steel bins with dust collector vents, filling accessories, flow and $\mathrm{pH}$ metering equipment, and storage for a minimum of 15 days at the average feed rate.

Labor requirements were based on the use of slaked lime and account for unloading, slaking and feeding. Assumptions include $1 \mathrm{hr} / \mathrm{shift} / \mathrm{slaker}$ in use, $10 \mathrm{~min} / \mathrm{hr} /$ feeder, and $4 \mathrm{hr} / \mathrm{wk}$ for the slurry pot-feed 1 ine.

Power requirements include allowances for slakers, bin activators, grit conveyors, dust collection fans, slurry mixers, and slurry feed pumps.

Costs presented in this report assume a lime dose of $600 \mathrm{lb} /$ ton of suspended solids. This is sufficient to elevate the pH of a mixed primary and waste activated sludge to 12.4 (2)

The rapid mix basin was sized to allow $60 \mathrm{sec}$ of high velocity mixing. Capital costs assumed a reinforced concrete basin. The costs are applicable to a mean velocity gradient $(G)$ of $600 \mathrm{ft} / \mathrm{sec}-\mathrm{ft}$. 
Labor requirements include $1 \mathrm{hr} /$ day for jar tests, $15 \mathrm{~min} /$ day for routine operation and maintenance, $4 \mathrm{hr} /$ unit every 6 months for major $0 i 1$ changes, and an allowance for draining and cleaning each rapid mix basin once per month.

Power requirements are based on the motor size used. A mixer efficiency of $55 \%$ was assumed with the unit operating $8760 \mathrm{hr} /$ year.

The material and supply costs presented are based on $5 \%$ of the equipment costs.

Flocculation was assumed to occur in two parallel tanks. The tanks were of reinforced concrete design with a $1 \mathrm{hr}$ detention time. A 20\% allowance was included for excess capacity. The capital costs are based on a $G$ of $150 \mathrm{ft} / \mathrm{sec}-\mathrm{ft}$. Labor and power requirements were based on assumptions similar to those for rapid mixing. Maintenance material costs were assumed to be $3 \%$ of the equipment cost.

Therma 1 Conditioning

Thermal conditioning costs were based on data from Reference 8 . The low pressure wet air oxidation process was used to condition the sludge. Costs for this process are divided into three parts: 1) oxidation costs, 2) recycled liquor costs, and 3) odor control. The sludge flow was assumed to have an initial BOD of $250 \mathrm{mg} / \ell$. The thermal treatment unit operates $8000 \mathrm{hr} / \mathrm{yr}$ and achieves $5 \%$ oxidation.

The recycled liquor was assumed to have a BOD of $6500 \mathrm{mg} / \ell$ and a suspended solids concentration of $5000 \mathrm{mg} / \ell, 75 \%$ of which is volatile. Costs are based on the assumption that the treatment plant was fully loaded prior to the addition of the recycled liquor. Thus equipment and structures must be increased to accept the liquor remains while maintaining the same solids concentration and cell residence time. The BOD loading to secondary treatment is assumed to increase by $20 \%$.

Recycled liquor capital costs include expenses created by increasing the size of an activated sludge system using diffused-air for aeration. An allowance of $10 \%$ is also included to cover additional site work, yard piping, 
utilities, and support facility costs. No increase in cost was assumed for clarification, piping and pumping. The recycled liquor labor requirements show the additional manhours required for operating and controliing the secondary treatment and thickening processes, maintaining aeration equipment, and maintaining settling and pumping systems. The incremental material and supplies costs cover additional needs of materials such as paint, lubricants, bearings, air filters, lab supplies, replacement parts and other items normally required in a secondary treatment plant.

Chemical scrubbing for odor control represents costs necessary to treat concentrated, high-hydrocarbon gas streams coming from gas separators or covered decanting tanks. These costs do not include ventilating, heating, and air conditioning of the thermal treatment building.

Vacuum Filtration

Vacuum filtration costs are based on data found in Reference 8. Table B-4 indicates the design filter rate, percent solids in the filter cake and vacuum filter surface area assumed for each sludge type. A $20 \%$ excess capacity allowance was used when sizing the vacuum filter. The unit was assumed to operate $16 \mathrm{hr} /$ day. When vacuum filtration was preceded by radiation, thermoradiation or pasteurization, the percent solids in the filter cake was assumed to increase by 5 percentage points.

Capital costs include housing structures, auxiliary equipment, piping, and other normal costs associated with vacuum filters.

Labor requirements include filter start-up time, operation, and maintenance of the filters, cleanup after the filter run, operation of the sludge pumping and conditioning facilities prior to treatment, and conveyor operation.

Material and supplies costs includes chemicals for sludge conditioning prior to filtration, power, filter media, repair parts and miscellaneous supplies. 
TABLE B-4. Design Criteria for Vacuum Filter

Design Filter

Rate Percent Solids

Sludge Type (psf/hr) in Filter Cake

Filter Surface Area $\left(\mathrm{ft}^{2}\right)$

Mixed Primary

4.5

20

$167 \quad 1667$

33333

6667

and Activated

Therma 1

Conditioned

5.0

40

150

1500

3000

6000

Lime

Stabilized

4.5

30

200

2001

4002

8003

Mesophillic

Anaerobic

Digested

4.0

15

122

1219

2438

4875

Thermophillic

Anaerobic

Digested

4.5

25

$108 \quad 1083$

2167

4333

\section{Filter Pressing}

Filter press costs are based on data from Reference 8 . Capital costs recognize the fact that the largest single unit currently available has a capacity of $278 \mathrm{ft}^{3}$. Therefore, multiple units were employed for handling larger sludge volumes. Housing costs are included at $4500 \mathrm{ft}^{2} / \mathrm{fil}$ ter press. Installation labor was estimated to be $30 \%$ of the equipment cost.

Labor and power requirements are based on a continuous 7 day/week, $2 \mathrm{hr}$ cycle. The filter press volumes include a $20 \%$ allowance for downtime. The open and close mechanism and tray moving mechanism operates $2-1 / 2 \mathrm{hr} / \mathrm{day}$. The feed pump is the major power consumer.

Material and supply costs include chemicals, sidestream treatment, and maintenance materials. Chemical costs are based upon the use of $5 \% \mathrm{FeCl}_{3}$ and 10\% lime. All costs are indicative of achieving $40 \%$ solids in the filter cake and a density of $83 \mathrm{lb} / \mathrm{ft}^{3}$.

Flash Drying

Costs for flash drying are based on data from Reference 8. Capital costs include housing and equipment. Operation and maintenance costs include electricity, fuel ( 8 million Btu/ton), and miscellaneous maintenance expenses. 


\section{Incineration}

Incineration costs are based on data from References 8 and 12 . The sludge was assumed to be incinerated in a multiple hearth furnace.

No heat recovery techniques were implemented. Capital costs include the multiple hearth furnace, enclosing structure, gas scrubber and exhaust, ash handling, fuel systems, instrumentation, piping, and electrical facilities. A single incinerator was deemed sufficient for a small capacity installation. Larger installations would divide the capacity between two or more units.

Labor requirements include removal of ash from the incinerator building, man-hours required for proper care and repair of the incinerator and accessory equipment, and periodic repair or replacement of refractory material within the incinerator.

Power and fuel requirements were taken from manufacturer quotations. They include allowances for the furnace and after burner. The incineration characteristics assumed for calculating the fuel and power requirements are listed in Table B-5.

TABLE B-5. Characteristics for Calculating Fuel Consumption in a Multiple Hearth Incinerator

\begin{tabular}{|c|c|c|}
\hline & $80 \%$ Moisture & $65 \%$ Moisture \\
\hline Percent Volatile Solids in Sludge & 55 & 55 \\
\hline Sludge Heat Value (Btu/lb) & 10,000 & 11,500 \\
\hline Furnace off Gas Temperature $\left({ }^{\circ} \mathrm{F}\right)$ & 800 & 1,000 \\
\hline Afterburner Temperature $\left({ }^{\circ} \mathrm{F}\right)$ & 1,400 & 1,400 \\
\hline Scrubber Outlet Temperature $\left({ }^{\circ} \mathrm{F}\right)$ & 120 & 120 \\
\hline
\end{tabular}

Material and supply costs include repair materials, replacement of refractory, miscellaneous supplies, and contractual cost of ash removal from the plant site.

\section{Composting}

Static pile composting costs are based on work done by the Agricultural Research Service (ARS) at Beltsville, Maryland. The ARS supplied detailed 
annual costs for a 10-dry-ton-per-day sludge composting facility and some estimates for a 50-dry-ton-per-day plant in Reference 13. By analyzing this data, reasonable estimates could be made for a 25 and 100 ton/day facility.

Capital costs for sludge composting include site development, equipment and 1and. A land price of $\$ 10,000 /$ acre was assumed. Part of the site development costs consisted of an 8-in. sewer line to handle runoff from the facility. However, the cost of treating the runoff is not included.

Operation and maintenance costs assume that the plant operates $8 \mathrm{hr} /$ day, 7 days/week. Over $50 \%$ of the operating costs are spent on labor, making composting a labor intensive operation. The cost analysis assumes that a payroll of five people ( 1 superintendent and 4 equipment operators) is sufficient for the 10-dry-ton-per-day facility. It was also assumed that each person would take 5 weeks off for paid sick leave, vacations, and holidays, and that 0.3 man-years of overtime would be necessary. The superintendent receives $\$ 7.50 / \mathrm{hr}$ and the operators receive $\$ 6 / \mathrm{hr}$. Labor costs include $\$ 400 /$ man for health insurance and $6 \%$ for the employer's Federal Insurance Contribution Act share.

Power requirements are based on experience from the Beltsville plant. One dry ton was assumed to require $17.3 \mathrm{kWh}$ of electricity.

The materials and supplies cost includes woodchips for a bulking agent, plastic pipe, equipment maintenance, pad and road maintenance, water, sewer, gasoline, diesel, and miscellaneous supplies. The following input quantities were assumed in this cost estimate.

$\begin{array}{ll}\text { Woodchips } & 2.75 \mathrm{yd}^{3} / \mathrm{dry} \text { ton } \\ \text { Plastic Pipe } & 12.3 \mathrm{ft} / \mathrm{dry} \text { ton } \\ \text { Gasoline } & 1.1 \mathrm{gal} / \mathrm{dry} \text { ton } \\ \text { Diesel } & 3.5 \mathrm{gal} / \mathrm{dry} \text { ton } \\ \text { Initial Solids Content of Sludge } & 23 \%\end{array}$




\section{Sludge Lagoons}

Sludge lagoon costs are taken from Reference 14. Capital costs for sludge lagoons include normal excavation, dike construction and sludge distribution piping. Labor requirements are based on, but do not include, sludge removal by contract. They include maintenance of the area and roads around the lagoons, earthwork enclosing the lagoon cells, and maintaining pumps and lines used to discharge supernatant. The principal material and supplies expenditures involve the cost of sludge removal by contract, power, surfacing used on roads in the lagoon area, and chemicals for odor and weed control.

Irradiating Wet Sludge

Costs for radiation treatment of liquid sludge are based on a preliminary engineering design of a 20,000 gal/day (gpd) pilot plant. The design was done by Molzen-Corbin and Associates of Albuquerque, New Mexico for the city of Albuquerque. The design was modified to allow costing of radiation facilities handling $100,000,300,000,500,000$, and $750,000 \mathrm{gpd}$. The validity of costs for these flows is directly related to the soundness of the original design conditions which were assumed to be accurate.

Figure B-1 shows a schematic of the radiation treatment system for wet sludge. The major component of the system is the radiation facility and source-handling pool. This consists of an insulated concrete or masonry building with a $25 \mathrm{ft}$ ceiling height. The building is sized to cover the pool and house the pumping, deionization and control equipment. Irradiating capsules are located in the pool. The capsules are $10 \mathrm{ft}$ long and $3 \mathrm{ft}$ in diameter. They contain 4 in. diameter stainless steel pipe and an array of Cesium-137 pins. Figure B-2 shows a plan view of an irradiating capsule. The $4 \mathrm{in}$. pipe is connected into a single line which circulates the sludge through the pin array. When all pins are in place each irradiating capsule has a radioactivity of $4,320,000$ curies. 


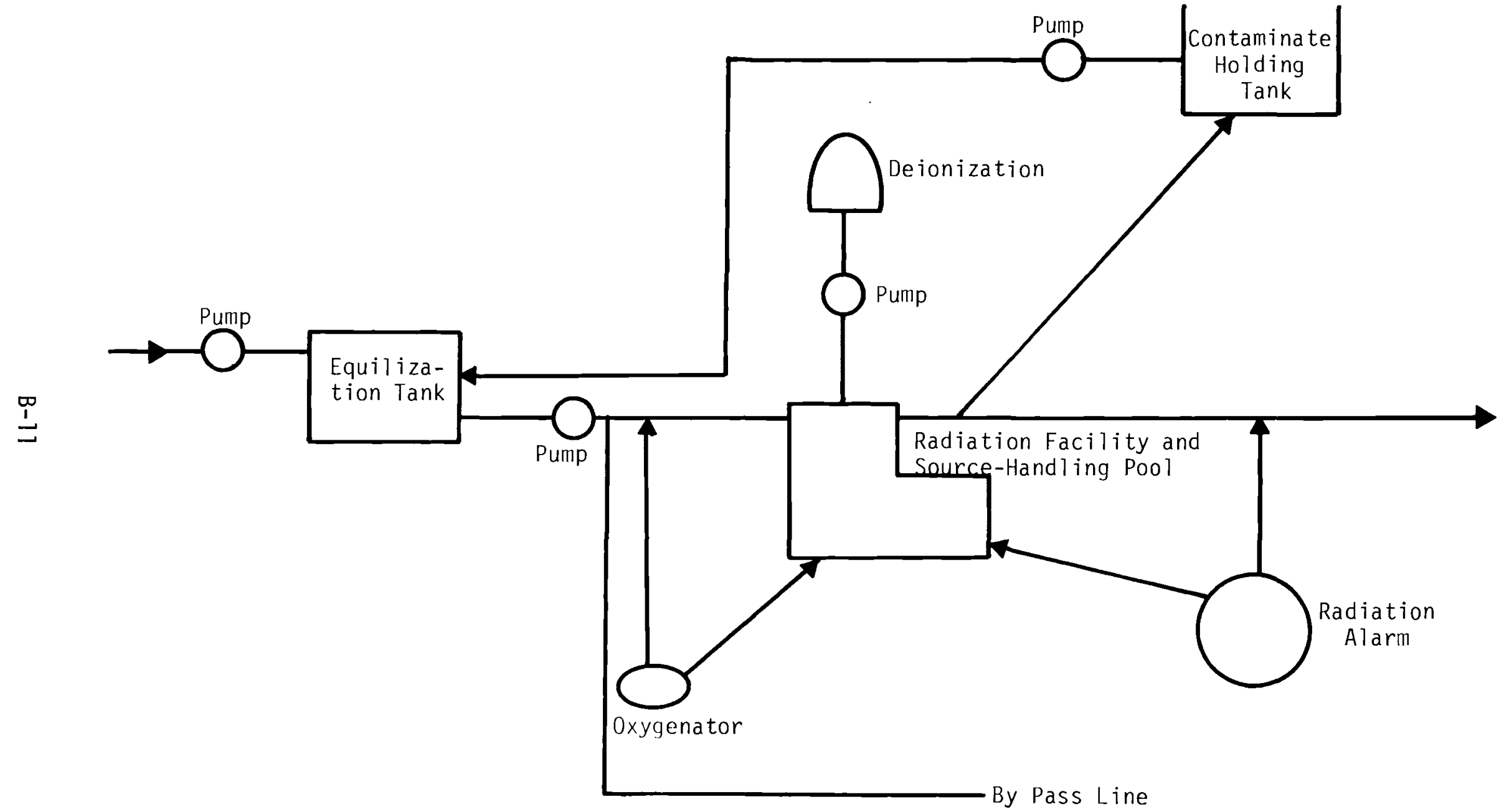

FIGURE B-1. Wet Sludge Irradiating Facility 


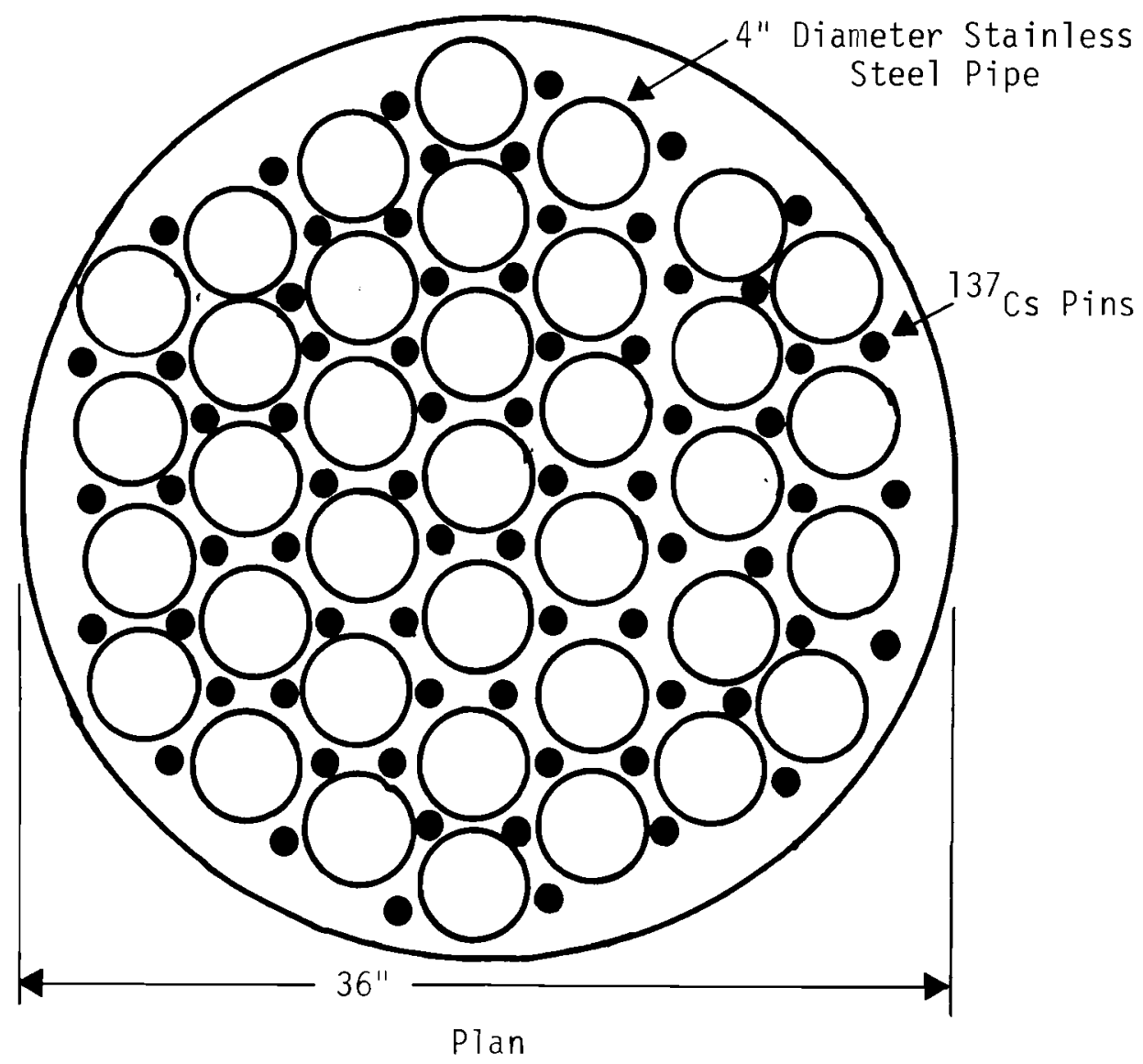

FIGURE B-2. Plan View of an Irradiating Capsule

The capital costs for wet sludge irradiation include the building, shielding, equalization tank, emergency dump tank, irradiating capsule, source-handling pool, deionizer, data acquisition and control system, oxygen injection facility, pumps, piping, radiation alarm, and fire suppression sys tem.

Labor requirements include $1.26 \mathrm{hr} /$ day for routine maintenance and cleanup, $2 \mathrm{hr} /$ day for lab work, and 3 days/month for examinations by a health physicist. Additional time is alloted for equalization and pump maintenance based on data from Reference 15 .

Power requirements are based on the energy used for lighting, ventilation, equalization, pumping, and monitoring the radiation process. Maintenance material and supply costs take into account recharge of the deionization beds, 
purchase of oxygen, and materials necessary for pump and equalization maintenance. An allowance is taken to include the rental of a crane once every 5 years. The crane will be used to place a cask into the source-handling pool when additional Cesium-137 must be added.

The source costs were developed by Sandia Laboratories. These costs have been computed in a fairly complex manner. The useful life of Cesium-137 is assumed to be 60 years, so that with a half-life of 30 years, $25 \%$ of the source is eventually recycled into the source preparation and disposal system. The cost of the recycled portion of the source is borne by the three source users (20-yr plant life) in proportion to the amount of source material that each user depletes. The initial charge is amorized as capital equipment and the recharges every 5 years are regarded as expense. Transportation, loading, and unloading costs are included, and at the end of the plant life, a salvage rate of $\$ 0.10 / \mathrm{C} i$ is assumed unless the $\gamma$-source is over 60 years old.

\section{Irradiating Dry Sludge}

Dry irradiation costs are based on experience from a pilot plant currently under construction at Sandia Laboratories in Albuquerque, New Mexico. Sandia has provided preliminary design specifications and costs covering the bulk of the dry sludge irradiation cost data developed for this report.

The radiation treatment facility design centers around a bucket conveyor which carries the dry sludge. Figure B-3 shows a side view of Sandia's pilot plant operation. For plants handling 25 tons/day or more, the design was altered to that shown in Figure B-4. The costs allow for construction of a pre-engineered steel building at the loading/unloading location. The bucket conveyor empties the irradiated sludge onto a belt conveyor which transports the material to a storage bin within the building. The bin is sized to allow a 2-day storage volume. A backhoe is used to empty a full bin. It was assumed that treatment plants would have a backbone available. No allowance was made for purchase or maintenance of the backhoe. Also located inside the building is a small control room where an operator can monitor the entire radiation treatment process. 


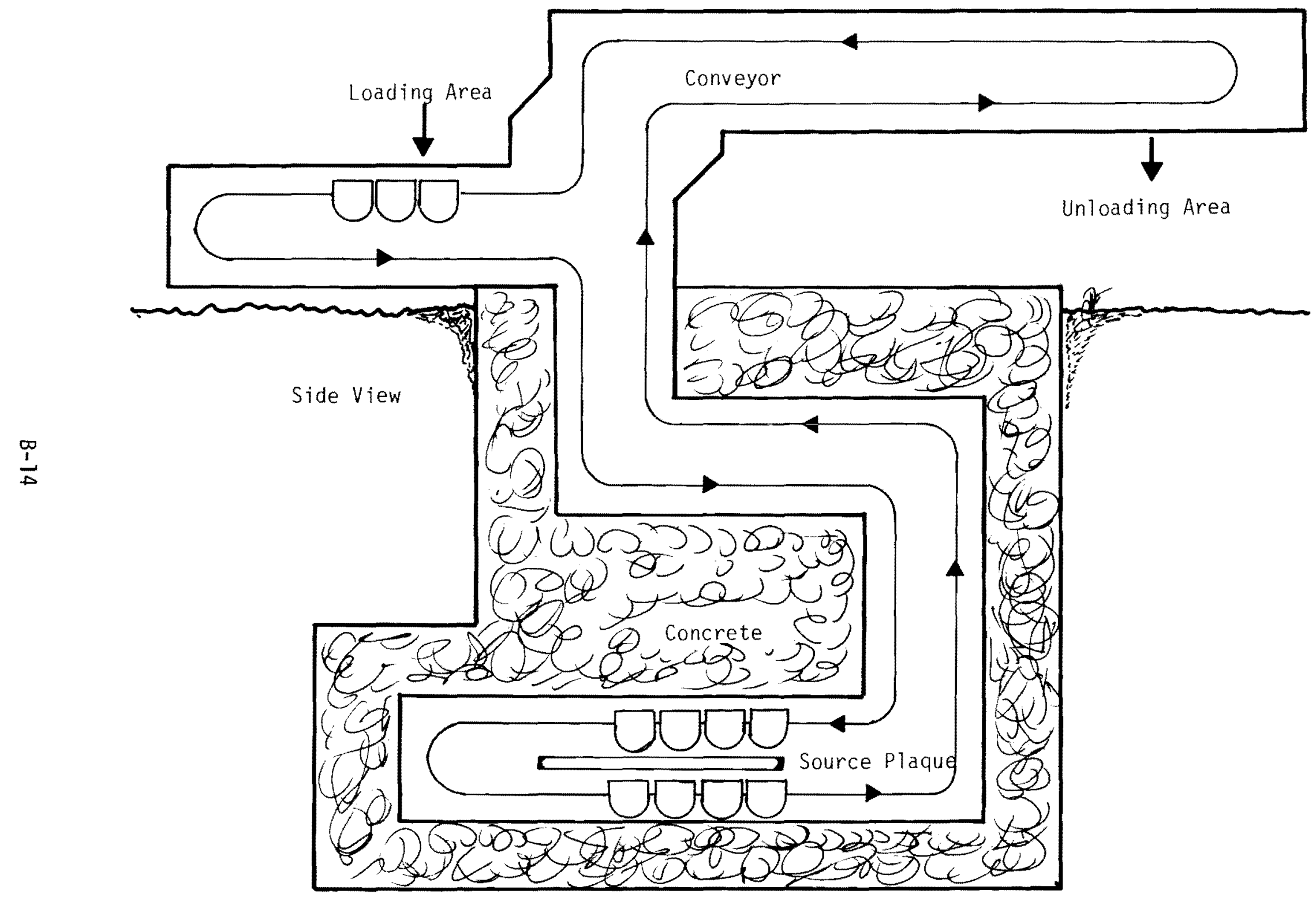

FIGURE B-3. Sandia Sludge Irradiation Facility 


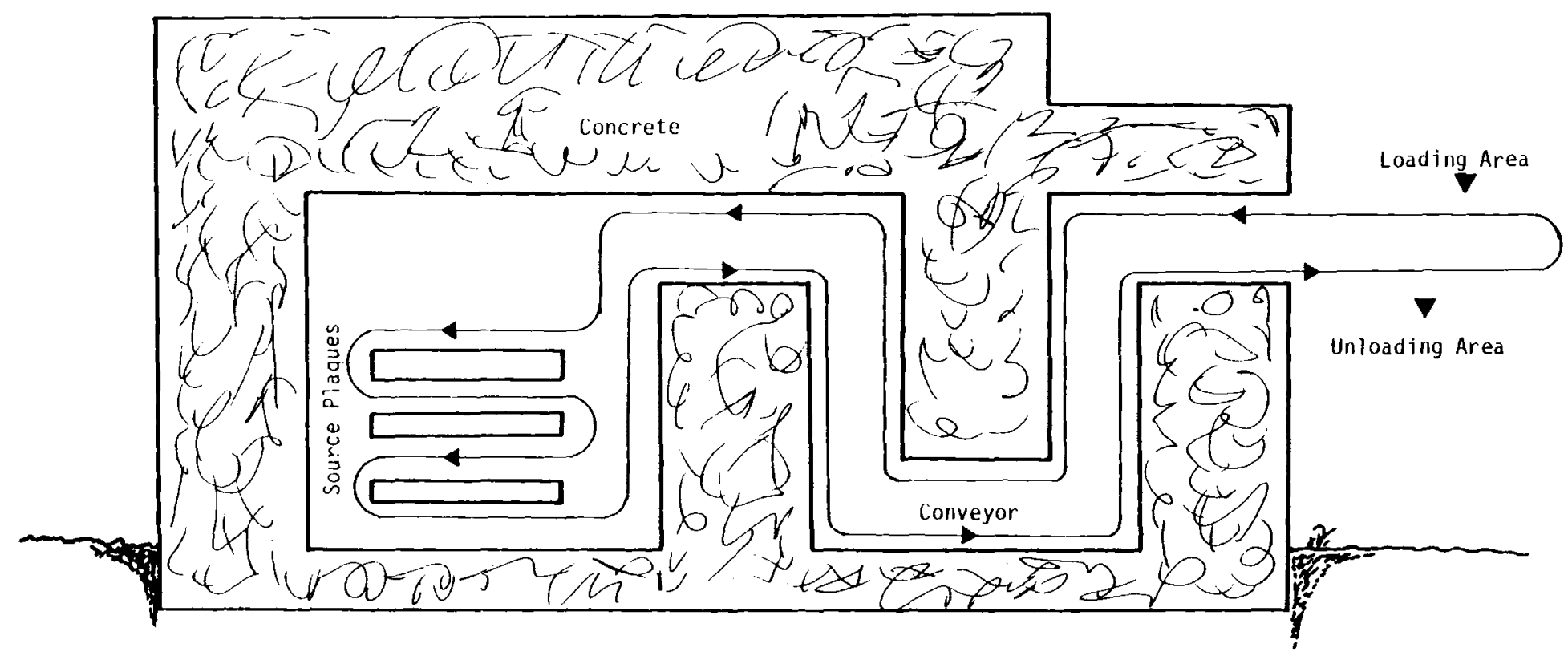

FIGURE B-4. Radiation Treatment Facility for Handling 25 TPD or More of Dry Sludge 
The bucket conveyor loading mechanism includes a storage hopper (holding an 8-hr volume of sludge) and a loading hopper. A screw conveyor connects the two units. The loading hopper automatically empties a measured volume of sludge into the buckets.

The dry sludge irradiation plant design also includes a source-handling pool. The source plaques are slid on a track into the pool. The pool is filled with $25 \mathrm{ft}$ of water and the cover is removed. After the source is placed into the plaque, the pool is drained and the plaque slid mechanically back into place. A lead shutter covers the opening between the pool and plaque.

When the pool is drained, the water is first pumped into a small tank and tested for contamination. If clean, it is pumped onto the ground or into a drainage area. If contaminated, a unit is brought from offsite to process the water before the pool is pumped dry.

Capital costs for the dry sludge irradiation plant include basic site preparation, concrete work, grouting, stainless steel tank materials, steel reflector plates, access ladders, pumps, ventilator, filters, hoists, lead shield door, source plaque and drives, fire suppression system, radiation alarm system, conveyor assembly, storage hopper, loading hopper, steel building covering the loading and dumping locations along the conveyor, pool water testing tank, and miscellaneous mechanical and electrical work.

Labor requirements account for loading the storage hopper once per $8 \mathrm{hr}$ shift for every 25 tons of dry solids processes. An allowance of $10 \mathrm{hr} / \mathrm{yr}$ is assumed for filter maintenance, $8 \mathrm{hr} / \mathrm{yr}$ for swab tests, $30 \mathrm{~min} / \mathrm{badge/}$ quarter for dosimeter processing, $1 \mathrm{hr} /$ month for a routine site survey, $8 \mathrm{hr} / \mathrm{yr}$ for a radiation sensor check and $1.26 \mathrm{hr} /$ day for general maintenance and cleanup.

Power requirements are based on the ratings for the belt drive motor, air blower and radiation alarms. Other building power requirements such as lighting, heating and ventilation were also included. 
Maintenance materials and supplies costs include the purchase of replacement filters, molydisulfide ( $2 \mathrm{lb} /$ month/25 tons of dry solids processed) and other miscellaneous materials.

Source costs are based on the same assumptions as outlined in the previous section.

Thermoradiation

Thermoradiation costs are based on the same parameters as wet sludge irradiation except an allowance is taken in all cases for a boiler and steam injection system capable of maintaining the sludge temperature at $55^{\circ} \mathrm{C}$. This allows for application of a smaller radiation dose and a general reduction in the capital outlay. A schematic of the thermoradiation facility is shown in Figure B-5.

Boiler labor requirements were included in accordance to data contained in Reference 16. The increase in power demand was accounted for by applying manufacturer supplied data. Fuel requirements were also computed based on manufacturer data. The maintenance material and supplied cost for a boiler was assumed to be $3 \%$ of the capital cost.

\section{Pasteurization}

The sludge pasteurization costs presented in this report were developed by Culp/Wesner/Culp, for Battelle, Pacific Northwest Laboratories. A schematic of the pasteurization system is presented in Figure B-6. The following assumptions apply to the development of the costs for this system.

1. Specific heat of sludge $=1.0 \mathrm{Btu} / 1 \mathrm{~b} /{ }^{\circ} \mathrm{F}$

2. Feed sludge temperature

$$
\text { Raw }-17^{\circ} \mathrm{C}
$$$$
\text { Digested }-27^{\circ} \mathrm{C}
$$

3. Sludge pumping done with positive displacement pumps

4. Boiler assumed to supply medium pressure (100 to $125 \mathrm{psi}$ ) steam with a heat output of $970 \mathrm{Btu} / 1 \mathrm{~b}$. Boiler efficiency is $80 \%$. 


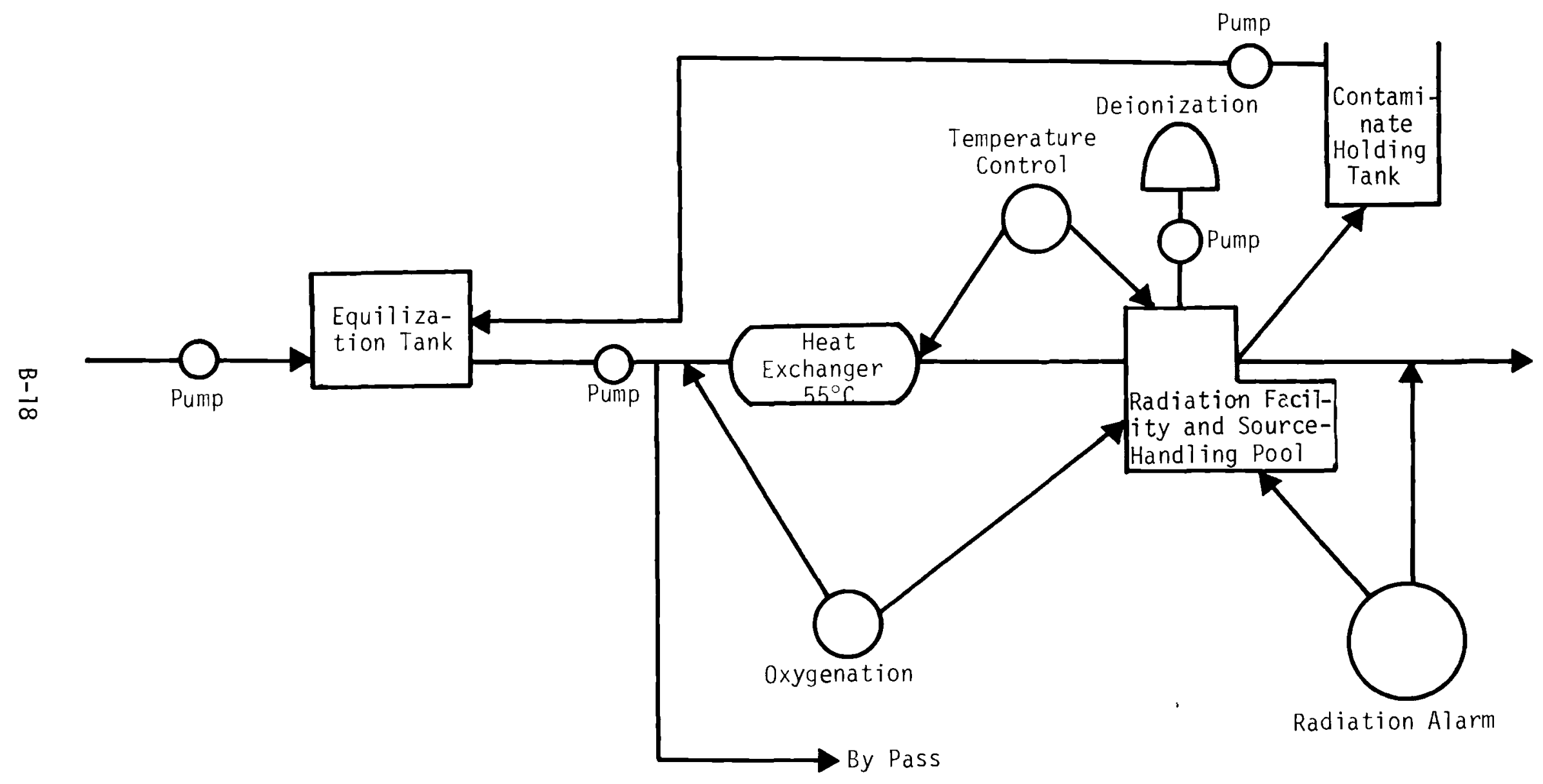

FIGURE B-5. Thermoradiation Facility 
$\frac{1}{6}$

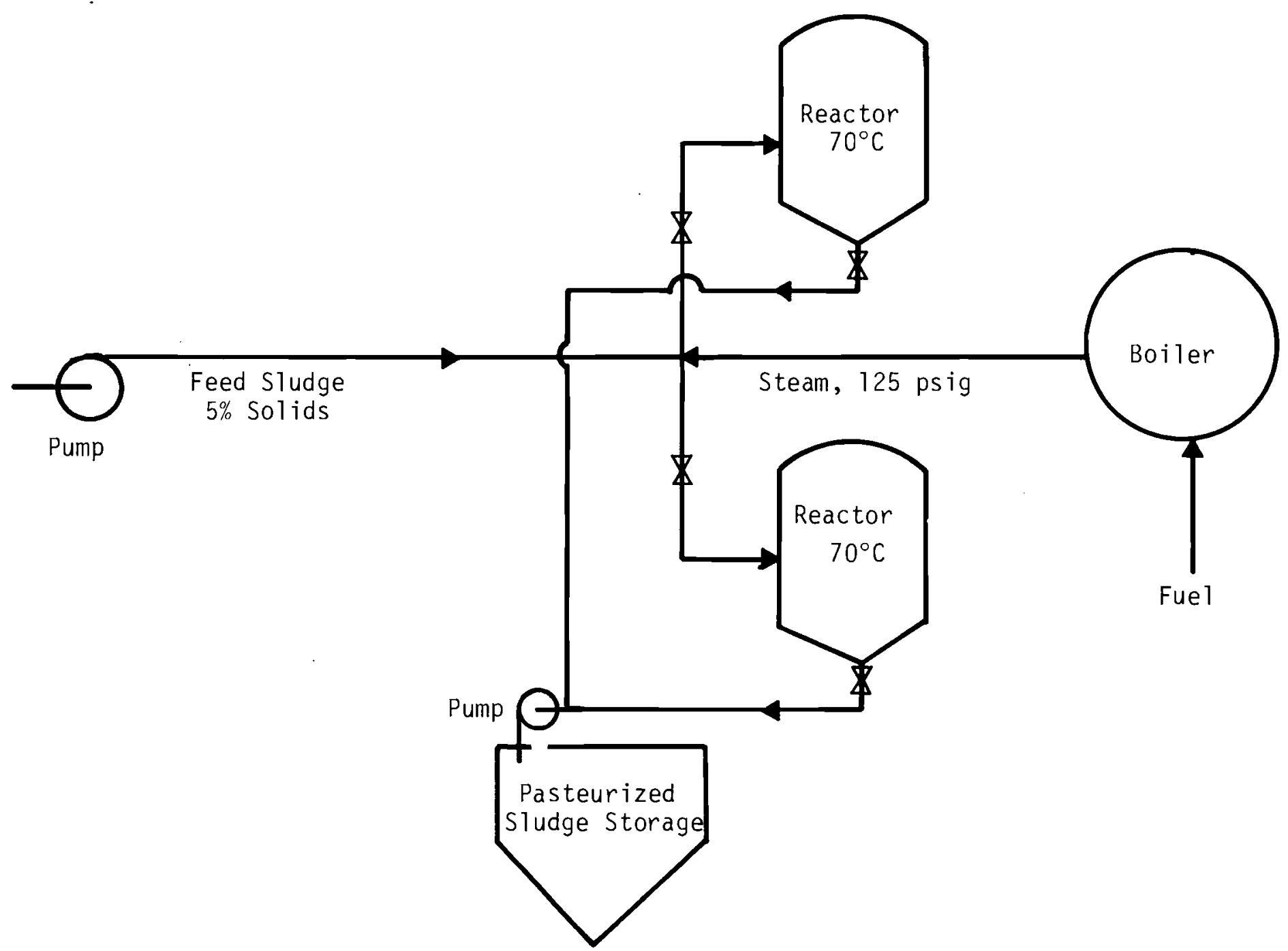

FIGURE B-6. Sludge Pasteurization System 
5. Four days storage capacity provided for pasteurized sludge.

6. Ten percent heat loss in system. A11 piping and the reactor are insulated to minimize heat loss.

7. No heat recovery.

The operating schedule assumed for sizing the pasteurization system is shown in Table B-6.

TABLE B-6. Pasteurization Plant Operating Schedule

Plant

Capacity

\begin{tabular}{|c|c|c|c|c|c|c|}
\hline (mgd) & $\mathrm{hr} /$ day & day/wk & $\mathrm{gpm}$ & $\mathrm{hr} /$ day & day/wk & gpm \\
\hline 5 & 6 & 4 & 100 & 4 & 5 & 100 \\
\hline 10 & 8 & 5 & 140 & 8 & 5 & 100 \\
\hline 25 & 16 & 5 & 175 & 16 & 5 & 115 \\
\hline 50 & 24 & 5 & 235 & 24 & 5 & 155 \\
\hline 75 & 24 & 7 & 250 & 24 & 7 & 165 \\
\hline 100 & 24 & 7 & 335 & 24 & 7 & 220 \\
\hline
\end{tabular}

Capital costs include materials, installation labor, equipment, electrical work, normal excavation, and contractor overhead and profit. Labor requirements include one full-time operator for the hours the system is in operation. One-quarter time of system operation is assumed for maintenance.

Power requirements are based on the pump sizes. Fuel requirements were calculated from boiler design data. Maintenance material and supplies costs are based on the cost of materials for pumping and on $5 \%$ of the equipment costs for the boiler, heat exchanger and reactor.

Transporting Sludge by Truck

The costs for transporting sludge are based on References 3 and 8. The costs include fuel, truck maintenance, truck amortization (6 years at $7 \%$ ), loading and unloading facility amortization (20 years at $7 \%$ ), labor, maintenance supplies, electrical energy, overhead and supervision. It was assumed that the treatment plant personnel drove the trucks. 
A 5500 gal tanker truck was used for transporting liquid sludge and a $30 \mathrm{yd}^{3}$ dump truck for dewatered sludge. The trucks were assumed to operate $8 \mathrm{hr} /$ day, 360 days a year. They were assumed to trave 1 at $25 \mathrm{mph}$ for the first 20 miles and at $35 \mathrm{mph}$ thereafter. A 10\% allowance over truck operating time was included when calculating driver time.

The loading facilities include a dispatch office, loading equipment, and enclosure for trucks being loaded. Liquid sludge is loaded through a flexible hose and dewatered sludge by means of a hopper. The maximum loading time is 20 min. The unloading facilities include an office, enclosure for trucks being unloaded and a truck ramp. All unloading was by gravity.

For the treatment options dealing with wet and moist sludge, it was assumed necessary to transport the sludge 20 miles to a reuse or disposal area. If the sludge was sufficiently stabilized, it was incorporated in a land spreading operation. However, wet sludge receiving disinfection treatment only was assumed too objectionable to land spread, therefore it was injected into the soil. Land spreading and soil injection costs were taken from Reference 8.

No transport cost was assumed for dry sludge. Since there are existing or potential markets for all the end products produced by the dry sludge treatment options, it was assumed that the treated sludge value would be sufficient to offset any transportation costs. The removal of incinerator ash was accounted for in the calculation of material and supply costs. 


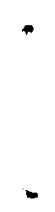

. 


\section{Process}

Anaerobic Digestion

Lime Stabilization

Storage and Feeding

Rapid Mixing

Contact Tank

Thermal Conditioning

Wet Air Oxidation

Recycled Liquor

Odor Control

Vacuum Filtration

Filter Pressing

Flash Drying

Multiple Hearth Incineration

Static Pile Composting

Sludge Lagoons

Irradiating Wet Sludge

Irradiating Dry Sludge

Thermoradiation

Pasteurization

Transporting Sludge by Truck

Disposal Costs
Capital

B-22

$B-25$

$\mathrm{B}-29$

B-33

B-37

B -42

B-46

B-48

B-51

B-55

B-58

B-63

B-67

B-70

B-75

B-80

B-85

See Pages B-90 through B-99

See Page B-100
Operation and Maintenance

$B-23, B-24$

$\mathrm{B}-26, \mathrm{~B}-27, \mathrm{~B}-28$

$B-30, B-31, B-32$

$B-34, B-35, B-36$

$B-38, B-39, B-40, B-41$

$B-43, B-44, B-45$

B -47

$B-49, B-50$

$B-52, B-53, B-54$

B-56, B-57

$B-59, B-60, B-61, B-62$

B-64, B-65, B-66

$B-68, B-69$

$B-71, B-72, B-73, B-74$

$\mathrm{B}-76, \mathrm{~B}-77, \mathrm{~B}-78, \mathrm{~B}-79$

B-74, B-81, B-82, B-83, B-84

$\mathrm{B}-86, \mathrm{~B}-87, \mathrm{~B}-88, \mathrm{~B}-89$ 


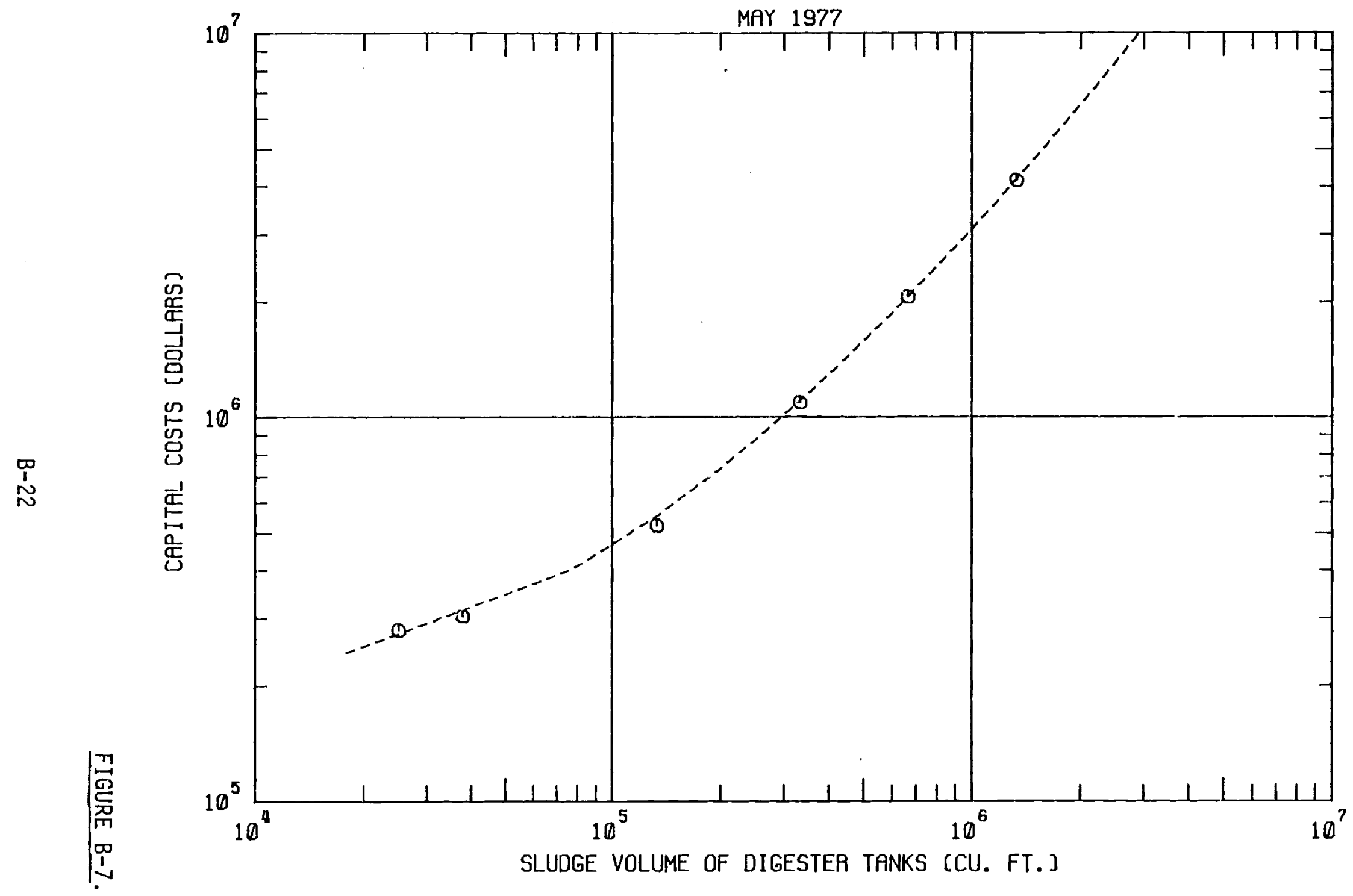

ANAEROBIC DIGESTION - CAPITAL COSTS 


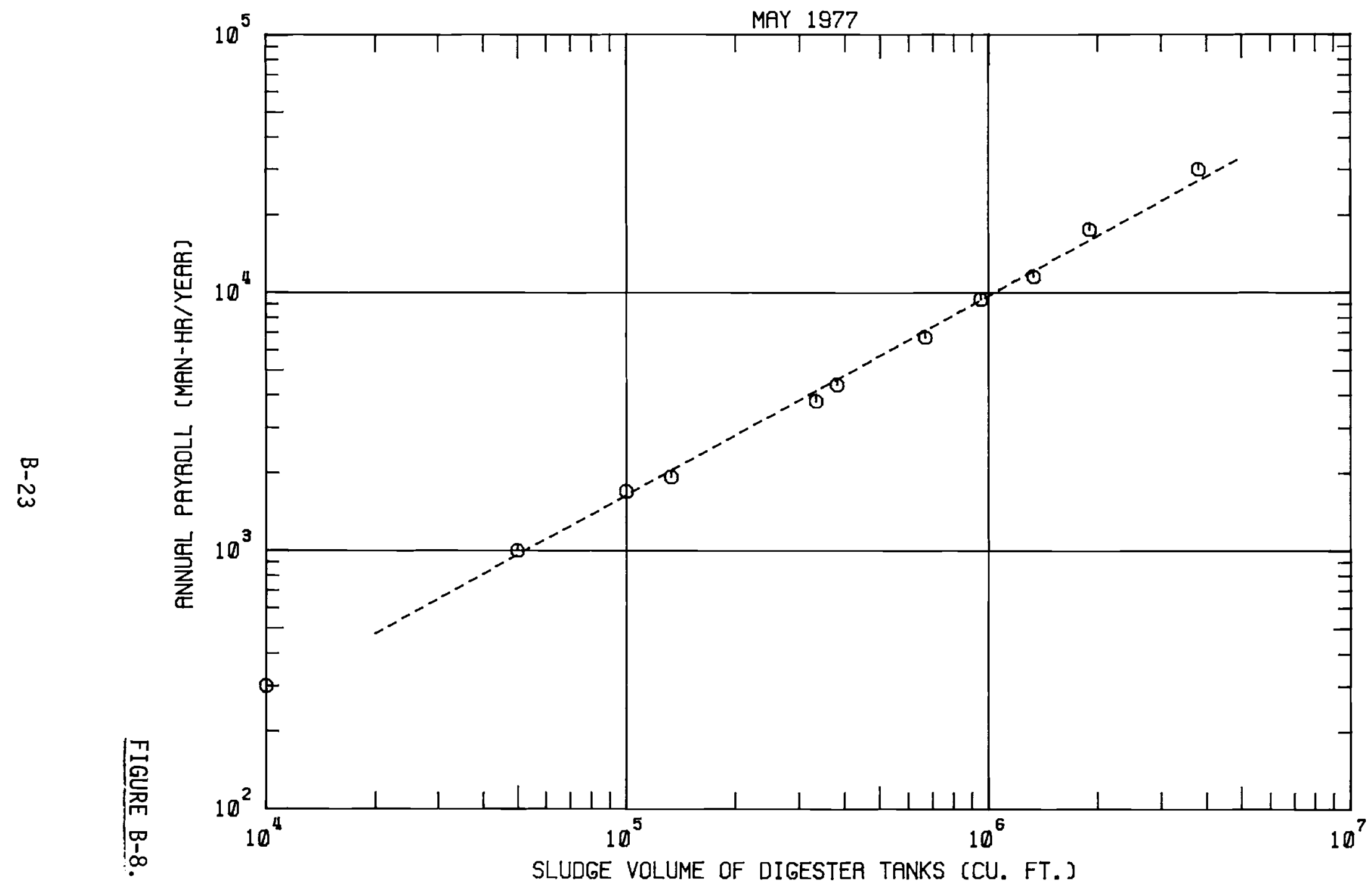

ANAEROBIC DIGESTION - LABOR REQUIREMENTS 


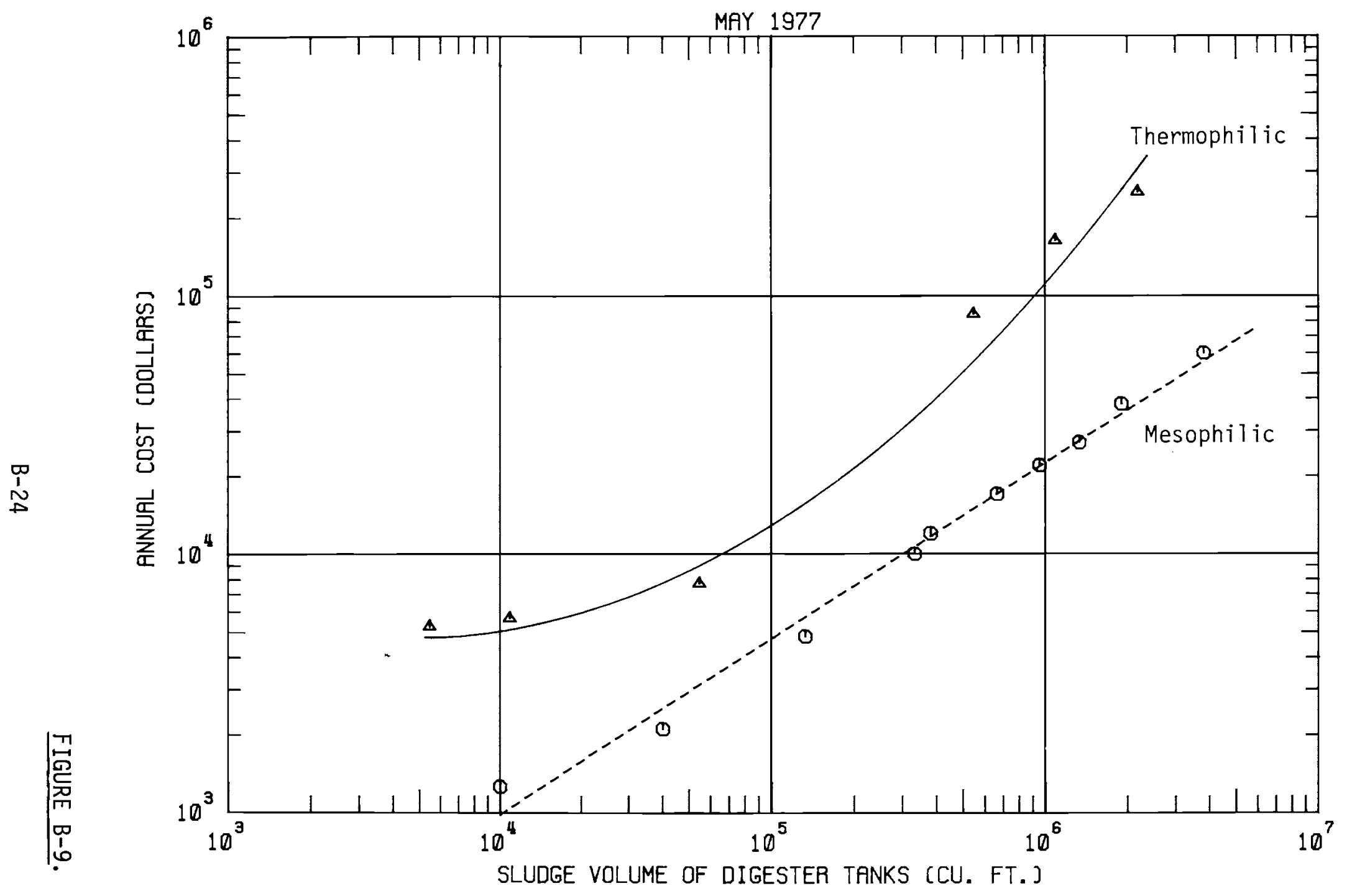

ANAEROBIC DIGESTION - MAINTENANCE

MATERIAL AND SUPPLIES COSTS 


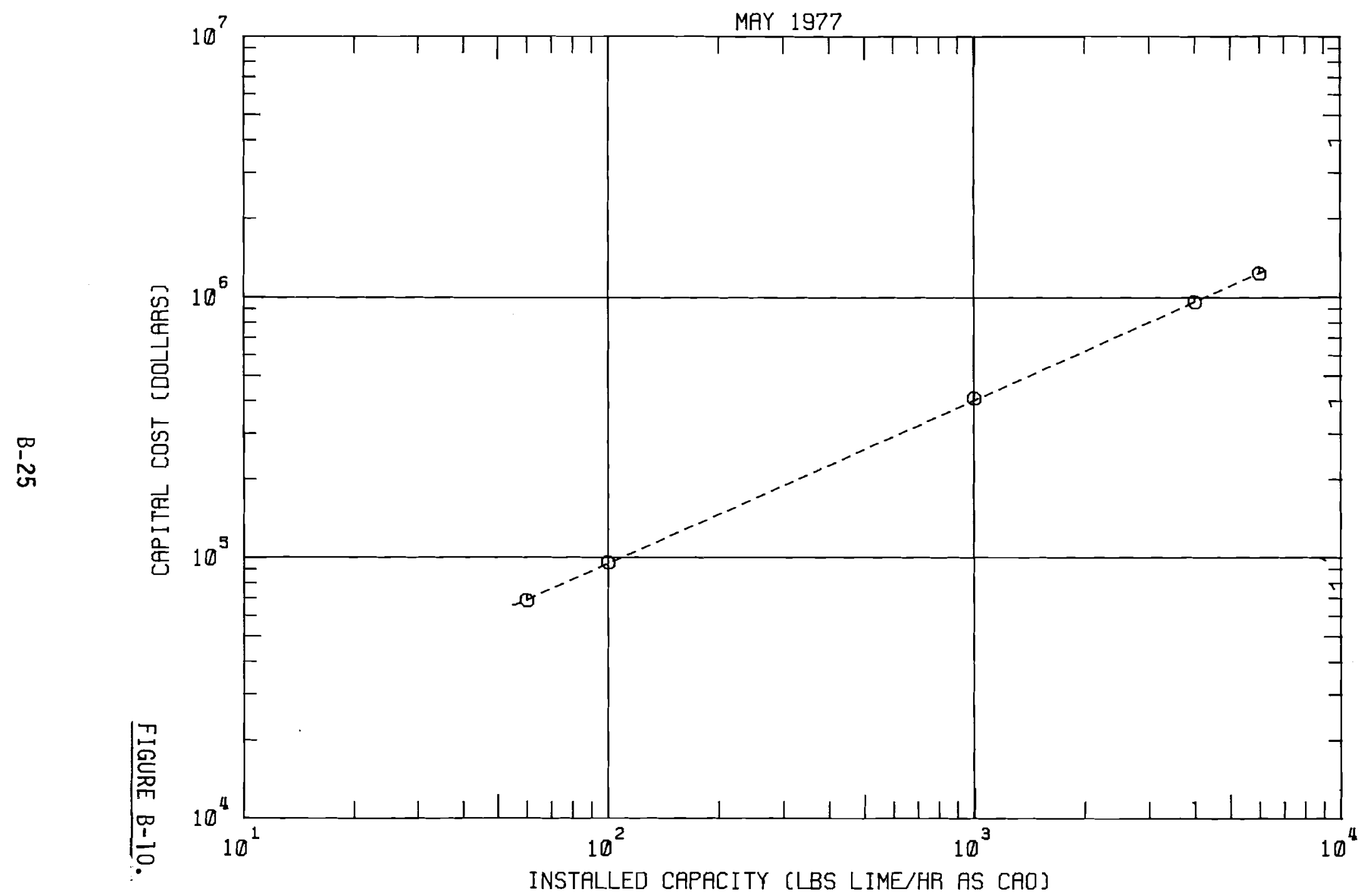

LIME STABILIZATION - STORAGE AND FEEDING CAPITAL COSTS 


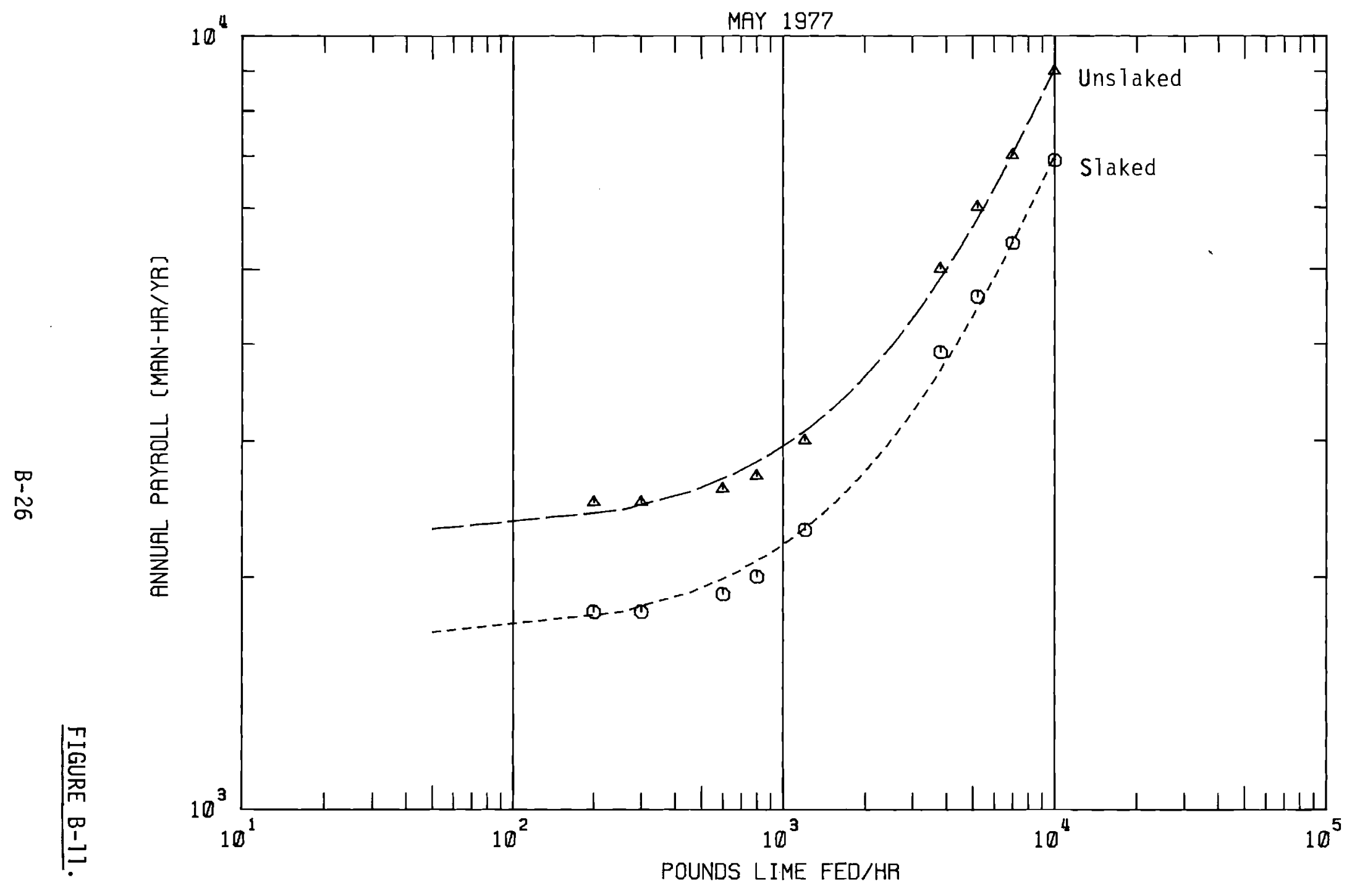

LIME STABILIZATION - STORAGE AND FEEDING LABOR REQUIREMENTS 


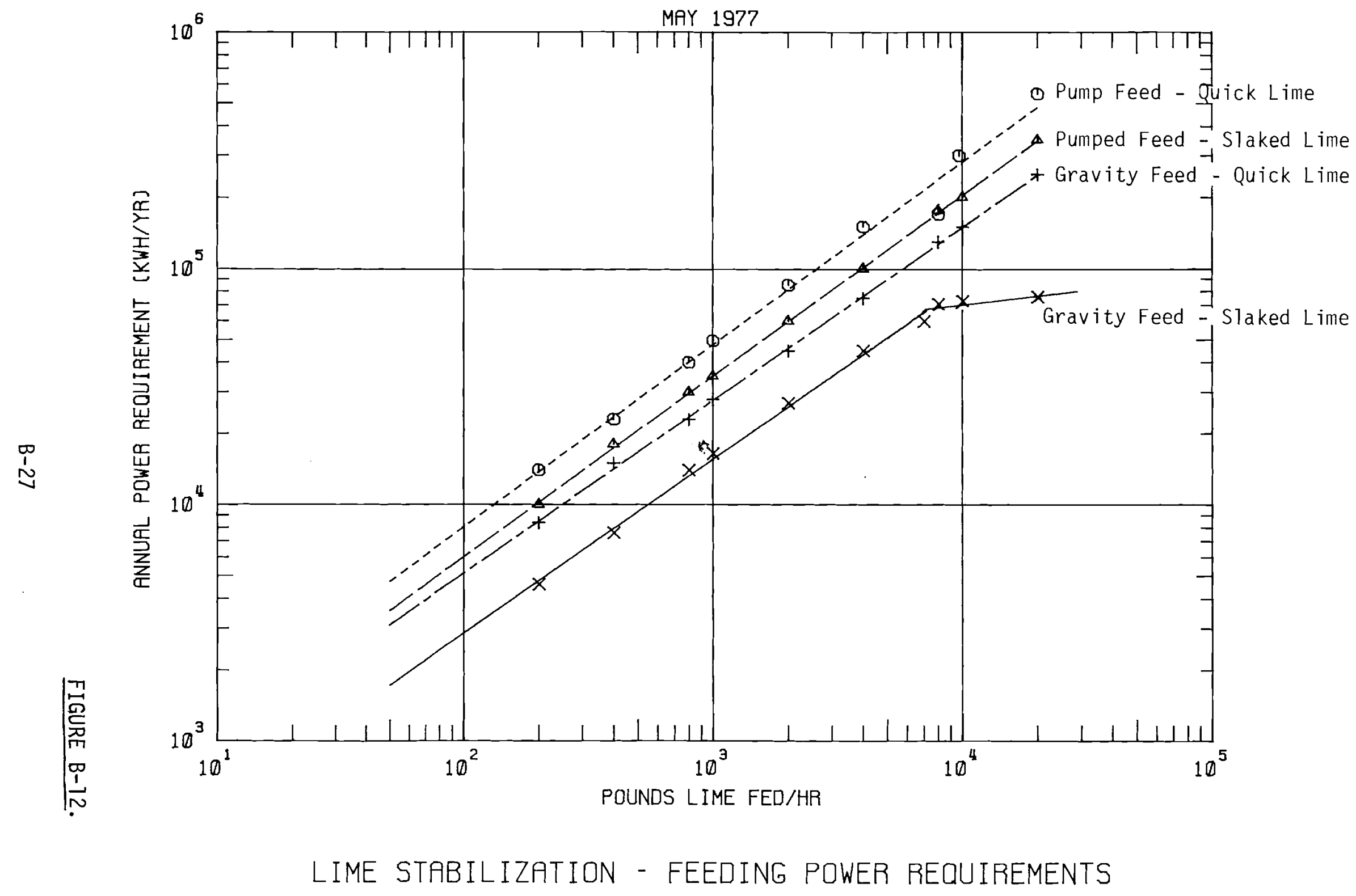




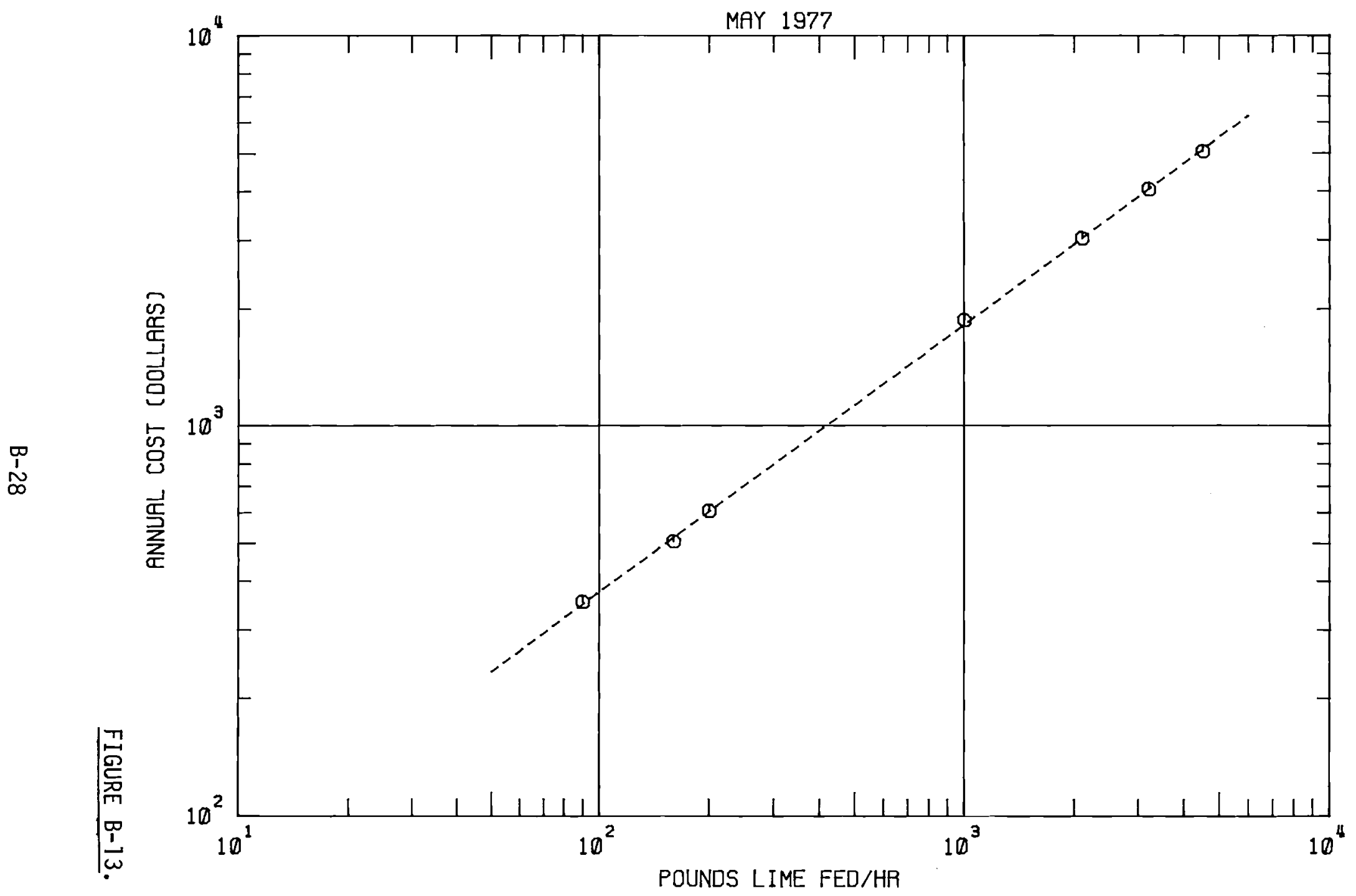

LIME STABILIZATION - STORAGE AND FEEDING MAINTENANCE MATERIAL AND SUPPLIES COSTS 


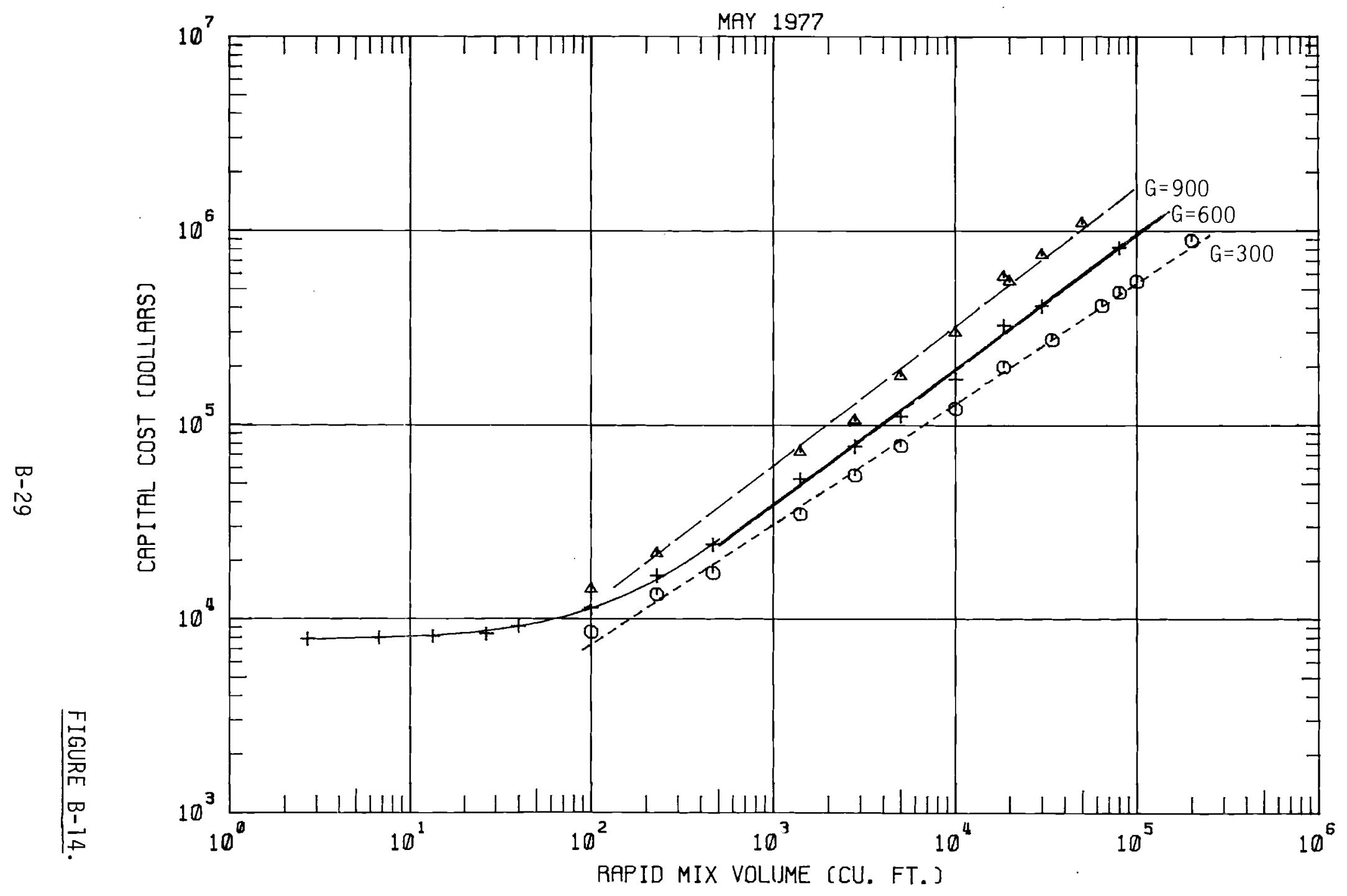

RAPID MIXING - CAPITAL COSTS 


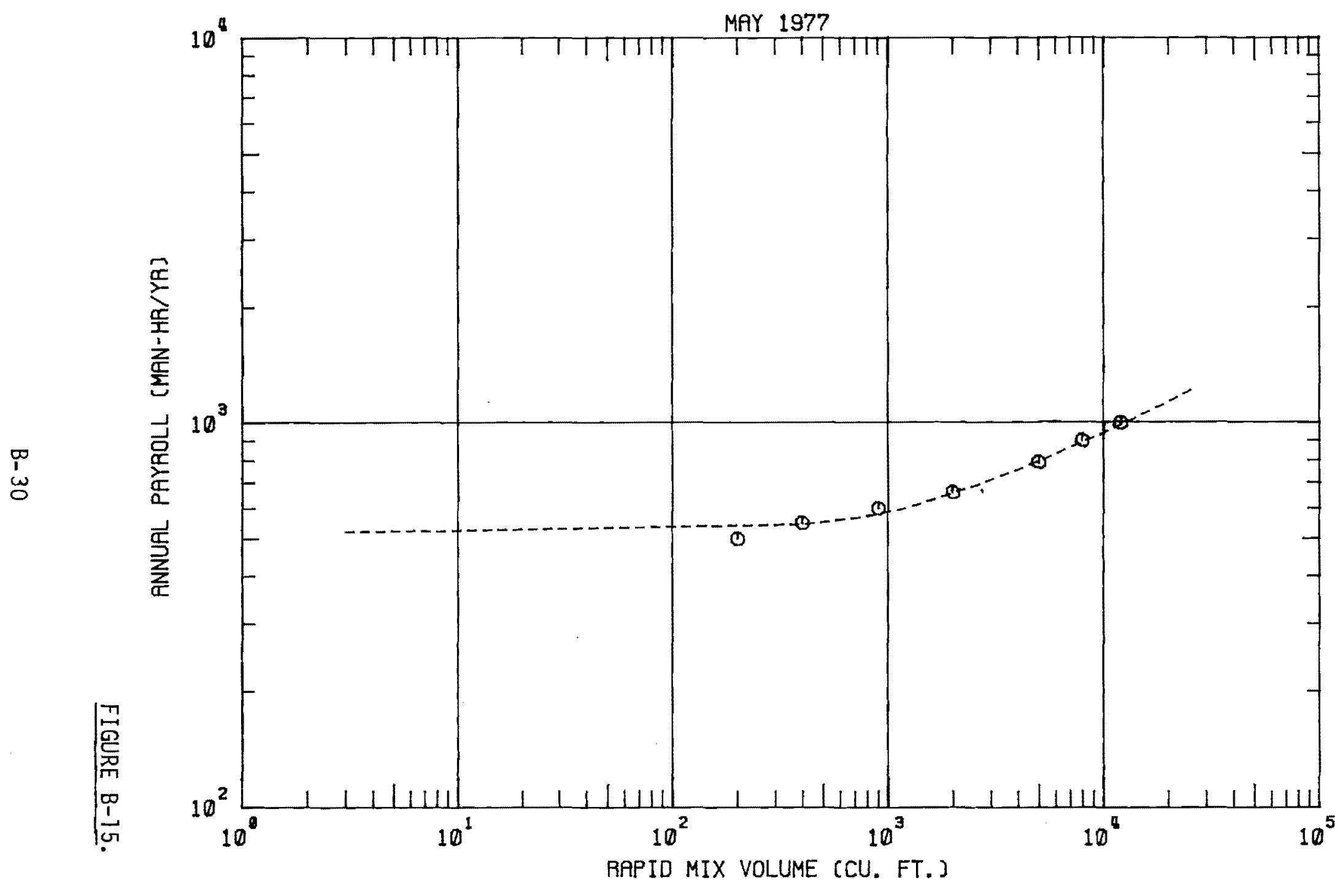

RAPID MIXING - LABOR REQUIREMENTS 


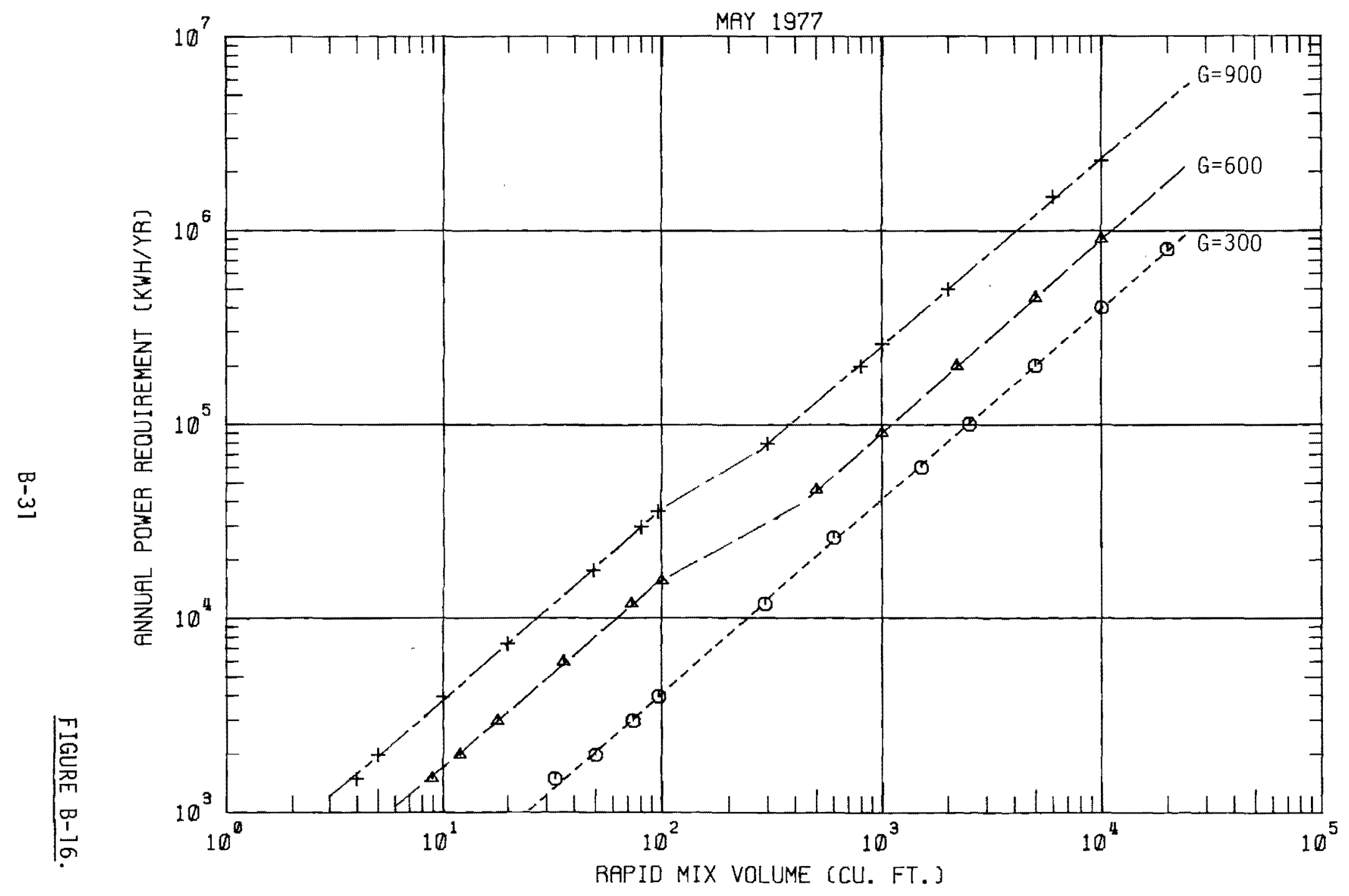

RAPID MIXING - POWER REQUIREMENTS 


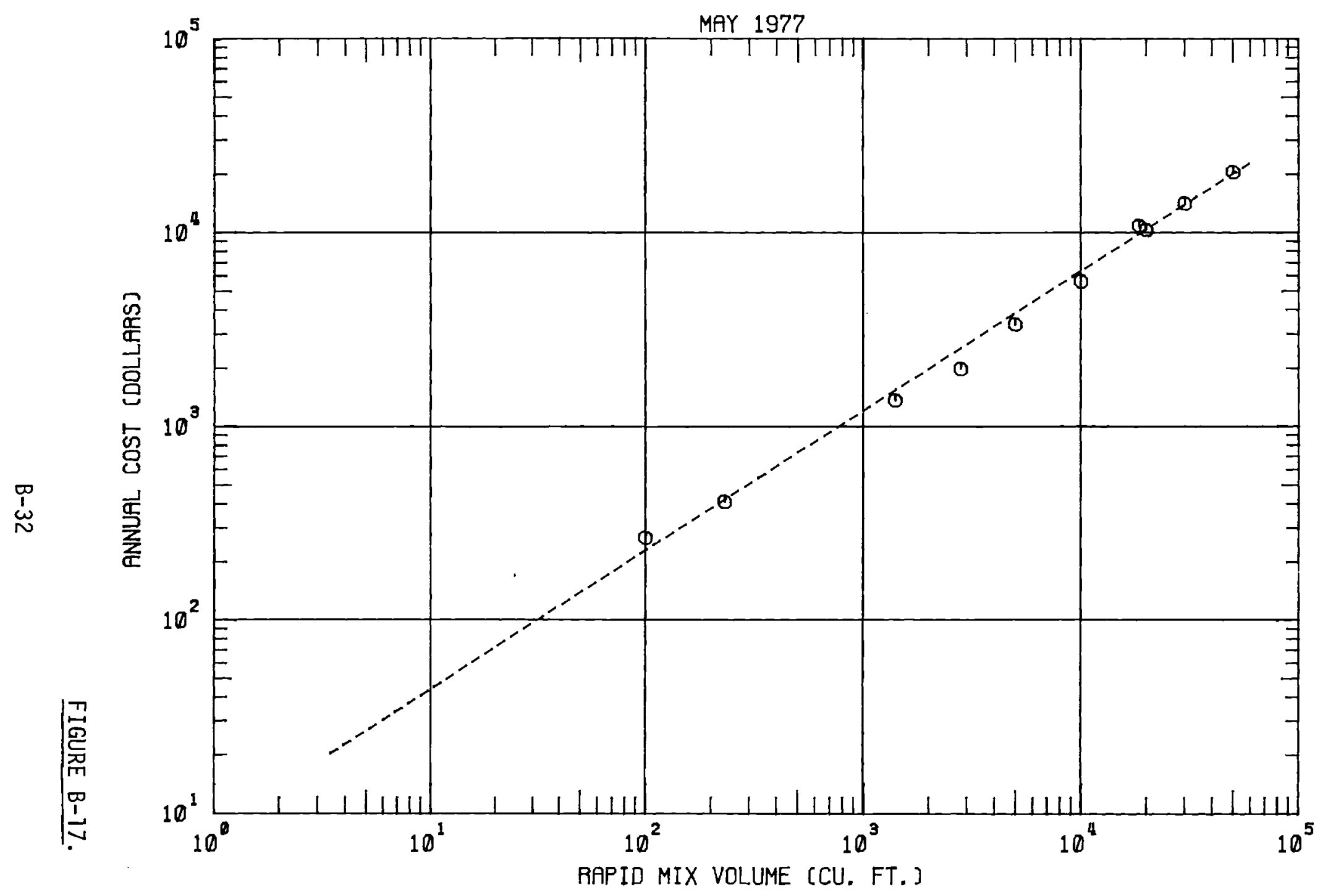

RAPID MIXING - MAINTENANCE MATERIAL AND SUPPLIES COSTS 


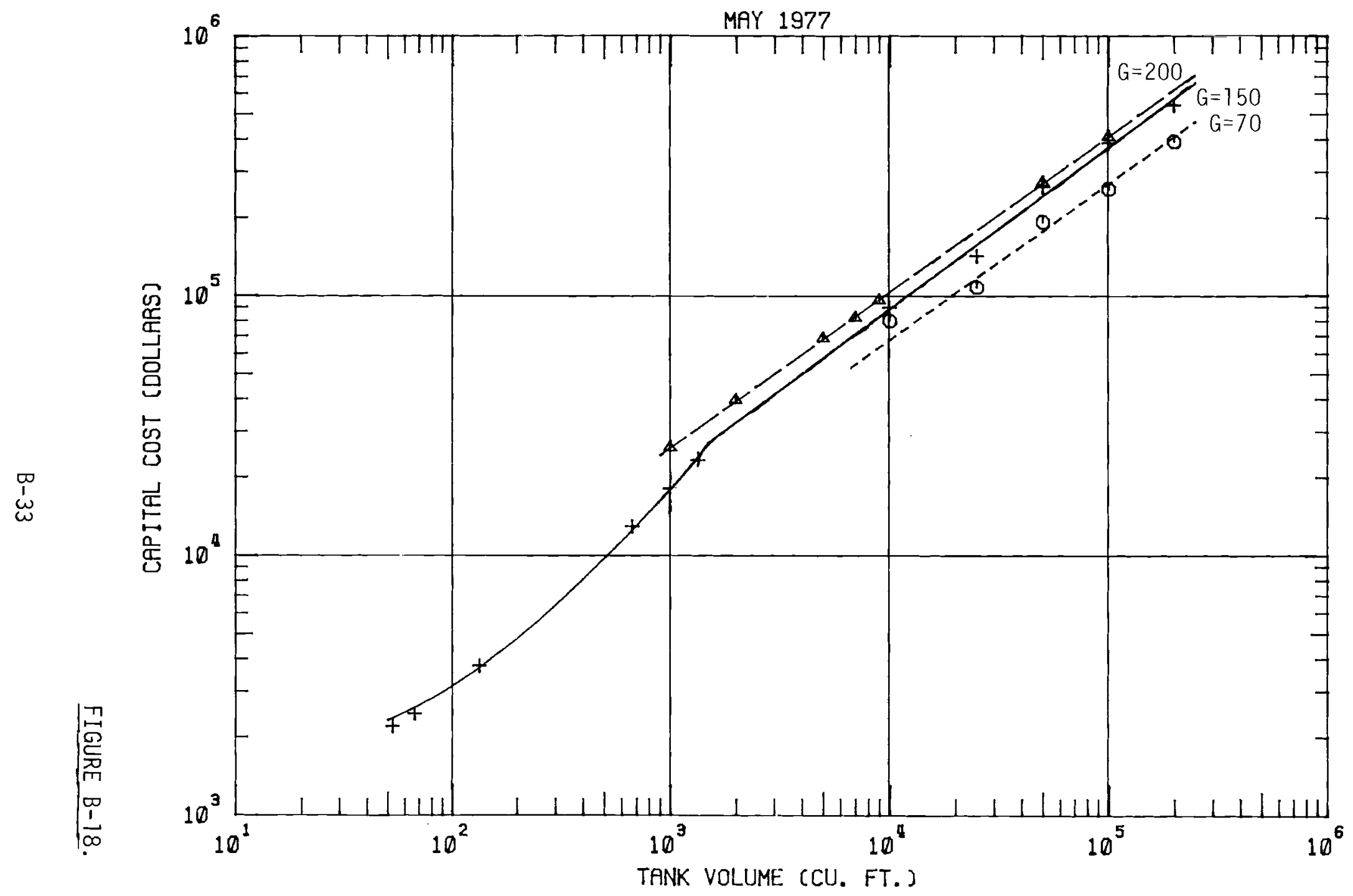

CONTACT TANK - CAPITAL COSTS 


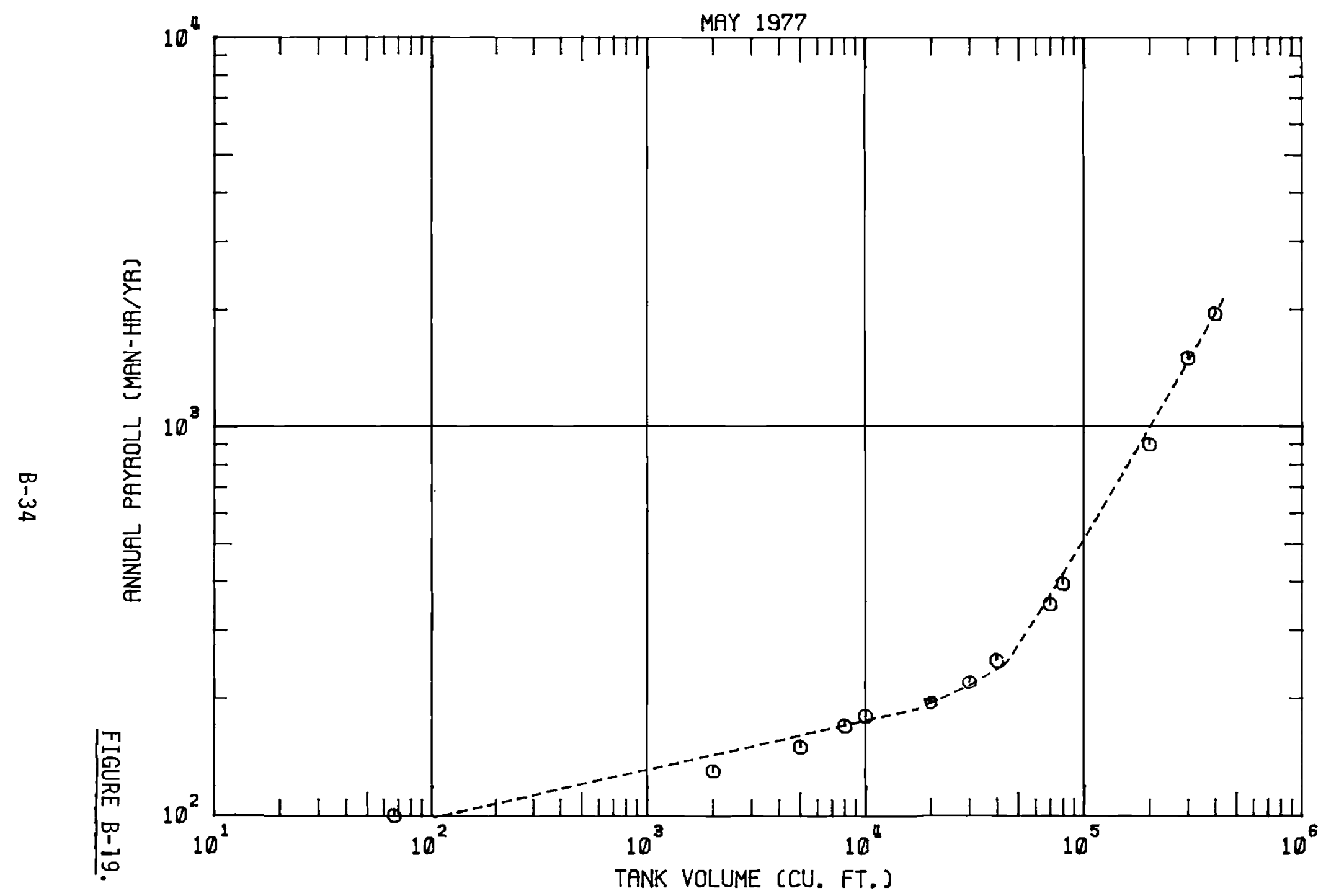

CONTACT TANK - LABOR REQUIREMENTS 


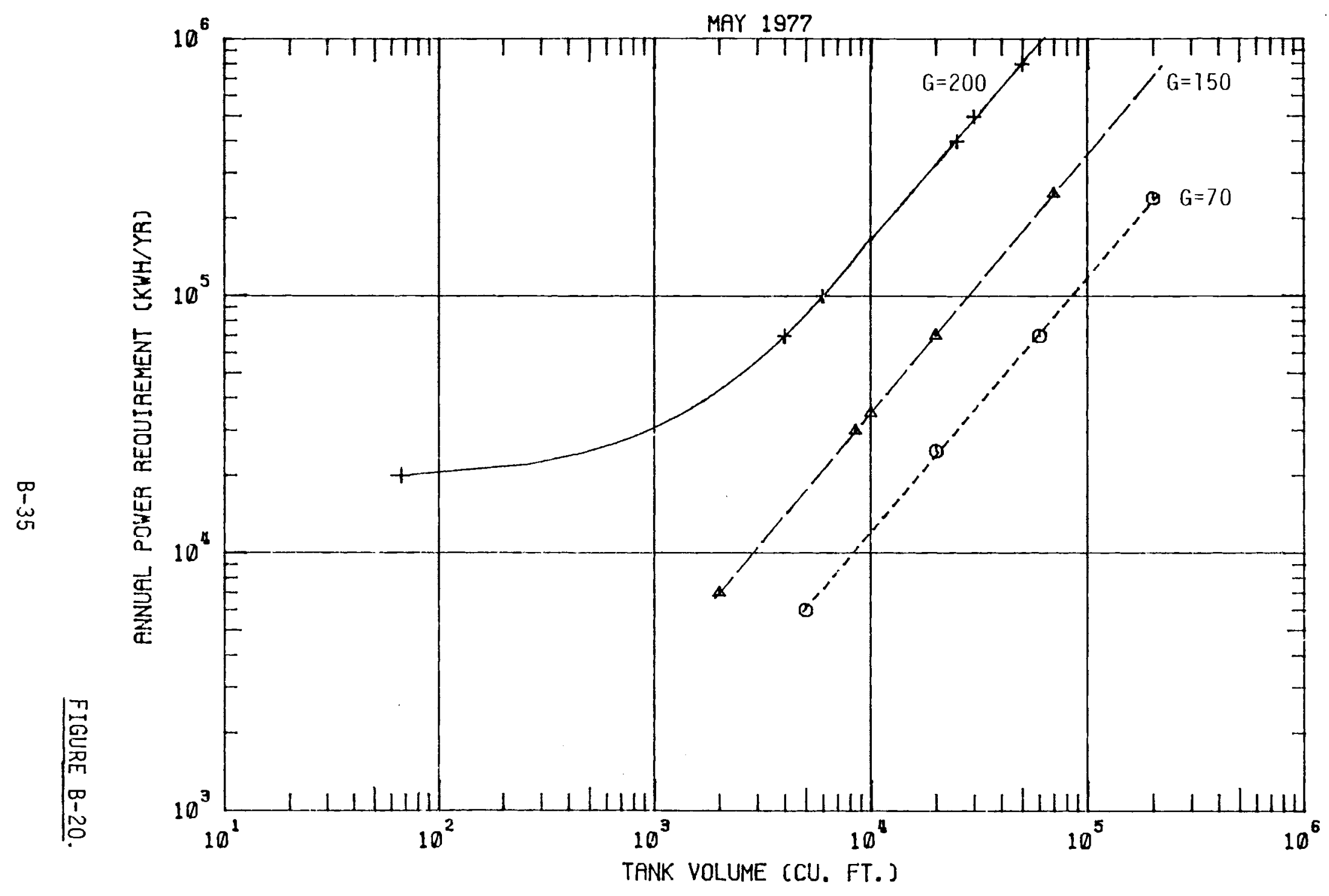

CONTACT TANK - POWER REQUIREMENTS 


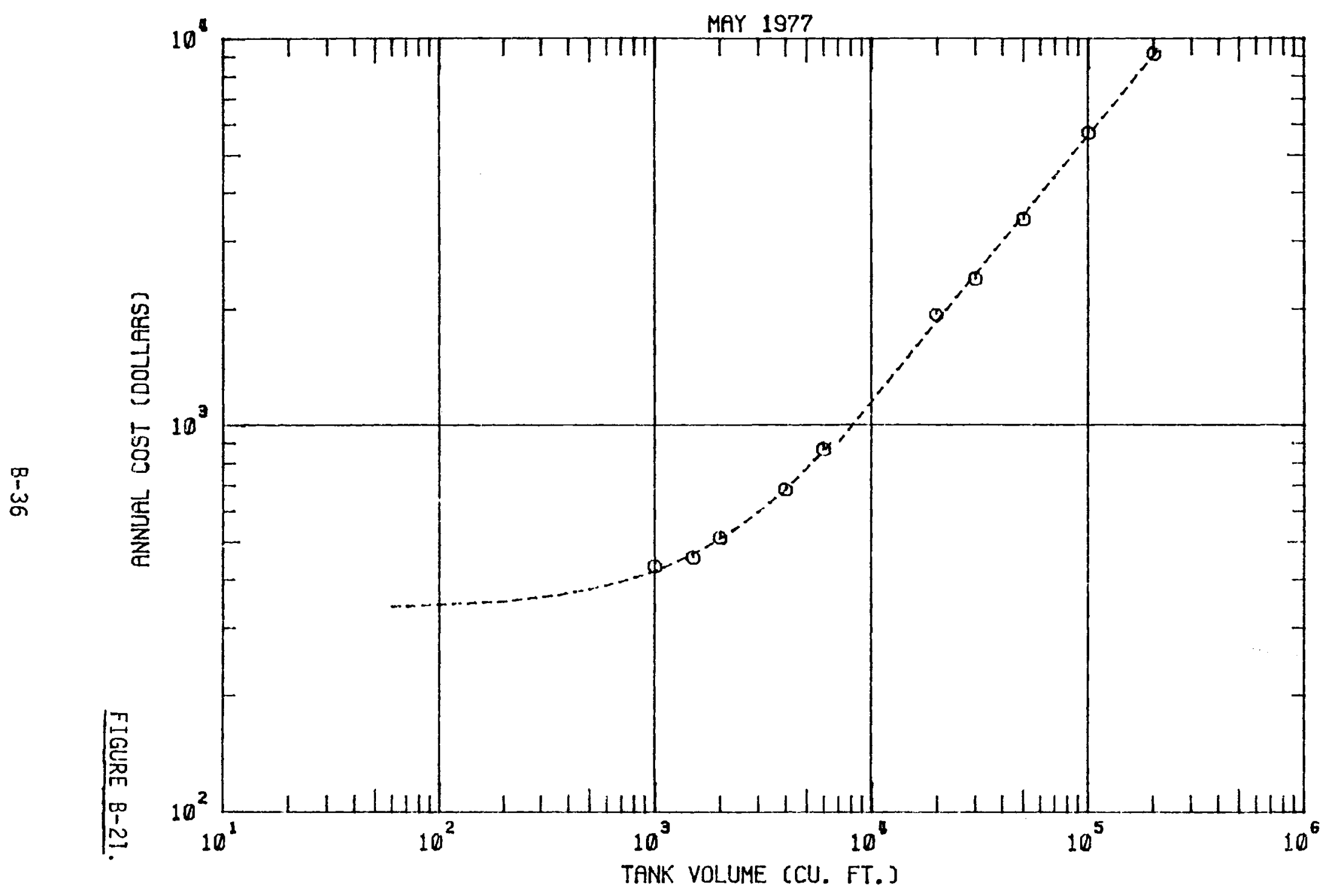

CONTACT TANK - MAINTENANCE MATERIAL AND SUPPLIES COSTS 


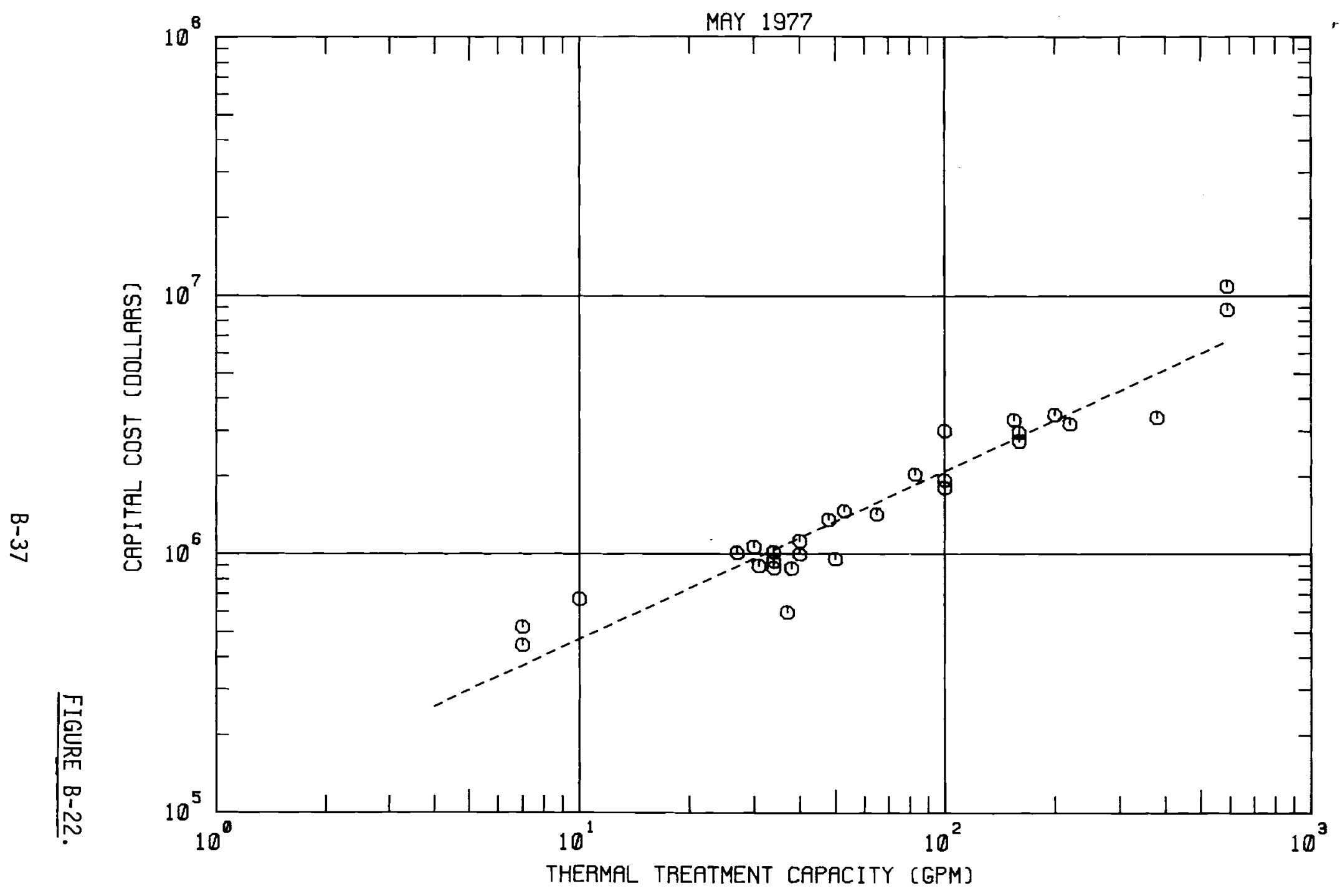

LOW PRESSURE WET AIR OXIDATION - CAPITAL COSTS 


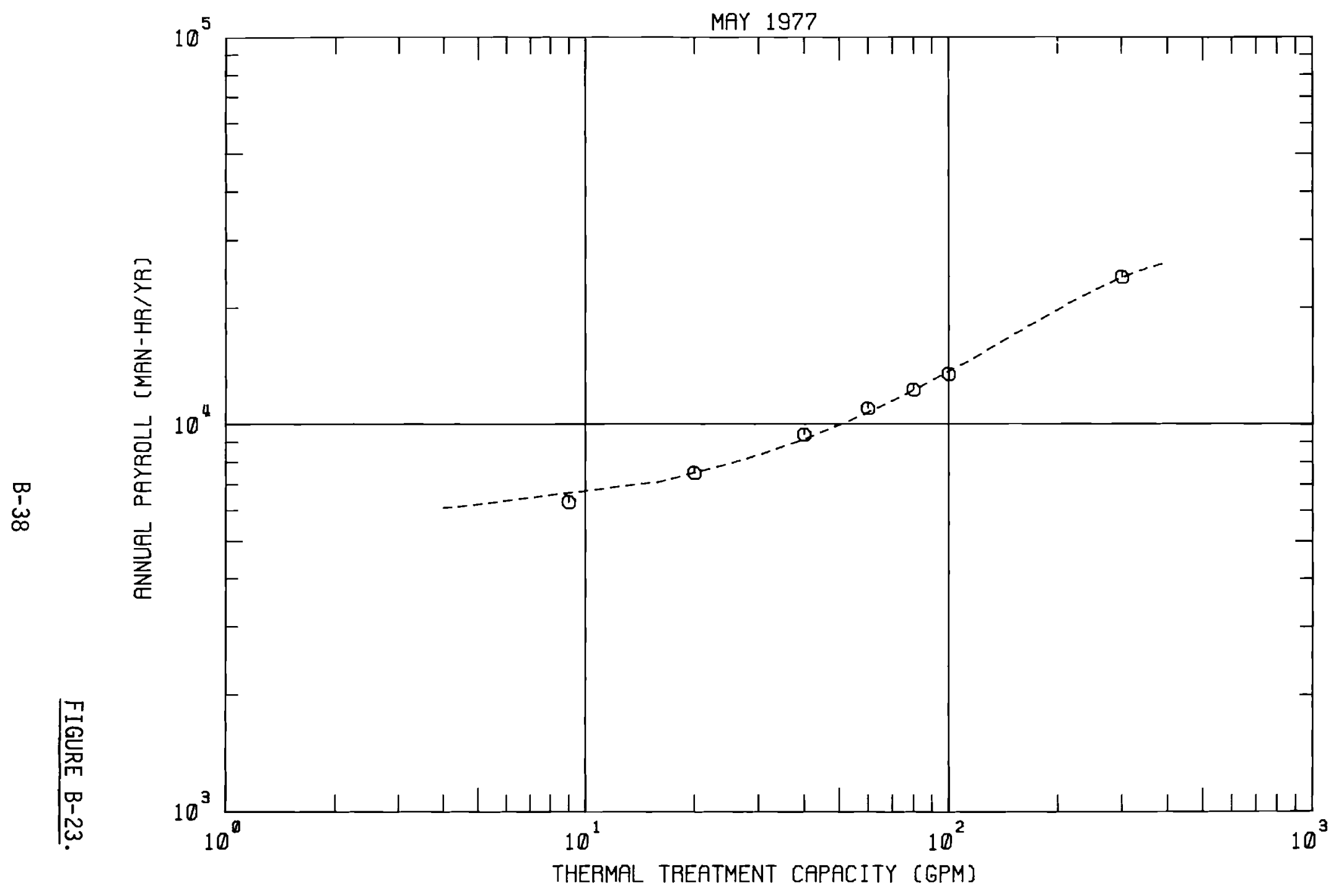

LOW PRESSURE WET AIR OXIDATION - LABOR REQUIREMENTS 


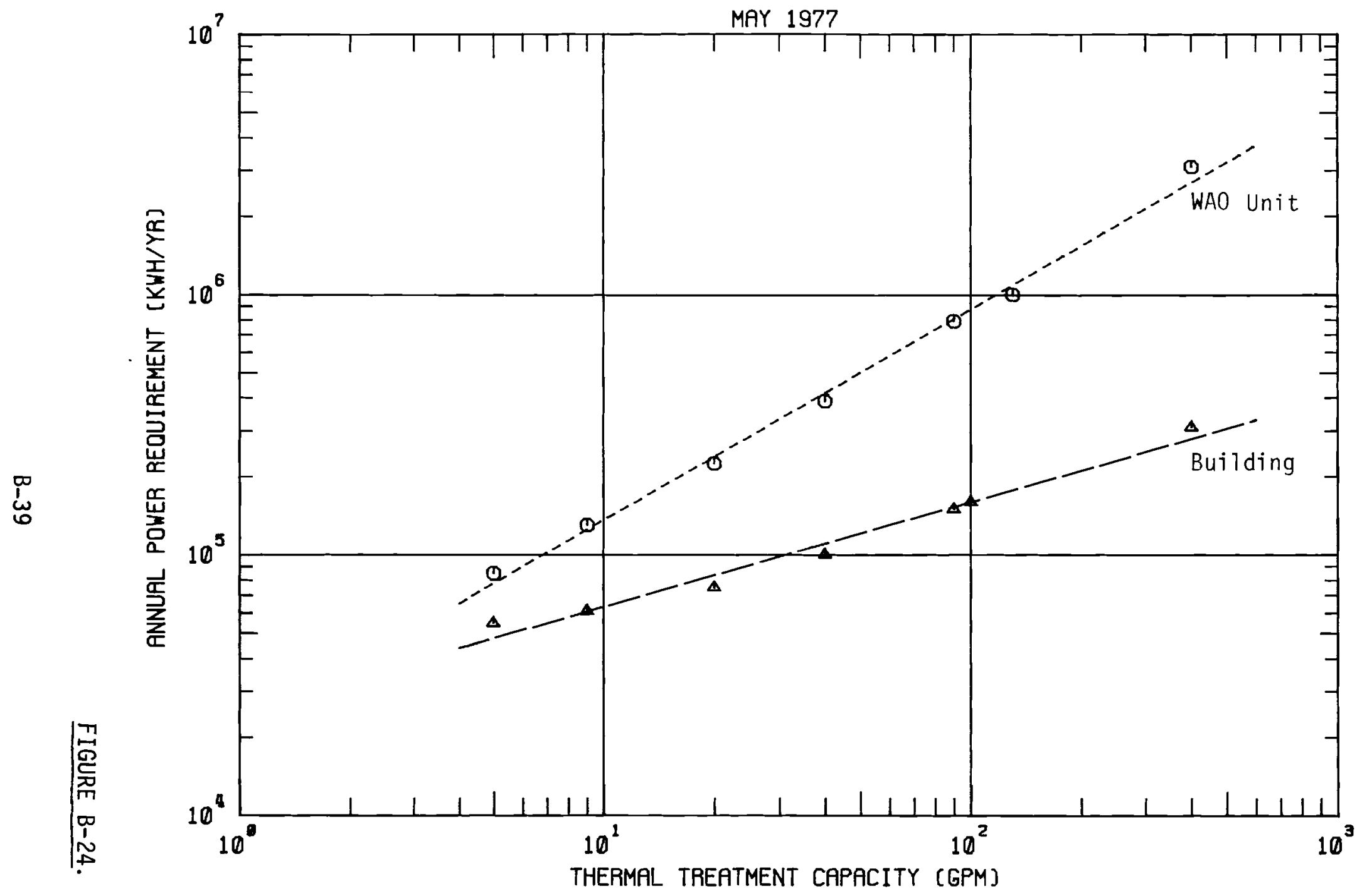

LOW PRESSURE WET AIR OXIDATION - POWER REQUIREMENTS 


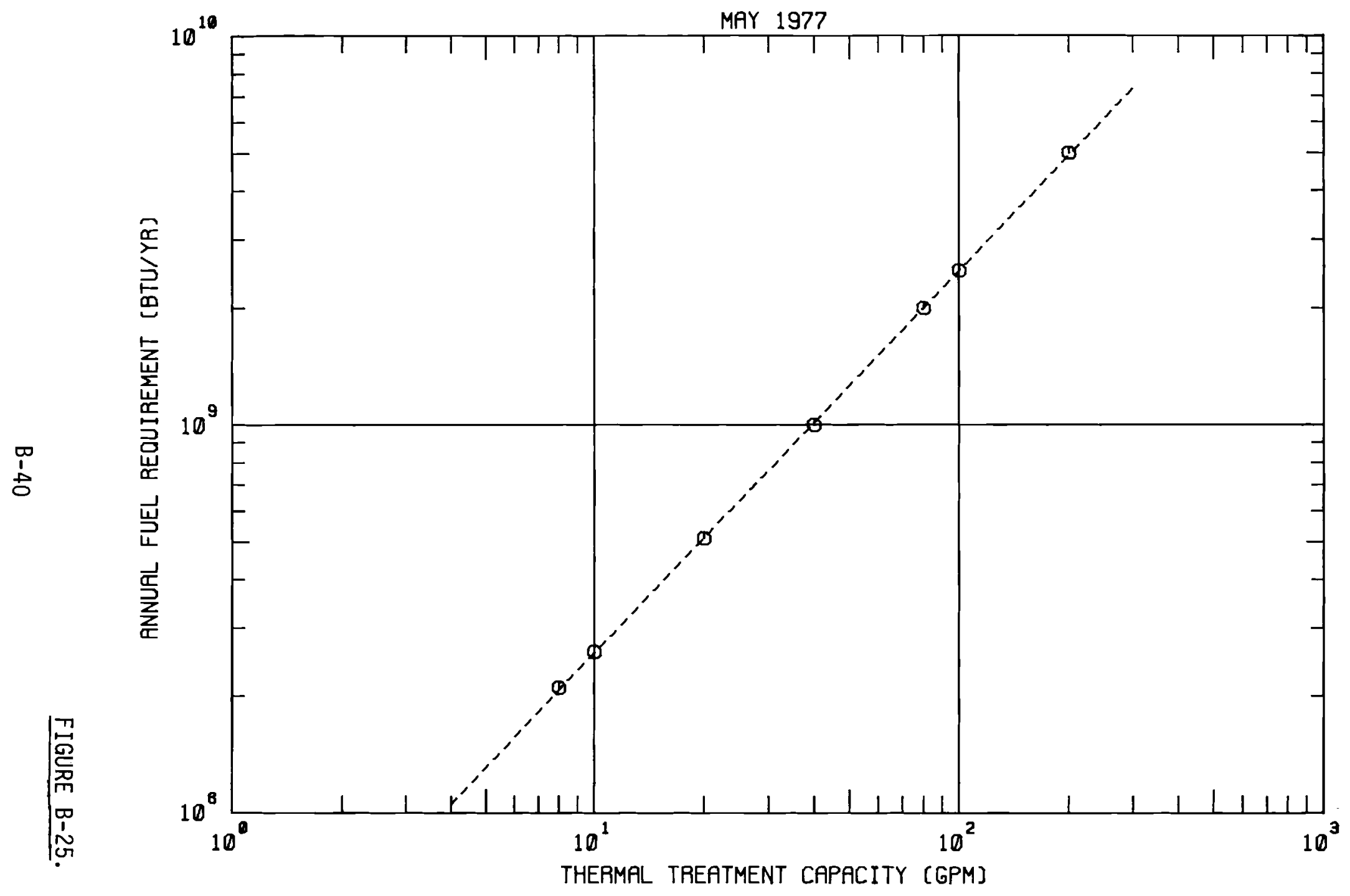

LOW PRESSURE WET AIR OXIDATION - FUEL REQUIREMENTS 


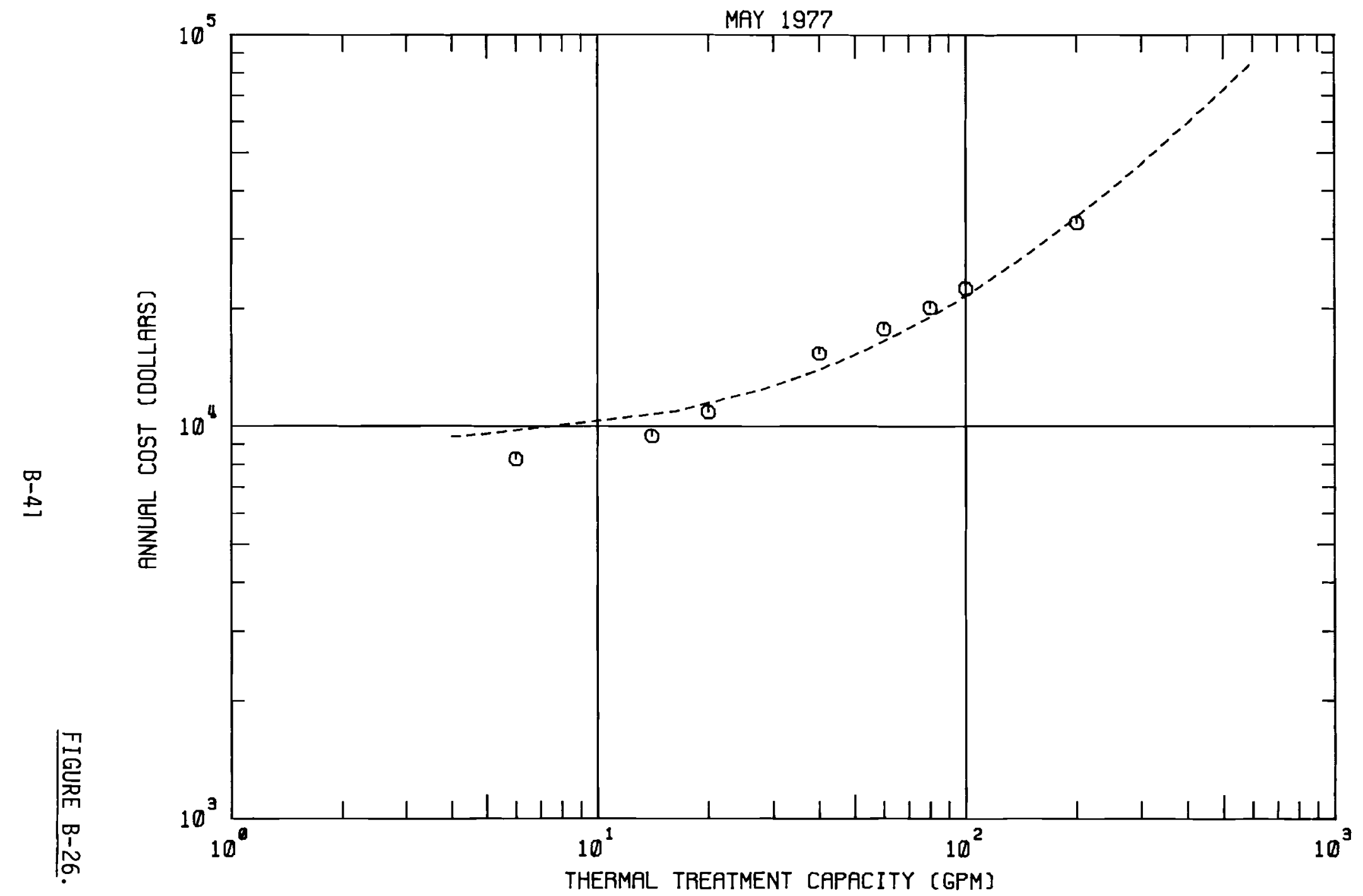

LOW PRESSURE WET AIR OXIDATION - MATERIAL AND SUPPLY COSTS 


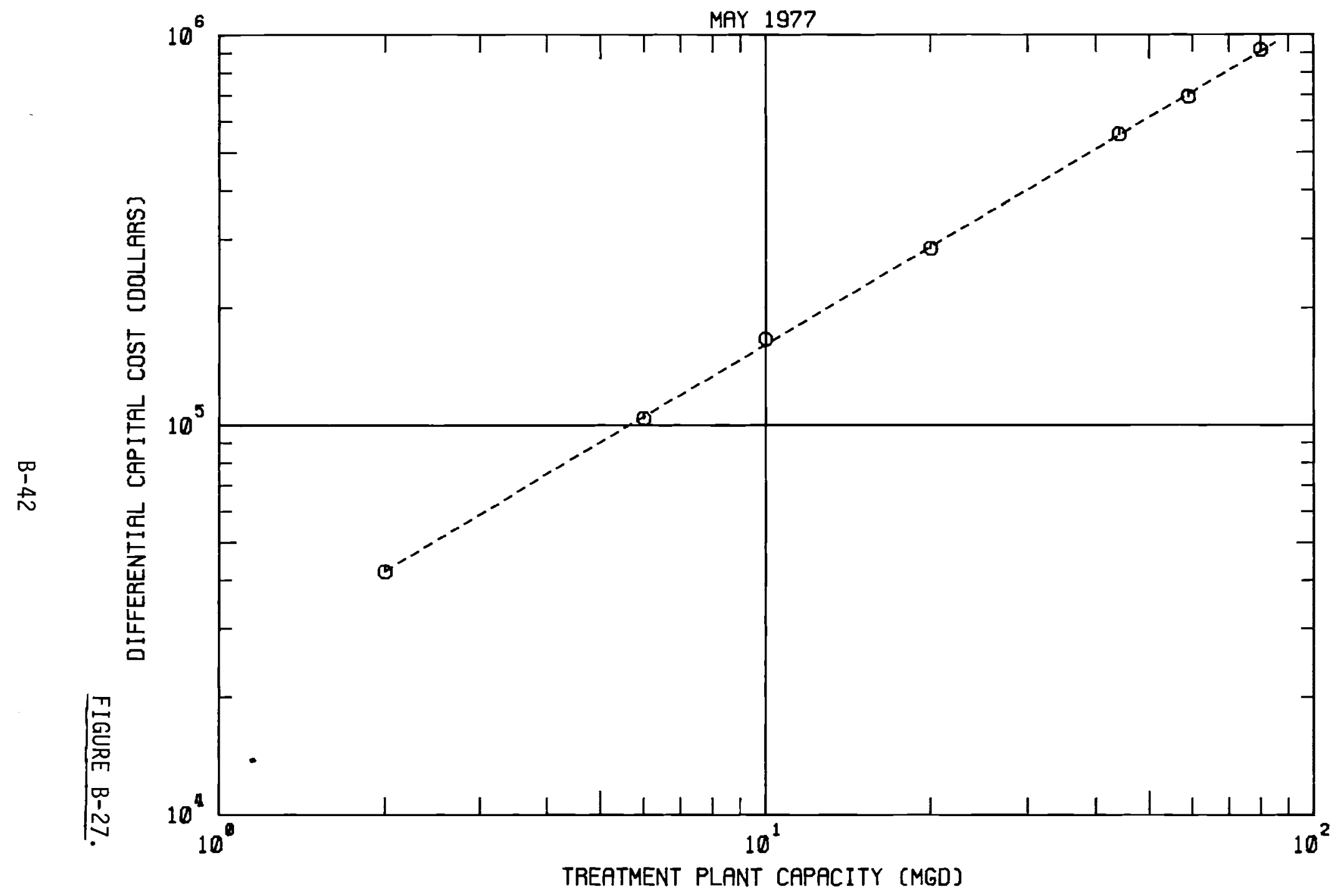

LOW PRESSURE WET AIR OXIDATION - INCREMENTAL CAPITAL COST OF RECYCLED LIOUOR TREATMENT 


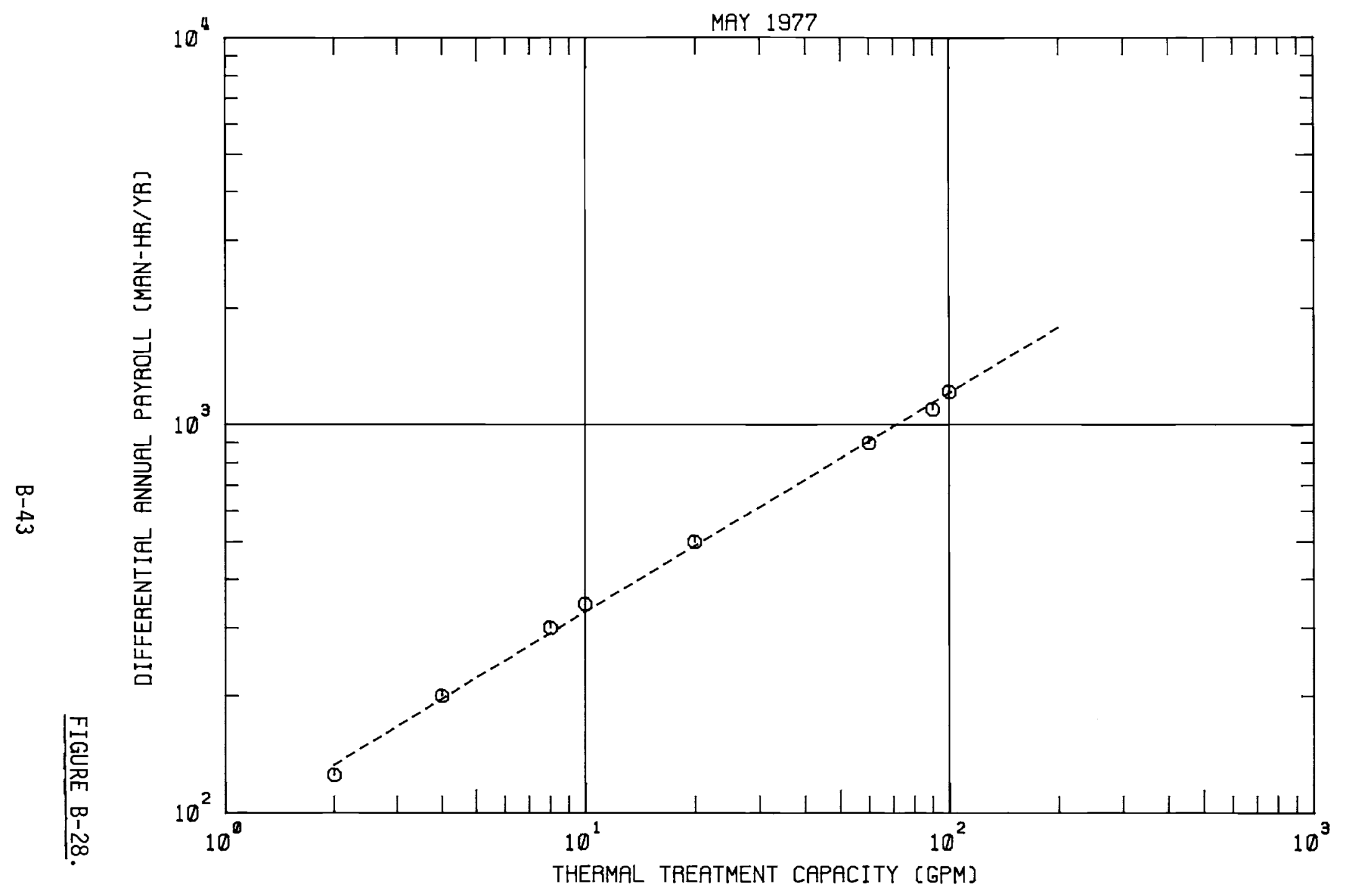

LOW PRESSURE WET AIR OXIDATION - INCREMENTAL LABOR REQUIREMENT FOR RECYCLED LIQUOR TREATMENT 


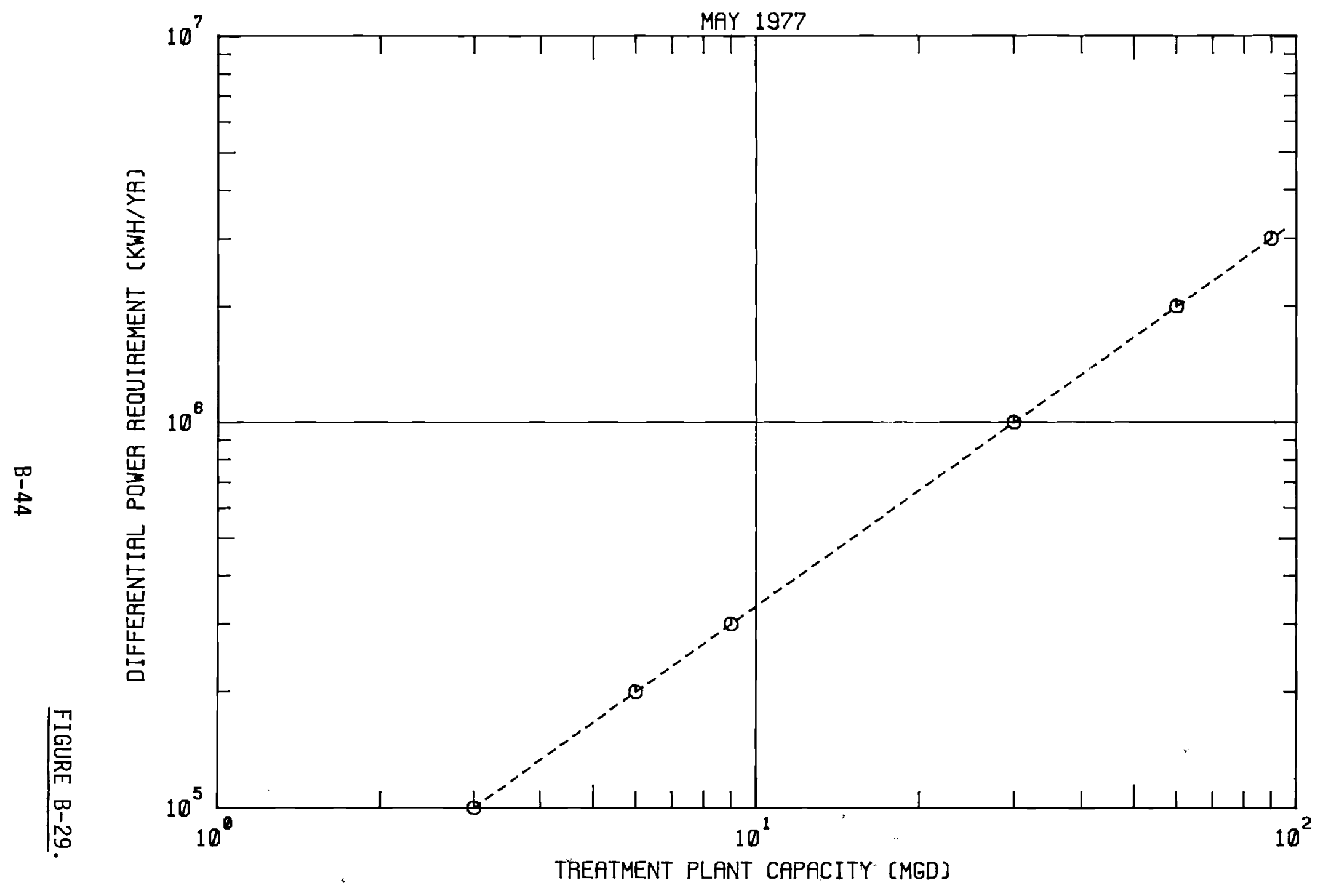

LOW PRESSURE WET AIR OXIDATION - INCREMENTAL POWER REQUIREMENT FOR RECYCLED LIQUUR TREATMENT 


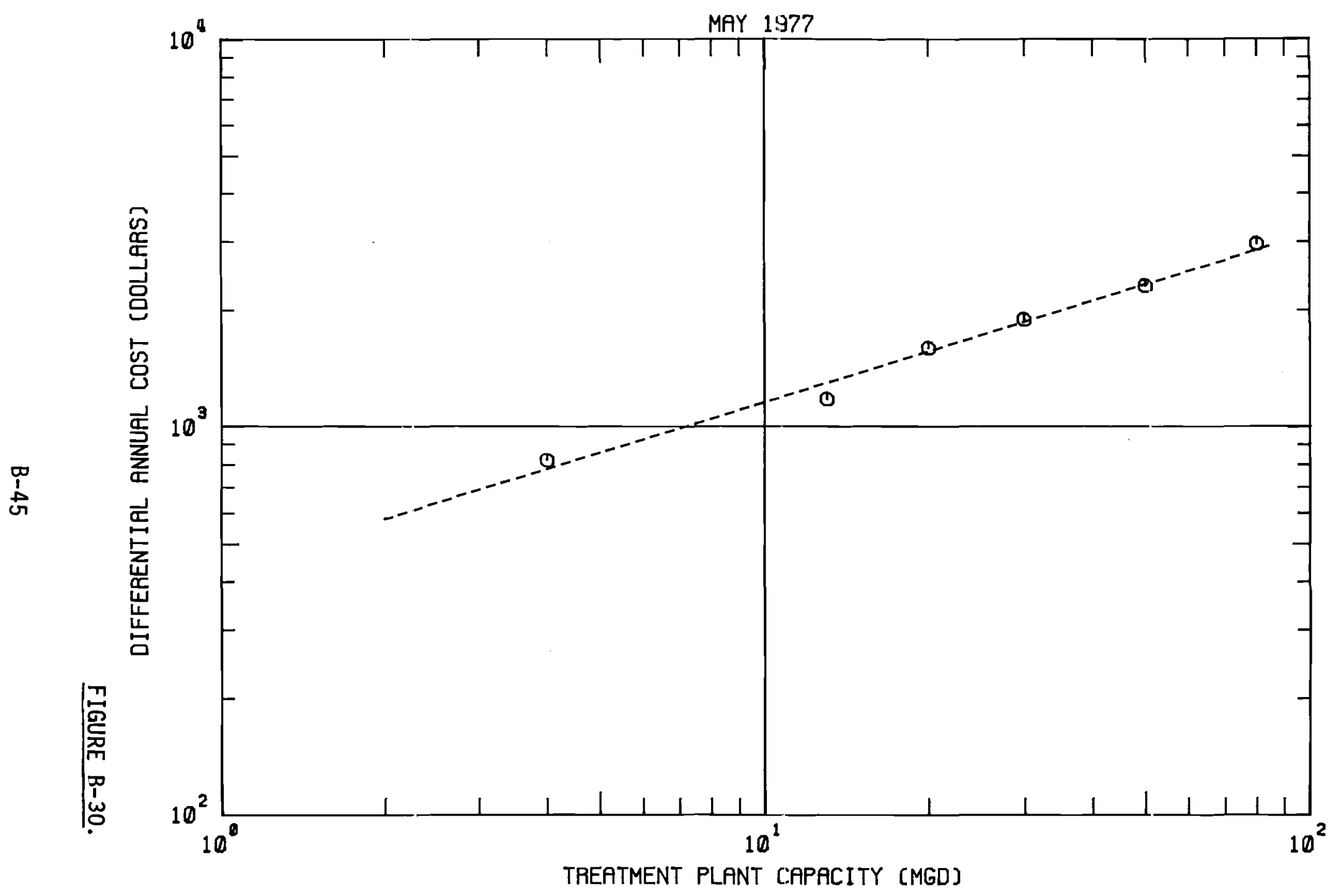

LOW PRESSURE WET AIR OXIDATION - INCREMENTAL MATERIAL AND SUPPLIES COST FOR RECYCLED LIQUOR TREATMENT 


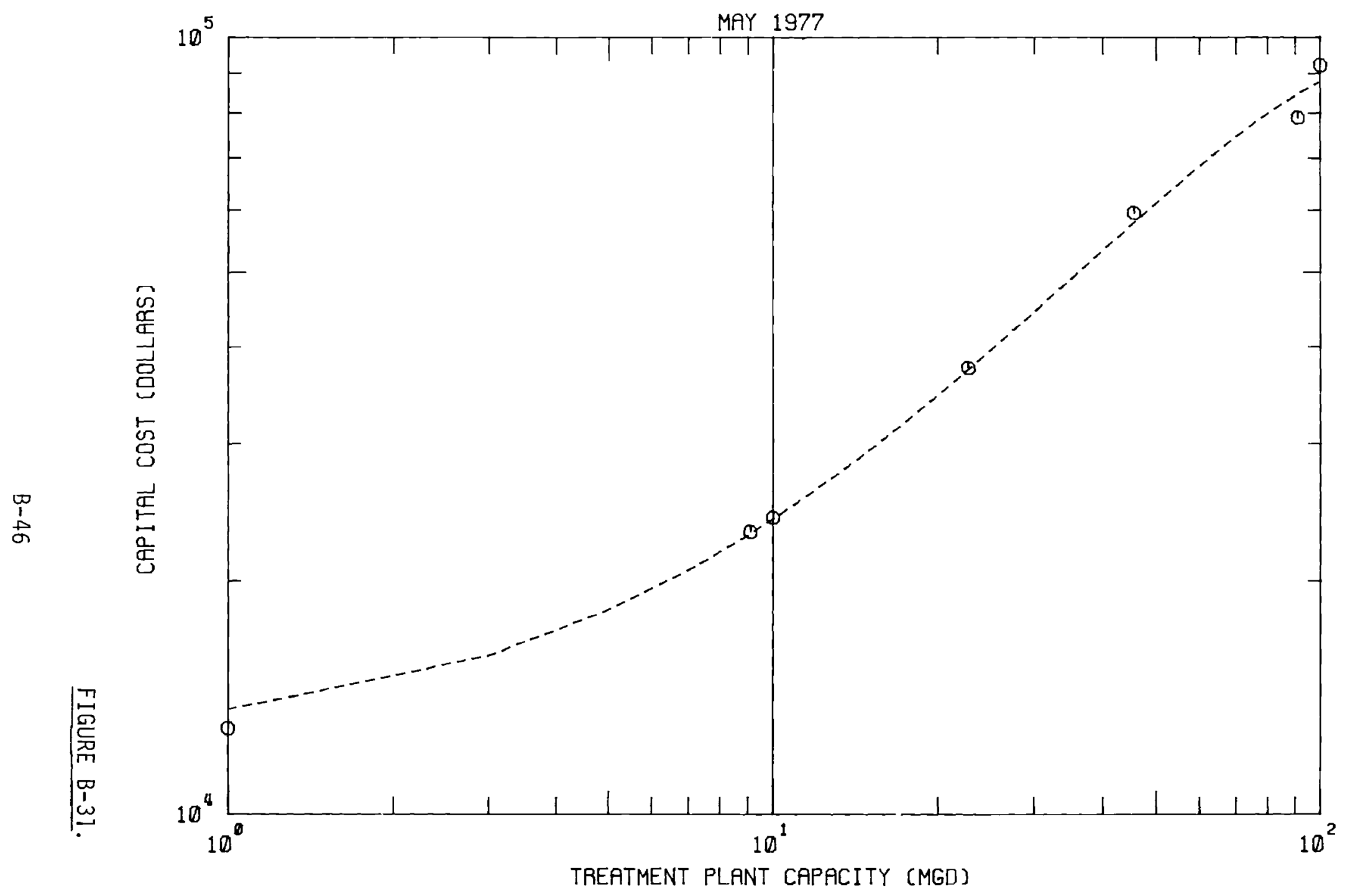

LOW PRESSURE WET AIR OXIDATION - CAPITAL COSTS FOR ODOR CONTROL BY CHEMICAL SCRUBBING 


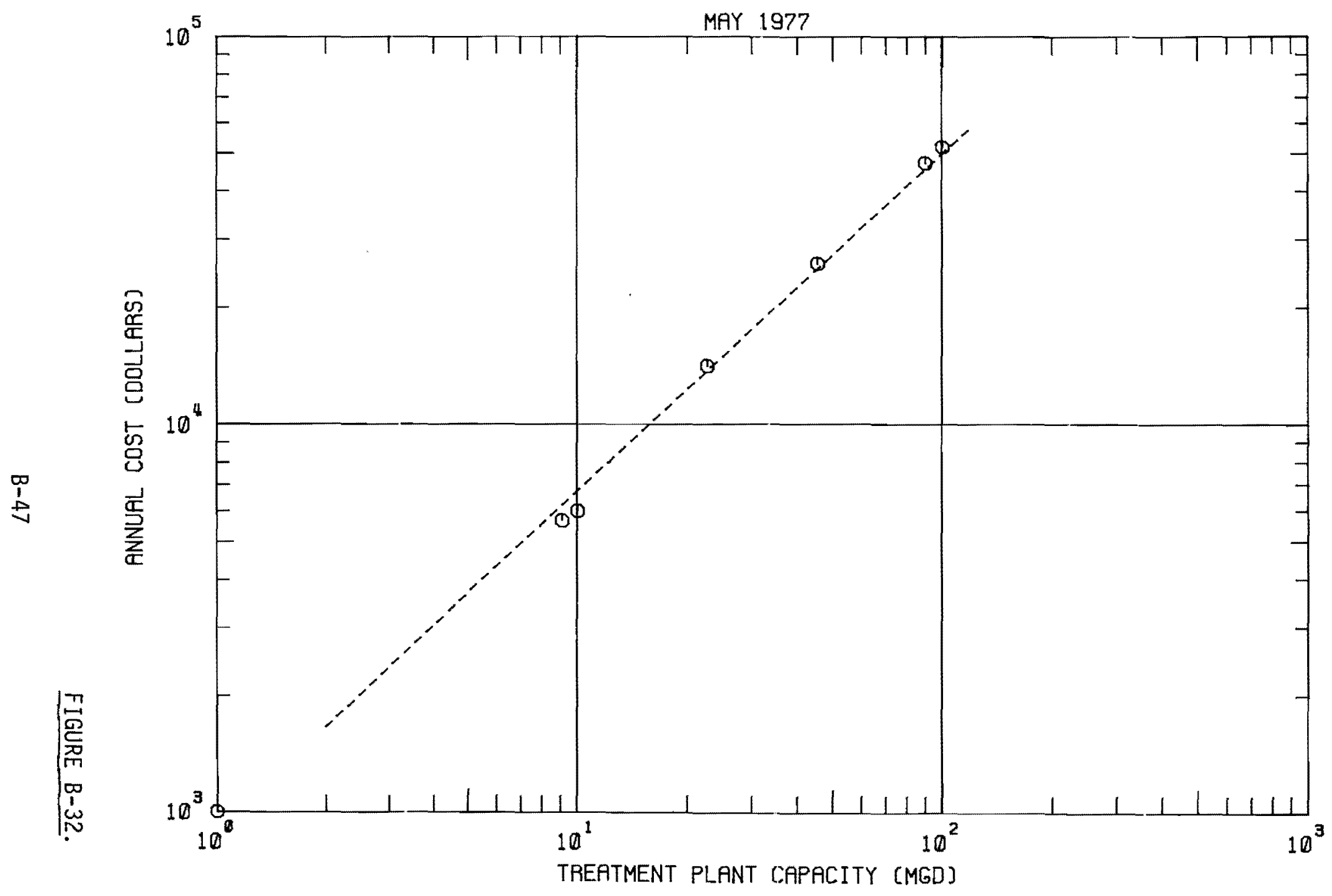

LOW PRESSURE WET AIR OXIDATION - OPERATION AND MAINTENANCE COST FOR ODOR CONTROL BY CHEMICAL SCRUBBING 


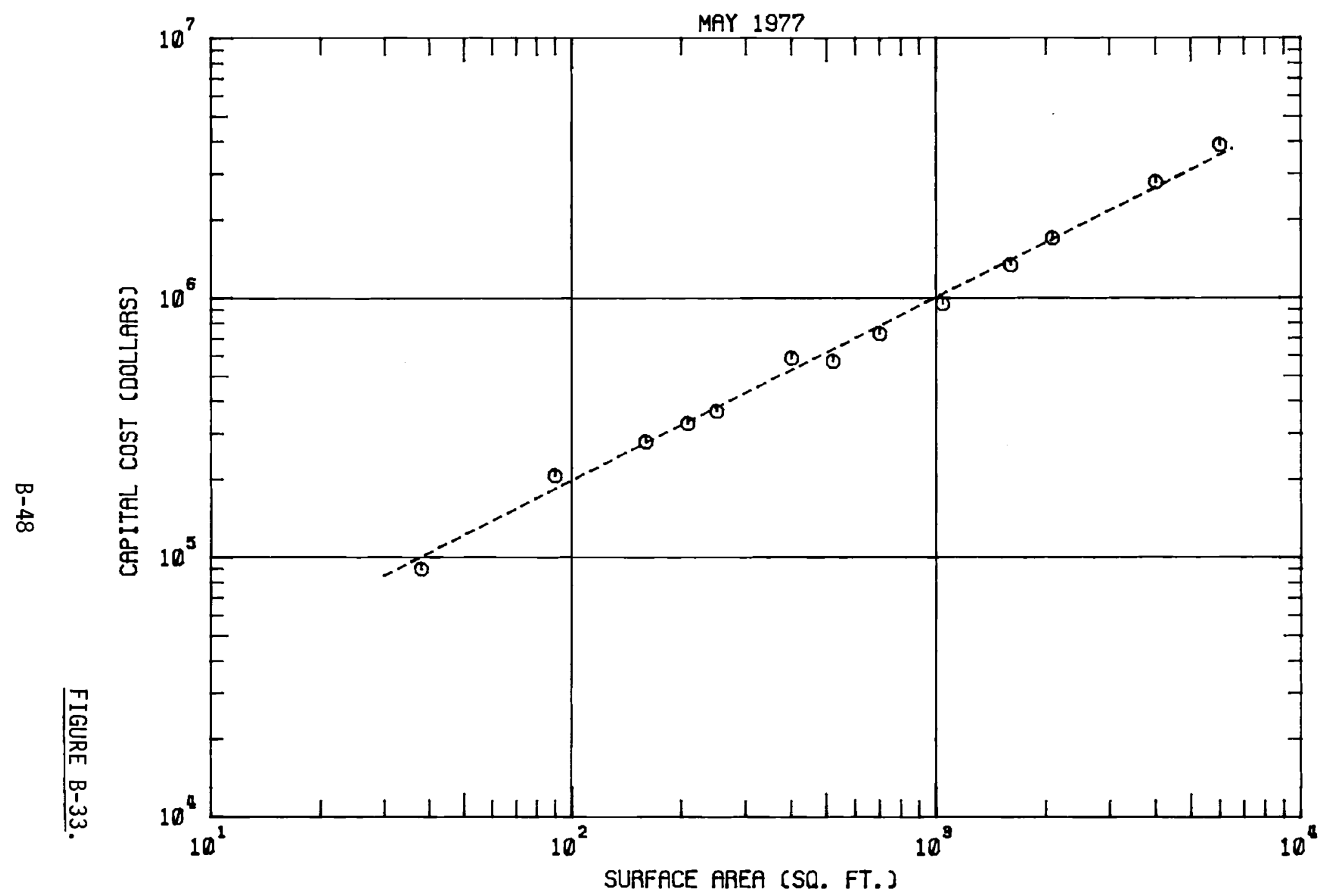

VACUUM FILTRATION - CAPITAL COSTS 


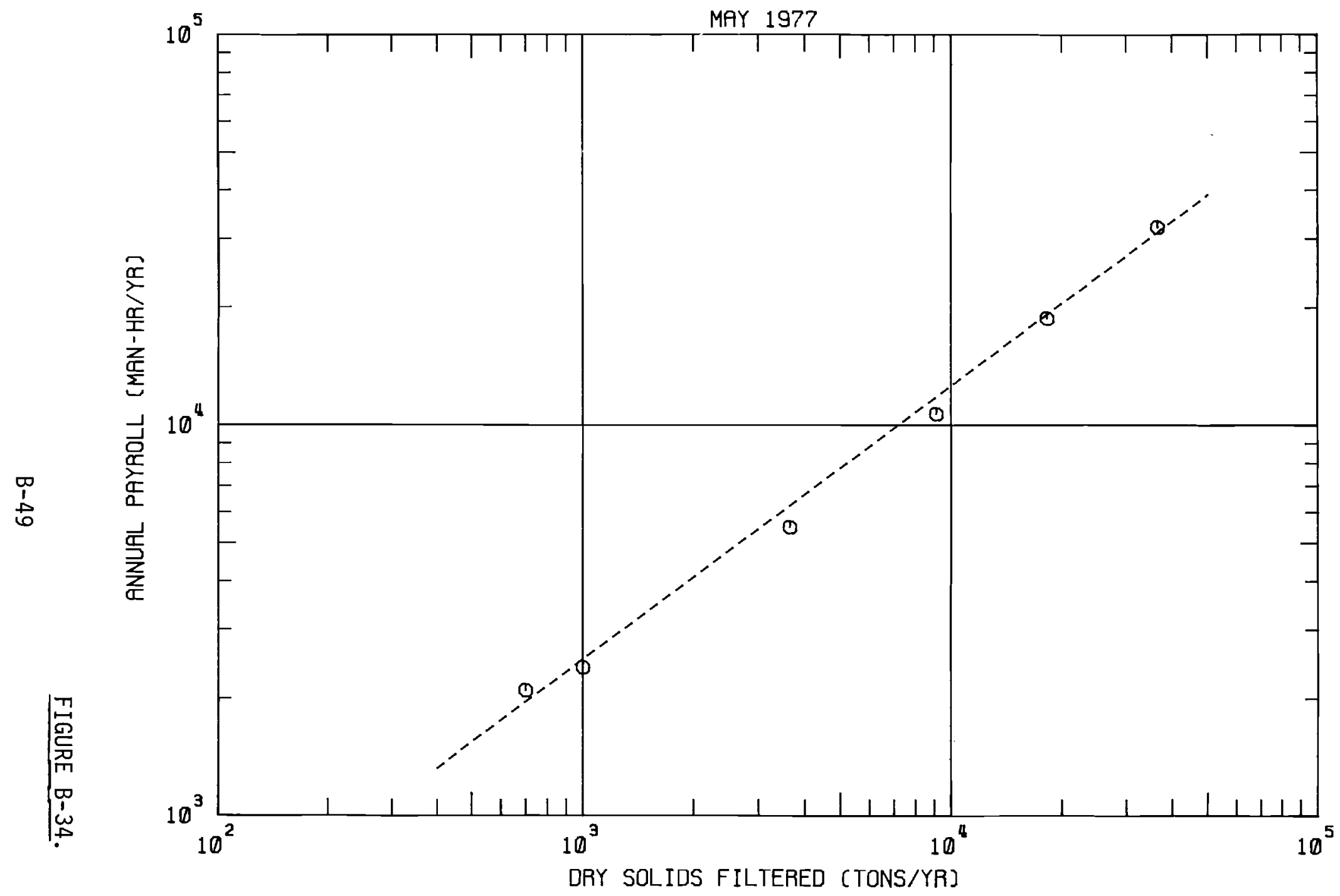

VACUUM FILTRATION - LABOR REQUIREMENTS 


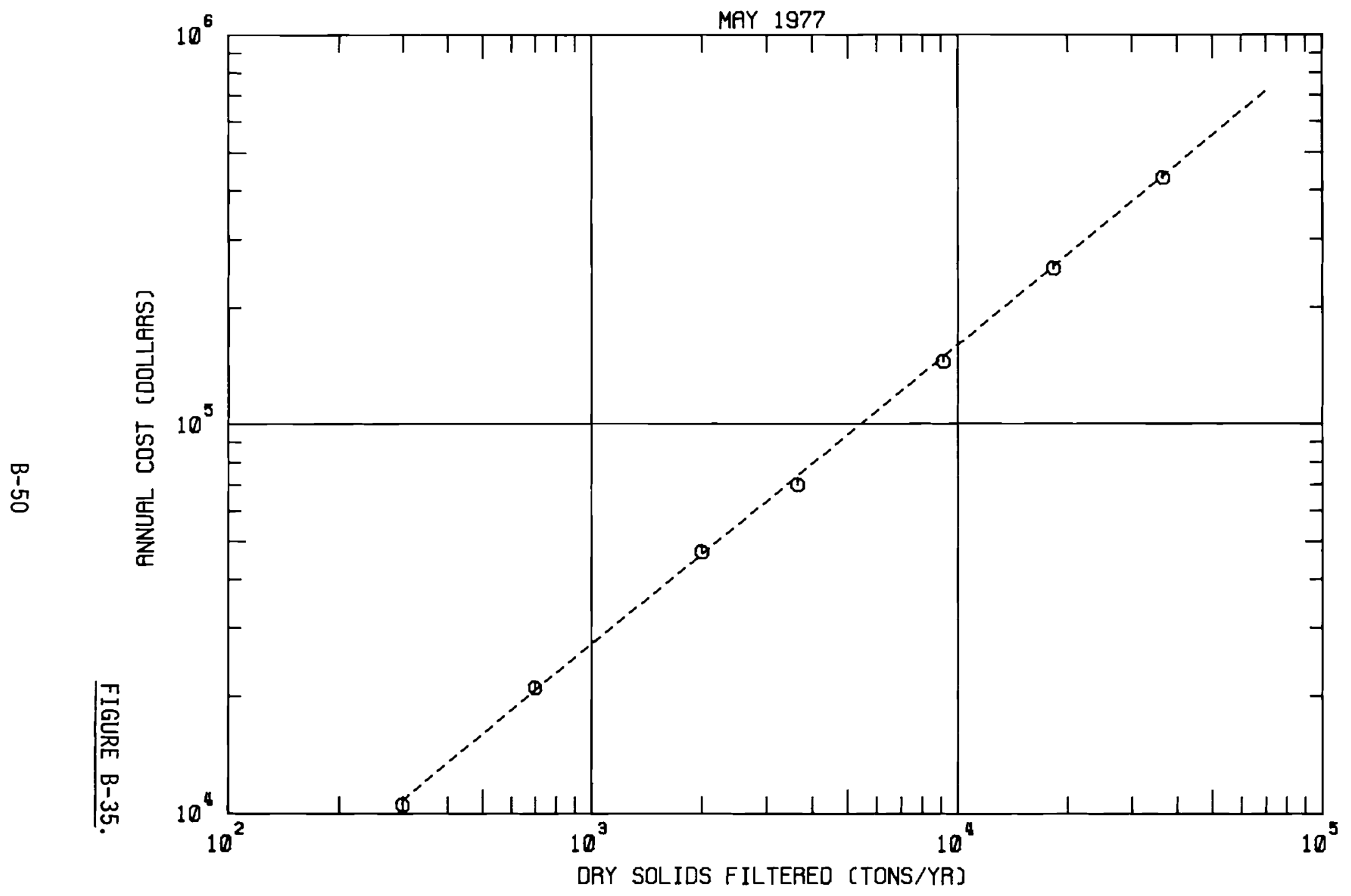

VACUUM FILTRATION - MAINTENANCE MATERIAL AND SUPPLIES COSTS 


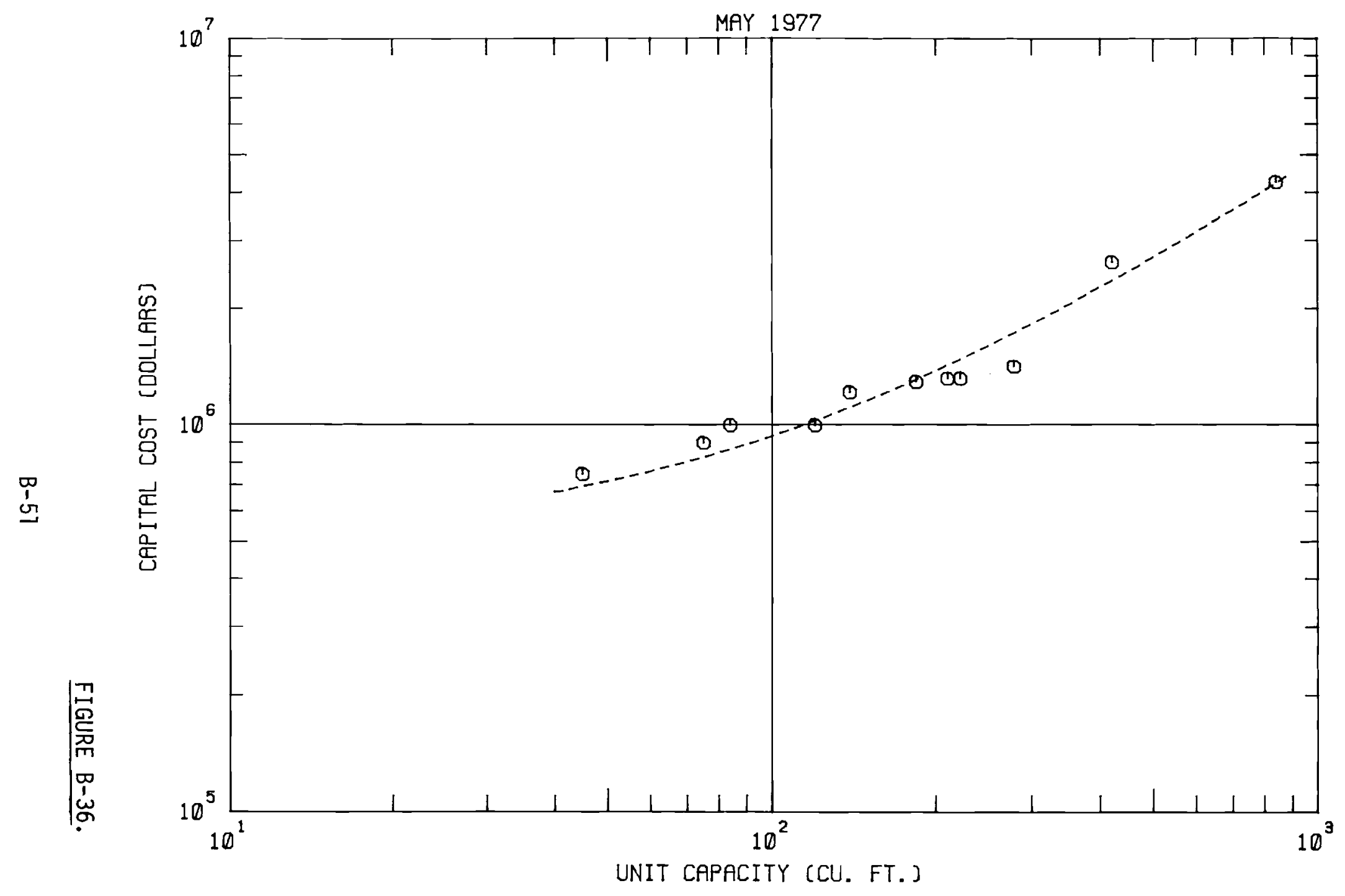

FILTER PRESS - CAPITAL COSTS 


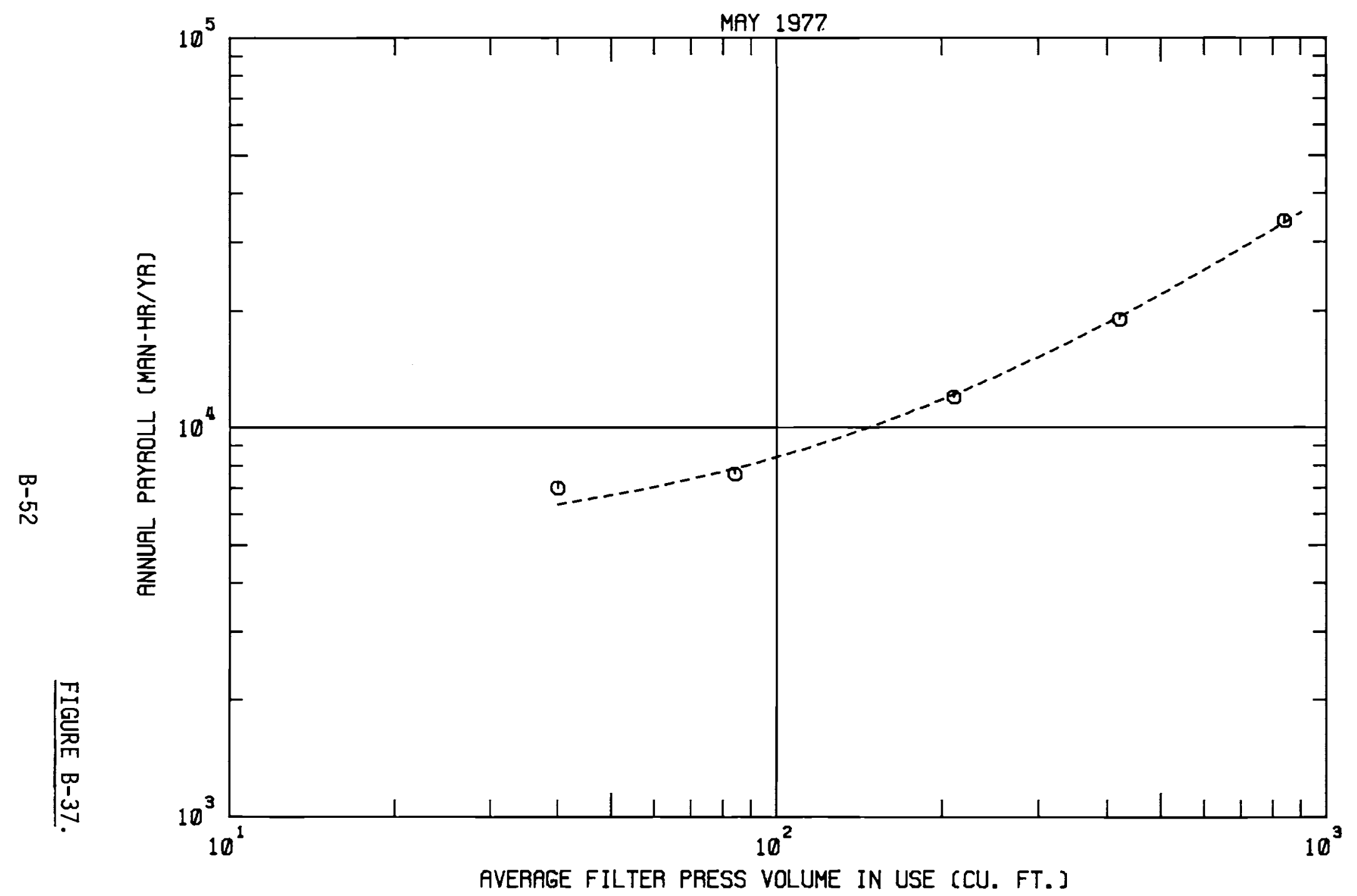

FILTER PRESS - LABOR REQUIREMENTS 


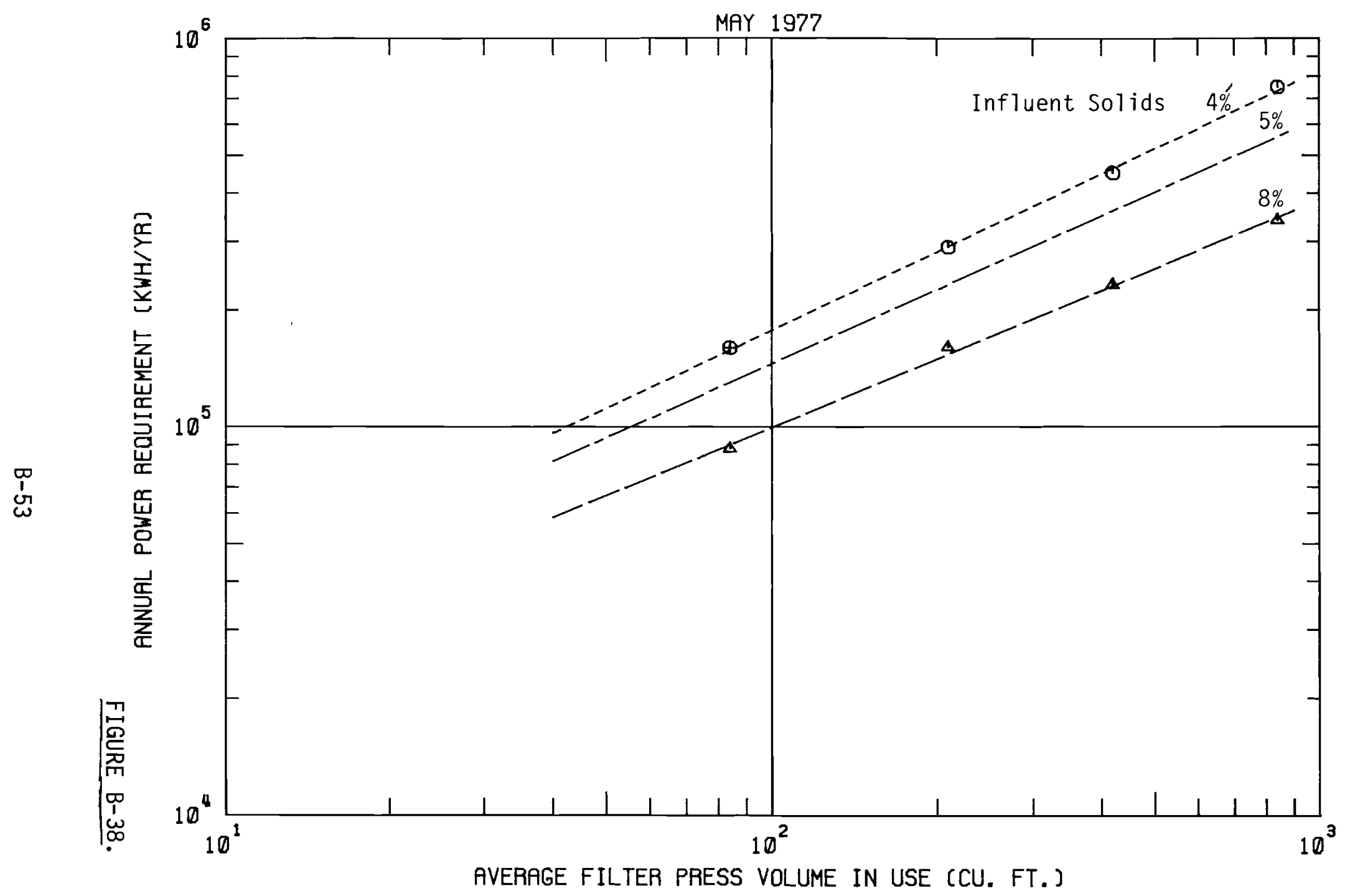

FILTER PRESS - POWER REQUIREMENTS 


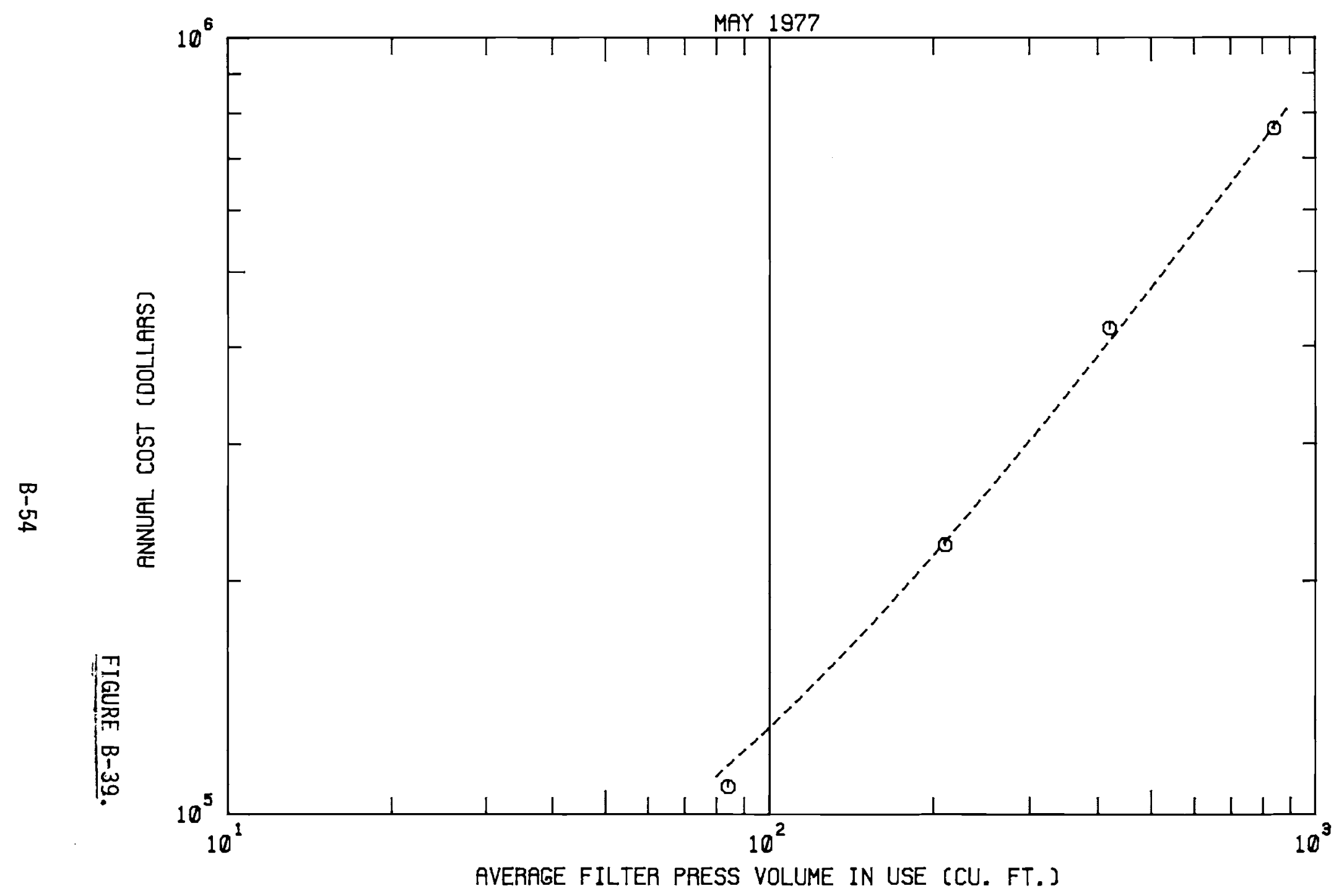

FILTER PRESS - MAINTENANCE MATERIAL AND SUPPLIES COSTS 


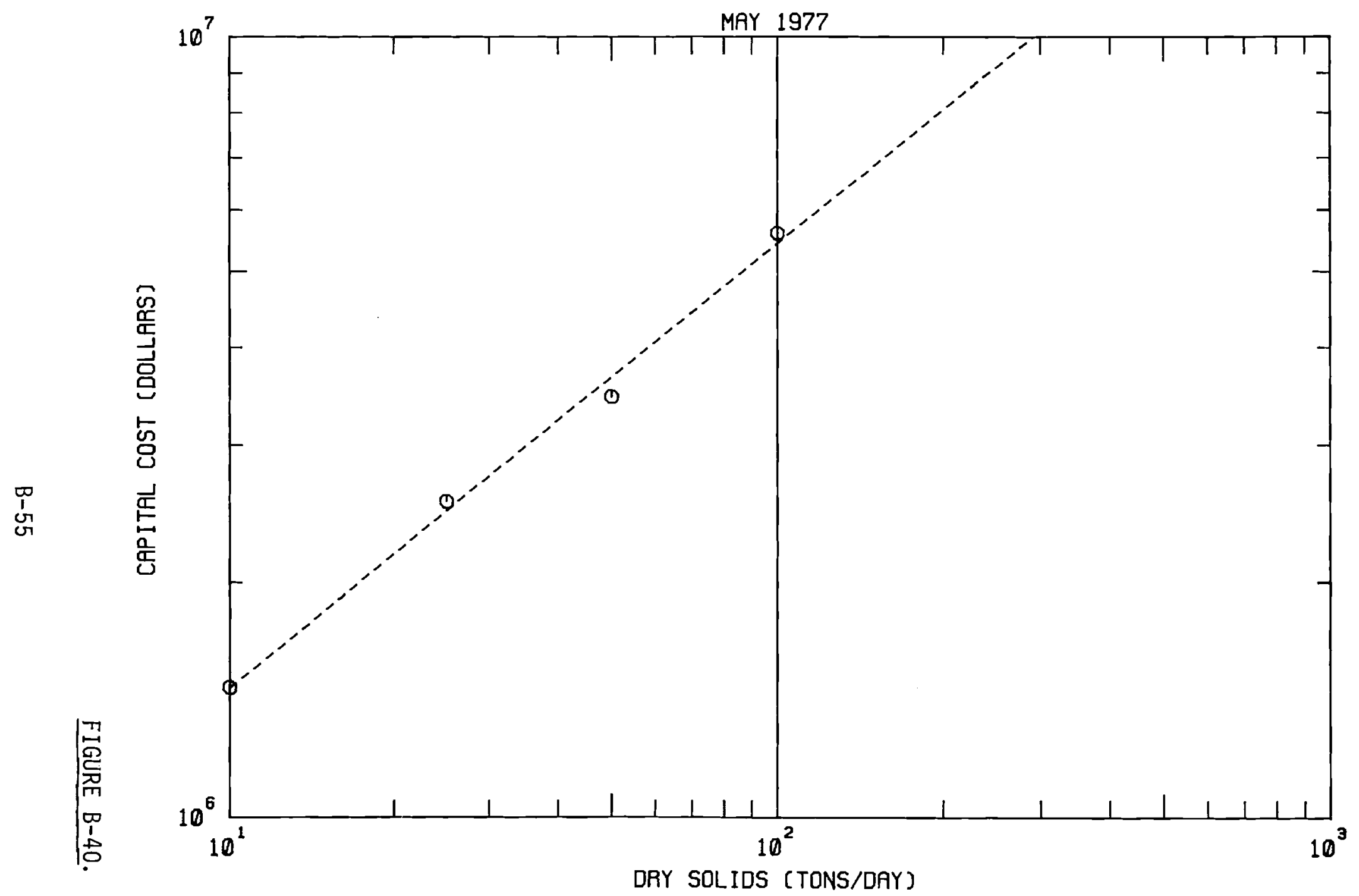

FLASH DRYING - CAPITAL COSTS 


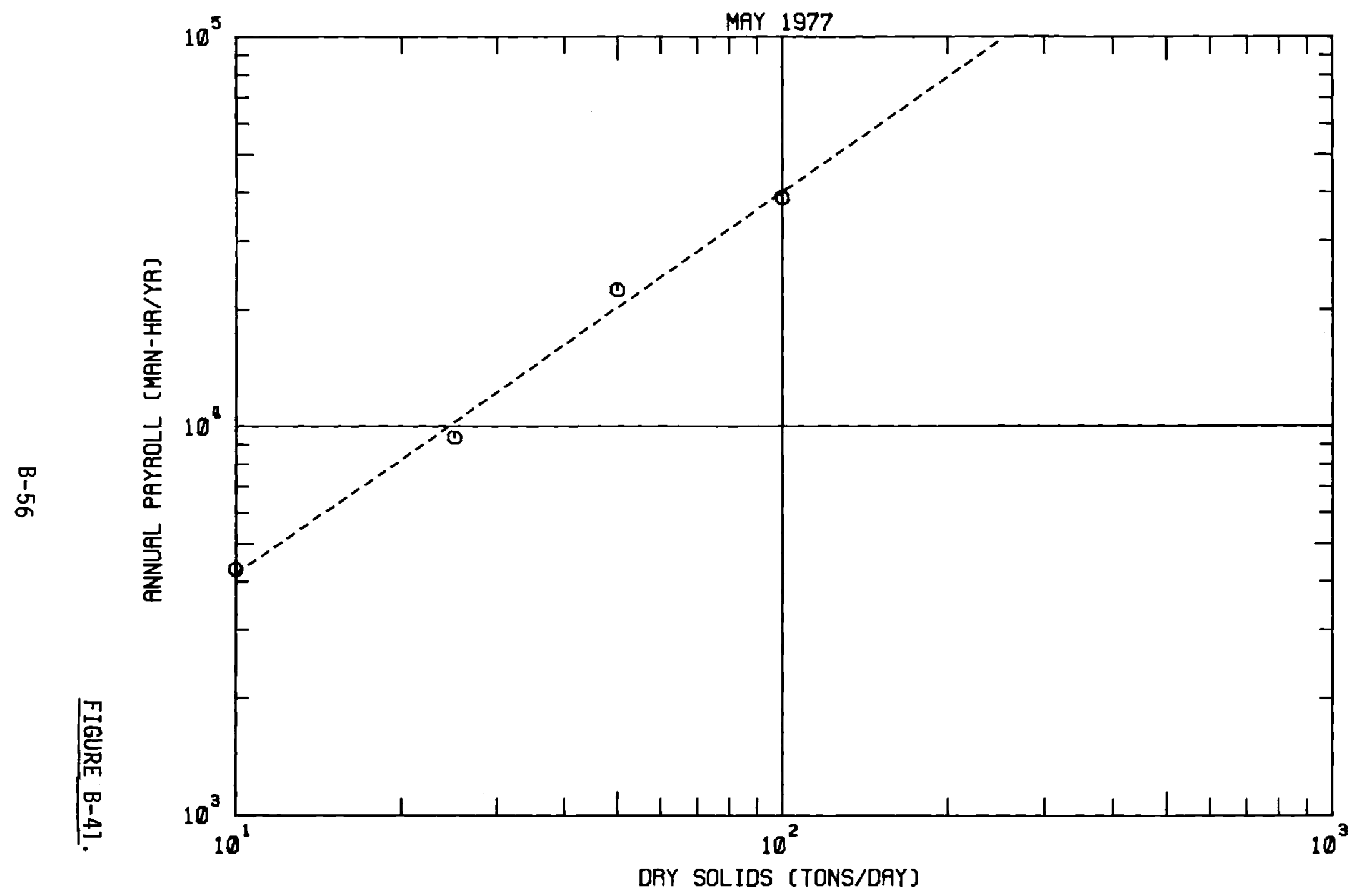

FLASH DRYING - LABOR REQUIREMENTS 


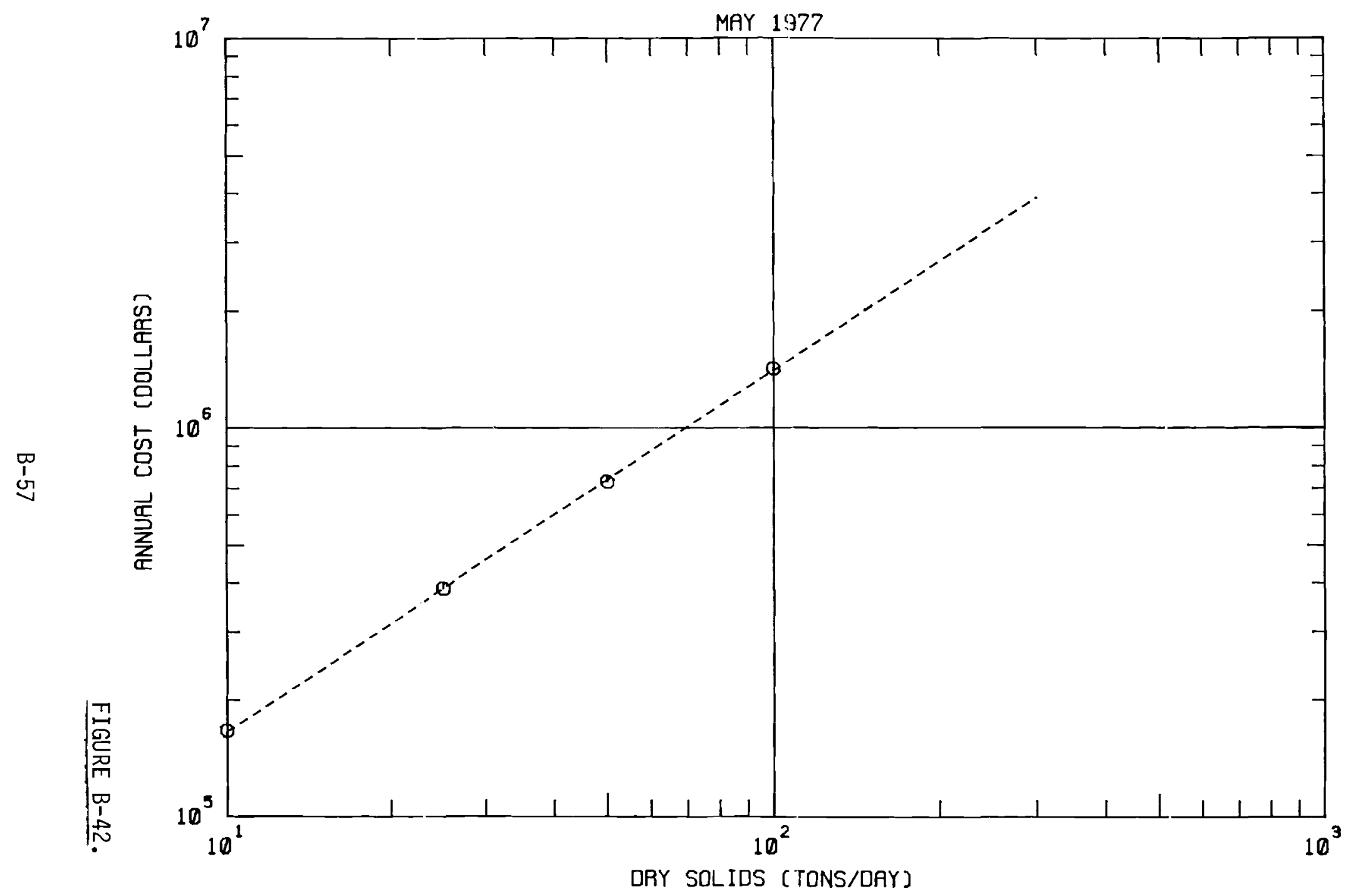

FLASH DRYING - OPERATION AND MAINTENANCE COSTS 


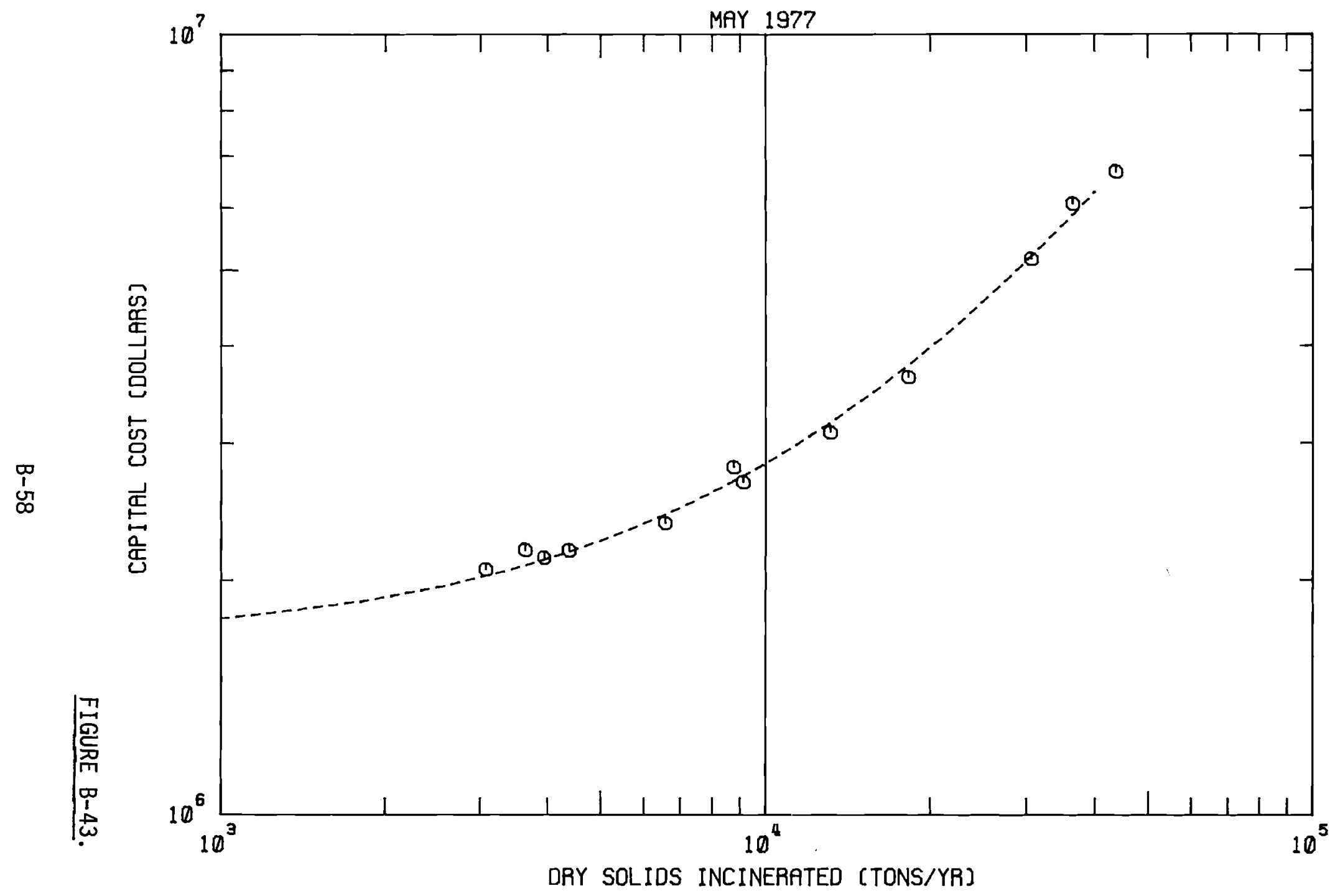

MULTIPLE HEARTH INCINERATION - CAPITAL COSTS 


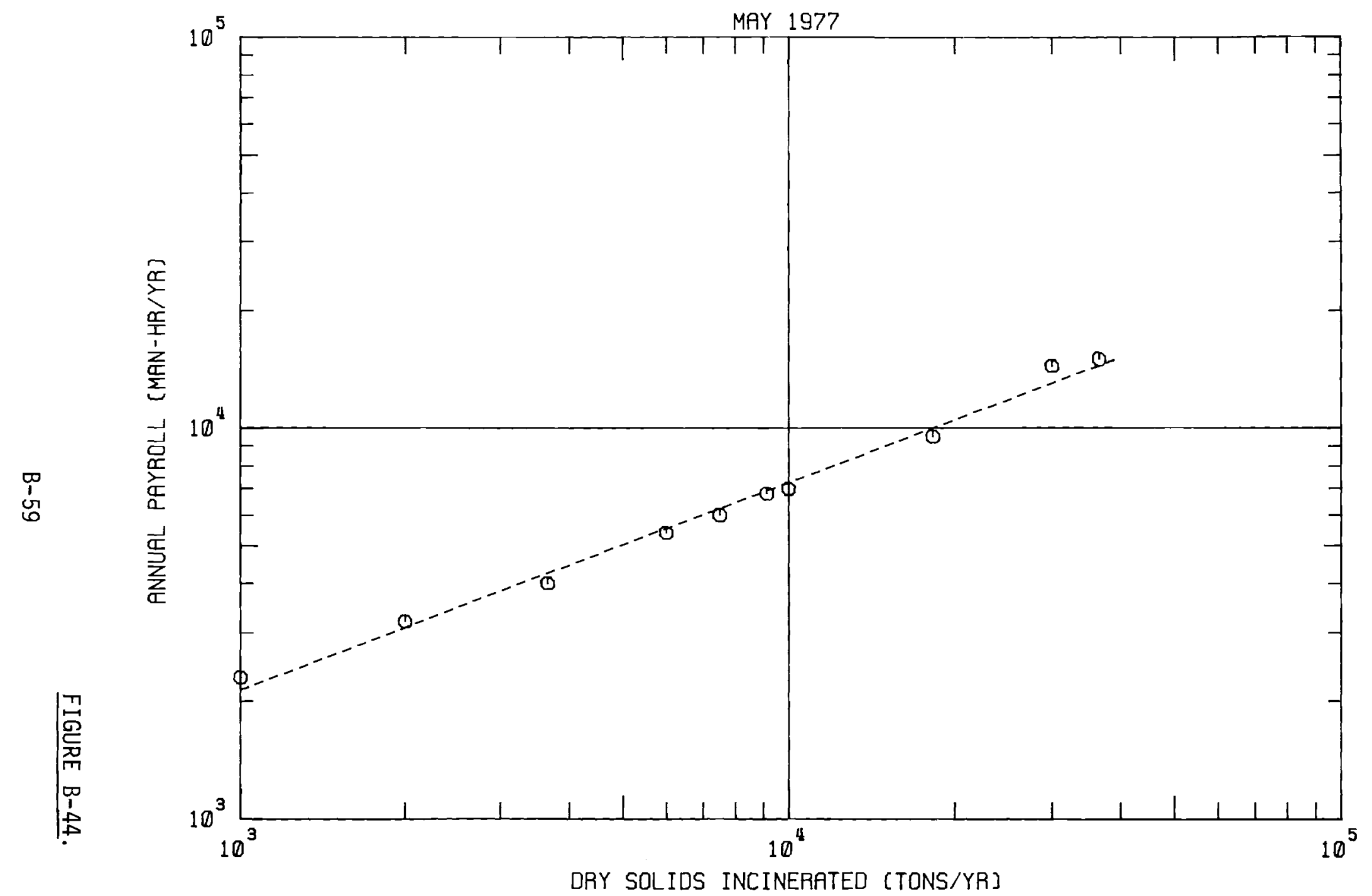

MULTIPLE HEARTH INCINERATION - LABOR REQUIREMENTS 


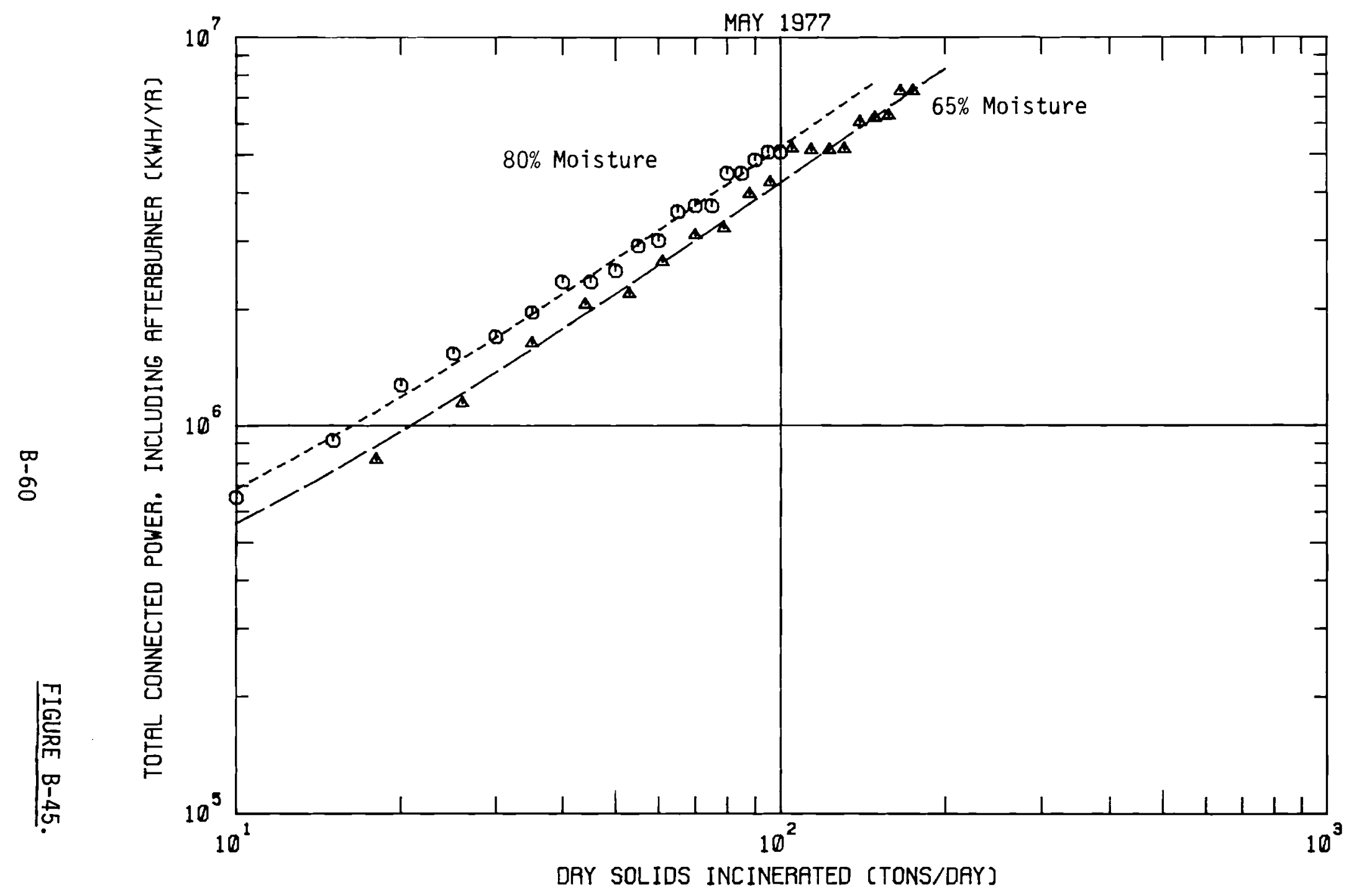

MULTIPLE HEARTH INCINERRTION - POWER REQUIREMENTS 


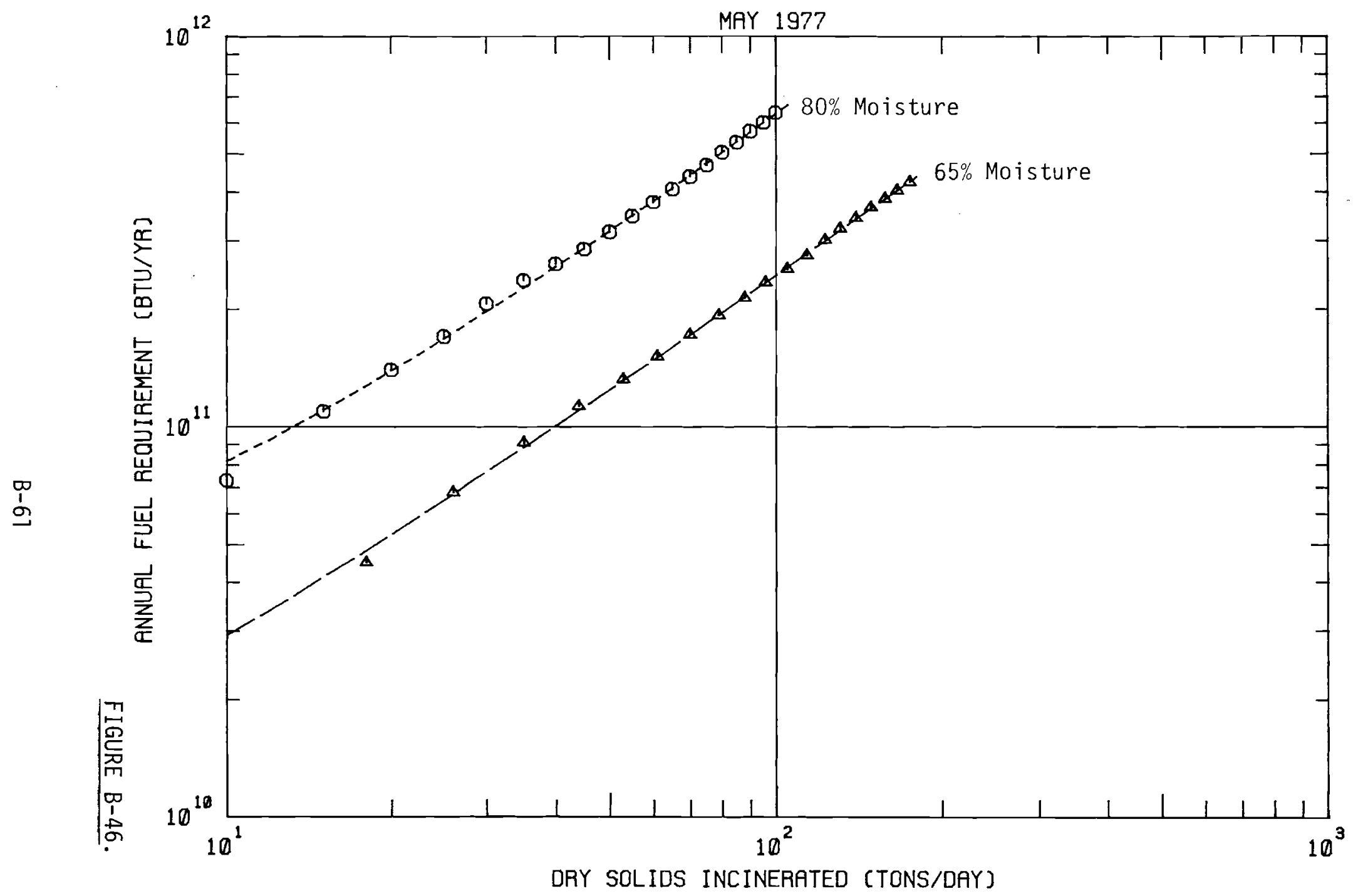

MULTIPLE HEARTH INCINERATION - FUEL REQUIREMENTS 


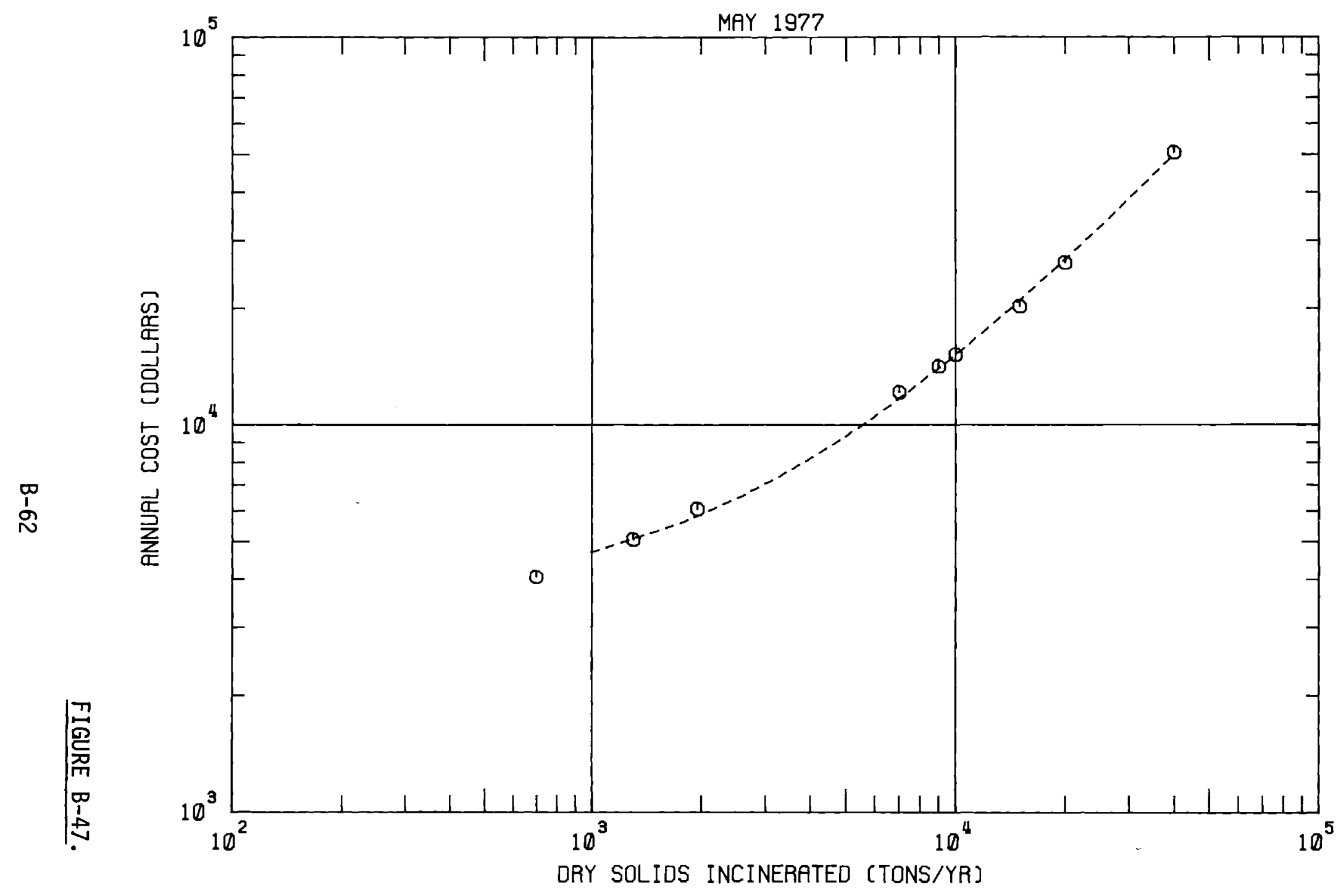

MULTIPLE HEARTH INCINERATION - MAINTENANCE MATERIAL AND SUPPLIES COSTS 


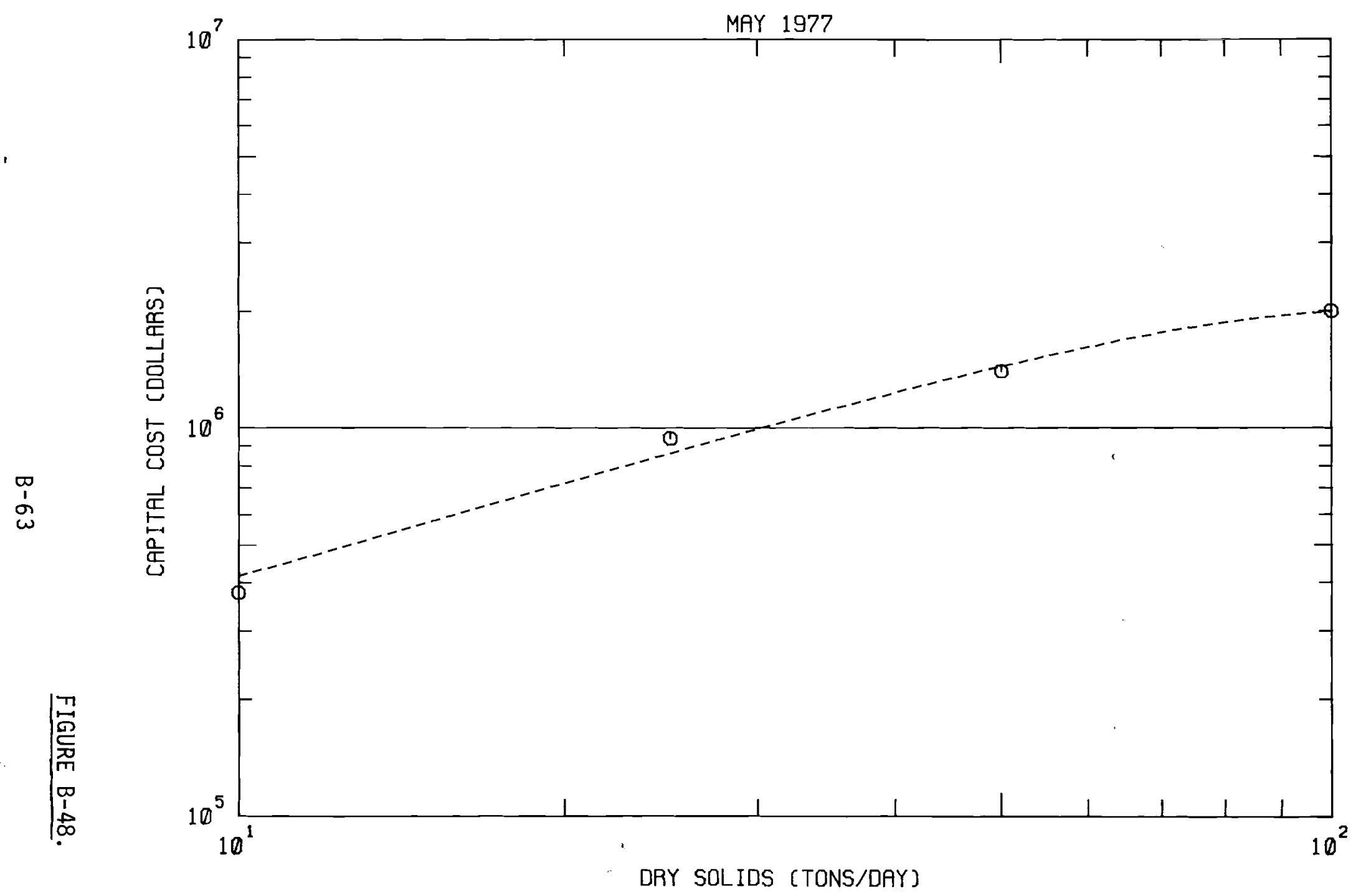

STATIC PILE COMPOSTING - CAPITAL COSTS 


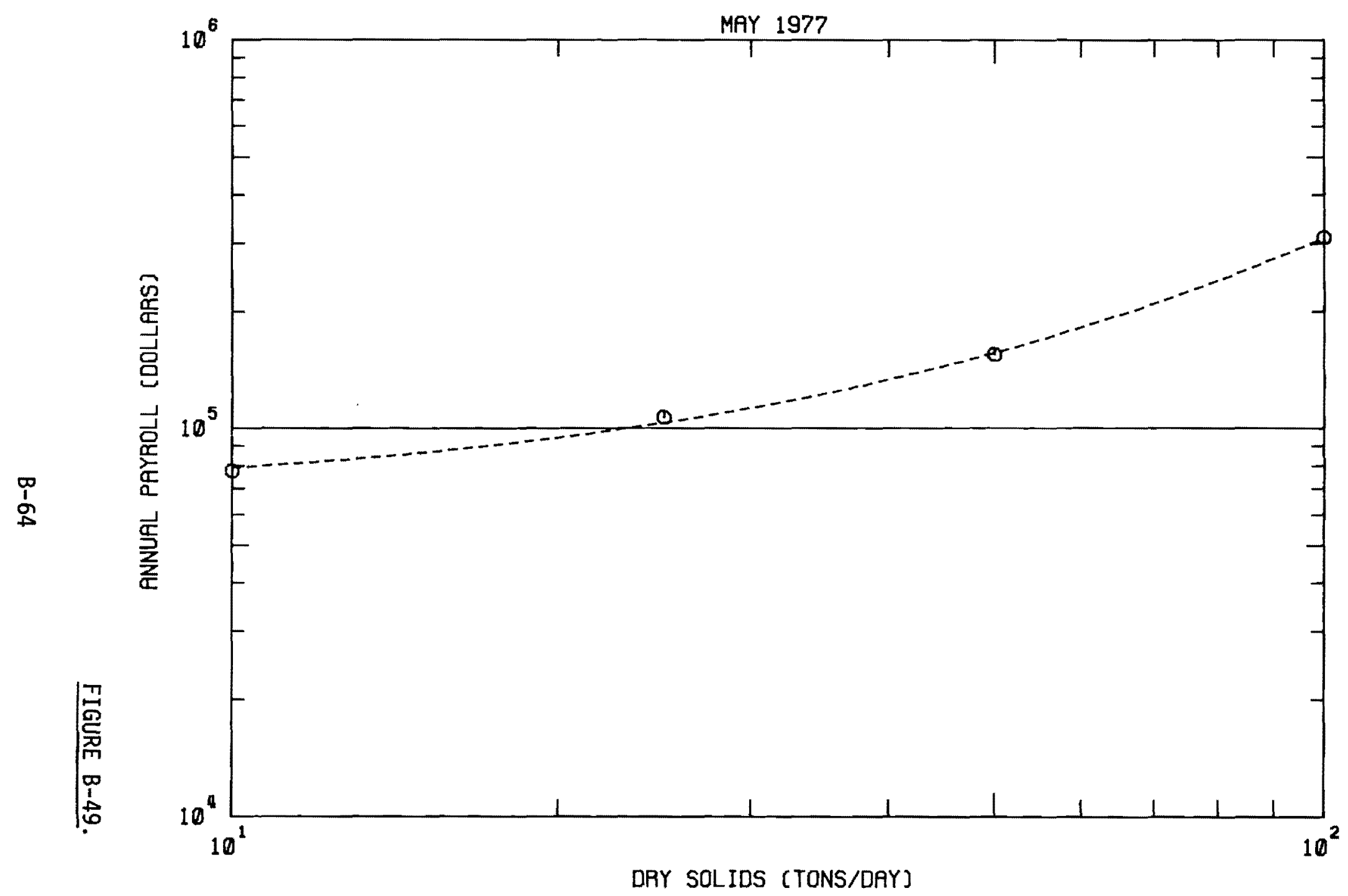

STATIC PILE COMPOSTING - LABOR REQUIREMENTS 


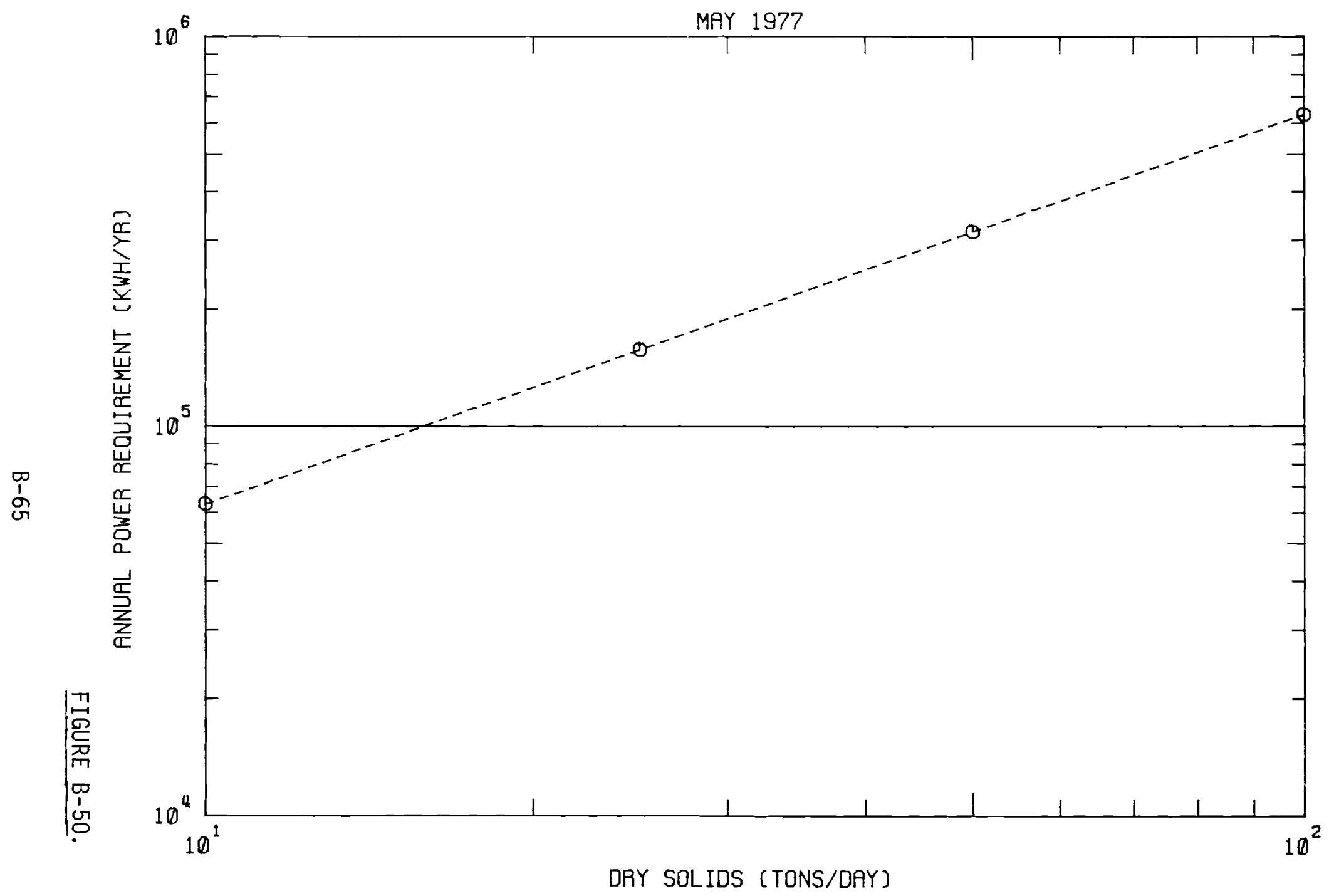

STATIC PILE COMPOSTING - POWER REQUIREMENTS 


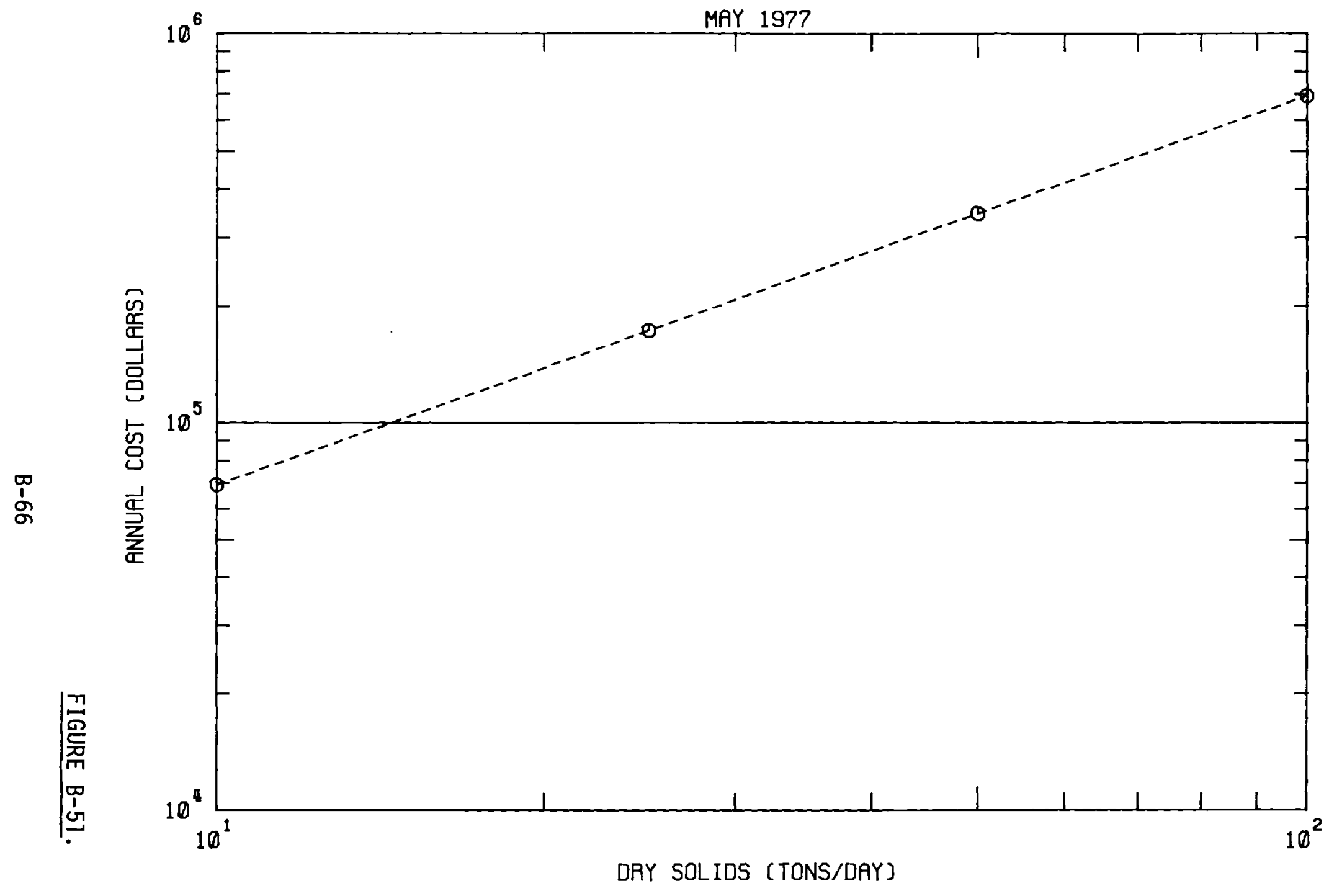

STATIC PILE COMPOSTING - MAINTENANCE MATERIAL AND SUPPLIES COSTS 


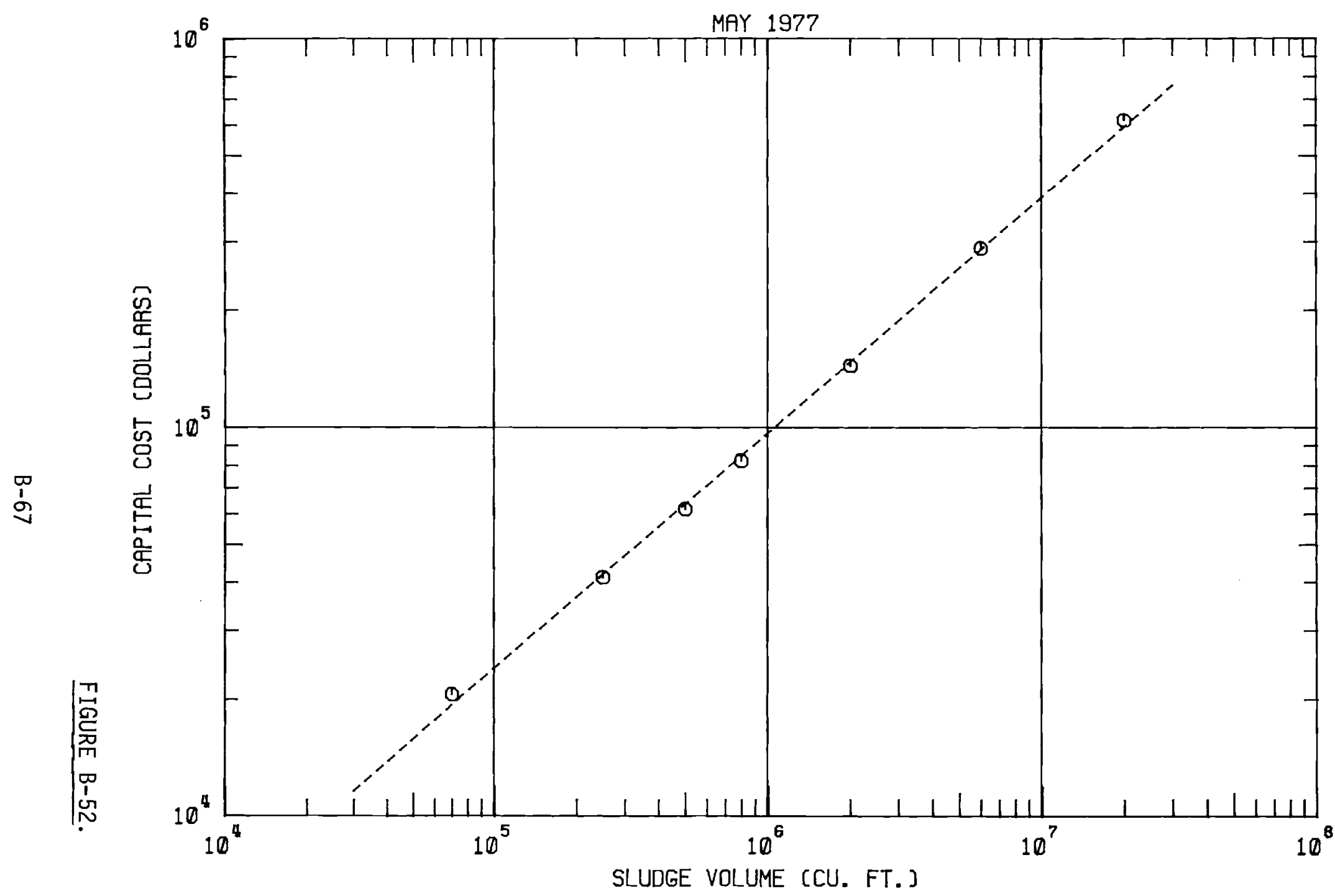

SLUDGE LAGOONS - CAPITAL COSTS 


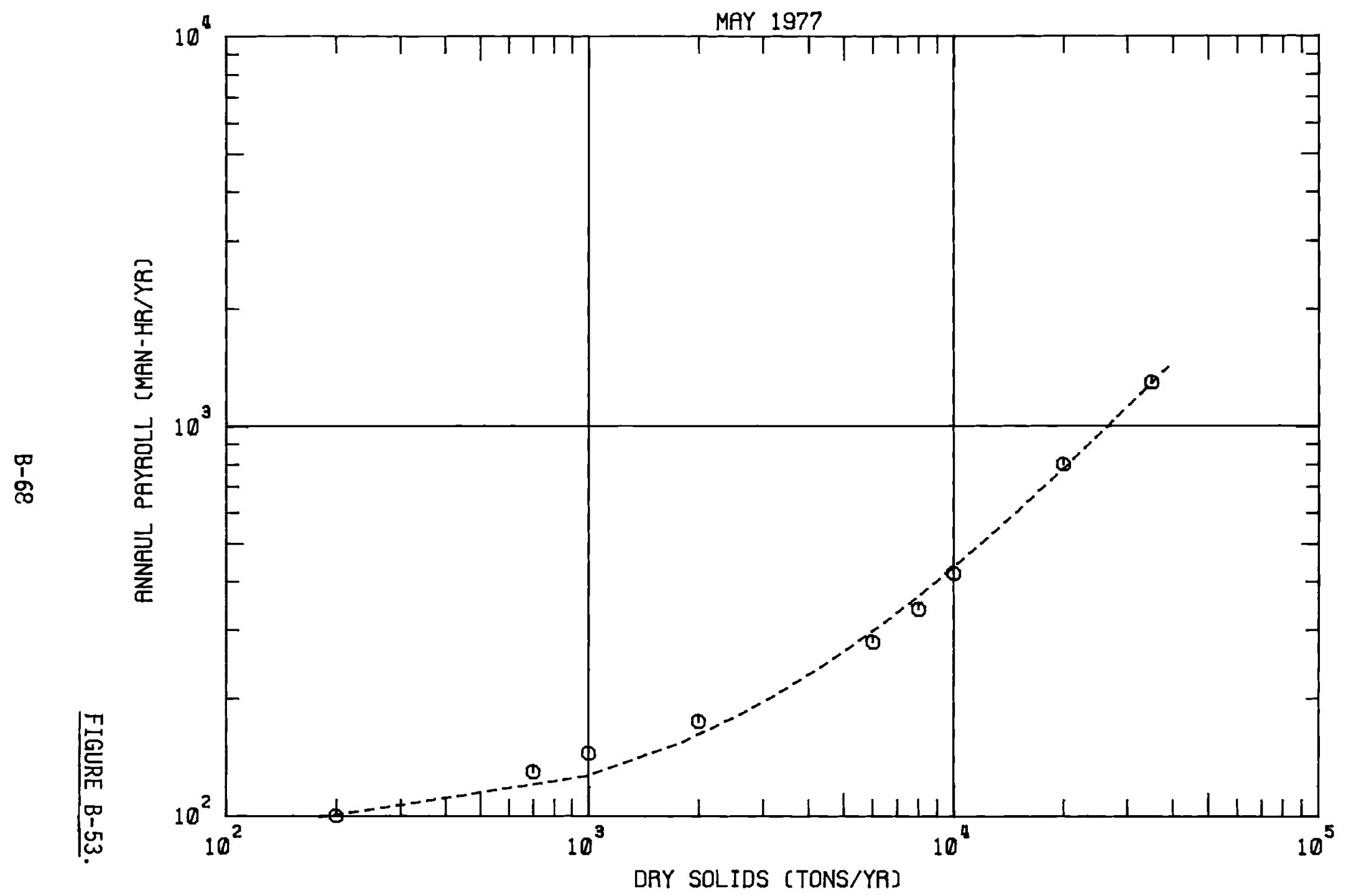

SLUDGE LAGOONS - LABOR REQUIREMENTS 


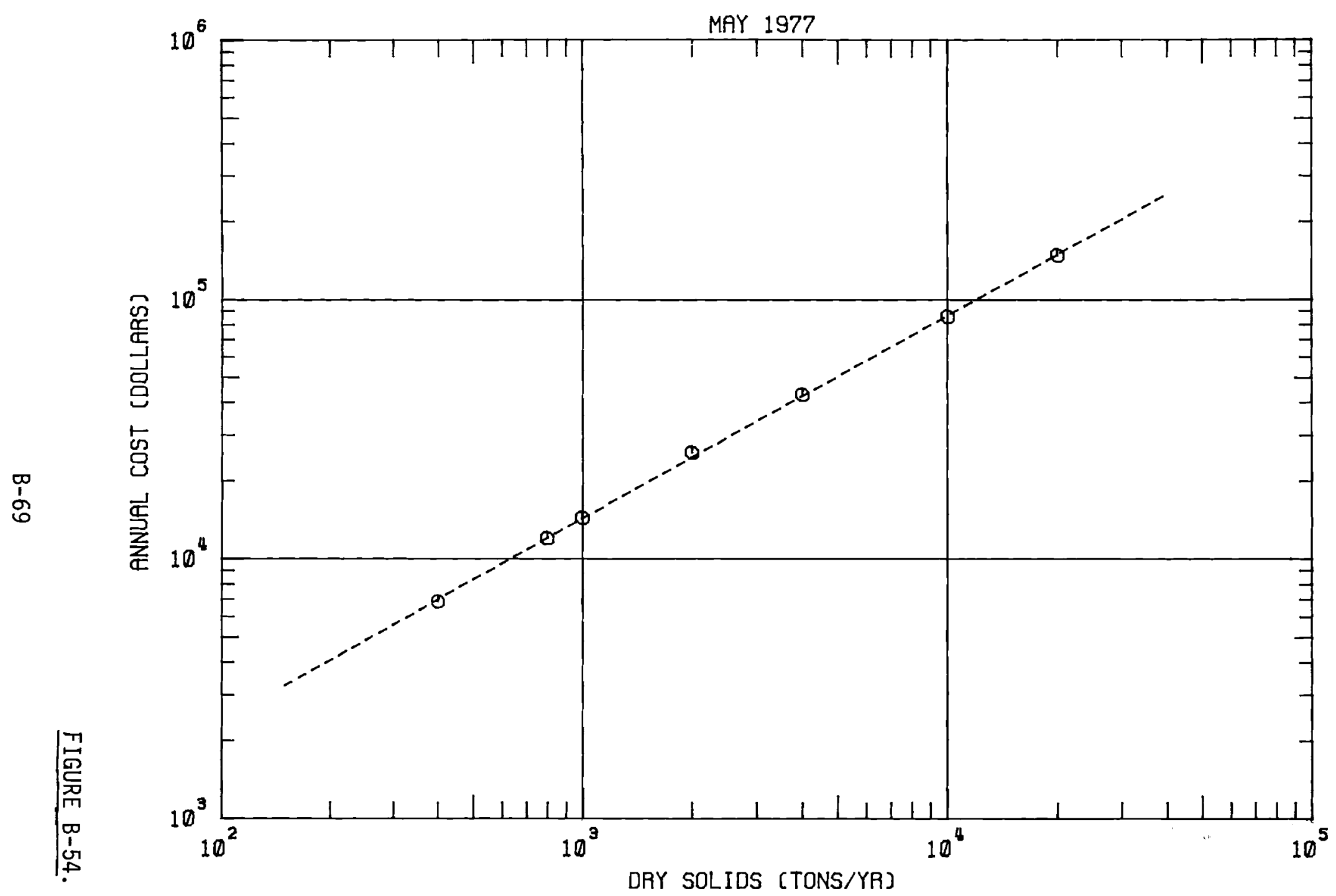

SLUDGE LAGOONS - MAINTENANCE MATERIAL AND SUPPLIES COSTS 


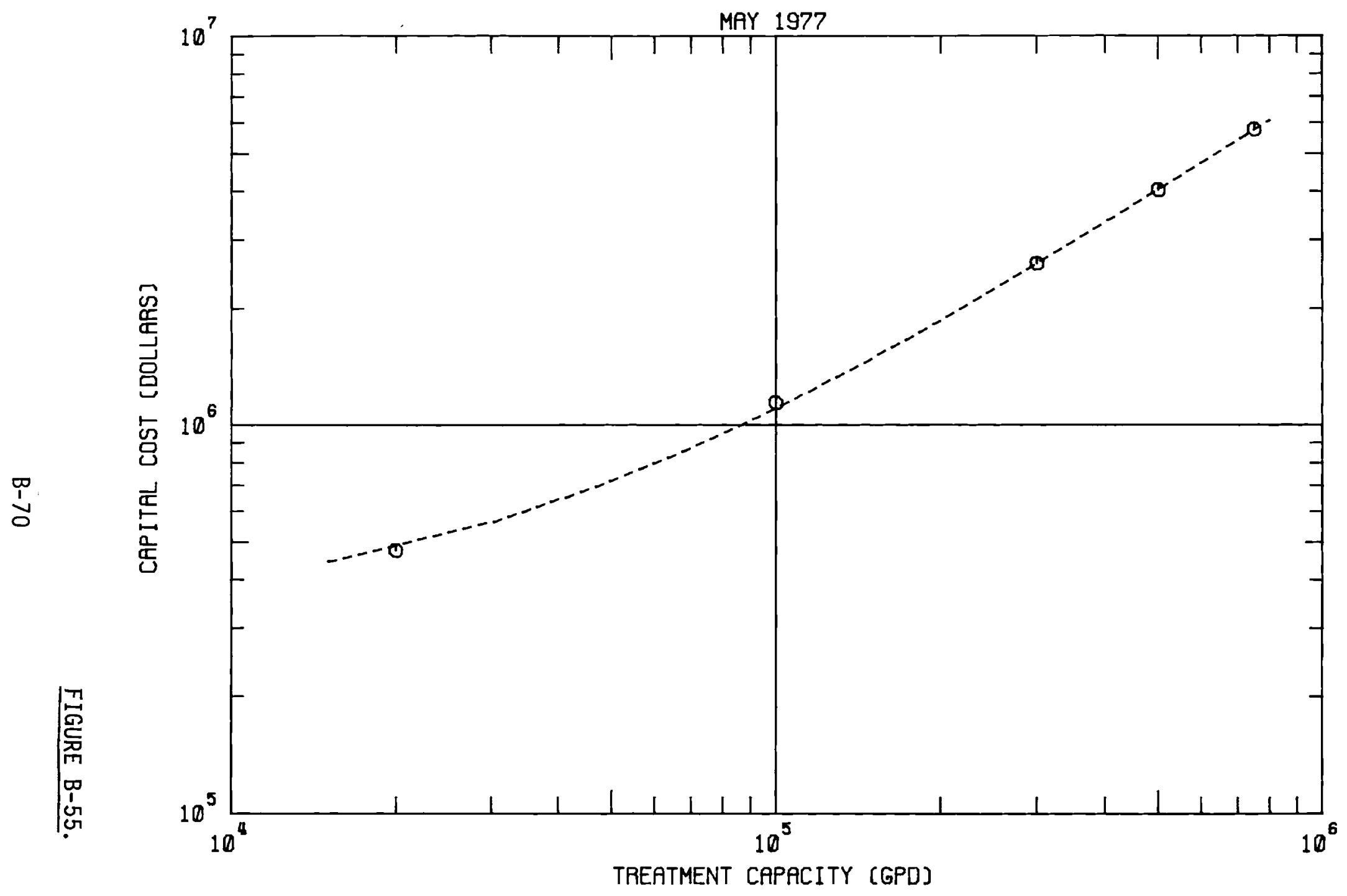

RADIATION TREATMENT OF LIOUID SLUDGE - CAPITAL COSTS 


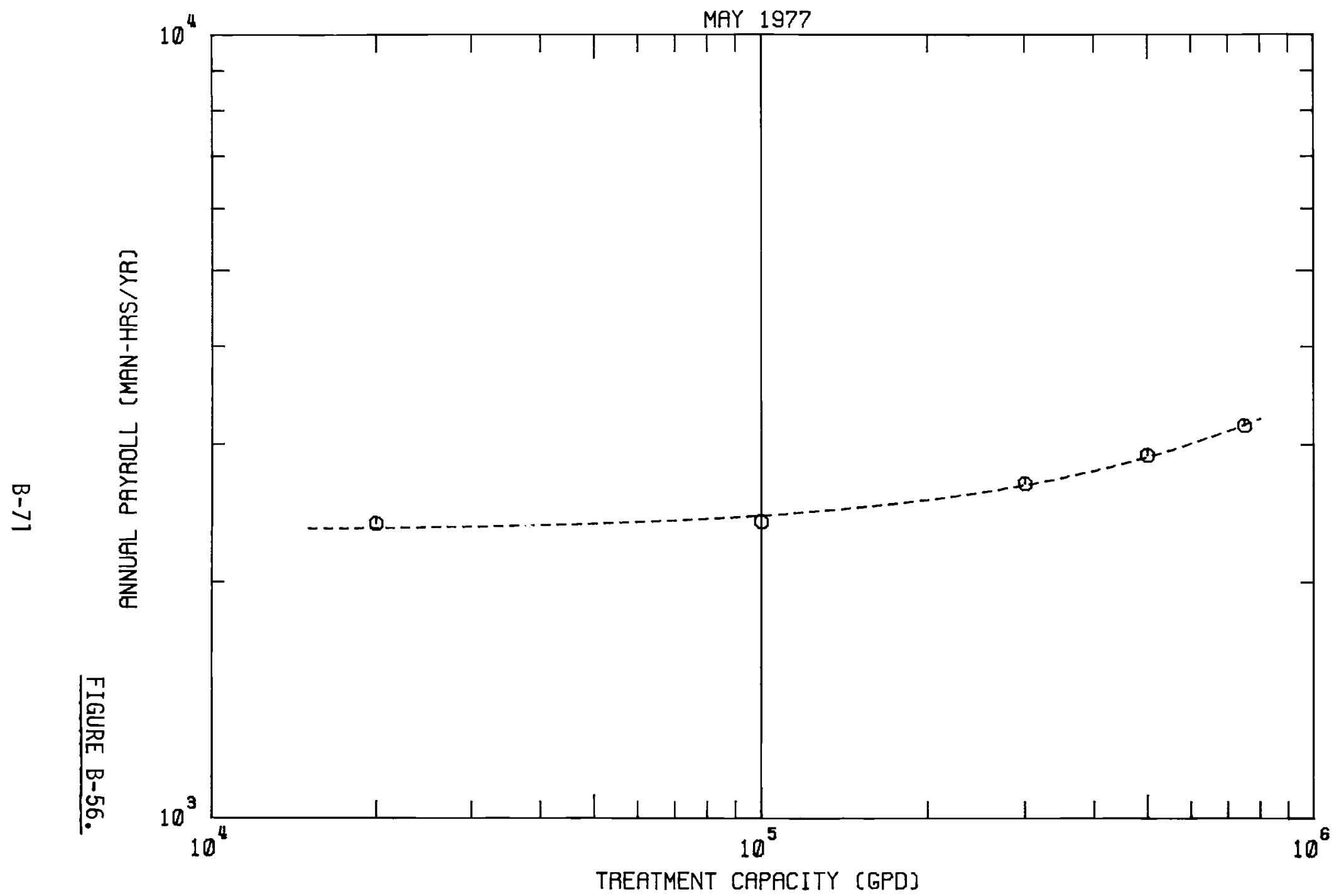

RADIATION TREATMENT OF LIOUID SLUDGE - LABOR REQUIREMENTS 


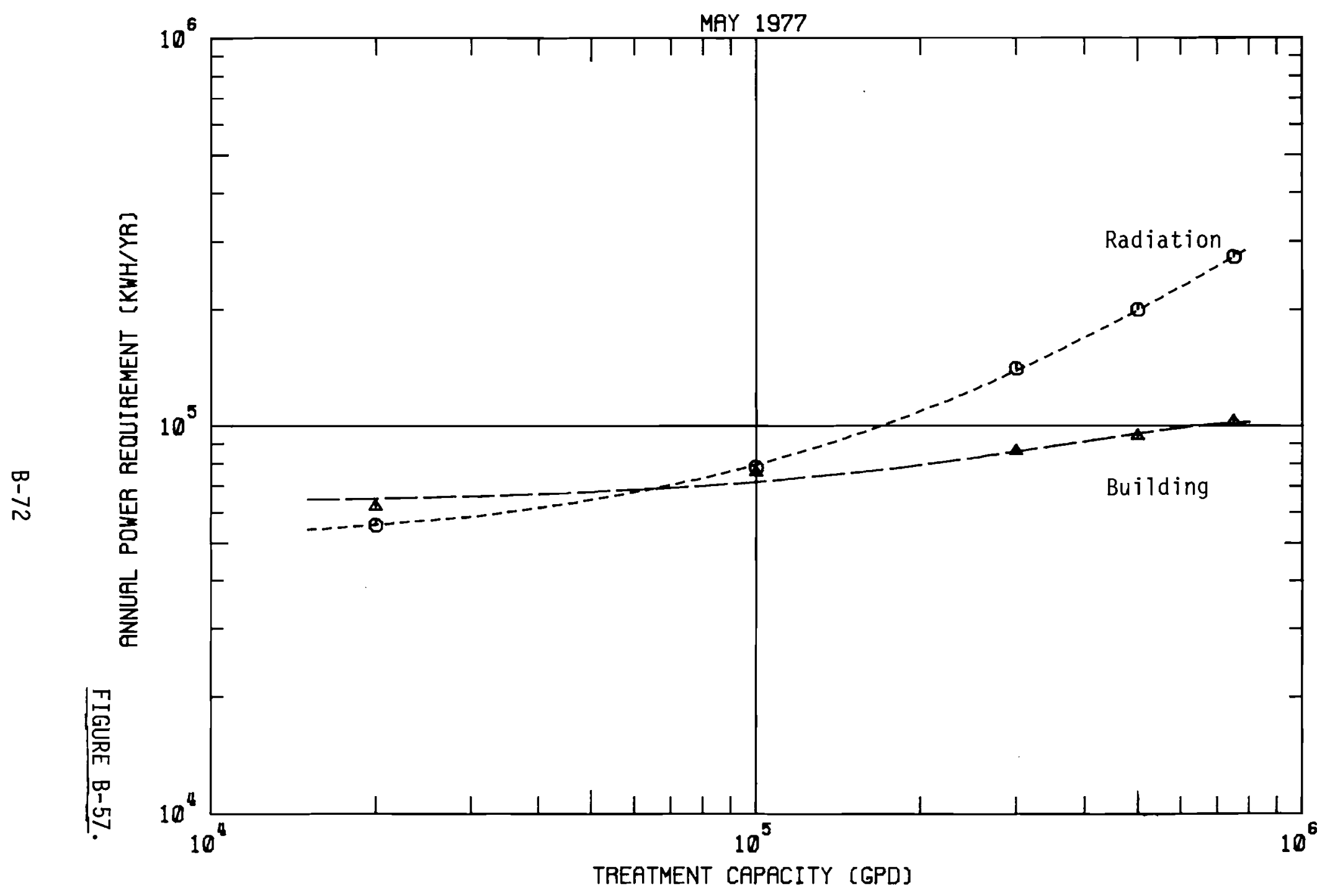

RADIATION TREATMENT OF LIQUID SLUDGE - POWER REQUIREMENTS 


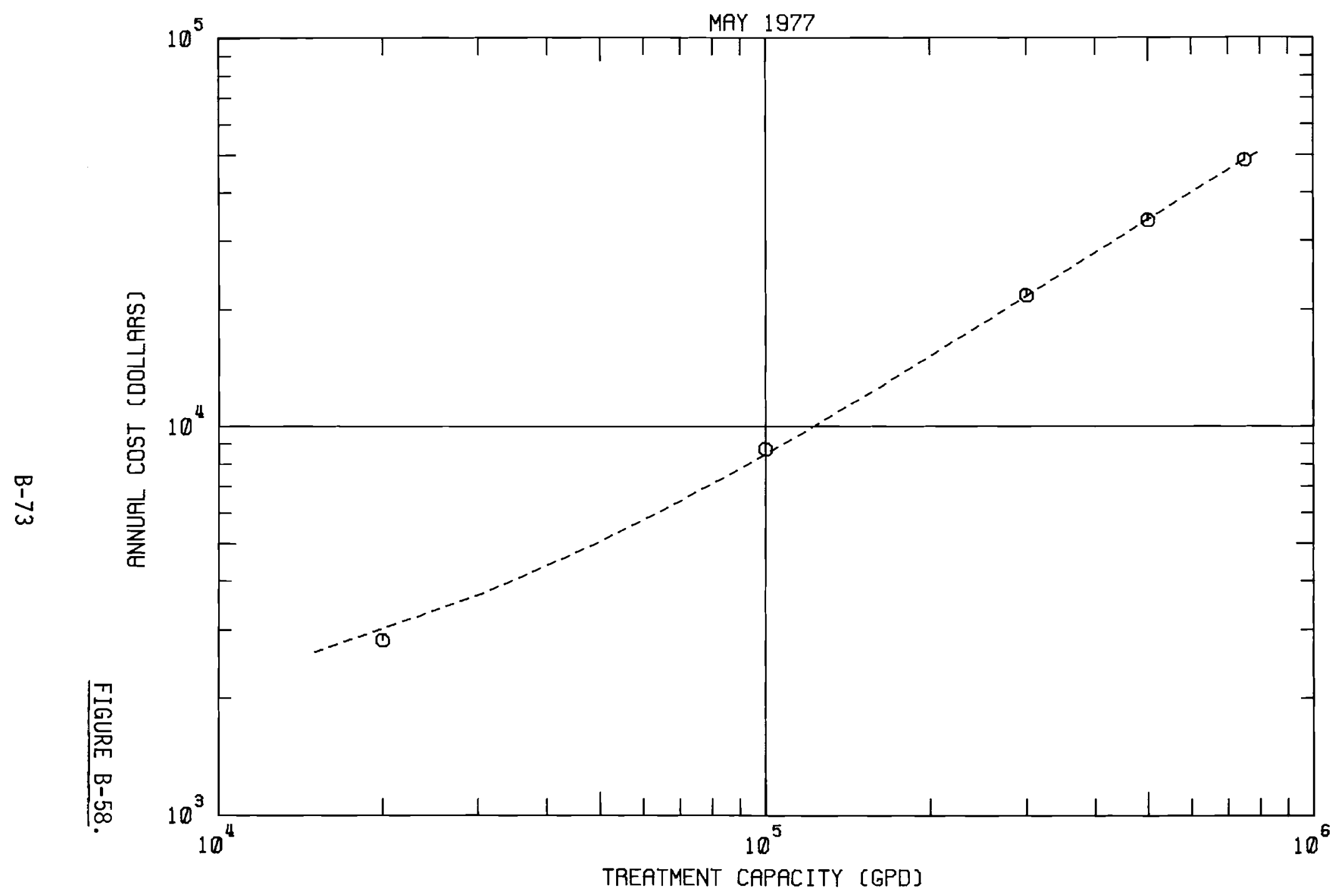

RADIATION TREATMENT OF LIOUID SLUDGE - MAINTENANCE MATERIAL AND SUPPLIES COSTS 
TABLE B-7. Cesium-137 costs for Irradiating Liquid Sludge (Source: Sandia Laboratories, Albuquerque, New Mexico)

\begin{tabular}{|c|c|c|}
\hline \multirow{2}{*}{$\begin{array}{l}\text { Treatment Capacity } \\
\text { (gpd) }\end{array}$} & \multicolumn{2}{|c|}{$\begin{array}{l}\text { Cost at } 0 \% \text { Interest } \\
\text { (\$/1000 gal Sludge) }\end{array}$} \\
\hline & Radiation & Thermoradiation \\
\hline 20,000 & 2.10 & 0.80 \\
\hline 100,000 & 2.00 & 0.60 \\
\hline 300,000 & 2.00 & 0.60 \\
\hline 500,000 & 2.00 & 0.60 \\
\hline 750,000 & 2.00 & 0.60 \\
\hline
\end{tabular}




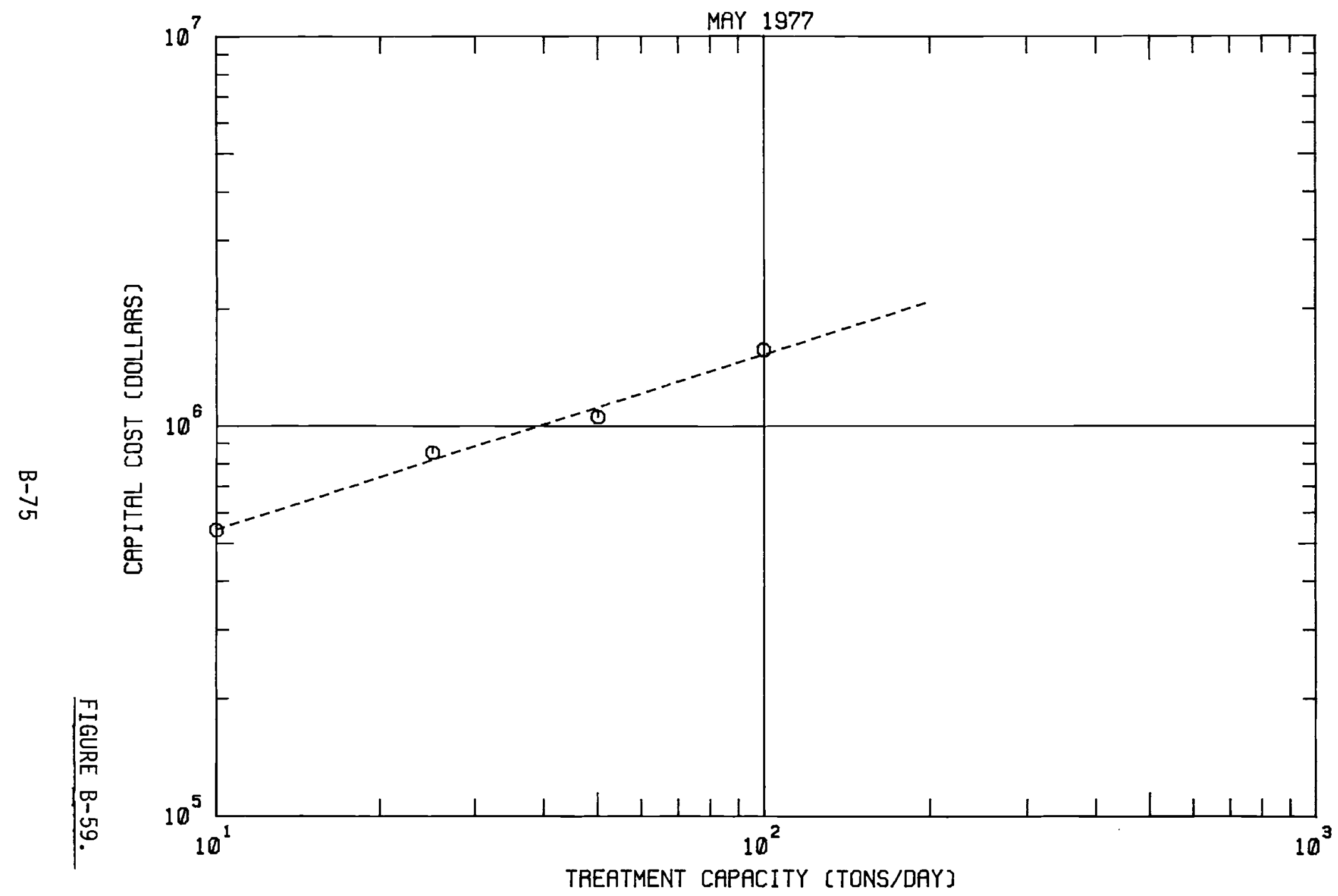

RADIATION TREATMENT OF DEWATERED SLUDGE - CAPITAL COST 


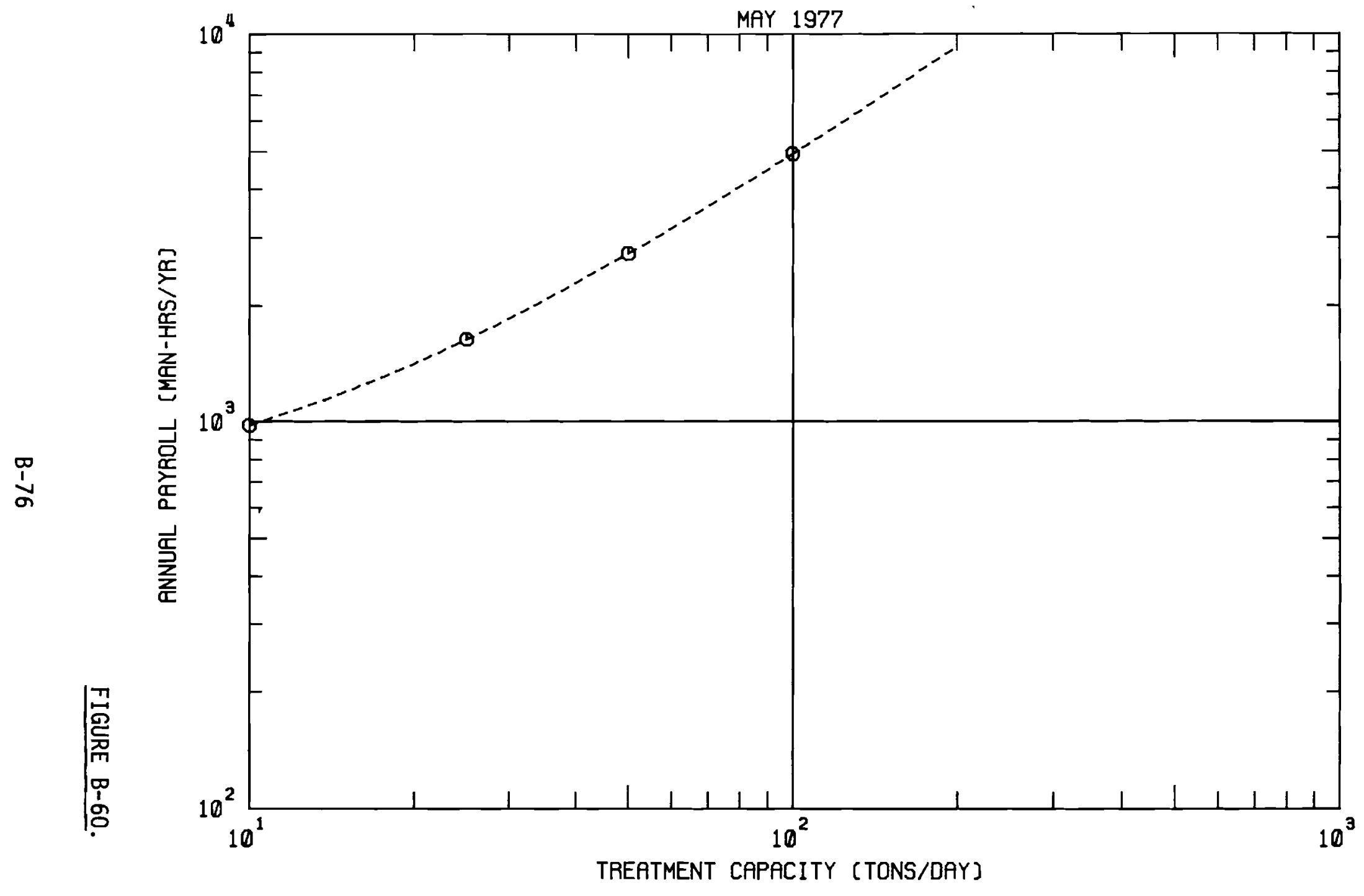

RADIATION TREATMENT OF DEWATERED SLUDGE - LABOR REOUIREMENTS 


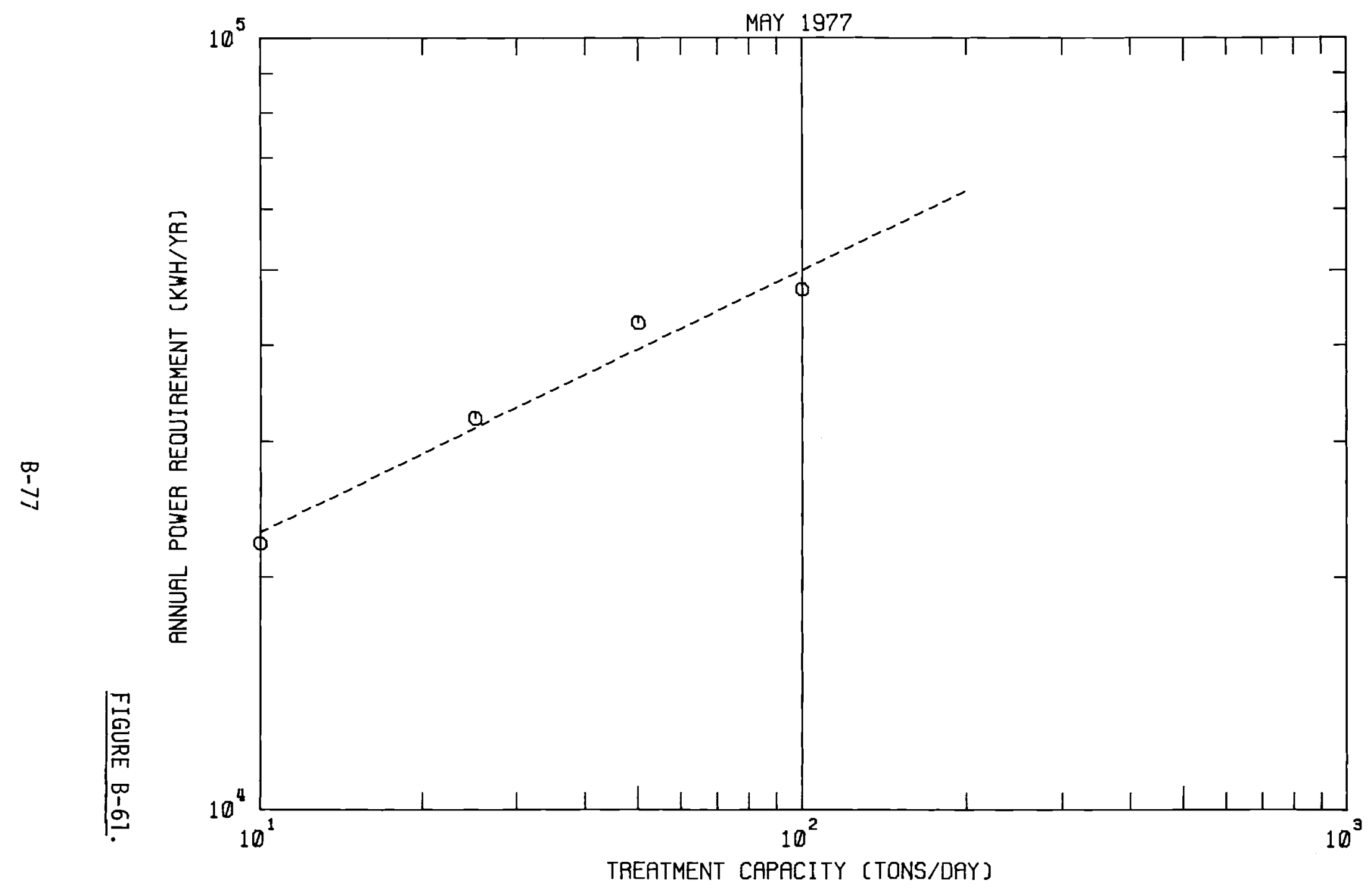

RADIATION TREATMENT OF DEWRTERED SLUDGE - POWER REQUIREMENTS 


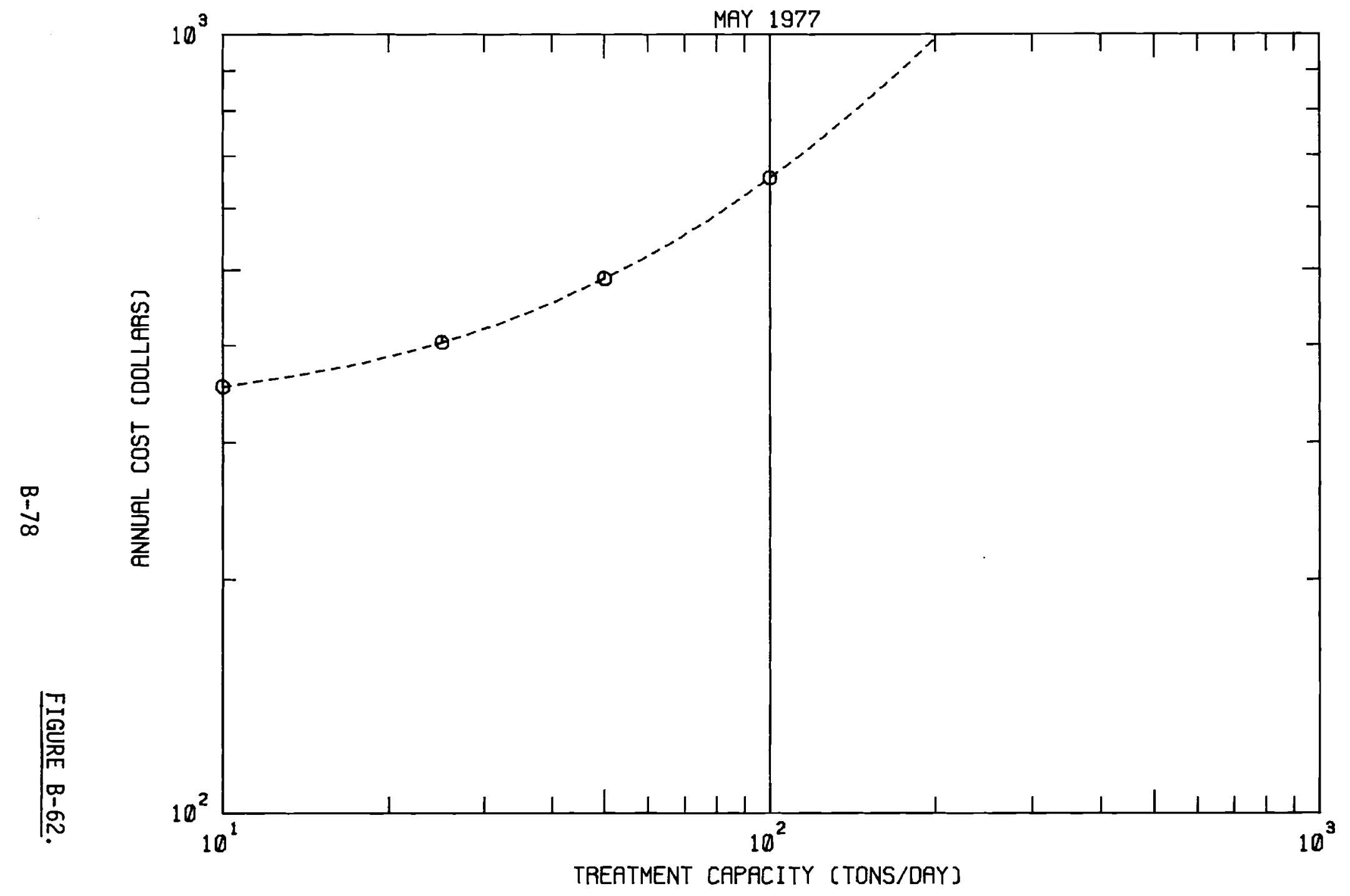

RADIATION TREATMENT OF DEWATERED SLUDGE MAINTENANCE MATERIALS AND SUPPLIES COST 
TABLE B-8. Cesium-137 costs for Irradiating Dry Sludge (Source: Sandia Laboratories, Albuquerque, New Mexico)

$\begin{array}{cc}\begin{array}{c}\text { Treatment Capacity } \\ \text { (tons/day) }\end{array} & \begin{array}{c}\text { Cost at } 0 \% \text { Interest } \\ \$ / \text { Ton of Sludge }\end{array} \\ 10 & 1.55 \\ 25 & 1.30 \\ 50 & 1.22 \\ 100 & 1.22\end{array}$




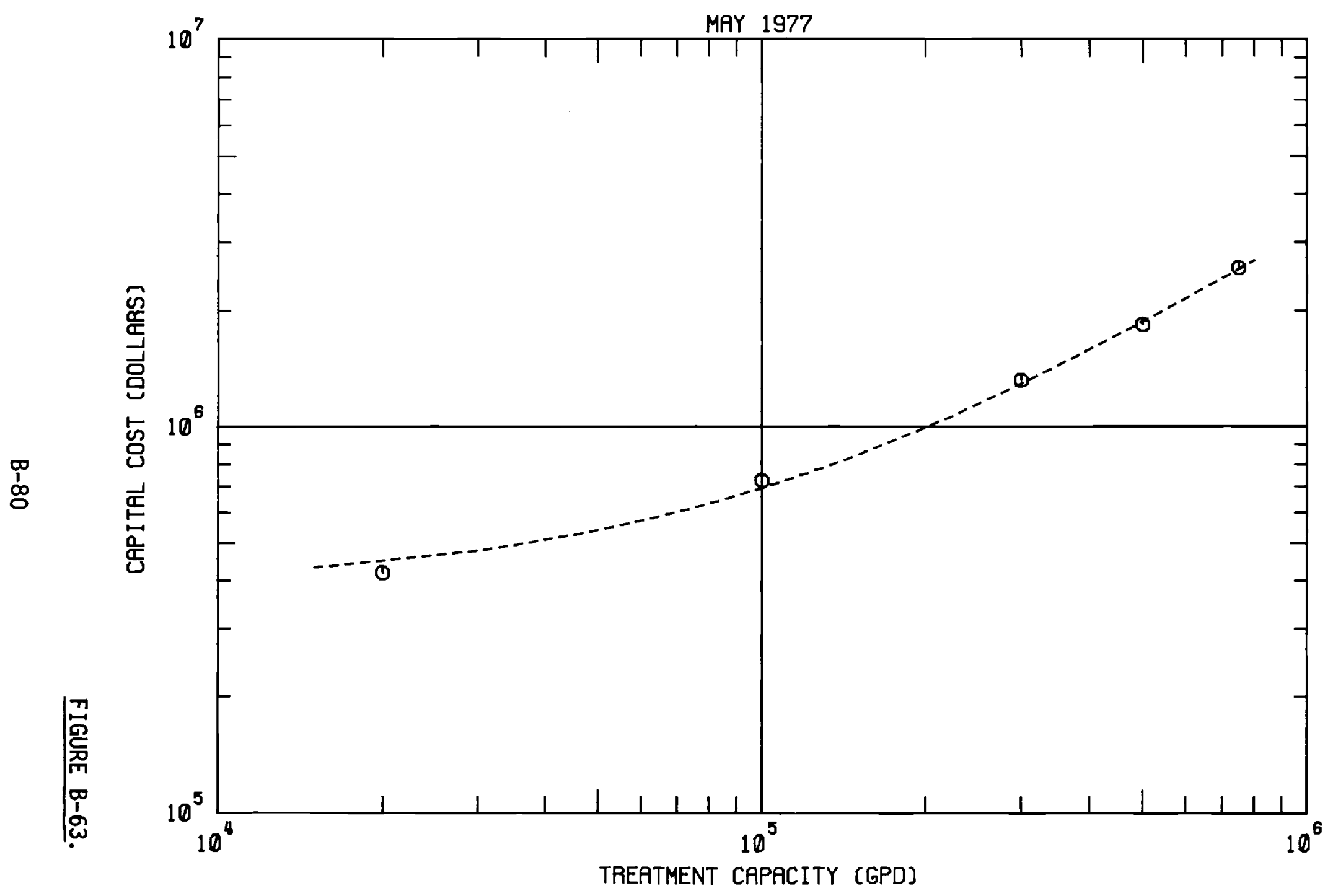

THERMORADIATION OF LIOUID SLUDGE - CAPITAL COSTS 


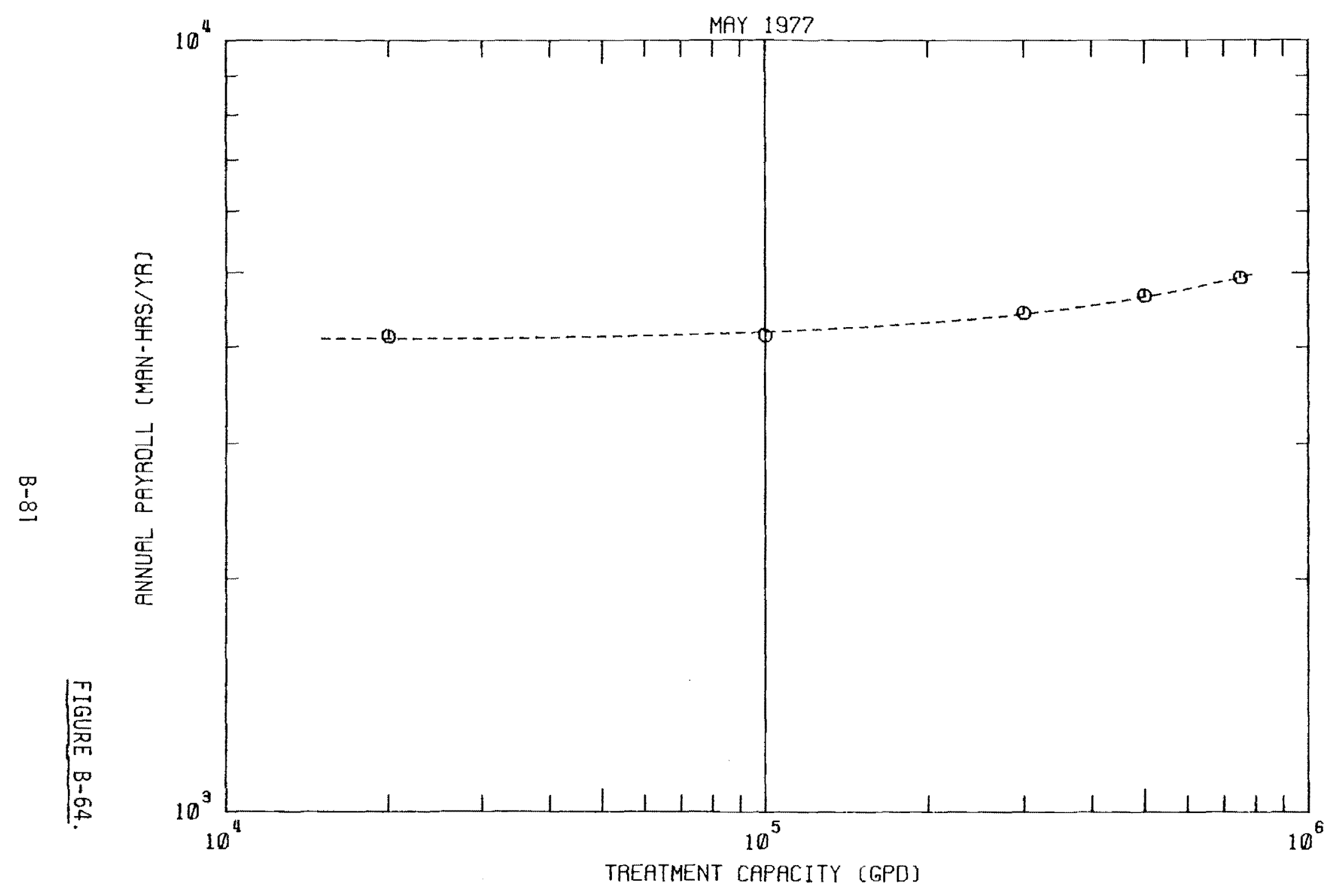

THERMORADIATION OF LIOUID SLUDGE - LABOR REQUIREMENTS 


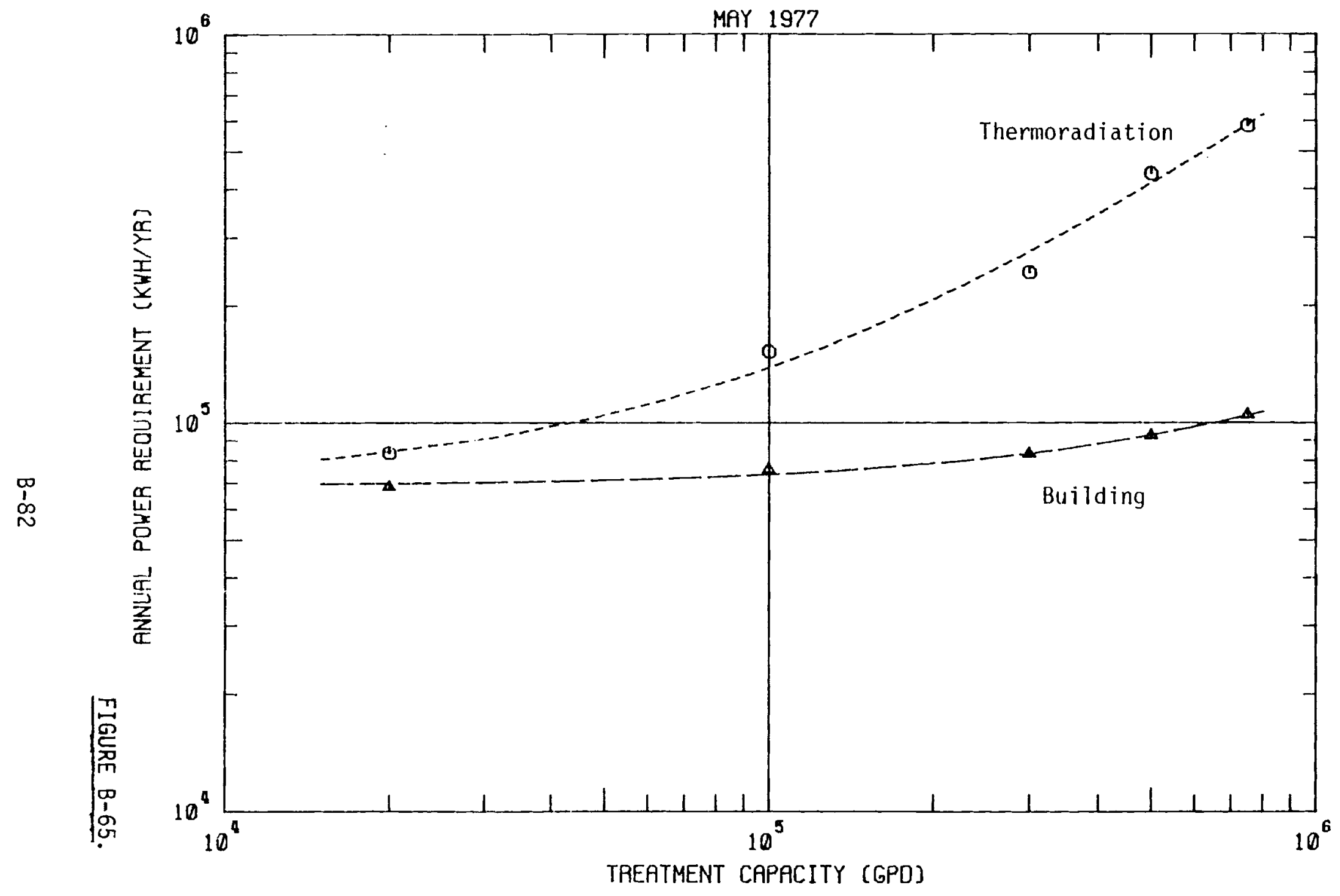

THERMORADIATION OF LIOUID SLUDGE - POWER REQUIREMENTS 


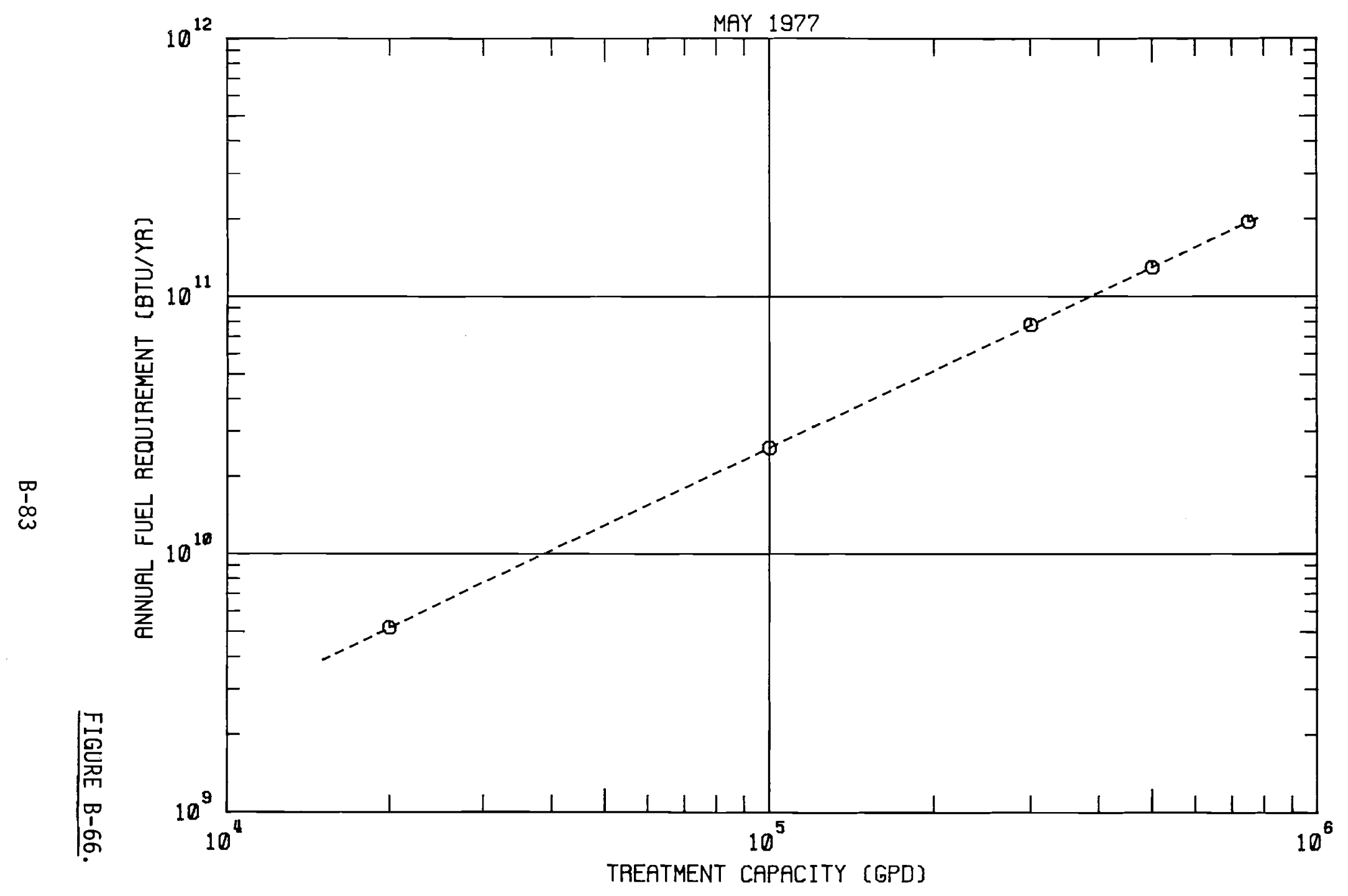

THERMORADIATION OF LIQUID SLUDGE - FUEL REOUIREMENTS 


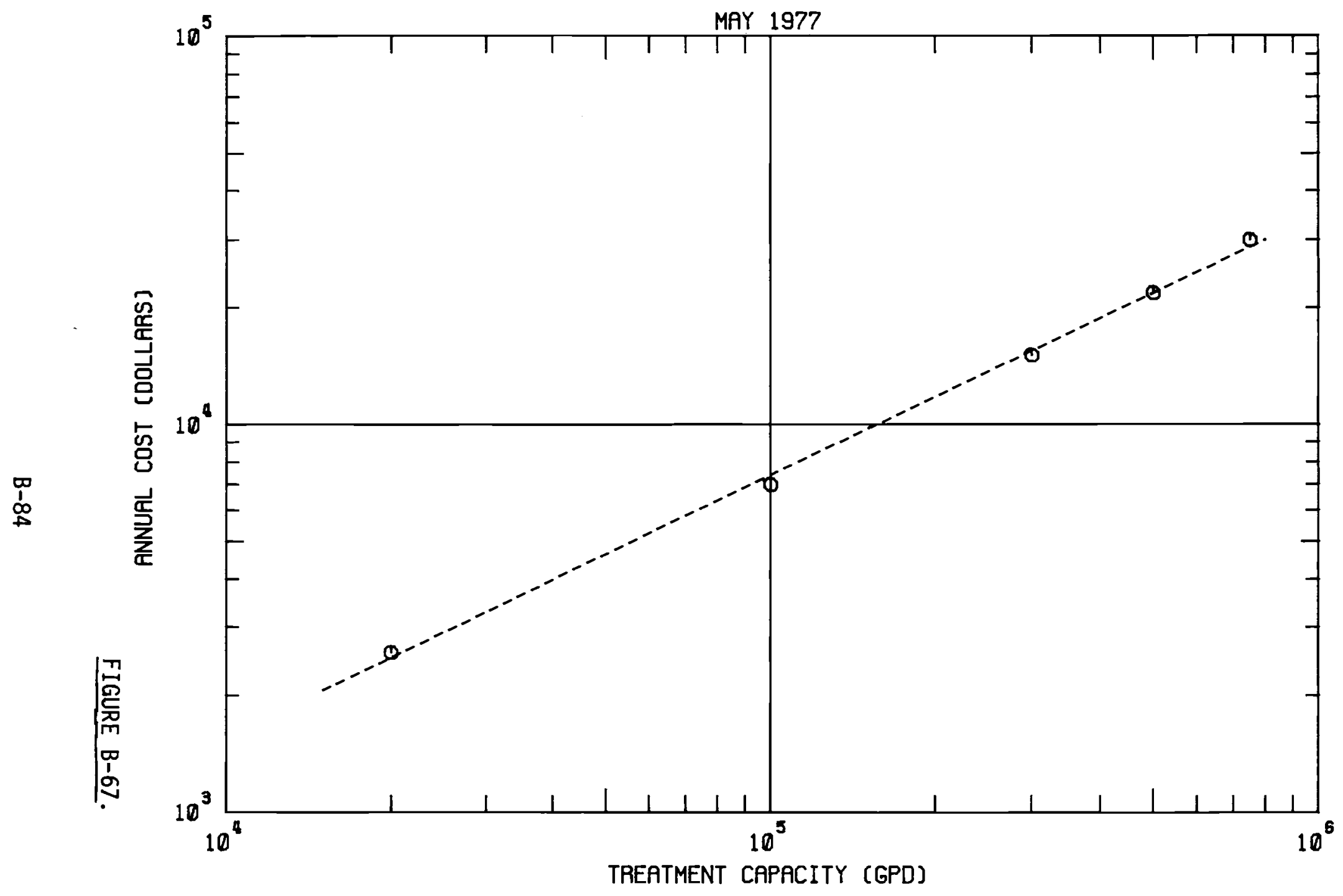

THERMORADIATION OF LIOUID SLUDGE - MAINTENANCE MATERIAL AND SUPPLIES COSTS 


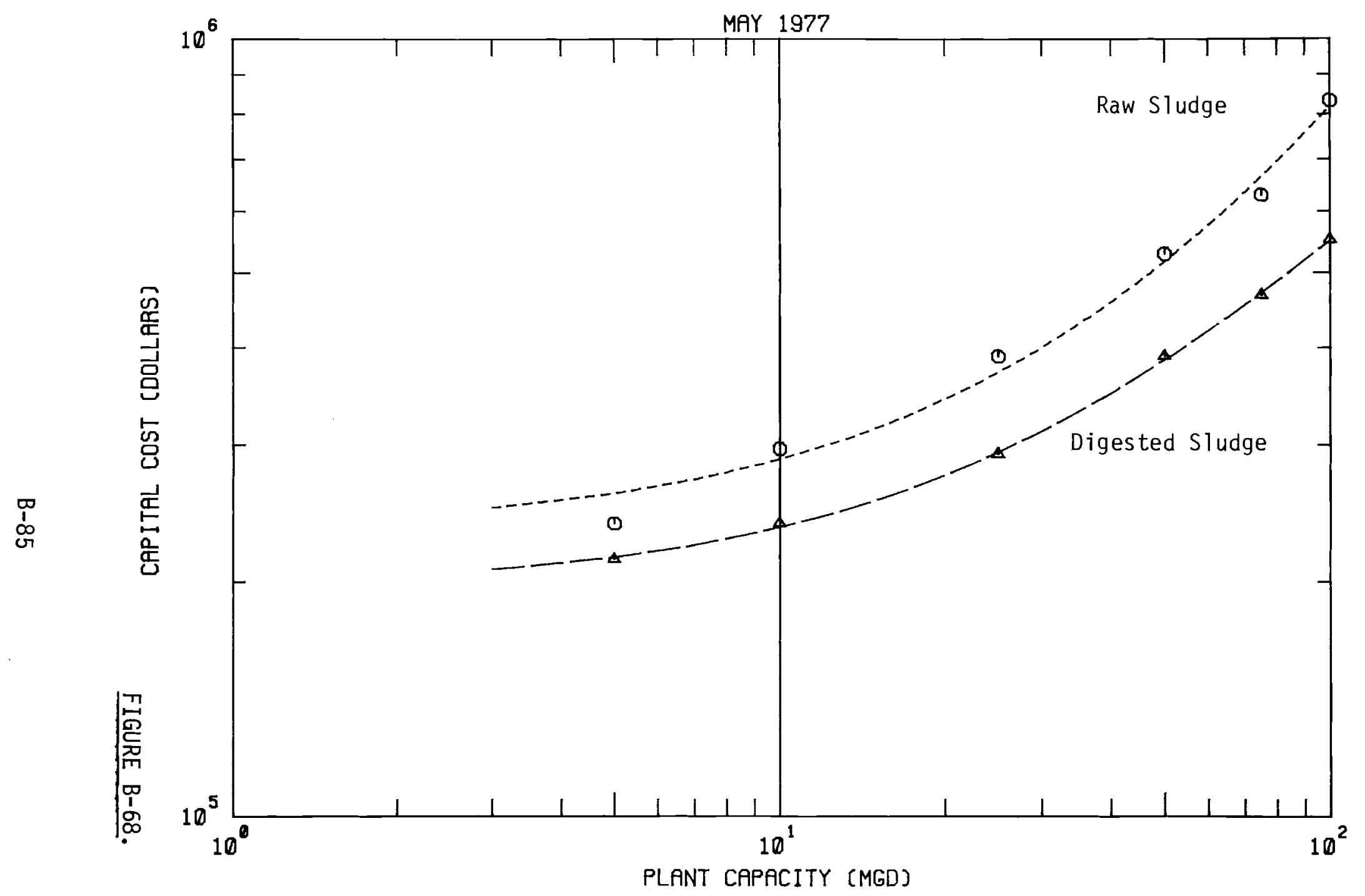

PASTEURIZATION OF LIOUID SLUDGE - CAPITAL COST 


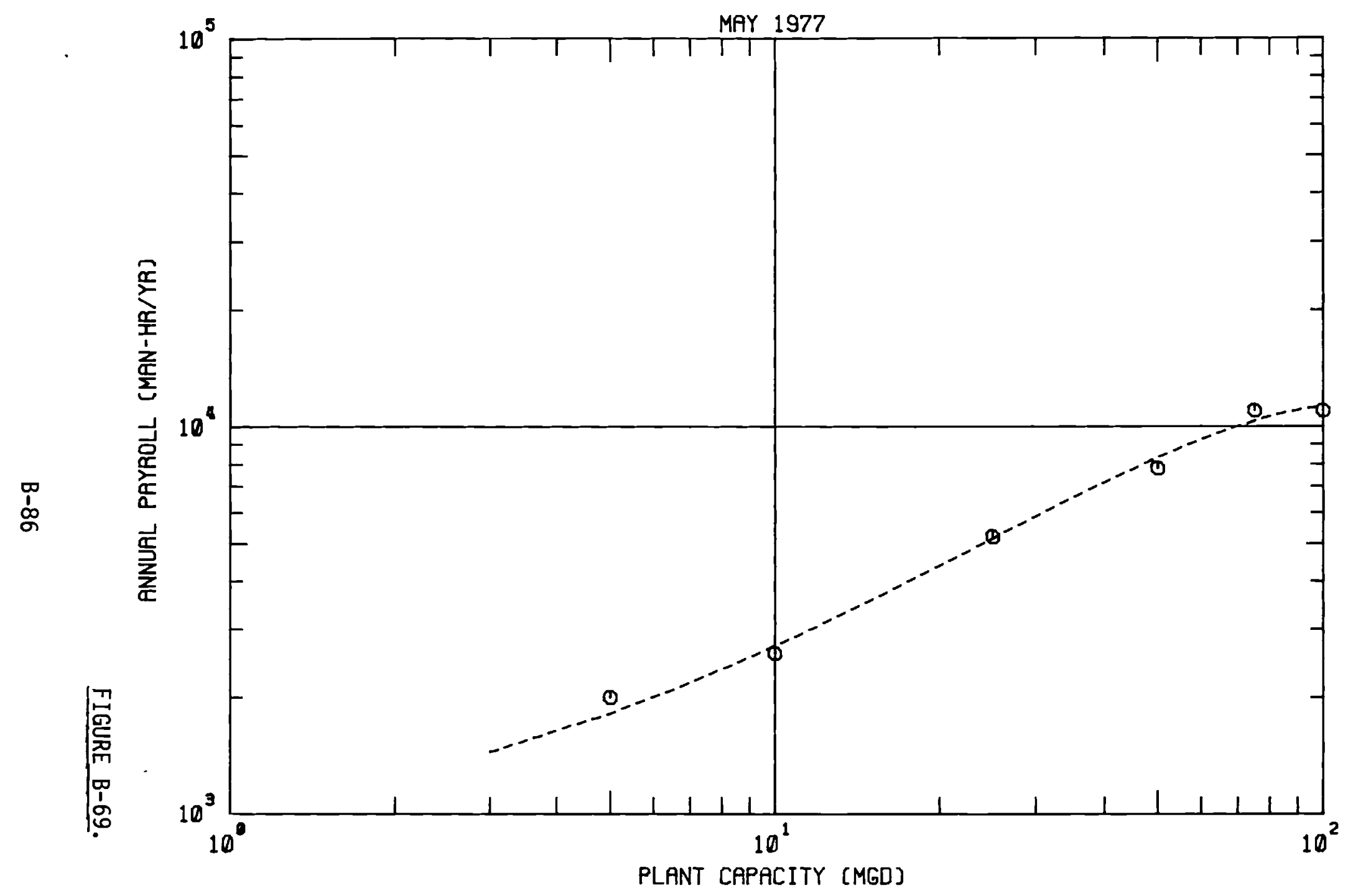

PASTEURIZATION OF LIOUID SLUDGE - LABOR REQUIREMENTS 


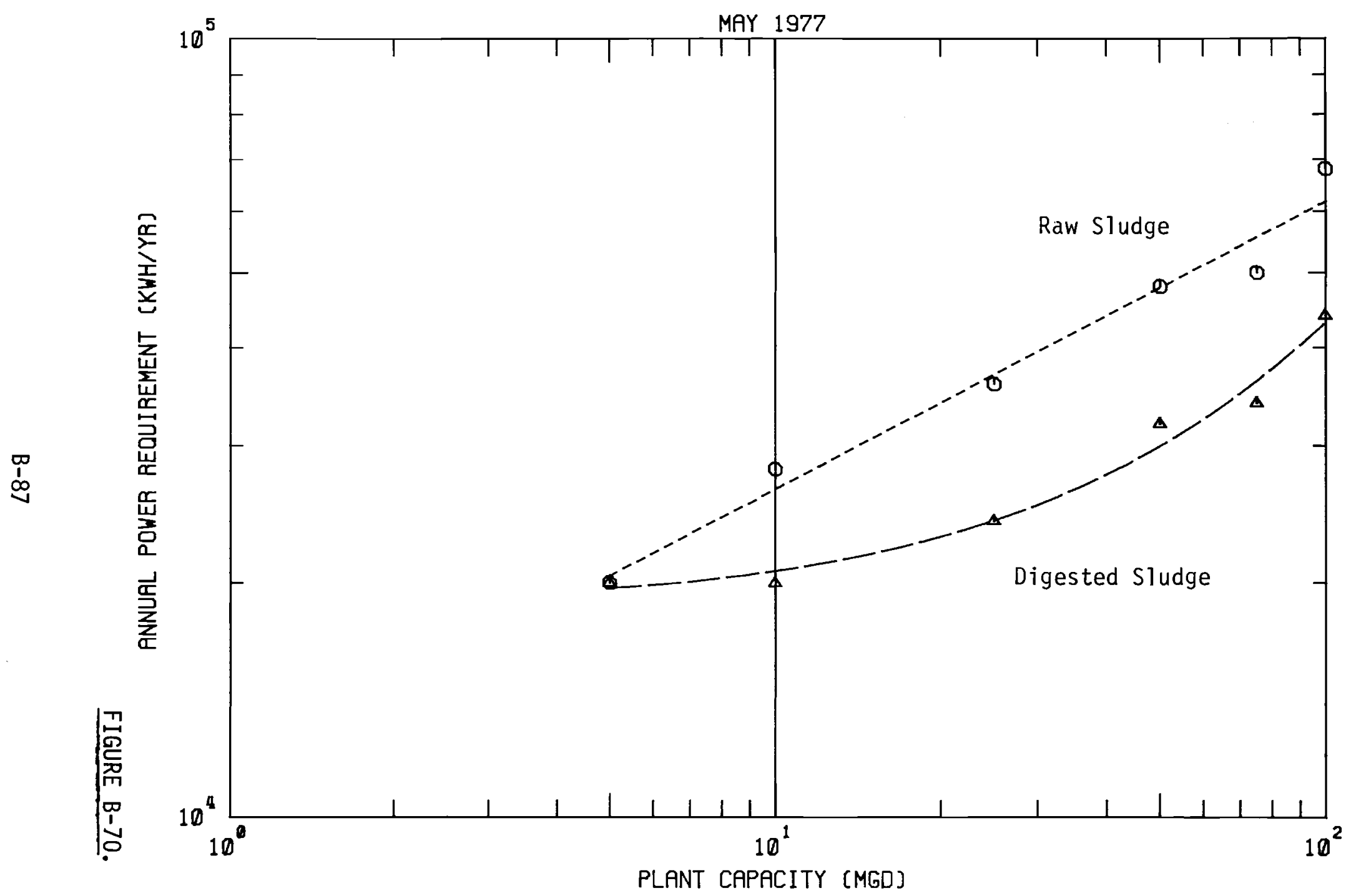

PASTEURIZATION OF LIOUID SLUDGE - POWER REQUIREMENTS 


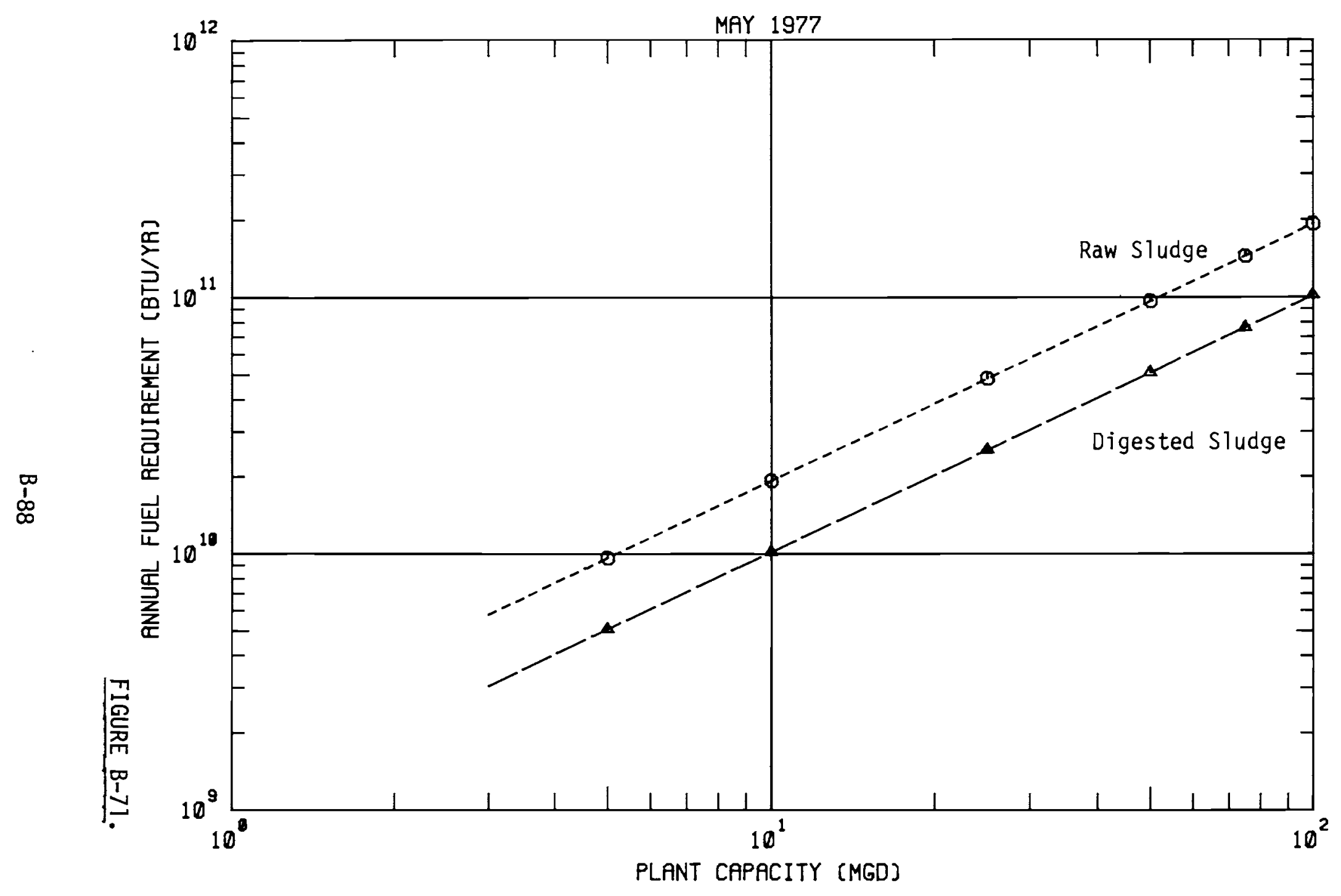

PASTEURIZATION OF LIQUID SLUDGE - FUEL REQUIREMENTS 


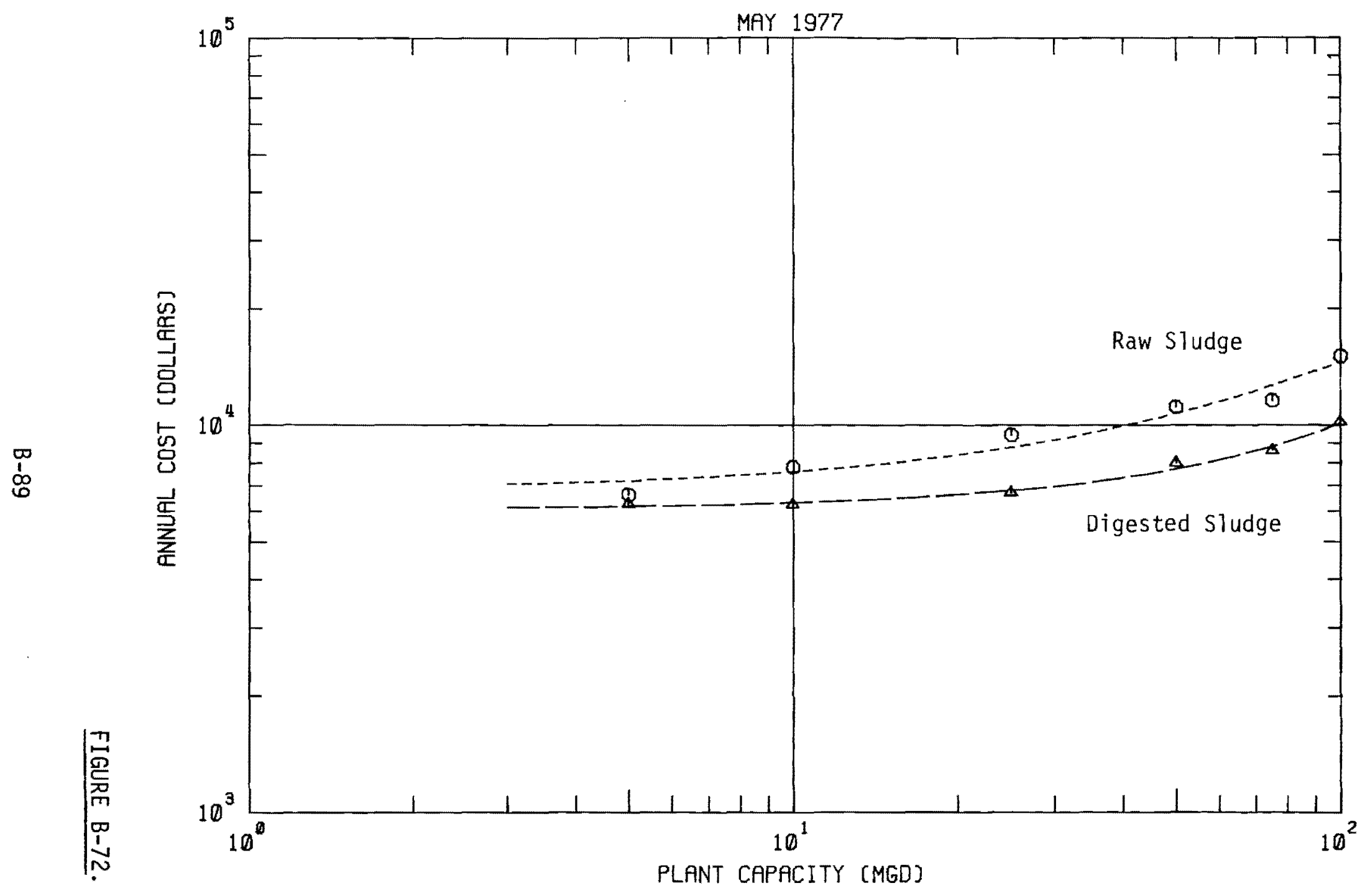

PASTEURIZATION OF LIQUID SLUDGE - MAINTENANCE MATERIAL AND SUPPLIES COSTS 
STRATEGY FOR CALCULATING COST OF TRANSPORTING SLUDGE BY TRUCK

(Based on Reference 8)

1. ( $\left.\frac{\text { Annual Sludge Volume }}{\text { Truck Capacity from Table B-9 }}\right) \times$ (Distance of one way haul) $\times$ (2)

= Miles Traveled Annually

2. (Miles traveled annually) $\times$ (MPG from Table B-9) $\times$ (fuel cost $\$ /$ gal)

$=$ Annual Fuel cost

3. $\left[\right.$ (Miles traveled annually) $\times\left(\begin{array}{l}\text { speed }- \text { herein assumed to be } \\ 25 \mathrm{mph} \text { first } 20 \mathrm{miles}, 35 \mathrm{mph} \\ \text { thereafter }\end{array}\right)+$

(Load time, usually 30 minutes) + (unload time, usually 15 minutes)] $x$

(allowance for driver time in excess of truck operating time, usually

$10 \%) \times$ (operators salary, includes benefits $\$ / M H)=$ Annual operator cost

4. (Miles traveled annually) $\times\left(\begin{array}{l}\text { operation cost } \\ \text { from Table B-9 }\end{array}\right) \times\left(\frac{\text { current WPI I tem 1412* }}{170.3}\right)$

$=$ Annual maintenance cost

5. (Annual Fuel Cost + Annual Operator Cost + Annual Maintenance Cost)

$\times\left(\begin{array}{l}\text { Overhead and Supervision } \\ \text { Factor, Usually } 1.25\end{array}\right)=$ Truck 0\&M Cost

6. $\left[\begin{array}{l}\text { No. of trucks required } \\ \text { from Figure B-73 }\end{array}\left(\begin{array}{l}\text { Capital cost per truck } \\ \text { from Table B-9 }\end{array}\right) \begin{array}{l}\text { Residual value, usually } \\ 15 \% \text { of new }\end{array}\right]$

$\times\left(\frac{\text { Current WPI Item 141102* }}{150.2}\right) \times\left(\begin{array}{l}\text { Amortization factor } \\ \text { usually } 0.20980\end{array}\right)+($ Residual value)

$x$ (Interest Rate usually .07) $=$ Truck Amortization

* U.S. Department of Labor Wholesale Price Indexes (WPI) are published monthly in "Wholesale Prices and Price Indexes," or may be requested by phoning 1-800-227-0803. 
7. $\left(\begin{array}{l}\text { Facilities Capital Cost } \\ \text { from Figures B-74 or } \\ B-75\end{array}\right) \times\left(\begin{array}{l}\text { Current ENR Construction* } \\ \frac{\text { Cost Index }}{2515}\end{array}\right)$

$\times\left(\begin{array}{l}\text { Amortization factor } \\ \text { usually } 0.09439\end{array}\right)=$ Facilities Amortization

8. $\left(\begin{array}{l}\text { Electrical Energy } \\ \text { kWh/yr from Figures } \\ \mathrm{B}-76 \text { and } \mathrm{B}-77\end{array}\right) \times($ Current Rate $\$ / \mathrm{kWh})=$ Power Cost

9. $\left(\begin{array}{l}\text { Maintenance Man-hours } \\ \text { from Figure } B-78\end{array}\right) \times\left(\begin{array}{l}\text { Current Rate } \$ / M H \\ \text { includes Fringes }\end{array}\right)=$ Labor Cost

10. ( $\left.\begin{array}{l}\text { Maintenance Supplies } \\ \text { from Figure B-79 }\end{array}\right) \times\left(\frac{\text { Current WPI Item 114** }}{174.8}\right)=\begin{aligned} & \text { Maintenance Supplies } \\ & \text { Cost }\end{aligned}$

11. $[($ Power Cost $)+($ Labor Cost $)+($ Maintenance Supplies Cost $)]$

$x$ (Overhead and Supervision Factor, usually 1.25$)=$ Facilities 0\&M Cost

12. (Truck 0\&M Cost) + (Truck Amortization) + (Facilities Amortization) +

(Facilities 0\&M Cost) = Total Annual Cost

13. a) If Dewatered Sludge:

$\frac{\left(\text { Total Annual Cost) } \frac{20001 \mathrm{~b}}{\text { ton }}\right.}{\left(\text { Annual } \mathrm{yd}^{3}\right)\left(\frac{27 \mathrm{ft}^{3}}{\mathrm{yd}}\right)\left(\frac{551 \mathrm{~b}}{\mathrm{ft}^{3}}\right)\left(\frac{\% \text { solids }}{100}\right)}=\$ /$ ton dry solids

b) If Liquid Sludge:

$\frac{\text { (Total Annual Cost) } \frac{20001 \mathrm{~b}}{\text { ton }}}{\text { (Annual gallons) }\left(\frac{8.331 \mathrm{~b}}{\text { gal }}\right)\left(\frac{\% \text { solids }}{100}\right)}=\$ /$ ton dry solids

* Published weekly in Engineering News Record, McGraw-Hi11, Inc., Highstown, NJ, 08520.

** U.S. Department of Labor Wholesale Price Indexes (WPI) are published monthly in "Wholesale Prices and Price Indexes," or may be requested by phoning 1-800-227-0803. 
TABLE B-9. Truck Data (from Reference 16)

\begin{tabular}{|c|c|c|c|c|c|}
\hline $\begin{array}{c}\text { Type } \\
\text { Sludge }\end{array}$ & Capacity & Type Truck & $\begin{array}{c}\text { Capital } \\
\text { Cost, } \$(t)\end{array}$ & $\begin{array}{l}\text { Fuel } \\
\text { Use, } \\
\text { MPG }\end{array}$ & $\begin{array}{c}\text { Operation } \\
\text { Cost, }(*)(\neq) \\
\$ / \text { mile } \\
\end{array}$ \\
\hline Liquid & $1200 \mathrm{ga} 1$ & 2 axle tanker & 25,000 & 4.5 & 0.20 \\
\hline Liquid & $2500 \mathrm{gal}$ & 3 axle tanker & 42,000 & 4.5 & 0.25 \\
\hline Liquid & $5500 \mathrm{gal}$ & Semi, tanker & 55,000 & 3.5 & 0.30 \\
\hline Dewatered & $10 y d^{3}$ & 2 axle dump & 25,000 & 4.5 & 0.20 \\
\hline Dewatered & $15 \mathrm{yd}^{3}$ & 3 axle dump & 42,000 & 4.5 & 0.25 \\
\hline Dewatered & $30 y d^{3}$ & Semi, dump & 50,000 & 3.5 & 0.30 \\
\hline
\end{tabular}

(*) Excluding operator and fuel.

(+) Based on Wholesale Price Index for Item 151102, motor trucks of 150.2

(f) Based on Wholesale Price Index for Item 1412, motor vehicle parts, of 170.3.

TABLE B-10. Indexes Used to Update Truck Transport Cost Data to May 1977

Index

WPI I tem 1412 - Motor Vehicle Parts

WPI Item 141102 - Motor Trucks

WPI Item 114 - General Purpose Machinery and Equipment

ENR Construction cost Index
May 1977 Value

193.3

173.6

200.2

2515 


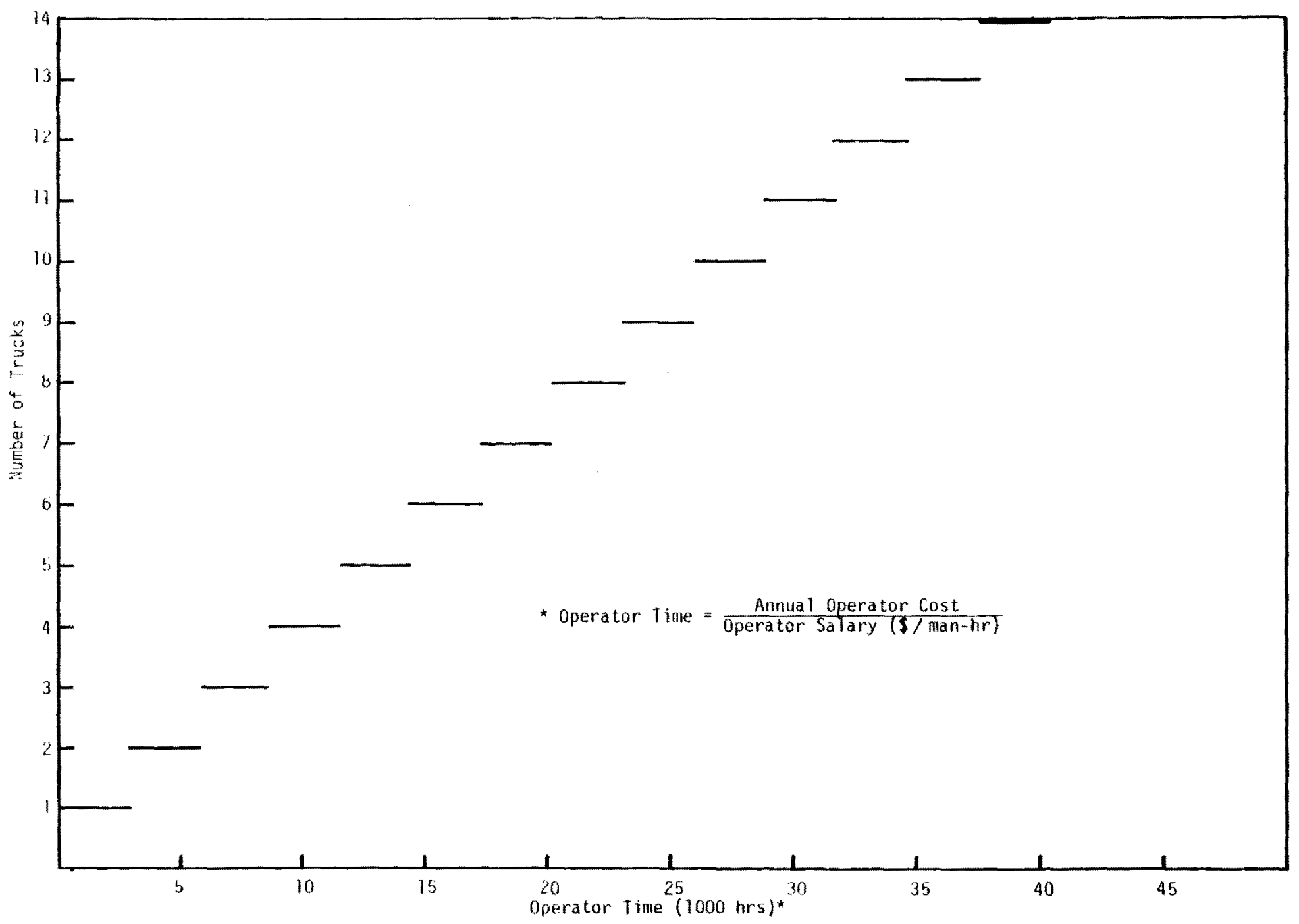

FIGURE B-73. Number of Trucks Required to Transport Sludge (360 days/yr, $8 \mathrm{hr} /$ day operation) 


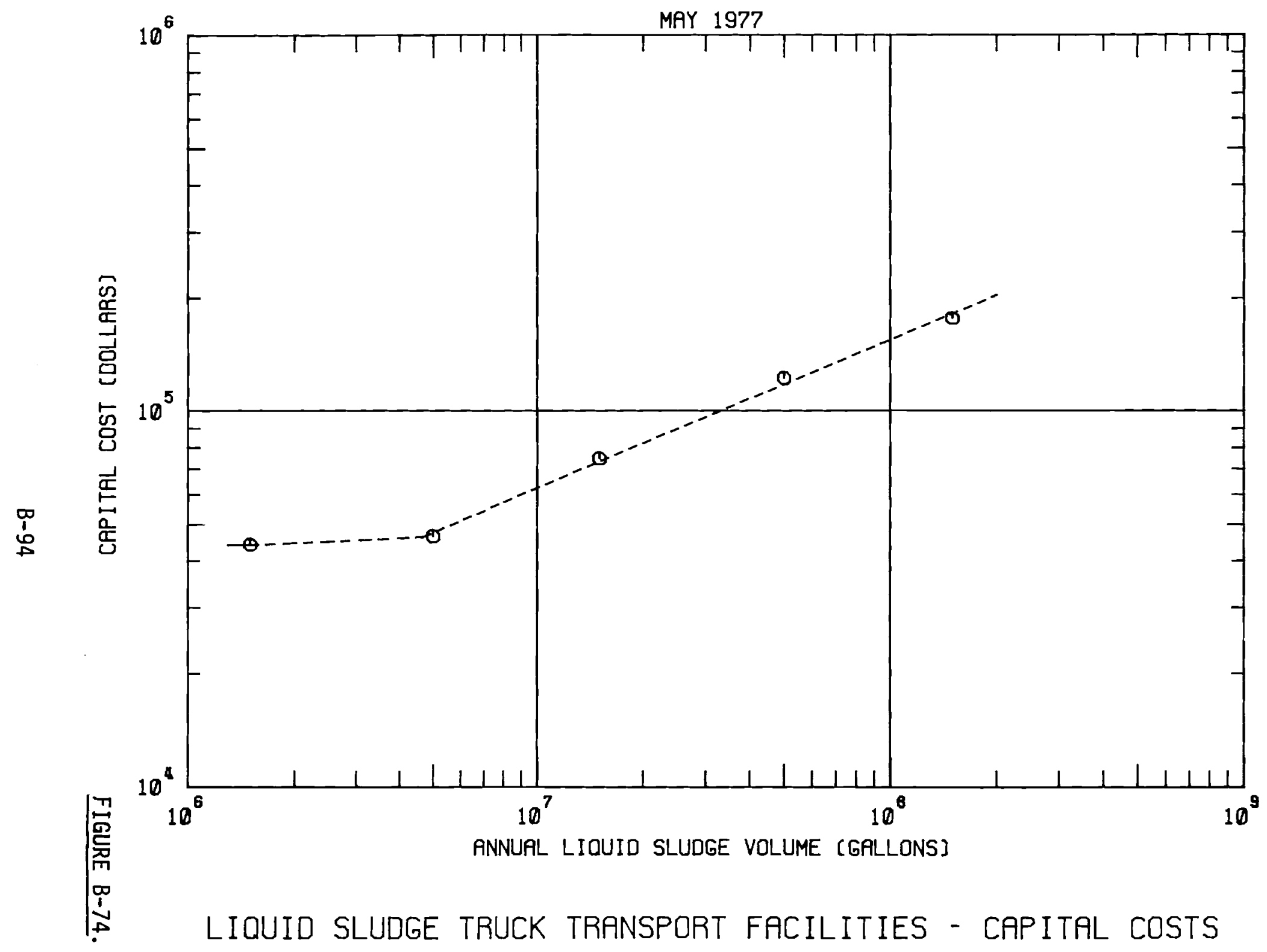




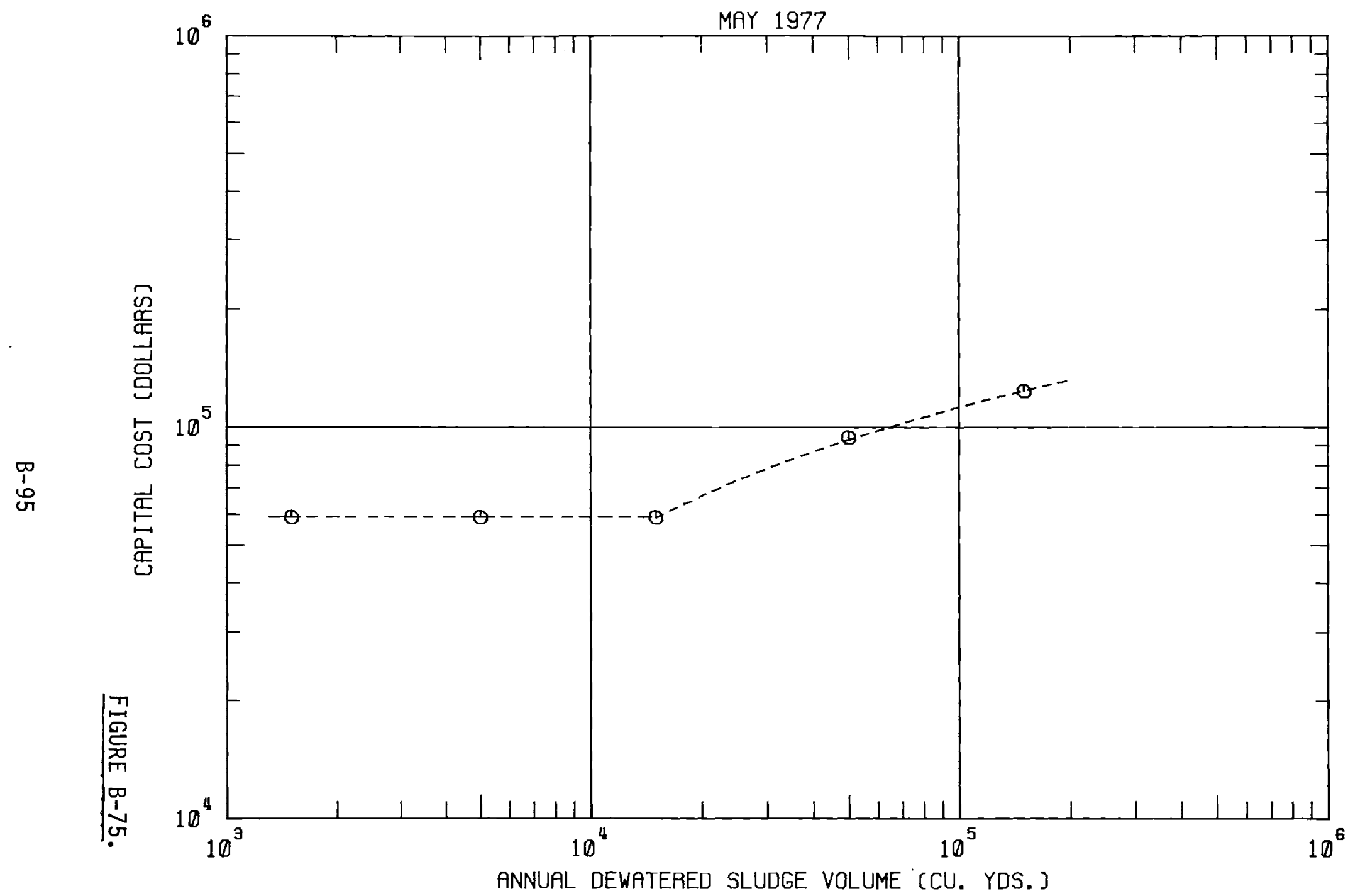

DEWATERED SLUDGE TRUCK TRANSPORT FACILITIES - CAPITAL COST 


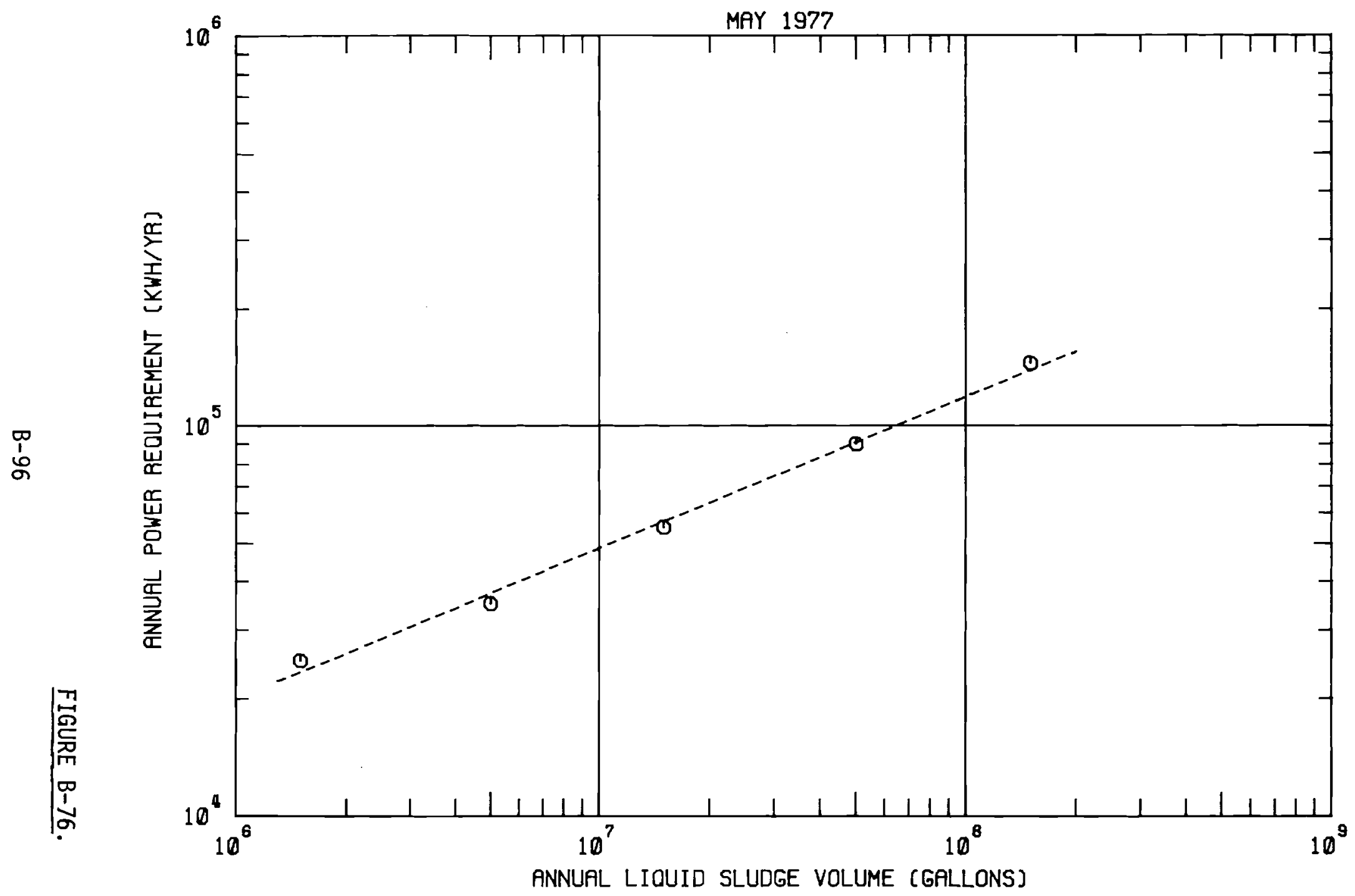

LIOUID SLUDGE TRUCK TRANSPORT FACILITIES

- POWER REQUIREMENTS 


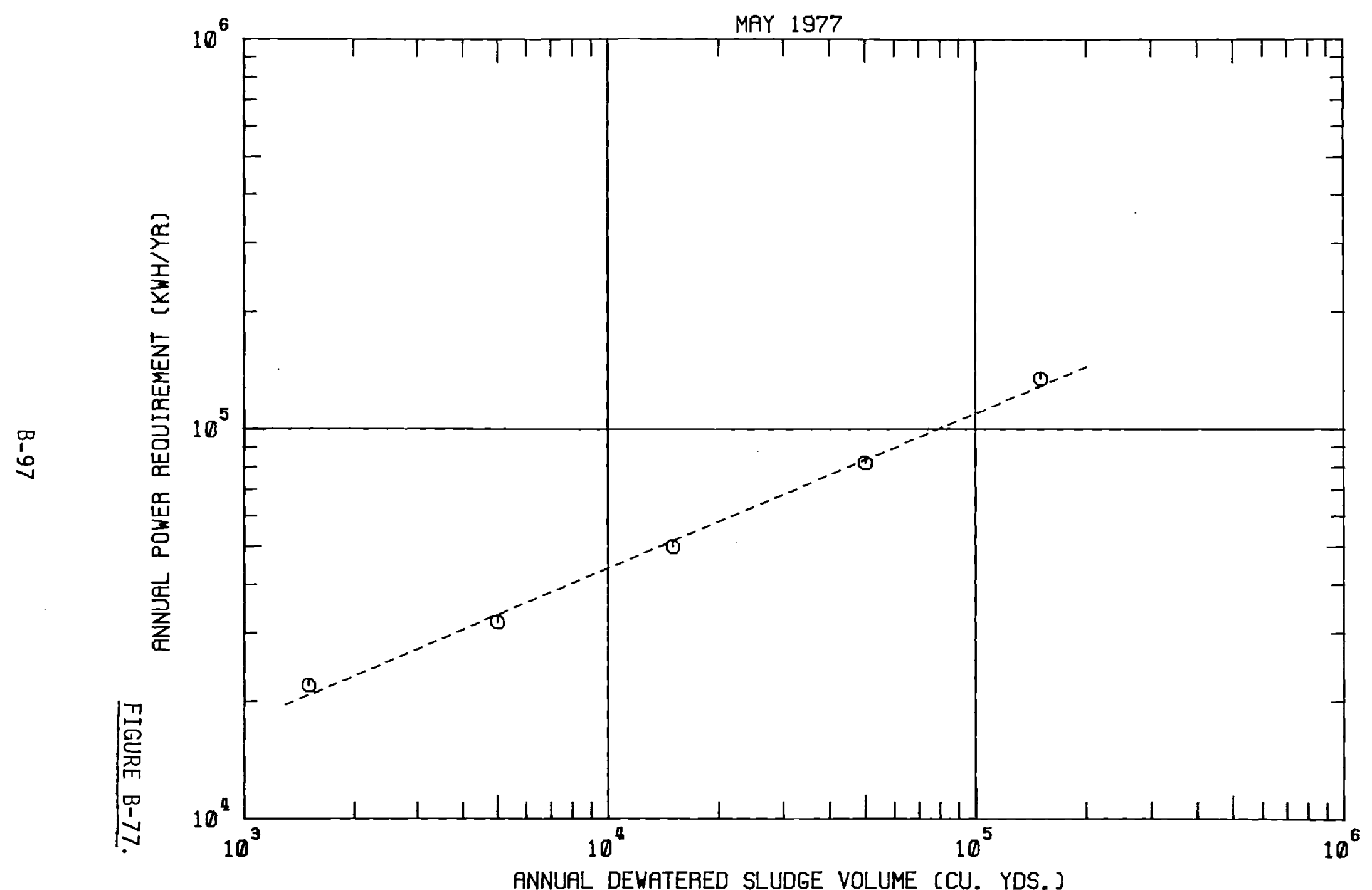

DEWATERED SLUDGE TRUCK TRANSPORT FACILITIES - POWER REQUIREMENTS 


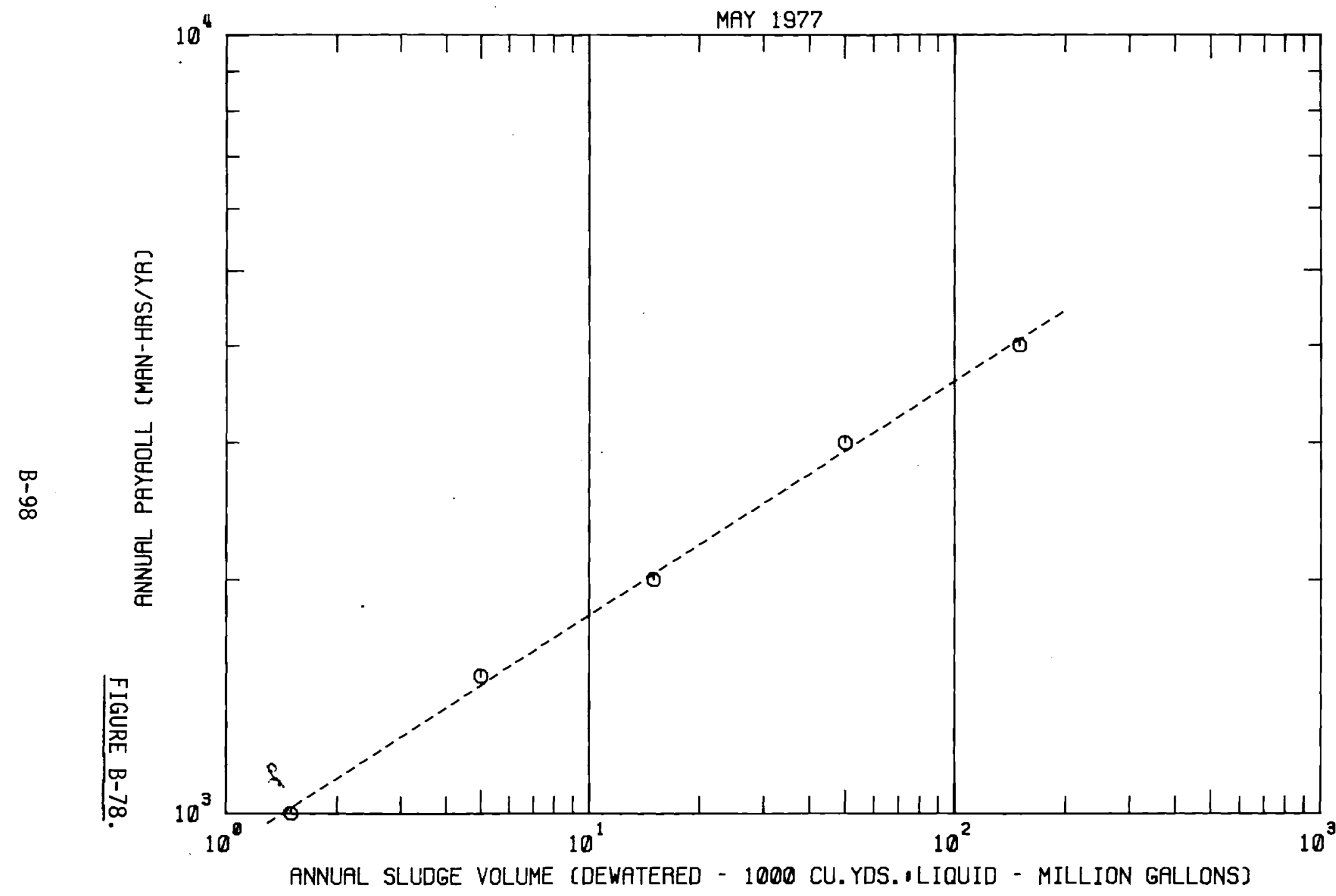

\section{LIOUID AND DEWATERED SLUDGE TRUCK TRANSPORT FACILITIES - LABOR REQUIREMENTS}




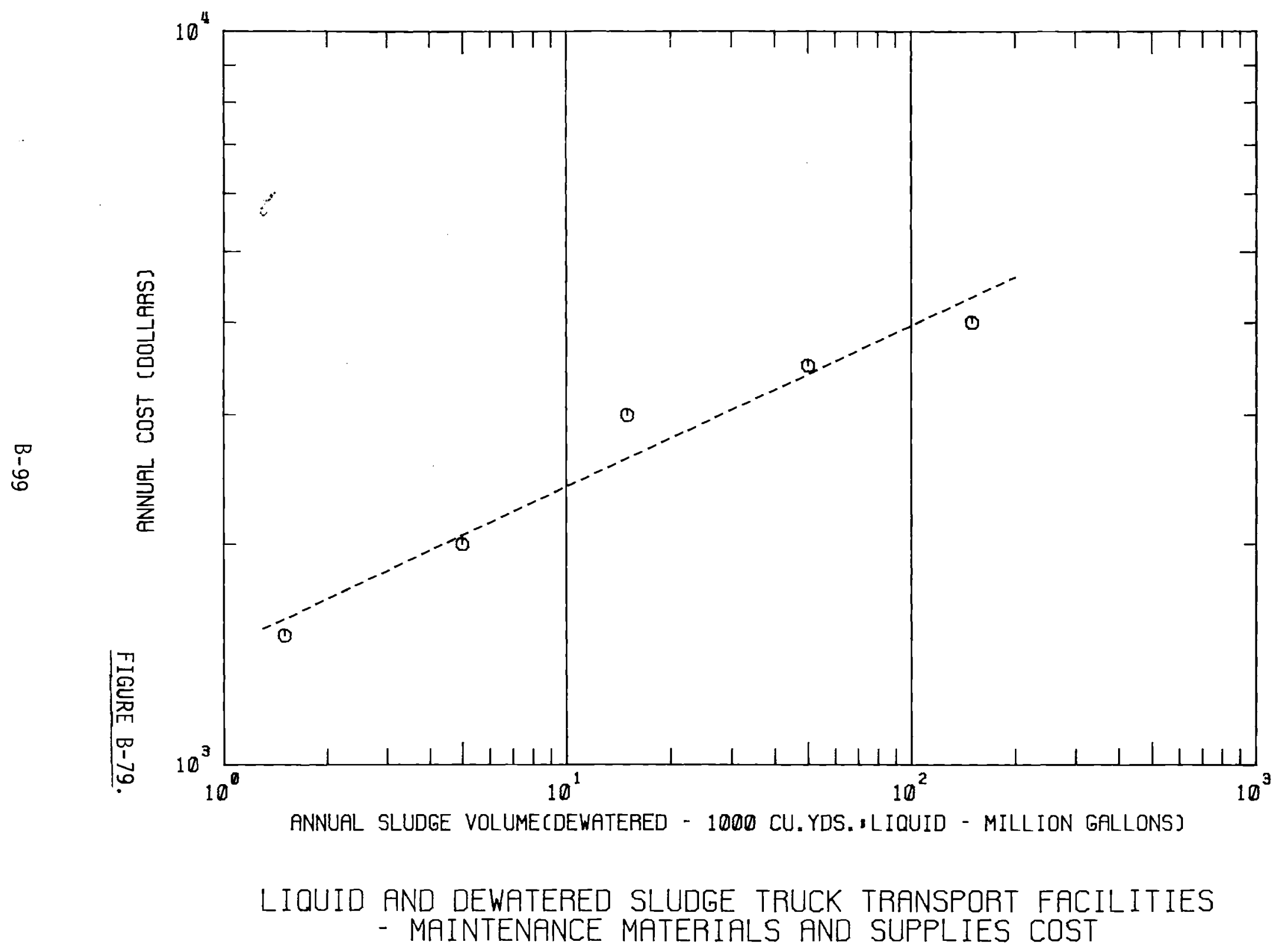


TABLE B-11. Estimated On-Site Costs for Land Disposal of Sludge (Source: Reference 8)

Method

Land spreading by truck or tractor of dewatered sludge cakes

10 dry tons/day

100 dry tons/day

Soil injection of liquid sludge
$\$ /$ Ton Dry Solids

2.50

1.70

5.90 
1. J. B. Farre1, J. E. Smith, Jr., S. W. Hathaway, and R. B. Dean, "Lime Stabilization of Primary Sludges," Journal Water Pollution Control Federation. 46(1):113-122, January 1974 .

2. C. A. Counts and A. J. Shuckrow, Lime Stabilized Sludge: Its Stability and Effect on Agricultural Land. Report to U.S. Environmental Protection Agency prepared by Battelle, Pacific Northwest Laboratories, Richland, WA 99352, November 1974.

3. R. T. Haug, L. D. Tortorrci, and S. K. Raksit, Sludge Processing and Disposal, A State of the Art Review. LA/OMA Project, Los Angeles/ Orange County Metropolitan Area, Whittier, CA 90607 , Apri1 1977.

4. Gainesville Compost Plant; Final Report on a Solid Waste Management Demonstration. Vo1. 1 \& 2, PB 222 710. Prepared for U.S. Environmental Protection Agency by Gainesville Municipal Waste Conversion Authority, Inc., Gainesville, FL 32601, 1973.

5. E. Epstein et al., "A Forced Aeration System for Composting Wastewater Sludge," J. Water Pollution Control Federation. 48(4):688-694, Apri1 $197 \overline{6 .}$

6. G. Stern, "Pasteurization of Liquid Digested Sludge," Proceedings of the National Conference on Municipal Sludge Management. Pittsburgh, PA, 1974.

7. Sludge Handling and Disposal - Phase I - State-of-the-Art. Prepared by Stanley Consultants, Inc. for the Metropolitan Sewer Board, St. Paul, MN 55101, November 15, 1972.

8. Estimated Costs of the B.E.S.T. System and Other Methods for Treatment and Use or Disposal of Municipal Wastewater Sludges. Prepared for Resources Conservation Company by Culp/Wesner/Culp, Clean Water Consultants, El Dorado Hi11s, CA 95630, January 1977.

9. W. F. Garber et a1., "Thermophilic Digestion at the Hyperion Treatment Plant," J. Water Pollution Control Federation. 47(5):950-961, May 1975.

10. G. L. Culp and D. J. Hinrichs, Municipal Wastewater Sludge Management Alternatives. Prepared for the Environmental Protection Agency Technology Transfer National Conference on 208 Planning and Implementation by Clean Water Consultants, El Dorado Hills, CA 95630.

11. Costs of Chemical Clarification of Wastewater. Draft Report to the EPA by Culp/Wesner/Culp, Clean Water Consultants, El Dorado Hi11s, CA 95630 , January 1976. 
12. Multiple Hearth Incineration. Zimpro, Inc., Golden, CO 80401, 1976.

13. D. Colacicco, E. Epstein et al., Costs of Sludge Composting. ARS-NE-79, Agricultural Research Service, U.S. Department of Agriculture, Beltsville, MD 20705, February 1977.

14. W. L. Patterson et al., Estimating Costs and Manpower Requirements for Conventional Wastewater Treatment Facilities. PB 217 132. Prepared for the EPA by Black and Veatch, Consulting Engineers, Kansas City, M0, October 1971.

15. Water Pollution Abatement Technology: Capabilities and Cost. PB 250690. Prepared for National Commission on Water Quality by Metcalf and Eddy, Inc., Boston, MA 02114, March 1976.

16. H. G. Blecker and T. M. Nichols, Capital and Operating Costs of Pollution Control Equipment Modules, Vol. II - Data Manual. PB 224536 , U.S. Environmental Protection Agency, Washington, DC 20460, July 1973. 


\section{DISTRIBUTION}

No. of

Copies

OFFSITE

A. A. Churm

Chicago Patent Group

Energy Research and

Development Administration

9800 South Cass Avenue

Argonne, IL 60439

27 DOE Technical Information Center

E. J. Wahlquist

Deputy Assistant Director

Terrestrial Programs

Division of Nuclear Research and Application

DOE

Washington, DC 20545

75 W. C. Remini

Division of Nuclear Research

DOE and Application

Washington, DC 20545

M. E. Morris

Sandia Laboratories

P.0. Box 5800

Albuquerque, NM 87115

50 H. D. Sivinski

Sandia Laboratories

P.0. Box 5800

Albuquerque, NM 87115

3 R. S. Stone

Arthur D. Little, Inc.

Acorn Park

Cambridge, MA 02140

J. J. Bzura

Arthur D. Little, Inc.

Acorn Park

Cambridge, MA 02140
No. of

Copies

Pio Lombardo

Pio Lombardo and Associates

24 Greenwich Park

Boston, MA 02118

R. I. Dick

School of Civil and

Environmental Engineering

Cornell University

Ithaca, NY 14850

10 G. Stern

EPA

Water Quality Office

Robert A. Taft Research

Center

4676 Columbia Parkway

Cincinnati, $\mathrm{OH} 45226$

J. Farrel

EPA

Water Quality Office

Robert A. Taft Research

Center

4676 Columbia Parkway

Cincinnati, OH 45226

W. W. Eckenfelder, Jr.

Distinguished Professor of

Environmental Engineering

Box 6222 Station B

Vanderbilt University

Nashville, TN 37235

R. H. Gurske

VTN Colorado, Inc.

2600 South Parker Road

Denver, CO 80232

F. L. Parker

Professor of Environmental

Engineering

Vanderbilt University

Box 1596 Station B

Nashville, TN 37235 
No. of

Copies

E. L. Thackston

Professor of Environmental Engineering

Vanderbilt University

Box 133 Station B

Nashville, TN 37235

D. Walter

DOE

20 Massachusetts Ave.

Washington, DC 20001

G. W. Thomas, President

New Mexico State University

Box $3 Z$

Las Cruces, NM 88003

L. S. Pope

Dean of Agriculture

New Mexico State University

Box 3AG

Las Cruces, NM 88003

G. S. Smith

Professor of Animal Nutrition

New Mexico State University

Department of Animal Range and Wildlife Sciences

Las Cruces, NM 88003

B. McCaslin

Department of Agronomy

New Mexico State University

Box 30

Las Cruces, NM 88003

L. Merritt

Professor of Civil Engineering

Brigham Young University

Provo, UT 84602
No. of

Copies

ONS ITE

51 Battelle-Northwest

G. W. Dawson

H. E. McGuire (20)

S. B. Ahlstrom (20)

B. W. Mercer

W. E. Sande

J. H. Jarrett

R. R. Spencer

H. H. Van Tuyl

P. C. Walkup

J. A. McNeese

D. C. Christensen

A. C. Campbel 1

D. B. Cearlock

Technical Information (5)

Technical Publications 